


\title{
A reciclagem de resíduos sólidos urbanos: um olhar a partir de três estudos de casos
}

\author{
ADRIANA FONSECA BRAGA
}

Tese apresentada ao Programa de Pós Graduação em Saúde Global e Sustentabilidade para obtenção do título de Doutor em Ciências.

Área de Concentração: Saúde Global e Sustentabilidade

Orientadora: Prof $^{a}$ Dr $^{\mathrm{a}}$ Helena Ribeiro

Versão Corrigida

São Paulo

2018 
Autorizo a reprodução e divulgação total ou parcial deste trabalho, por qualquer meio convencional ou eletrônico para fins de estudo e pesquisa, desde que citada a fonte.

Catalogação da Publicação Ficha elaborada pelo Sistema de Geração Automática a partir de dados fornecidos pelo(a) autor(a) Bibliotecária da FSP/USP: Maria do Carmo Alvarez - CRB-8/4359

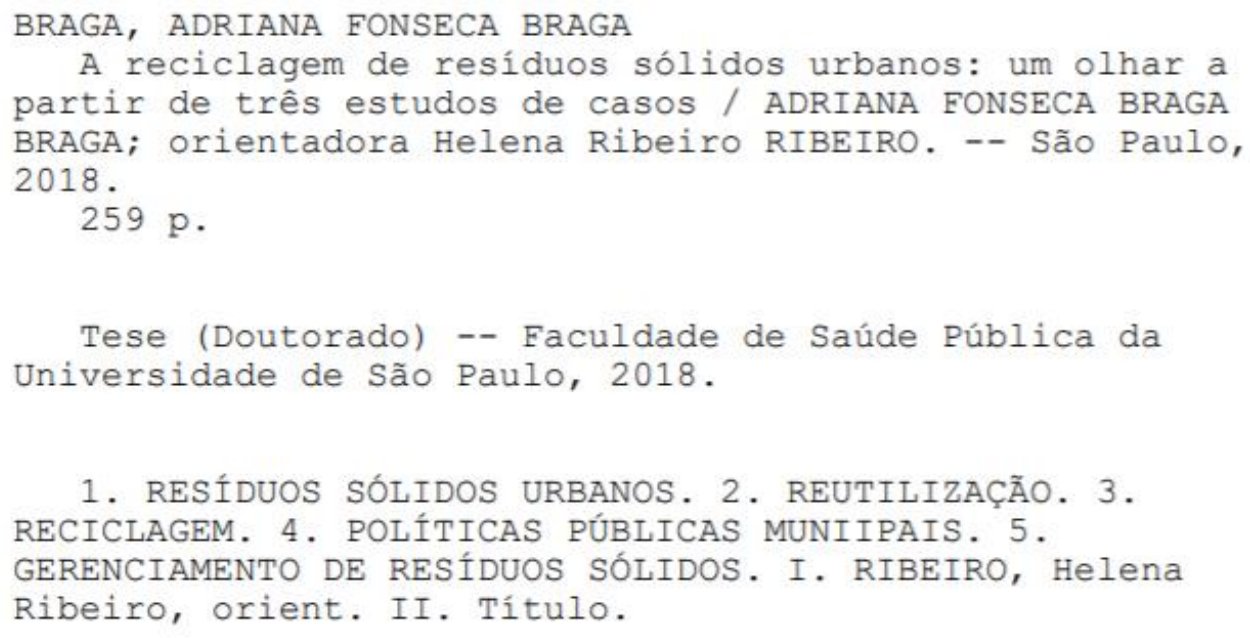




\section{DEDICATÓRIA}

Aos meus pais Vagner e Sonia.

A todos os amigos que fiz ao longo das minhas andanças profissionais e pessoais ao redor do mundo. 


\section{AGRADECIMENTOS}

Agradeço a minha querida professora e orientadora, Helena Ribeiro, que sempre acreditou na minha garra e abriu as portas do continente africano, por meio da vaga de Voluntário das Nações Unidas, há décadas atrás.

Ao meu pai, Vagner que sempre me apoiou em minha vida profissional. E a minha mãe que esteve ao meu lado, pedindo parcimônia na dedicação aos estudos.

Aos meus irmãos Anderson e Alessandro.

Aos meus sobrinhos Leonardo, Valentina e Davi que tiveram paciência em me esperar para brincar.

À Beatriz, minha parceira de viagens e que deixa minha vida mais feliz.

À Tata Mavilde que me acolheu em sua casa, na época da graduação e reconhece minha caminhada acadêmica.

À Vanessa e Greicy que me apoiaram durante minhas ausências nesta fase da vida.

À minha amiga irmã geógrafa, Keila que sempre disse que tudo ia dar certo.

Aos amigos que estiveram presentes em muitas fases da minha vida, antes de chegar aqui: Sarah e Lucia Juliane pelas noites de abrigo, Celso Ferrara, Adriana Furlan, Adriana Poço, Edil, Lili, Claudia, Filipe, Martines, Annamaria, Ricardo (turma da Tetra); Dumara e Sandra; Wandir Ribeiro, João Winther, Rodrigo Kato (velha guarda), Pedroso; Elder Lima; Magda Lara-Resende.

À Wanda que se revelou uma grande amiga, durante o processo do doutorado. Ao Ednilson pela oportunidade do estágio voluntário.

À Rizpah pelos bons papos e ótimos conselhos durante o processo desta pesquisa.

Aos colegas e amigos da FSP: Anne, Sofia, Sandra, Tiago, Marli, Rafael e Denise.

À Fundação CAPES pelo apoio na concessão de bolsa. 
Aos Departamentos de Meio Ambiente de São Francisco e de Resíduos Sólidos da Cidade do Cabo pela recepção durante os trabalhos de levantamento de campo e fornecimento de dados.

A AMLURB pelos dados fornecidos e recepção durante as entrevistas do levantamento de campo.

À turma da Secretaria da Pós Graduação da FSP, Vania e Carlos, que tem uma paciência ímpar com os alunos e sempre, muito atenciosos.

Aos membros da Banca de Qualificação e Defesa: Gina Rizpah Besen, Ednilson Viana, Wanda Maria Risso Günther.

E a todos que não pude mencionar aqui pois o espaço é restrito, o meu muito obrigada. 


\section{RESUMO}

BRAGA, A.F.. A reciclagem dos resíduos sólidos urbanos: um olhar a partir de três estudos de caso. [tese de doutorado]. São Paulo: Faculdade de Saúde Pública da USP; 2018.

Em muitas cidades ao redor do mundo, principalmente nos países em desenvolvimento, a gestão e o gerenciamento dos resíduos sólidos urbanos são inadequados e causam impactos negativos à saúde pública, meio ambiente, acentuam as desigualdades sociais e contribuem significativamente com a geração dos Gases do Efeito Estufa. Entretanto estes impactos negativos podem ser minimizados com o cumprimento de políticas públicas que promovem a reutilização e reciclagem desses resíduos. Esta pesquisa teve como objetivo identificar políticas públicas municipais que contribuem para o aumento das taxas de reciclagem de resíduos sólidos urbanos por meio de estudo de caso múltiplo comparativo entre três municípios: São Paulo (Brasil), Cidade do Cabo (África do Sul) e São Francisco (Estados Unidos). A metodologia baseou-se em referências bibliográficas para a identificação de um município que fosse referência mundial no tema e dois outros, situados em países em desenvolvimento (BRICS). Posteriormente foram realizados levantamentos de campo nos municípios selecionados por meio de roteiro de entrevistas e visitas técnicas e, na sequência, criados critérios de avaliação comparativa, baseados em cinco variáveis para a coleta com segregação na fonte e cinco variáveis para as políticas públicas. Os resultados apontaram que São Francisco recupera $84 \%$ dos resíduos, obtendo a melhor nota da avaliação, tanto em termos de variáveis técnicas da coleta, como em termos de políticas públicas implantadas. A Cidade do Cabo recupera $27 \%$ dos resíduos e obteve a segunda melhor avaliação e, São Paulo que recupera 1,62\% dos resíduos, obteve a menor avaliação. As conclusões apontaram que para se alcançar maiores taxas de reciclagem de resíduos sólidos urbanos é fundamental: a obrigatoriedade local de segregação dos resíduos na fonte geradora, a cobrança dos serviços de coleta seletiva para garantir a sustentabilidade 
econômica, incluindo sistema que permita o pagamento de taxa proporcional às quantidades de resíduos geradas, ampliar programas complementares de minimização de resíduos, campanhas em massa para divulgação dos serviços de coleta seletiva, assim como, a execução de planos integrados de resíduos sólidos com objetivos, metas, recursos e cronograma executivo adaptados às realidades locais dos municípios, inclusive com participação de prestadores de serviços diversificados como o terceiro setor e empresas privadas de diversos porte.

Palavras-chave: resíduos sólidos urbanos; reutilização; reciclagem; políticas públicas municipais; gerenciamento de resíduos sólidos urbanos. 


\begin{abstract}
BRAGA, A.F.. The recycling of municipality solid waste: a look from three case studies. [doctoral thesis]. São Paulo. São Paulo: School of Public Health of USP; 2018.

In many cities around the world, especially in developing countries, the management of municipal solid waste is inadequate and contributes with to negative impacts for public health and the environment, accentuates social inequalities and contributes significantly to the generation of Greenhouse Gases. However, these negatives impacts can be minimized by complying public policies that promote the reuse and recycling of municipality solid waste. The objective of this research was to identify local public policies that contribute to increase the rates of municipal solid waste recycling through a comparative multiple case studies of three cities: São Paulo (Brazil), Cape Town (South Africa) and San Francisco (The United States). The methodology was based on bibliographical references for the identification of a city that is a world reference in the theme and two others, located developing countries (BRICS). Afterwards field surveys were carried out in the selected municipalities through a script of interviews and technical visits, followed by benchmarking criteria based on five variables for collection with segregation at source and five variables for public policies. The results showed that São Francisco recovers $84 \%$ of the waste, obtaining the best evaluation score, both in terms of technical variables of collection and in terms of public policies implemented. Cape Town recovers 27\% of the waste and obtained the second best evaluation, and São Paulo, which recovers $1.62 \%$ of the waste, obtained the lowest evaluation. The conclusions pointed out that in order to achieve high rates of recycling of solid urban waste, it is essential to: local compulsory segregation of waste in the generating source, the charging of collection services to ensure financial sustainability, including a system that allows the payment of a fee proportional to the amount of waste generated, mass campaigns to disseminate selective waste collection services, as well as the implementation of integrated solid waste plans with objectives, targets, resources and executive schedule adapted to the local realities of municipalities, including the participation of diversified service providers such as the third sector and private companies of various sizes.
\end{abstract}

Keywords: municipal solid waste; reuse; recycling; municipal public policies; solid waste management. 


\section{ÍNDICE}

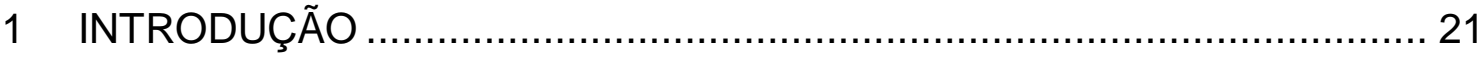

2 IMPACTOS À SAÚDE E AO MEIO AMBIENTE DO GERENCIAMENTO INADEQUADO DE RESÍDUOS SÓLIDOS URBANOS E AÇÕES DE

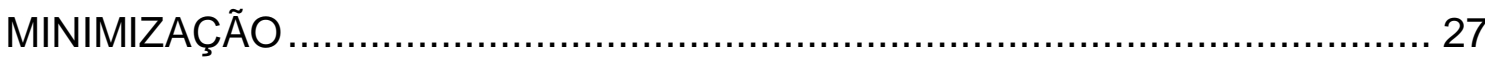

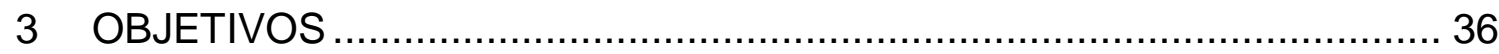

4 REFERENCIAIS TEÓRICOS ............................................................. 37

4.1 BENEFÍCIOS DA REUTILIZAÇÃO E RECICLAGEM DE RESÍDUOS SÓLIDOS URBANOS ......37

4.2 ESTUDO REFERENCIAL DE GERENCIAMENTO DE RESÍDUOS SÓLIDOS URBANOS .........41

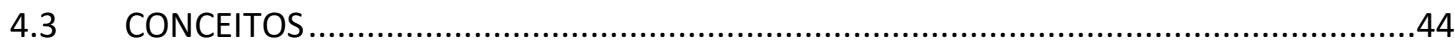

4.4 RESÍDUOS SÓLIDOS URBANOS, COLETA SELETIVA, REUTILIZAÇÃO E RECICLAGEM NO

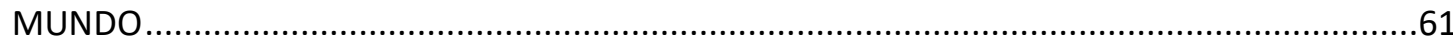

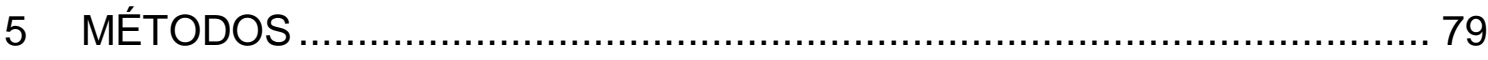

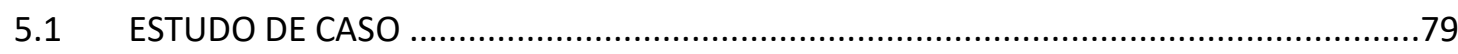

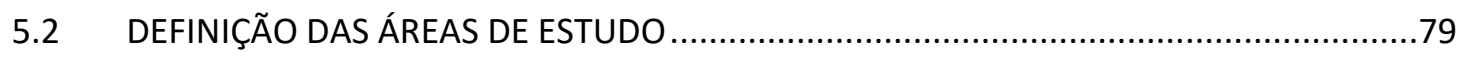

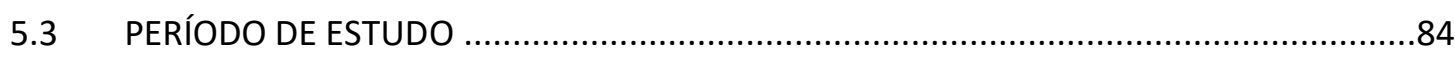

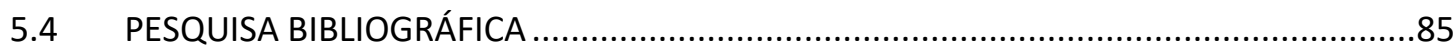

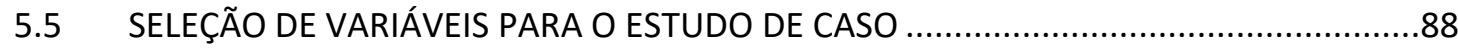

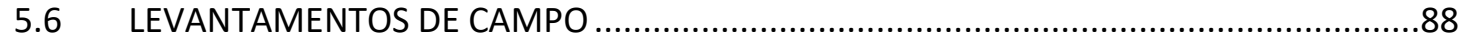

5.7 COMPARAÇÃO E AVALIAÇÃO DOS ESTUDOS DE CASO …...........................................

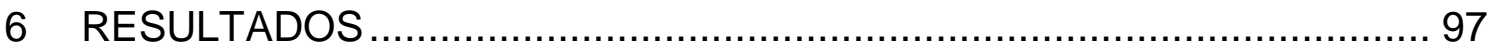

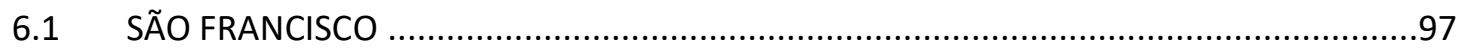

6.1.1 História e Tradição da Reciclagem em São Francisco ........................................99

6.1.2 Gerenciamento dos Resíduos Sólidos Urbanos de São Francisco .......................102

6.1.3 Recuperação de custos dos serviços de coleta de resíduos...............................116

6.1.4 Programas de Minimização de Resíduos ...........................................................116

6.1.5 Políticas Públicas Aplicadas aos Resíduos Sólidos em São Francisco .................120

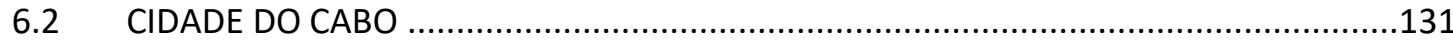




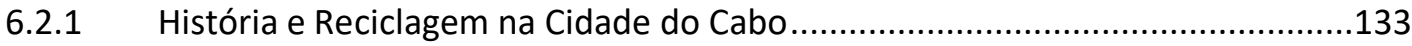

6.2.2 Gerenciamento dos Resíduos Sólidos Urbanos na Cidade do Cabo....................134

6.2.3 Recuperação de custos dos serviços de coleta de resíduos ...............................140

6.2.4 Programas de Minimização de Resíduos da Cidade do Cabo.............................140

6.2.5 Políticas Públicas Aplicadas aos Resíduos Sólidos na Cidade do Cabo ................150

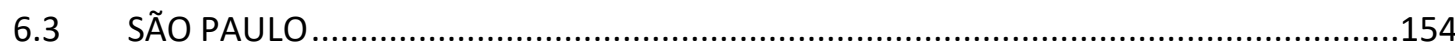

6.3.1 História e Tradição da Reciclagem em São Paulo ................................................156

6.3.2 Gerenciamento dos Resíduos Sólidos Urbanos de São Paulo ............................157

6.3.3 Recuperação de custos dos serviços de coleta regular e/ou seletiva .................176

6.3.4 Programas de Minimização de Resíduos Dispostos em Aterros em São Paulo..176

6.3.5 Políticas Públicas Aplicadas aos Resíduos Sólidos de São Paulo .........................181

7 COMPARAÇÃO E DISCUSSÃO DOS CASOS ESTUDADOS ................ 184

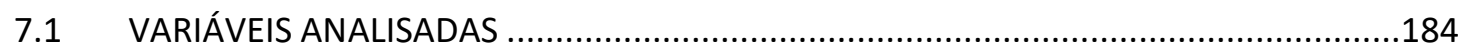

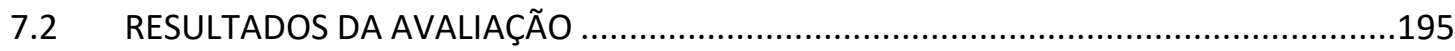

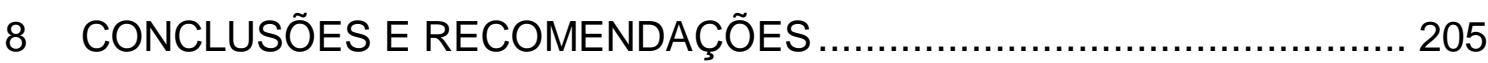

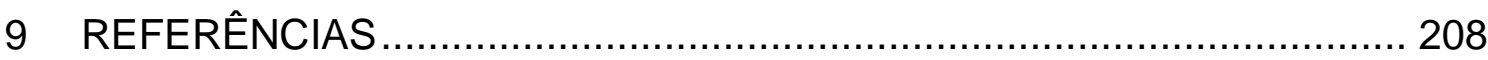

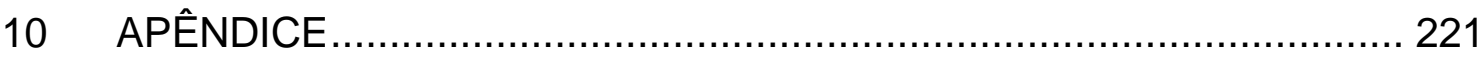

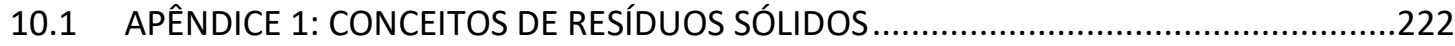

10.2 APÊNDICE 2: CONTATOS REALIZADOS COM INSTITUIÇÕES DE RESÍDUOS SÓLIDOS NOS

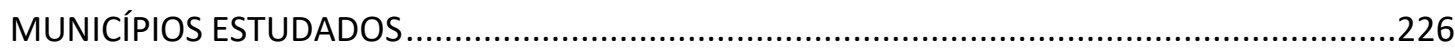

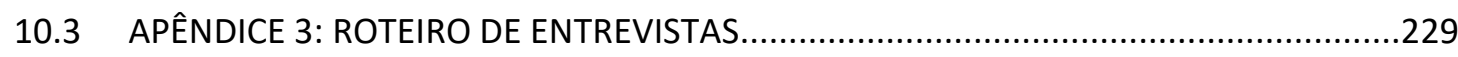

10.4 APÊNDICE 4: DATAS DOS LEVANTAMENTOS DE CAMPO POR MUNICÍPIO ................239

10.5 APÊNDICE 5: TRABALHO PUBLICADO EM CONGRESSO INTERNACIONAL DE RESÍDUOS

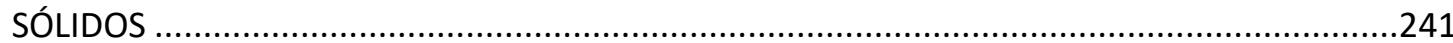

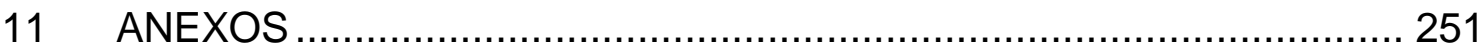

11.1 CARACTERIZAÇÃO GRAVIMÉTRICA DOS RESÍDUOS EM SÃO PAULO ...........................252

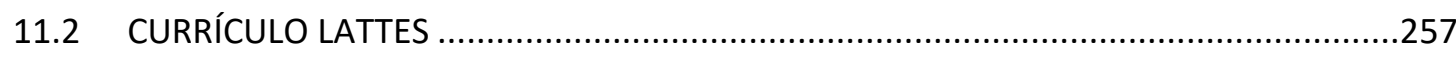




\section{LISTA DE ABREVIATURAS}

\begin{tabular}{|c|c|}
\hline AMLURB & Autoridade Municipal de Limpeza Urbana \\
\hline BRICS & Brasil, Rússia, Índica, China, África do Sul \\
\hline CCAC & Coalisão para o Clima e Ar Limpo \\
\hline COP 21 & Convenção Quadro das Nações Unidas sobre Mudança do Clima \\
\hline EE & Efeito Estufa \\
\hline EEA & Agência Ambiental Europeia \\
\hline ERP & Responsabilidade Estendida do Produtor \\
\hline FUNASA & Fundação Nacional de Saúde \\
\hline GEE & Gases do Efeito Estufa \\
\hline GSIR & Gerenciamento Sustentável Integrado de Resíduos \\
\hline HABITAT & Programa das Nações Unidas para os Assentamentos Humanos \\
\hline IPCC & Painel Intergovernamental de Mudanças Climáticas \\
\hline ISWA & Associação Internacional de Resíduos Sólidos \\
\hline OCDE & Organização de Cooperação e de Desenvolvimento Económico \\
\hline ODS & Objetivos de Desenvolvimento Sustentável \\
\hline ONG & Organização Não Governamental \\
\hline PGIRS & Plano de Gerenciamento Integrado de Resíduos Sólidos de São Paulo \\
\hline PNRS & Política Nacional de Resíduos Sólidos do Brasil \\
\hline PRODAM & $\begin{array}{l}\text { Empresa de Tecnologia da Informação e Comunicação do Município de São } \\
\text { Paulo }\end{array}$ \\
\hline RSU & Resíduos Sólidos Urbanos \\
\hline SABESP & Companhia de Saneamento Básico do Estado de São Paulo \\
\hline SINIS & Sistema Nacional de Informações em Saneamento \\
\hline SISCOR & Sistema de Controle de Resíduos Sólidos Urbanos \\
\hline SISNAMA & Sistema Nacional de Meio Ambiente \\
\hline SNVS & Sistema Nacional de Vigilância Sanitária \\
\hline SUASA & Sistema Unificado de Atenção à Sanidade Agropecuária \\
\hline UN & Nações Unidas \\
\hline UNITAST & Divisão de Estatísticas das Nações Unidas \\
\hline USEPA & Agência de Proteção Ambiental Americana \\
\hline
\end{tabular}




\section{LISTA DE TABELAS}

Tabela 1 Gasto de energia elétrica na produção de bens de consumo com matéria prima e com uso resíduo sólido, Canadá, 2005

Tabela 2 Quantidade de material recuperada, GEE emitidos a partir do uso de materiais recuperados e equivalência do número de automóveis retirados de estradas estimados pela USEPA nos Estados Unidos, 2013

Tabela 3 Percentual de resíduos sólidos urbanos reciclados nos Estados Unidos, entre 1960 e 2013

Tabela 4 Reciclagem de resíduos sólidos urbanos em países do continente africano, em 2011

Tabela 5 Quantidade de resíduos sólidos coletadas no Brasil, de 2006 a 2016

Tabela 6 Quantidade de resíduos sólidos recolhidos por coletadas seletivas no Brasil de 2006 a 2016

Tabela 7 Caracterização de São Francisco, nos anos de 2000, 2010 e 2015

Tabela 8 Quantidades totais de resíduos sólidos gerados, aterrados e desviados de aterros sanitários para São Francisco, entre 2003 e 2006

Tabela 9 Quantidades totais de resíduos sólidos gerados, recuperados, em São Francisco, entre 2006 e 2014

Tabela 10 Estimativa de resíduos sólidos domiciliares produzidos São Francisco, em toneladas, entre 2006 e 2014

Tabela 11 Tipos de resíduos recebidos pela Recology, desviados do aterramento, disposto em aterro e taxa de desvio entre 1 de julho de 2014 a 30 de junho de 2016, São Francisco

Tabela 12 Composição gravimétrica dos resíduos sólidos urbanos recebidos no aterro Norcal provenientes da coleta de resíduos sólidos urbanos de São Francisco em 2006

Tabela 13 Caracterização da Cidade do Cabo nos anos de 2011 e 2016 
Tabela 14 Quantidades de resíduos sólidos urbanos coletados na Cidade do Cabo, por tipo, entre 2007 e 2016

Tabela 15 Composição gravimétrica dos resíduos sólidos urbanos recebidos nos aterros da Cidade do Cabo, em 2011

Tabela 16 Unidades de recepção, tratamento e/ou disposição final da Cidade do Cabo, por tipo de resíduos, em 2018

Tabela 17 Caracterização de São Paulo nos anos de 2010 e 2015

Tabela 18 Total de resíduos sólidos urbanos, domiciliares e da coleta seletiva entre 2006 e 2016 para São Paulo

Tabela 19 Composição gravimétrica média dos resíduos sólidos urbanos domiciliares de São Paulo de março a setembro de 2015

Tabela 20 Taxa de coleta seletiva em relação ao total de resíduos sólidos domiciliares por Prefeitura Regional entre 2006 e 2016 para São Paulo

Tabela 21 Tipos de coleta seletiva de resíduos sólidos domiciliares em São Paulo em 2016

Tabela 22 População e renda per capita nos municípios estudados

Tabela 23 Total de resíduos sólidos urbanos e taxa de coleta seletiva

Tabela 24 Avaliação da coleta de resíduos sólidos urbanos com segregação na fonte geradora para os municípios estudados

Tabela 25 Avaliação das políticas públicas de resíduos sólidos urbanos para os três municípios estudados 


\section{LISTA DE QUADROS}

Quadro 1 Porcentagem de energia gasta no processo produtivo com materiais recicláveis em relação a matéria prima

Quadro 2 Linhas de análise do estudo comparativo

Quadro 3 Benchmark no estudo comparativo

Quadro 4 Tipificação de resíduos e respectivas normativas em São Francisco, Estados Unidos

Quadro 5 Tipificação de resíduos gerados e respectivas normativas na Cidade do Cabo, África do Sul

Quadro 6 Serviços divisíveis e lei municipal correspondente, por tipo de resíduo gerados e coletados, em São Paulo, Brasil

Quadro 7 Princípios básicos do gerenciamento sustentável integrado de resíduos (GSIR)

Quadro 8 Municípios pré-selecionados para definição da área de estudo

Quadro 9 Matriz de Elegibilidade de municípios a serem estudadas nos BRICS

Quadro 10 Critério de avaliação das variáveis para a coleta de resíduos sólidos com segregação na fonte geradora

Quadro 11 Critério de avaliação de políticas públicas e instrumentos legais

Quadro 12 Categorias de separação dos resíduos sólidos urbanos, categorias em São Francisco, Estados Unidos

Quadro 13 Composição dos resíduos por categorias de separação, em São Francisco, Estados Unidos

Quadro 14 Unidades receptoras de RSU de São Francisco em 2018, Estados Unidos

Quadro 15 Programas complementares de minimização de resíduos sólidos urbanos de São Francisco 
Quadro 16 Políticas públicas e seus instrumentos para a gestão dos resíduos sólidos em São Francisco, de 2002 a 2016

Quadro 17 Variáveis demográficas da Cidade do Cabo, em 2011

Quadro 18 Bairros de Cidade do Cabo abrangidos pelo Programa Think Twice.

Quadro 19 Políticas públicas e seus instrumentos para a gestão dos resíduos sólidos da Cidade do Cabo, 2018

Quadro 20 Variáveis demográficas de São Paulo em 2010

Quadro 21 Serviços de limpeza urbana de resíduos sólidos em São Paulo, 2013

Quadro 22 Categorias de separação dos resíduos sólidos urbanos de São Paulo

Quadro 23 Ranking de coleta de resíduos sólidos domiciliares por Prefeituras Regionais de São Paulo, Brasil, em 2016

Quadro 24 Unidades de recepção, triagem e tratamento de resíduos sólidos urbanos em operação em São Paulo, 2017

Quadro 25 Políticas públicas e seus instrumentos para a gestão dos resíduos sólidos de São Paulo, 2018

Quadro 26 Metas previstas e realizadas do PGIRS para São Paulo, abril 2018

Quadro 27 Comparação das variáveis da coleta seletiva nos municípios estudados

Quadro 28 Comparação das variáveis de políticas públicas nos municípios estudados

Quadro 29 Resultado final da avaliação da coleta seletiva e políticas públicas para os municípios estudados 


\section{LISTA DE FIGURAS}

Figura 1 Etapas do sistema de gerenciamento de resíduos sólidos urbanos Figura 2 Inter-relação do sistema de gerenciamento de resíduos sólidos urbanos com outros sistemas municipais

Figura 3 Dimensões do modelo gerenciamento sustentável integrado de resíduos sólidos

Figura 4 Foco da investigação da pesquisa no sistema de gerenciamento de resíduos sólidos urbanos

Figura 5 Reciclagem de resíduos sólidos urbanos no mundo, em 2011

Figura 6 Composição dos resíduos sólidos urbanos nos Estados Unidos em 2013

Figura 7 Hierarquia do gerenciamento dos resíduos sólidos nos Estados Unidos, em 2013

Figura 8 Taxas de reciclagem de resíduos sólidos urbanos reciclados nos Estados Unidos, entre 1960 e 2013

Figura 9 Hierarquia de resíduos da União Europeia

Figura 10 Taxa regional de reciclagem de resíduos sólidos urbanos em 2008/2009 na Europa

Figura 11 Taxa de reciclagem de resíduos sólidos urbanos reciclados em 32 países europeus, em 2001 e 2010 (\%)

Figura 12 Composição dos resíduos sólidos urbanos na África do Sul, em 2011

Figura 13 Localização dos municípios estudados

Figura 14 Vista geral de São Francisco, Califórnia, Estados Unidos

Figura 15 Localização geral de São Francisco, Califórnia, Estados Unidos

Figura 16 Coletores de resíduos sólidos urbanos com carroças em São Francisco na década de 1920 
Figura 17 Coleta de resíduos sólidos urbanos em caminhão em São Francisco na década de 1960

Figura 18: Contentores utilizados para separação dos resíduos sólidos urbanos em São Francisco

Figura 19: Contentores diferenciados para coleta de resíduos sólidos urbanos em residências em São Francisco

Figura 20 Fluxograma de origem e destino dos resíduos sólidos urbanos de São Francisco, 2016

Figura 21 Carretas de transbordo de materiais recicláveis e orgânicos que são enviados para porto para comercialização ou planta de compostagem. Pier 96

Figura 22 Área portuária de embarque de contêineres com materiais recicláveis secos prontos para comercialização

Figura 23 Central mecanizada de triagem de resíduos sólidos recicláveis/secos. Pier 96

Figura 24 Galpão de orgânicos que recebe materiais que são transportados por carretas para compostagem

Figura 25 Vista geral da unidade de compostagem de Jepson Prairie, 2016

Figura 26 Tipos de produtos comercializados a partir da produção de composto da Jepson Prairie, 2016

Figura 27 Local de recepção de resíduos eletrônicos. Pier 96

Figura 28 Local de recepção de materiais reaproveitáveis. Pier 96

Figura 29 Local de entrega voluntária de embalagens com produtos químicos para pequenos geradores. Pier 96.

Figura 30 Localização geral da Cidade do Cabo na África do Sul

Figura 31 Vista geral da Cidade do Cabo na África do Sul

Figura 32: contentor preto para resíduos do Programa Think Twice que são enviados para aterros sanitários 
Figura 33 Fluxograma da origem e destino dos resíduos sólidos urbanos domiciliares da Cidade do Cabo, 2018

Figura 34 Pequenas empresas cadastradas no Departamento de Resíduos Sólidos da Cidade do Cabo que executam a coleta e triagem de recicláveis do Programa Think Twice

Figura 35 Regiões abrangidas pelo Programa Think Twice e Drof Offs da Cidade do Cabo, 2018

Figura 36 Rampas de acesso para descarga de materiais recicláveis. Kraaifontein Drop Off.

Figura 37 Entrega de materiais recicláveis. Kraaifontein Drop Off. Rampas

Figura 38 Contentor para recepção de óleos lubrificantes usados. Muizenberg Drop Off.

Figura 39 Baias para armazenagem de resíduo eletrônico. Kraaifontein Drop Off.

Figura 40 Área de carregamento de poda para futuro transporte para unidade de compostagem. Muizenberg Drop Off

Figura 41 Escritório de empresa Reliance que comercializa o composto proveniente da compostagem de poda. Muizenberg Drop Off

Figura 42 Caminhão de empresa de pequeno porte que tria e comercializa os materiais recicláveis entregues pelos munícipes no Drop Off de Muizenberg

Figura 43 Modelo de composteira caseira distribuída gratuitamente pela administração municipal da Cidade de Cabo.

Figura 44 Fotografia enviada ao Departamento de Resíduos Sólidos por participante do Programa que utiliza o composto em sua propriedade

Figura 45 trailer do programa Swop Shop

Figura 46 cartão de débito kilorands card do programa Packa Ching

Figura 47 Trailer compactador do programa Packa Ching

Figura 48 Moradores na fila para a pesagem dos resíduos recicláveis do programa Packa Ching 
Figura 49 Localização geral do município de São Paulo, Brasil

Figura 50 Vista parcial da região central de São Paulo

Figura 51 Taxa de coleta seletiva domiciliar por Prefeitura Regional em São Paulo, 2016

Figura 52 Percentual dos tipos de coleta seletiva em 2016 para São Paulo

Figura 53 Tipo de coleta seletiva de resíduos domiciliares e entregues em PEV por Prefeitura Regional em São Paulo, 2016

Figura 54 Fluxograma da origem e destino dos resíduos sólidos de São Paulo, 2016

Figura 55 Posto de entrega voluntária de resíduos sólidos recicláveis/secos de São Paulo

Figura 56 Vista parcial da entrada de Ecoponto com sinalização dos materiais recebidos na unidade

Figura 57 Caminhão utilizado na operação cata bagulho

Figura 58 Vista parcial do pátio de compostagem da Lapa

Figura 59 Políticas públicas implantadas ao longo do tempo nos municípios estudados. 


\section{INTRODUÇÃO}

Os Resíduos Sólidos Urbanos (RSU) são gerados pelo ser humano em suas atividades diárias, como fazer refeições, organizar e limpar ambientes, atividades de trabalho, de estudo e de lazer, dentre outras. É uma geração ininterrupta e as quantidades, em nível mundial, aumentam ano após ano.

Segundo o Banco Mundial (2012), a geração mundial estimada de resíduos sólidos urbanos ${ }^{1}$ vem crescendo nos últimos anos, em percentuais superiores ao crescimento da população urbana (WORLD BANK, 2012): em 2002 foram estimados 0,68 bilhões de toneladas de resíduos, 1,3 bilhões de toneladas em 2012 e previu-se que em 2025 serão produzidas 2,2 bilhões de toneladas, ou seja, entre 2002 e 2012, um crescimento de $91 \%$ e entre 2012 e 2025, um crescimento de $69 \%$. Em contrapartida, as estimativas do Banco Mundial para a população urbana mundial foram de 2,9 bilhões de pessoas em 2002, 3 bilhões em 2012 e 4,3 bilhões em 2025, ou seja, entre 2002 e 2012, um crescimento de $3 \%$ e entre 2012 e 2025 , um crescimento de $43 \%$.

$O$ fato é que a gestão inadequada dos RSU, principalmente nos municípios de países em desenvolvimento, desencadeia impactos negativos à saúde e ao ambiente, acentua desigualdades sociais e econômicas e contribui significativamente para a geração dos gases do Efeito Estufa (GEE) (BESEN et.al., 2014; UN, 2014).

$\mathrm{Na}$ escala global, a organização das Nações Unidas reconhece a importância do tema gerenciamento dos resíduos sólidos urbanos e suas consequências para a saúde pública, qualidade de vida e meio ambiente, especialmente quando não há gerenciamento adequado conforme apontado no relatório "Solid Waste Management in The World's Cities" (UN HABITAT, 2010). Este relatório

\footnotetext{
${ }^{1}$ Definição de resíduos sólidos urbanos da Organização para a Cooperação e Desenvolvimento Económico (OECD): resíduos domésticos, incluindo resíduos volumosos, resíduos de comércio e outros negócios, edifícios de escritórios, instituições e empresas de pequeno porte, quintal e jardim, resíduos da varrição e das lixeiras das ruas e limpeza de mercados. São excluídos: resíduos de esgoto e seu tratamento e resíduos de demolição.
} 
aponta oito riscos evidentes para a saúde das populações quando os sistemas de RSU são mal geridos, o que se evidencia em países em desenvolvimento:

- As populações são expostas a mais riscos em países em desenvolvimento devido a presença de maior quantidade de matéria orgânica nos RSU que podem conter materiais em decomposição, contendo bactérias, elementos infecciosos e perigosos. A falta de padronização no acondicionamento e a irregularidade na coleta dos resíduos expõem as populações a maiores riscos;

- Trabalhadores dos setores de limpeza formal e informal também são mais expostos aos riscos porque, em muitos casos, as condições de higiene e do gerenciamento dos RSU são precárias;

- Os riscos para a população em geral estão diretamente associados ao acúmulo de resíduos sólidos nas ruas e terrenos baldios que propiciam o surgimento de hospedeiros com vetores transmissores de doenças;

- Os resíduos sólidos urbanos não coletados provocam obstrução de drenagens urbanas e naturais e, consequentemente, a estagnação de águas produz ambientes propícios para proliferação de mosquitos; contribuem para a contaminação das águas utilizadas para abastecimento humano e para a dessedentação animal. Especialmente nos países tropicais (altas temperaturas e grande umidade), a matéria orgânica tem seu processo de degradação mais acelerado, gerando chorume que afeta diretamente diversos ecossistemas devido a sua infiltração no solo e, consequentemente, mananciais superficiais e subterrâneos;

- Animais que são criados soltos em zonas periféricas podem se alimentar de restos de resíduos orgânicos em decomposição e podem se tornar vetores transmissores de doenças, quando sua carne ou leite são ingeridos pelo ser humano; 
- As crianças são mais vulneráveis aos riscos associados aos resíduos sólidos urbanos gerenciados inadequadamente pois brincam em áreas de beira de córregos e terrenos baldios, onde podem existir resíduos contaminados com parasitas, vírus e bactérias e também porque possuem taxa de respiração mais rápida, o que as torna mais suscetíveis, quando comparadas aos adultos, a riscos respiratórios, no caso de inalação de gases tóxicos, absorção química e queimaduras;

- O metabolismo de desintoxicação e excreção de toxinas das crianças não está totalmente desenvolvido e, portanto, em caso de ingestão de substâncias tóxicas que podem estar presentes nos RSU, os efeitos são maiores, se comparados em adultos;

- A importação dos resíduos sólidos pelos países pobres aumenta os riscos de geração de enfermidades nas populações receptoras pois existem mais indivíduos sobrevivendo da coleta e separação dos RSU.

Uma das soluções para reduzir os danos e impactos negativos causados pela gestão inadequada dos RSU é a implantação e operação de processos de reutilização e reciclagem, lastreadas por políticas públicas que priorizam o não aterramento dos resíduos sólidos.

Neste sentido, este estudo teve como foco, identificar municípios que possuem coleta seletiva, suas características operacionais e quais foram as políticas públicas que contribuíram para aumentar as taxas de coleta seletiva de RSU. A partir de critérios de seleção, foram selecionados para um estudo comparativo, três cidades: São Francisco, Estados Unidos da América; Cidade do Cabo, África do Sul; e São Paulo, Brasil.

Segundo o Banco Mundial, a gestão e o gerenciamento inadequado causam, também, efeitos negativos para a economia, uma vez que, o custo da gestão correta dos resíduos é menor, quando comparado aos custos de despoluição e descontaminação (WORLD BANK, 2012). 
Portanto, políticas públicas de resíduos sólidos urbanos que preconizam a minimização da geração, operacionalização de coleta seletiva para reutilização e reciclagem, tratamento dos resíduos, implantação de unidades de disposição final adequadas ambientalmente, podem contribuir positivamente com a melhoria da saúde, da qualidade de vida das populações, com o meio ambiente, com a preservação dos recursos naturais e diminuição de gases do efeito estufa.

Ao tratar o tema do gerenciamento dos RSU e suas conexões com ações globais de desenvolvimento, condensadas nos dezessete Objetivos de Desenvolvimento Sustentável (ODS) propostos pelas Nações Unidas para 2030 e aprovados em setembro de 2015 , destacam-se seis que têm relação com o gerenciamento dos resíduos sólidos, a saber:

- Objetivo 3: assegurar uma vida saudável e promover o bem-estar para todas e todos, em todas as idades. Reduzir substancialmente o número de mortes e doenças por produtos químicos perigosos, contaminação e poluição do ar, da água e do solo;

- Objetivo 8: promover o crescimento econômico sustentado, inclusivo e sustentável, emprego pleno e produtivo e trabalho decente para todas e todos. Melhorar progressivamente, até 2030, a eficiência dos recursos globais no consumo e na produção e empenhar-se para dissociar o crescimento econômico da degradação ambiental, de acordo com o Plano Decenal de Programas sobre Produção e Consumo Sustentáveis, com os países desenvolvidos assumindo a liderança;

- Objetivo 11: tornar as cidades e os assentamentos humanos inclusivos, seguros, resilientes e sustentáveis. Até 2030, reduzir o impacto ambiental negativo per capita das cidades, inclusive prestando especial atenção à qualidade do ar, gestão de resíduos municipais e outros. Até 2020, aumentar substancialmente o número de cidades e assentamentos humanos adotando e implementando políticas e planos integrados para a 
inclusão, a eficiência dos recursos, mitigação e adaptação às mudanças climáticas e a resiliência a desastres;

- Objetivo 12: assegurar padrões de produção e de consumo sustentáveis. Até 2030, alcançar a gestão sustentável e o uso eficiente dos recursos naturais. Até 2020, alcançar o manejo ambientalmente saudável dos produtos químicos e de todos os resíduos, ao longo de todo o ciclo de vida destes, de acordo com os marcos internacionais acordados, e reduzir significativamente a liberação destes para o ar, água e solo, para minimizar seus impactos negativos sobre a saúde humana e o meio ambiente. Até 2030, reduzir substancialmente a geração de resíduos por meio da prevenção, redução, reciclagem e reuso. Promover práticas de compras públicas sustentáveis, de acordo com as políticas e prioridades nacionais. Até 2030, garantir que as pessoas, em todos os lugares, tenham informação relevante e conscientização para o desenvolvimento sustentável e estilos de vida em harmonia com a natureza. Apoiar países em desenvolvimento a fortalecer suas capacidades científicas e tecnológicas para mudar para padrões mais sustentáveis de produção e consumo;

- Objetivo 13: tomar medidas urgentes para combater as mudanças climáticas e seus impactos. Integrar medidas da mudança do clima nas políticas, estratégias e planejamentos nacionais. Promover mecanismos para a criação de capacidades para o planejamento relacionado à mudança do clima e à gestão eficaz, nos países menos desenvolvidos, inclusive com foco em mulheres, jovens, comunidades locais e marginalizadas;

- Objetivo 17: fortalecer os meios de implementação e revitalizar a parceria global para o desenvolvimento sustentável. Aumentar a coerência das políticas para o desenvolvimento sustentável. Incentivar e promover parcerias públicas, público-privadas e com a sociedade civil eficazes, a 
partir da experiência das estratégias de mobilização de recursos dessas parcerias.

Assim, investigar como três municípios em diferentes países vem conduzindo a separação de resíduos para reaproveitamento e reciclagem constitui uma pesquisa de saúde global (FORTES e RIBEIRO, 2014) nos seguintes aspectos: (i) a gestão da coleta seletiva/reciclagem envolve conceitos de integralidade e interdisciplinaridade; (ii) necessita de acordos regulatórios que transcendem limites municipais, regionais e nacionais; (iii) a minimização de aterramento de resíduos contribui com a saúde do ambiente e das pessoas de todo planeta; (iv) constitui um problema enfrentado por todas as cidades do mundo, em diferentes intensidades, que podem usufruir de achados importantes desta pesquisa. 


\section{IMPACTOS À SAÚDE E AO MEIO AMBIENTE DO GERENCIAMENTO INADEQUADO DE RESÍDUOS SÓLIDOS URBANOS E AÇÕES DE MINIMIZAÇÃO}

A matéria orgânica presente nos RSU é fonte de atração de vetores transmissores de doenças. Além disso, os animais peçonhentos (serpentes e artrópodes) encontram nos resíduos dispostos irregularmente, um ambiente propício para sobreviver.

No Brasil, segundo a FUNASA (2015), os vetores transmissores de doenças (ratos, pulga, moscas, mosquitos, baratas, gado, porcos, cães e gatos) têm no ambiente dos resíduos sólidos, sejam orgânicos ou inorgânicos, locais propícios para se reproduzirem e se multiplicarem. Algumas das doenças relacionadas aos vetores mencionados são: cisticercose, cólera, disenteria, febre tifoide, filariose, giardíase, leishmaniose, leptospirose, peste bubônica, salmonelose, toxoplasmose, tracoma, triquinose e outras (FUNASA, 2015).

Além disso, pode-se ainda mencionar os ambientes cujos resíduos inertes (restos de entulho, madeiras, plásticos, ferragens, etc.) e resíduos orgânicos, acumulados em locais ao ar livre e sem organização, tornam-se propícios para o abrigo, a reprodução e proporcionam fonte de alimentos (roedores, insetos em geral) para alguns animais peçonhentos (INSTITUTO BUTANTÃ, 2014).

Segundo o Instituto Butantã serpentes e artrópodes peçonhentos (aranhas e escorpiões) têm "uma tendência crescente a se adaptarem ao ambiente urbano, devido à facilidade de encontrarem alimento, como baratas e roedores". Bochner (2003) também ressalta a grande incidência de acidentes com animais peçonhentos e seus impactos negativos para a saúde pública:

Hoje em dia os acidentes por animais peçonhentos continuam a constituir um sério problema de saúde pública no Brasil, tanto pelo número de casos registrados, em média 20.000 casos de acidentes com serpentes, 5.000 com aranhas e 8.000 por escorpiões por ano, quanto pela gravidade apresentada, podendo conduzir à morte ou a sequelas capazes de gerar incapacidade temporária ou definitiva 
para o trabalho e para as atividades habituais de lazer (BOCHNER, 2003: 12)

Os resíduos sólidos não recolhidos das habitações, das vias de circulação e espaços públicos também dão origem às reclamações das comunidades, pois o odor desagradável, a sensação de sujeira, de desorganização e de abandono, em geral, não é aceita pelos munícipes.

Moraes (2007) publicou uma pesquisa realizada entre 1989 e 1990, em assentamentos periurbanos de Salvador, BA, cujo objetivo foi verificar os impactos na saúde das crianças até 15 anos da forma de acondicionamento dos resíduos sólidos nas residências e nos assentamentos. O termo "impacto" utilizado pelo autor era associado ao risco de crianças contraírem mais doenças nas residências em que os resíduos sólidos eram acondicionados inadequadamente (em caixas de papelão, caixotes, sem tampas) e nos assentamentos em que não havia coleta regular de resíduos. Os resultados da pesquisa apontaram para uma:

...associação estatisticamente significante entre 0 tipo de acondicionamento domiciliar dos resíduos sólidos bem como entre a coleta de resíduos sólidos domiciliares no ambiente de domínio público e a prevalência de $\mathrm{A}$. limbricoides, $\mathrm{T}$. trichiura $\mathrm{e}$ ancilostomídeos em crianças entre 5 e 14 anos de idade, mesmo quando outros fatores socioeconômicos, culturais, demográficos e ambientais são considerados e a incidência de diarréia e o estado nutricional das crianças menores de cinco anos residentes em assentamentos periurbanos (MORAES, 2007: 647)

A disposição de RSU diretamente no solo (lixões) causa impactos como: (i) contaminação dos mananciais superficiais e subterrâneos devido à percolação do chorume gerado na decomposição da matéria orgânica, que altera as características físicas, químicas e biológicas da água, tornando-a imprópria para o consumo; (ii) contaminação do solo devido à presença de metais pesados e outras substâncias tóxicas contidas em embalagens de produtos químicos, farmacêuticos, de higiene e limpeza, agroquímicos, tintas, 
solventes que alteram as características físico-químicas do solo; (iii) risco de incêndios e explosões espontâneas, especialmente em lixões e aterros controlados, devido à geração de gás metano, decorrente da decomposição da matéria orgânica que, em contato com o oxigênio da atmosfera, entra em combustão; (iv) poluição atmosférica causada pelo surgimento de gases, especialmente o gás metano gerado no processo de decomposição da matéria orgânica presente; (v) atração da avifauna que busca nos resíduos orgânicos seu alimento e, inclusive, dependendo do local do lixão ou aterro controlado, aumentam os riscos de acidentes com aeronaves; (vi) ambientes insalubres (risco de contaminação por produtos químicos e agentes patogênicos) para catadores que estão presentes nas frentes de descarga de resíduos em locais não controlados e, também, aumentam os riscos de acidentes, tais como: atropelamento devido à movimentação de equipamentos pesados (caminhões e tratores), perfuração e cortes que podem ser causados pela presença de material perfurocortante; (vii) riscos de desestabilização da massa de resíduos devido à ausência de sistemas de drenagens de águas pluviais e chorume, ausência de compactação e recobrimento com solo da massa de resíduos, podendo ocasionar deslizamentos e soterramentos, dependendo das condições topográficas.

Possamai et al. publicaram, em 2007, um levantamento realizado nos lixões inativos na região carbonífera de Santa Catarina, composta por 11 municípios, sobre os riscos à saúde da população e ao ambiente. A pesquisa foi realizada com base em entrevistas feitas por questionários previamente definidos junto aos representantes municipais responsáveis pelos lixões visitados. Os pesquisadores definiram "indicadores de grau de risco" dos lixões classificando-os em: baixo, regular e crítico (POSSAMAl et al., 2007: 174). Os indicadores se basearam em oito parâmetros: proximidade de corpos de água superficiais, coleta e tratamento de biogás, coleta e tratamento de águas pluviais, coleta e tratamento de chorume, monitoramento nos lixões inativos, 
proximidade de residências, existência de cercas e tipo de cobertura e utilização de manta. Os pesquisadores constataram que:

Observa-se, de modo geral, que todos os resultados apontaram para uma situação global crítica em todos os municípios que possuem lixões inativos. Apesar de alguns dos lixões possuírem classificação de risco regular ou baixo para um ou outro parâmetro, eles ainda expõem, na análise conjunta dos parâmetros, o meio ambiente e a saúde conjunta dos parâmetros, o meio ambiente e a saúde pública. Esta avaliação é fortalecida ainda pelo fato de que nenhum dos municípios apresentava, no período dessa avaliação, mecanismos ou normas legais para a inativação dos seus lixões (POSSAMAI et al., 2007: 177)

Os aterros controlados, que não dispõem de sistemas de controle da poluição ambiental (impermeabilização de fundo, drenos para captação de gases, sistemas de drenagens de águas pluviais, tratamento de chorume), também são fontes de poluição ambiental para as bacias hidrográficas, solo e atmosfera, mesmo depois do encerramento de suas atividades operacionais.

Gouveia e Prado (2010) analisaram, entre 1998 e 2002, o risco para a saúde na ocorrência de câncer e malformações congênitas nas áreas próximas a 15 aterros de resíduos sólidos urbanos no município de São Paulo (GOUVEIA; PRADO, 2010). A pesquisa verificou os números de óbitos por câncer de fígado, de bexiga e leucemia em adultos e crianças, bem como malformação congênita, nas áreas dos entornos dos aterros num raio de 2 quilômetros. Os resultados apontaram que as mortes se localizavam nas regiões centrais da cidade de São Paulo e não indicaram excesso de risco para os moradores de áreas próximas aos aterros. Entretanto, para os aterros ainda em funcionamento na época da pesquisa, os pesquisadores verificaram um "risco aumentado para câncer de bexiga, fígado e para mortes por malformações congênitas, porém sem significância estatística" (GOUVEIA; PRADO, 2010: 859).

Os sistemas de tratamento e disposição final de resíduos sólidos (centrais de compostagem, de triagem, incineradores), fora dos padrões técnicos de 
controle, contribuem para a desvalorização imobiliária das regiões onde estão instalados, assim como, ao longo de seus acessos, devido à circulação de caminhões e carretas carregadas com resíduos sólidos.

As emissões atmosféricas de gases provenientes da decomposição da parcela de resíduos orgânicos presentes nos RSU, sistemas de tratamento e/ou sistemas de tratamento ineficientes, contribuem com a poluição atmosférica urbana e potencializam o Efeito Estufa (EE).

A organização das Nações Unidas vem discutindo os efeitos deletérios das alterações climáticas globais, notadamente o aquecimento global e suas consequências para a saúde, o ambiente, as economias mundiais e a sustentabilidade do planeta desde 1979, quando da primeira Conferência Mundial do Clima (UN, 2014).

As Nações Unidas e suas agências mencionam que os padrões climáticos alterados em função das ações antrópicas vêm provocando alterações dos níveis dos mares e efeitos climáticos mais extremos em função dos Gases do Efeito Estufa (GEE) emitidos pelas atividades humanas e que a temperatura da superfície terrestre poderá aumentar em até $3^{0} \mathrm{C}$, ao longo do século XXI (UN, 2014).

Algumas das soluções visualizadas para prevenção do aquecimento global, pelos especialistas envolvidos no tema, são a redução dos GEE, notadamente emissões de poluentes climáticos de curta duração ou short lived climate pollutants (SLCP), presentes na cadeia dos RSU (UN, 2014).

Diversas conferências, reuniões e painéis internacionais sobre o tema ocorreram nas últimas décadas, apresentadas cronologicamente: 1988 - Painel Intragovernamental de Mudanças Climáticas (IPCC); 1992 - Rio 92, assinatura do Painel das Nações Unidades para a Convenção das Mudanças Climáticas; 1997 - Protocolo de Quioto; 2007 - lançamento do 4ํ Relatório do IPCC com o tema das Mudanças Climáticas cujo problema exposto foi fortemente absorvido pela sociedade mundial; 2014 - na Assembleia Geral das Nações Unidas, 
líderes globais de governos, empresas e da sociedade civil anunciaram compromissos para reduzir as emissões dos GEE em oito áreas críticas e barrar o aquecimento global: agricultura, cidades, energia, finanças, florestas, industrias, resiliência e transporte; 2015 - COP 21, acordo assinado em Paris por diversos países com o compromisso da redução das emissões dos GEE (UN, 2014).

Em 2014, os líderes identificaram a necessidade de ações executivas para os sistemas de RSU, principalmente para as disposições finais pois os aterros são o terceiro maior emissor de gás Metano $(\mathrm{CH} 4)$ antropogênico no mundo, representando $11 \%$ de toda a emissão global (UN, 2014). Além disto, o setor de resíduos também contribui com as emissões de gás Carbono $(\mathrm{C})$ e gás Dióxido de Carbono $\left(\mathrm{CO}_{2}\right)$ decorrentes de queimas a céu aberto de resíduos lançados ao ar livre, e das emissões de gases durante o transporte de resíduos com equipamentos obsoletos (UN, 2014).

Diante da constatação da contribuição dos resíduos sólidos para o Aquecimento Global, a organização das Nações Unidas formou a Coalisão para - Clima e Ar Limpo (Climate and Clean Air Coalition - CCAC) que traçou um Plano de Ação, cujo foco foi reduzir as emissões dos poluentes climáticos de curta duração, presentes nas cadeias de resíduos sólidos por meio de sistemas de gerenciamento adequados de resíduos sólidos.

O Plano de Ação inicial contemplou 25 cidades ao redor do mundo, que se comprometeram a reduzir as emissões de GEE associados aos sistemas de resíduos sólidos: Abidjan, Accra, Addis Ababa, Amman, Barranquilla, Battambang, Cali, Cebu City, Concepcion, Dhaka, Jakarta, Johannesburg, Kitakyushu, Lagos, Lima, Penang, Phitsanulok, Queretaro, Rio de Janeiro, San Diego, San Francisco, Stockholm, Umeå, Viña del Mar e Yamoussoukro. As metas posteriores do Plano são, até dezembro de 2020, envolver 150 cidades ao redor do mundo (UN, 2014) na redução das emissões de GEE causadas por RSU. 
O Plano de Ação pretende treinar as cidades piloto para projetar e implantar sistemas integrados de resíduos sólidos que sejam sustentáveis financeiramente e, ainda, envolver os setores públicos e privados para financiar a execução dos sistemas de resíduos. Em termos práticos, as cidades deverão implantar um conjunto de práticas sustentáveis que incluam foco nas seguintes perspectivas: minimizar a geração de resíduos, com foco na diminuição da geração de resíduos orgânicos; aumentar a cobertura de coleta; melhorar os sistemas de transporte de resíduos; aumentar os recursos na separação dos resíduos; reutilizar e reciclar resíduos, foco desta pesquisa; implantar compostagem ou digestão para resíduos biodegradáveis; implantar aterros sanitários com captação de gases para utilização (UN, 2014).

Lakhan (2016) menciona que, nos países desenvolvidos, ações de reutilização, reaproveitamento e reciclagem de RSU foram encampadas para o combate à poluição ambiental e suas consequências danosas à saúde pública e ao ambiente, especialmente em situações de acidentes ambientais, nas décadas de 1970 e 1980. Nas últimas décadas, especialmente, a partir da assinatura do Protocolo de Quioto em 1997, os esforços dos países têm sido focados em ampliar as políticas públicas que estimulam a reutilização, o reaproveitamento e a reciclagem dos RSU pois a geração de Metano $(\mathrm{CH} 4)$ e o Dióxido de Carbono $\left(\mathrm{CO}_{2}\right)$ que representam $97 \%$ dos GEE, estão fortemente associados à gestão e gerenciamento inadequados de sistemas de RSU. O autor menciona ainda que o Metano, gerado na decomposição da matéria orgânica presente nos RSU, pode ser minimizado a partir de processos tecnológicos adequados que inibem as emissões para a atmosfera. No caso do Dióxido de Carbono, o estímulo à reutilização e reciclagem reduz o uso de matérias primas virgens e, consequentemente, contribui para a redução de emissões.

Portanto, seja em abordagens mais globais ou em estudos aplicados aos sistemas de resíduos sólidos urbanos, é notória a necessidade de diminuir e/ou 
eliminar técnicas de aterramento de resíduos, para substituí-las por outras tecnologias que permitam a reutilização e a reciclagem, de modo a contribuir com a diminuição das emissões dos GEE.

A circulação da frota de equipamentos da limpeza urbana, predominantemente de caminhões movidos a diesel, utilizados para as coletas de RSU e coleta seletiva, contribui negativamente para a poluição atmosférica, especialmente em modelos operacionais de coleta porta a porta, com reduzida otimização de roteiros de coleta.

Os sistemas de limpeza urbana usam equipamentos movidos a combustíveis fósseis como caminhões de diversos tamanhos e outros equipamentos. Com o aumento das quantidades de resíduos sólidos urbanos gerados, são necessários mais equipamentos e maior frequência de viagens para manter as condições adequadas de limpeza pública nas cidades.

As emissões de gases poluentes gerados na combustão dos caminhões da coleta (monóxido de carbono - CO, hidrocarbonetos não metano - NMHC, óxidos de nitrogênio - $\mathrm{NOx}$, dióxido de enxofre - $\mathrm{SO}$, aldeídos totais - $\mathrm{RCHO}$ e material particulado - MP), constituem um elemento negativo a mais nos sistemas de limpeza pública mal geridos. Segundo Teixeira et al. (2008), os veículos pesados (ônibus e caminhões) são responsáveis pela maior fração das emissões de óxidos de nitrogênio e de enxofre e seu combustível, o diesel, "é notadamente o combustível mais poluente e economicamente custoso, se considerarmos todas as perdas ambientais, infraestruturas e governamentais do seu uso" (TEIXEIRA et al., 2008: 244). Também se observa efeitos nocivos à saúde devido os gases inalados (DRUMM et al., 2014).

A ineficiência do sistema de limpeza urbana, especialmente nas áreas periféricas das cidades de países em desenvolvimento, onde a coleta de resíduos e a limpeza e desobstrução de sistemas de drenagens urbanas são insuficientes, contribui significantemente para aumentar os riscos de 
alagamentos pois resíduos são carreados pelas águas pluviais para o sistema de drenagens e várzeas.

Nas situações de desastres e de conflitos armados, um dos grandes problemas para o poder público é a remoção de grandes quantidades de resíduos sólidos (urbanos, solo, entulhos, vegetação, etc.) em áreas habitadas. Nestas situações, depois das perdas humanas, são as paralizações totais dos sistemas de saneamento básico (fornecimento de água, coleta de esgoto, energia elétrica) e ausência de coleta de resíduos, que aumentam o caos sanitário, ao propiciar contato primário com matéria orgânica em decomposição com águas contaminadas, excrementos, em locais de acúmulo de pessoas enfermas em abrigos e campos de refugiados.

A ineficiência do sistema de limpeza urbana ainda fere o princípio constitucional da eficiência, no caso brasileiro:

Art. 37 - A Administração pública direta e indireta de qualquer dos poderes da União, dos Estados, do Distrito Federal e dos Municípios obedecerá aos princípios de legalidade, impessoalidade, moralidade, publicidade e eficiência (...)" (BRASIL, 1998)

Di Pietro aponta que o serviço público, inclusive a limpeza pública "é toda atividade que a administração pública executa, direta ou indiretamente, para satisfazer à necessidade coletiva, sob regime jurídico predominantemente público" (DI PIETRO, 2001: 60). O autor ainda menciona que os interesses públicos têm supremacia sobre os individuais e o poder público deve zelar pela satisfação dos interesses coletivos, sendo a eficiência um dos deveres da Administração Pública. Neste sentido, expandir as ações de limpeza pública, incluindo os serviços de coleta seletiva, a reutilização e a reciclagem, é uma obrigação das Administrações Públicas.

A presente pesquisa foi motivada pelos problemas anteriormente mencionados e pelo compromisso da autora em contribuir para a melhoria e a eficiência das políticas de limpeza urbana. 


\section{OBJETIVOS}

O objetivo desta tese foi identificar e avaliar a coleta de resíduos sólidos urbanos e políticas públicas municipais que contribuem para minimizar os impactos negativos à saúde pública e ao meio ambiente, por meio de estudo de casos comparativos de três cidades: São Paulo (Brasil), Cidade do Cabo (África do Sul) e São Francisco (Estados Unidos).

Os objetivos específicos são:

- Caracterizar as coletas de resíduos sólidos urbanos que possuem segregação de resíduos na fonte nos três municípios por meio das variáveis: ocorrência, abrangência, regularidade, eficiência, desvio/separação de resíduos por tipo, incorporação quanto aos executores;

- Identificar as políticas públicas e instrumentos legais e de planejamento em vigor nos três municípios para o gerenciamento integrado dos resíduos sólidos urbanos;

- Realizar a avaliação comparativa do gerenciamento das políticas públicas que favorecem a coleta com segregação na fonte geradora (coleta seletiva), a partir de referencial desenvolvido pela autora. 


\section{REFERENCIAIS TEÓRICOS}

\subsection{BENEFÍCIOS DA REUTILIZAÇÃO E RECICLAGEM DE RESÍDUOS SÓLIDOS URBANOS}

Conforme exposto anteriormente, os Resíduos Sólidos Urbanos (RSU) que não recebem tratamento e disposição adequada causam diversos impactos negativos para a saúde pública, contribuem com a poluição ambiental e impactam outros elementos das áreas urbanas.

Uma das alternativas para minimizar estes impactos negativos são os processos de reutilização e reciclagem, precedidos da separação dos resíduos na fonte geradora e na coleta específica (seletiva) pois conforme apontado por Besen et.al. "contribuem para a sustentabilidade urbana com reflexos na saúde ambiental e humana" (BESEN et.al, 2014). A separação dos resíduos na fonte geradora para fins de reciclagem visando reprocessá-los ou utilizá-los como recurso material nos processos produtivos é uma alternativa viável e uma tendência internacional.

Os principais benefícios dos processos de separação dos resíduos na fonte são:

- Redução da exploração de recursos naturais e, consequentemente, a conservação dos mesmos;

- Diminuição do consumo de energia elétrica e do uso de combustíveis fósseis;

- Redução das emissões de gases do efeito estufa, em especial o metano e dióxido de carbono;

- Incentivo à economia circular;

- Estímulo à sustentabilidade;

- Aumento da vida útil dos aterros sanitários;

- Aumento da geração de empregos, quando comparado aos métodos de aterramento de RSU; 
- Promoção de ambientes mais saudáveis para trabalhadores dos setores de RSU.

Em diversos processos produtivos para a fabricação de bens duráveis e não duráveis, a extração de recursos naturais e sua transformação provocam grandes alterações no ambiente natural e/ou urbano. Materiais descartados podem ser reintroduzidos nos processos produtivos, minimizando a extração de recursos e poupando recursos naturais (solo, vegetação, água). O reaproveitamento dos resíduos permite redução das emissões de GEE, conforme apontado pelo ICF (ICF Consulting, 2005).

A Tabela 1 apresenta o consumo de energia nos processos produtivos com matéria prima e a partir de resíduos de residências no Canadá. Os dados apontam grandes economias energéticas quando se recuperam os resíduos.

Tabela 1 Gasto de energia elétrica na produção de bens de consumo com matéria prima e com uso de resíduos sólidos, Canadá, 2005

Materiais

\begin{tabular}{l|c|c}
\hline \multirow{2}{*}{ Materiais } & \multicolumn{2}{|c}{$\begin{array}{c}\text { Gasto com energia elétrica na produção de } \\
\text { bens de consumo (Gj/T) }\end{array}$} \\
\cline { 2 - 3 } & $\begin{array}{c}\text { Produção com uso } \\
\text { matéria prima virgem }\end{array}$ & $\begin{array}{c}\text { Produção com uso de } \\
\text { resíduos sólidos }\end{array}$ \\
\hline Alumínio & 64,19 & 6,18 \\
\hline Aço & 22,67 & 9,30 \\
\hline Fio de cobre & 67,87 & 6,00 \\
\hline Vidro & 6,00 & 4,20 \\
\hline Plástico polietileno de alta & 33,25 & 6,00 \\
\hline densidade (HDPE) & 62,21 & 6,00 \\
\hline Plástico PET & 35,25 & 6,00 \\
\hline Outros plásticos & 102,53 & 42,11 \\
\hline Pneu & 14,11 & 8,35 \\
\hline Papel jornal & 30,93 & 12,78 \\
\hline Papelão & 35,23 & 13,09 \\
\hline Papel fino & 32,56 & 10,30 \\
\hline Outros papéis & &
\end{tabular}

Fonte: ICF Global Consulting Services, 2005

A União Europeia considera que o reaproveitamento e a reciclagem de resíduos sólidos urbanos é "essencial para extrair mais valor dos recursos, reduzindo as pressões sobre o meio ambiente e criando empregos" 
(EUROPEAN ENVIRONMENTAL AGENCY, 2013, p. 77). Existe ganho socioambiental pois haverá menor degradação ambiental. Associado a este fator, conforme Lakhan (2016), a manutenção de áreas com cobertura vegetal aumenta o sequestro de dióxido de carbono, minimizando os efeitos antrópicos de emissões de GEE.

Alguns aspectos desfavoráveis aos processos de reciclagem (HUTCHINSON, 2008) seriam as frotas de caminhões para o transporte de materiais recicláveis, da coleta até as unidades de processamento e os usos de energia nos processos de reciclagem, gerando poluição.

Entretanto Morris (1996) investigou o ciclo de vida de quatro produtos, contabilizando a quantidade de energia gasta para a coleta e o transporte até a reintrodução em algum processo produtivo versus a coleta e o transporte dos resíduos para aterros sanitários, incineradores ou outras unidades de tratamento. Segundo Morris, 1 tonelada de material virgem consome 23,3 milhões de Btu (British Thermal Unit) e 1 tonelada de materiais recicláveis consome 10,4 milhões de Btu. Chegou à conclusão que o uso de resíduos reciclados consome menos energia que processos que utilizam matérias primas (Quadro 1).

Quadro 1 Porcentagem de energia gasta no processo produtivo com materiais recicláveis em relação a matéria prima

\begin{tabular}{l|c}
\hline Material & $\begin{array}{l}\text { \% de energia gasta no processo produtivo com uso } \\
\text { de materiais recicláveis em relação a matéria prima }\end{array}$ \\
\hline Latas de alumínio & $96 \%$ \\
\hline Vidro & $21 \%$ \\
\hline Garrafas plásticas & $76 \%$ \\
\hline Papel jornal & $45 \%$ \\
\hline Fon
\end{tabular}

Fonte: Environmental Consultant Jeffrey Morris, 1996

Os estudos de Morris (1996) também apontaram que os melhores sistemas de reciclagem são aqueles onde há um circuito fechado, isto é, os 
resíduos têm origem definida e são encaminhados diretamente à processos produtivos.

Mabee (2011) apresenta, em seu estudo de economia circular realizado no Canadá para o setor florestal (indústria da celulose), que o fluxo ótimo de bens e serviços pode ser representado como um loop: quando um processo recupera os produtos após um período de uso e os transforma em novos produtos, ou seja, o último produto pode ser usado como base para uma nova produção, trazendo o produto ao ponto de partida do processo produtivo e ainda, proporciona o sequestro de carbono nas florestas, à medida que diminui a necessidade de corte de novas árvores para a indústria florestal.

A Agência de Proteção Ambiental Americana (USEPA, 2014) calculou o efeito da reciclagem e da compostagem dos resíduos na geração de GEE utilizando o Modelo de Redução de Resíduos (sigla WARM). A Tabela 2 mostra que, em um ano, foram retirados da atmosfera cerca de 150 milhões de toneladas métricas de dióxido de carbono, equivalente a retirada de 31 milhões de carros das ruas.

Tabela 2 Quantidade de material recuperada, GEE emitidos a partir do uso de materiais recuperados e equivalência do número de automóveis retirados de estradas estimados pela USEPA nos Estados Unidos, 2013

\begin{tabular}{|l|r|r|r}
\hline Material & $\begin{array}{c}\text { Quantidade } \\
\text { Material } \\
\text { Recuperada } \\
\text { (toneladas) }\end{array}$ & $\begin{array}{c}\text { GEE } \\
\text { emitidos } \\
\text { MMTCO }_{2} \mathbf{E}^{(1)}\end{array}$ & $\begin{array}{c}\text { Equivalência do } \\
\text { Número de } \\
\text { Automóveis } \\
\text { Retirados das } \\
\text { Estradas por Ano }\end{array}$ \\
\hline Papel e papelão & 43.000 .000 & 149,00 & 31.000 .000 \\
\hline Vidro & 3.200 .000 & 1,00 & 210.000 \\
\hline Metais: & 5.800 .000 & 9,50 & 2.000 .000 \\
\hline Aço & 700.000 & 6,40 & 1.300 .000 \\
\hline Alumínio & 1.370 .000 & 5,90 & 1.200 .000 \\
\hline Outros Metais Não & 7.870 .000 & 21,80 & 4.500 .000 \\
\hline Ferrosos ${ }^{(2)}$ & 3.000 .000 & 3,60 & 760.000 \\
\hline Total metais & & & \\
\hline Plásticos & &
\end{tabular}




\begin{tabular}{|c|c|c|c|}
\hline Material & $\begin{array}{l}\text { Quantidade } \\
\text { Material } \\
\text { Recuperada } \\
\text { (toneladas) }\end{array}$ & $\begin{array}{c}\text { GEE } \\
\text { emitidos } \\
\text { MMTCO }_{2} \text { (1) }^{(1)}\end{array}$ & $\begin{array}{l}\text { Equivalência do } \\
\text { Número de } \\
\text { Automóveis } \\
\text { Retirados das } \\
\text { Estradas por Ano }\end{array}$ \\
\hline Borracha e Couro ${ }^{(3)}$ & 1.240 .000 & 0,60 & 127.000 \\
\hline Tecidos & 2.300 .000 & 5,80 & 1.200 .000 \\
\hline Madeira & 2.470 .000 & 3,80 & 798.000 \\
\hline $\begin{array}{l}\text { Outros resíduos: } \\
\text { Alimentos, outros }{ }^{(4)}\end{array}$ & 1.840 .000 & 1,70 & 308.000 \\
\hline Aparas jardim & 20.600 .000 & 1,04 & 220.000 \\
\hline
\end{tabular}

Fonte: USEPA, Relatório Gestão Sustentável Avançada de Materiais da Agência de Proteção Ambiental dos Estados Unido.

Nota: (1) $\mathrm{MMTCO}_{2} \mathrm{E}$ : milhões de toneladas métricas de dióxido de carbono equivalente. (2) Inclui chumbo de baterias de chumbo-ácido. Outros metais não ferrosos calculados em WARM como metais misturados. (3) A recuperação só inclui borracha de pneus. (4) Inclui recuperação de outros compostos orgânicos para compostagem de resíduos sólidos urbanos.

\subsection{ESTUDO REFERENCIAL DE GERENCIAMENTO DE RESÍDUOS SÓLIDOS URBANOS}

Wilson et al. (2012) realizaram importante estudo comparativo sobre o gerenciamento de resíduos sólidos de 20 cidades no mundo, que envolveu 35 especialistas em resíduos sólidos, que haviam trabalhado no Terceiro Relatório Global sobre Água e Saneamento em Cidades do Mundo/Gerenciamento de Resíduos Sólidos para a conferência "Fifth World Urban Forum" das Nações Unidas - HABITAT, no Rio de Janeiro em 2010.

$O$ estudo foi baseado no conceito de gerenciamento integrado $e$ sustentável de resíduos sólidos que apresenta duas grandes linhas focais, ambas compostas por três componentes (Quadro 2).

Quadro 2 Linhas de análise do estudo comparativo

\begin{tabular}{|l|l|}
\hline \multicolumn{1}{|c|}{ Linha Focal } & \multicolumn{1}{c|}{ Componentes } \\
\hline $\begin{array}{l}\text { Componentes } \\
\text { Físicos para }\end{array}$ & $\begin{array}{l}\text { Saúde pública: manutenção das condições de saúde nas } \\
\text { cidades por meio de bom serviço de coleta de resíduos }\end{array}$ \\
\hline
\end{tabular}




\begin{tabular}{|l|l|}
\hline \multicolumn{1}{|c|}{ Linha Focal } & \multicolumn{1}{|c|}{ Componentes } \\
\hline $\begin{array}{l}\text { desenvolvimento } \\
\text { dos sistemas de } \\
\text { resíduos sólidos }\end{array}$ & $\begin{array}{l}\text { Meio ambiente: proteção ambiental por meio da cadeia de } \\
\text { resíduos sólidos, especialmente nas fases de tratamento e } \\
\text { disposição final }\end{array}$ \\
\hline $\begin{array}{l}\text { Gerenciamento de recursos: ciclo de reciclagem, onde os } \\
\text { recursos (orgânicos e inorgânicos) são reintroduzidos em } \\
\text { processos ou minimizados, por meio da prevenção da } \\
\text { geração, reutilização, sistemas de reciclagem em } \\
\text { recuperação }\end{array}$ \\
\hline $\begin{array}{l}\text { Componentes } \\
\text { de Estratégias } \\
\text { Governamentais } \\
\text { para sistema } \\
\text { eficiente de } \\
\text { resíduos sólidos }\end{array}$ & $\begin{array}{l}\text { Inclusão: promover abertura para atores sociais } \\
\text { contribuírem no sistema como usuários, provedores e } \\
\text { facilitadores }\end{array}$ \\
\cline { 2 - 2 } & $\begin{array}{l}\text { Sustentabilidade financeira: rentável e acessível } \\
\text { Políticas públicas: base de instituições sólidas e políticas } \\
\text { proativas }\end{array}$ \\
\hline
\end{tabular}

Fonte: Wilson et al. (2012)

Para a comparação dos dados coletados nas 20 cidades, Wilson et al. (2012) utilizaram benchmarks (Quadro 3) como referência para a preparação do roteiro de entrevista aplicadas no levantamento de campo nos três municípios do estudo.

Quadro 3 Benchmark no estudo comparativo

\begin{tabular}{|l|l|l|l|}
\hline N. & $\begin{array}{l}\text { Critério } \\
\text { Analítico }\end{array}$ & Indicador & Descrição \\
\hline Componentes Físicos & Saúde Pública & $\begin{array}{l}\text { Cobertura da } \\
\text { coleta e e } \\
\text { varrição }\end{array}$ & $\begin{array}{l}\text { Quantidade percentual de cidadãos que } \\
\text { tem acesso confiável ao serviço de } \\
\text { coleta de resíduos }\end{array}$ \\
\hline 2 & $\begin{array}{l}\text { Controle } \\
\text { Ambiental }\end{array}$ & $\begin{array}{l}\text { Controle da } \\
\text { disposição }\end{array}$ & $\begin{array}{l}\text { Quantidade percentual do total de } \\
\text { resíduos destinados enviado para } \\
\text { aterro sanitário, disposição controlada } \\
\text { ou qualquer tipo de tratamento } \\
\text { controlado, inclusive tratamento térmico }\end{array}$ \\
\hline 3 & $\begin{array}{l}\text { Gerenciamento } \\
\text { dos Recursos }\end{array}$ & $\begin{array}{l}\text { Recuperação } \\
\text { e reciclagem } \\
\text { de materiais }\end{array}$ & $\begin{array}{l}\text { Quantidade percentual do total de } \\
\text { resíduos que é reciclado ou valorizado } \\
\text { (o termo valoração foi usado tanto para } \\
\text { reciclagem de resíduos secos ou } \\
\text { recuperação de resíduos orgânicos) }\end{array}$ \\
\hline
\end{tabular}




\begin{tabular}{|c|c|c|c|}
\hline N. & $\begin{array}{l}\text { Critério } \\
\text { Analítico }\end{array}$ & Indicador & Descrição \\
\hline \multicolumn{4}{|c|}{ Componentes de Estratégias Governamentais } \\
\hline $4 \mathrm{~A}$ & $\begin{array}{l}\text { Inclusão do } \\
\text { Usuário }\end{array}$ & $\begin{array}{ll}\text { Grau } & \text { de } \\
\text { inclusão } & \text { do } \\
\text { usuário } & \end{array}$ & $\begin{array}{l}\text { Grau de inclusão dos usuários de } \\
\text { serviços de resíduos sólidos } \\
\text { considerados no planejamento, } \\
\text { políticas de informação, implantação e } \\
\text { avaliação dos serviços. Os indicadores } \\
\text { foram: } \\
\text { - Leis nacionais ou locais que requerem } \\
\text { consulta pública e participação com } \\
\text { atores sociais fora das estruturas } \\
\text { burocráticas } \\
\text { - Procedimentos em vigor que } \\
\text { evidenciam a participação dos cidadãos } \\
\text { com assento nas seções sobre } \\
\text { discussões de operacionalização de } \\
\text { disposições finais ou outras unidades } \\
\text { de tratamento } \\
\text { - Satisfação do consumidor no } \\
\text { gerenciamento dos serviços de } \\
\text { resíduos sólidos no nível municipal } \\
\text { - Mecanismos de respostas entre } \\
\text { usuários dos serviços e provedores de } \\
\text { serviços } \\
\text { - Comitê de cidadãos que atuam em } \\
\text { questões de resíduos sólidos }\end{array}$ \\
\hline 4B & $\begin{array}{l}\text { Inclusão } \\
\text { Provedor }\end{array}$ & $\begin{array}{ll}\text { Grau } & \text { de } \\
\text { inclusão } & \text { do } \\
\text { provedor } & \end{array}$ & $\begin{array}{l}\text { Grau ao qual provedores de serviços de } \\
\text { resíduos não municipal do setor formal } \\
\text { privado, comunidade ou setores } \\
\text { informais estão inclusos no } \\
\text { planejamento e na implantação de } \\
\text { serviços e atividades de resíduos e } \\
\text { reciclagem: } \\
\text { - Leis nacionais ou locais que } \\
\text { encorajam parcerias público privadas, } \\
\text { participação do setor privado ou da } \\
\text { participação da comunidade organizada } \\
\text { - Organizações ou plataformas que } \\
\text { representam o setor de resíduos } \\
\text { - Evidências de proteção dos direitos do } \\
\text { setor informal que atua na cadeia de } \\
\text { resíduos sólidos }\end{array}$ \\
\hline
\end{tabular}




\begin{tabular}{|c|c|c|c|}
\hline N. & $\begin{array}{l}\text { Critério } \\
\text { Analítico }\end{array}$ & Indicador & Descrição \\
\hline & & & $\begin{array}{l}\text { - Barreiras legais para a participação do } \\
\text { setor privado no gerenciamento dos } \\
\text { resíduos } \\
\text { - Incentivos legais ou institucionais para } \\
\text { participação do setor privado no } \\
\text { gerenciamento dos resíduos }\end{array}$ \\
\hline 5 & $\begin{array}{l}\text { Sustentabilidade } \\
\text { Financeira }\end{array}$ & $\begin{array}{l}\text { População } \\
\text { usuária e } \\
\text { pagante pela } \\
\text { coleta }\end{array}$ & $\begin{array}{l}\text { Percentual do total de residências que } \\
\text { utilizam e pagam pelos serviços de } \\
\text { coleta de resíduos }\end{array}$ \\
\hline 6 & $\begin{array}{l}\text { Coerência } \\
\text { Institucional }\end{array}$ & $\begin{array}{l}\text { Grau de } \\
\text { coerência } \\
\text { institucional }\end{array}$ & $\begin{array}{l}\text { Indicadores que avaliam as políticas e o } \\
\text { grau de controle municipal: } \\
\text { - Existem compromissos do poder } \\
\text { público com a gestão sustentável de } \\
\text { resíduos sólidos? } \\
\text { - Existe um quadro político claro e } \\
\text { transparente para o planejamento e } \\
\text { implantação de práticas de } \\
\text { gerenciamento de resíduos? } \\
\text { - As autoridades retêm receitas obtidas } \\
\text { de multas e encargos ou cobram } \\
\text { encargos diretos para pagamento dos } \\
\text { serviços de resíduos? } \\
\text { - Existem serviços terceirizados de de } \\
\text { coleta de resíduos definidos, } \\
\text { supervisionados e controlados pela } \\
\text { municipalidade? }\end{array}$ \\
\hline
\end{tabular}

Fonte: Wilson et al. (2012)

Wilson et al. (2012) mencionam que quando um sistema de gerenciamento de resíduos sólidos falha, raramente é por razões técnicas e sim por razões políticas, econômicas ou institucionais.

\subsection{CONCEITOS}

Os conceitos de Resíduos Sólidos Urbanos (RSU) dos municípios estudados nesta tese foram analisados, a fim verificar se a comparação de dados quantitativos entre os municípios era compatível (Apêndice 1). 
Nos três municípios estudados, o conceito de RSU refere-se aos resíduos provenientes das atividades domésticas das residências (verticais e/ou horizontais), de pequenos estabelecimentos comerciais e de serviços, instituições públicas, limpeza urbana (varrição, resíduos de lixeiras de ruas e avenidas, poda, dentre outros) que não ultrapassam as quantidades definidas como pequeno gerador ${ }^{2}$.

Não estão inclusos no conceito de RSU dos três municípios, os seguintes tipos de resíduos: inertes de grandes geradores; perigosos de grandes geradores de atividades industriais, comerciais e de serviços; de serviço de saúde de clínicas, hospitais e unidades de saúde em geral; lodo de estação de tratamento de esgoto.

\section{Coleta de Resíduos Sólidos Urbanos}

A coleta de resíduos sólidos urbanos pode ser definida como 0 ato de retirar e recolher os resíduos gerados na fonte geradora, por equipamentos específicos para tal fim.

No Brasil, a coleta de resíduos sólidos urbanos faz uma diferenciação entre a coleta regular e a coleta seletiva, onde: (a) a coleta regular é realizada por empresas concessionárias de serviços públicos ou pela própria administração municipal, onde todos os resíduos gerados são coletados sem distinção, isto é, sem separação na fonte geradora por tipos de resíduos (orgânicos, materiais secos, inertes e rejeitos); (b) a coleta seletiva caracterizase por uma coleta diferenciada, que geralmente é realizada com outros equipamentos, em dias específicos onde o gerador separa os tipos de resíduos que serão transportados para unidades de triagem e/ou para processos produtivos de reaproveitamento e/ou reciclagem.

Na Política Nacional de Resíduos Sólidos (BRASIL, 2010), em seu artigo terceiro, a coleta seletiva foi definida como: " $V$ - coleta seletiva: coleta de

\footnotetext{
2 Limites de coleta de RSU: São Francisco: 423///coleta; Cidade do Cabo: 240///semana; São Paulo: $200 / / / d i a$.
} 
resíduos sólidos previamente segregados conforme sua constituição ou composição".

Nos países desenvolvidos, principalmente na União Europeia e na América do Norte, não existe distinção entre coleta regular e coleta seletiva pois o grau de envolvimento da sociedade no cumprimento de normas específicas para segregação dos resíduos é alto e os equipamentos que executam a coleta de resíduos são adequados para coletar os diferentes tipos de resíduos. Logo, coleta seletiva é um conceito existente no Brasil, não sendo encontrado em São Francisco e na Cidade do Cabo.

O município de São Paulo utiliza o conceito de "coleta seletiva" da Política Nacional de Resíduos Sólidos para se referir às quantidades de resíduos segregados na fonte geradora e recolhidos por prestadores de serviços (concessionárias e/ou cooperativas e associações de catadores) diferentes daqueles da coleta regular e que são enviados para processos de triagem e posteriormente, comercializados junto às industrias recicladoras e/ou produtoras. Para São Francisco, o termo utilizado pelo Departamento de Meio Ambiente equivalente ao termo e aos dados quantitativos de São Paulo é "recuperação de resíduo" (waste recovery) e para a Cidade do Cabo, o termo utilizado pelo Departamento de Resíduos Sólidos é "minimização de resíduo" (waste minimization).

\section{Reutilização}

Reutilizar ou reusar objetos, coisas integrais ou partes é um hábito comum da sociedade e consiste basicamente em "usar novamente ou dar um novo uso ou utilização" a um objeto (DICIONÁRIO AURÉLIO, 2017).

Nesta ação não existe processos físicos, químicos ou biológicos que transformam o objeto ou sua embalagem. Nesta ação, o objeto passa a ter um novo uso para seu proprietário ou quando é descartado, outro indivíduo o reaproveita, estando ele quebrado ou em bom estado de funcionamento, seja integralmente, ou partes do mesmo. 
Para Forlin (2002), a reutilização está diretamente associada a usar um objeto ou uma embalagem para a função originalmente planejada.

Para a Política Nacional de Resíduos Sólidos (BRASIL, 2010), conforme estabelecido no artigo terceiro, inciso XVIII, a reutilização é:

(...) processo de aproveitamento dos resíduos sólidos sem sua transformação biológica, física ou físico-química, observadas as condições e os padrões estabelecidos pelos órgãos competentes do Sisnama e, se couber, do SNVS e do SUASA (BRASIL, 2010).

Para o governo sul-africano a reutilização é definida como a utilização de "materiais do fluxo de resíduos novamente para um diferente propósito, sem alterar a forma ou propriedades dos materiais" (REPUBLIC OF SOUTH AFRICA, 2008).

\section{Reciclagem}

Segundo as Nações Unidas (UNSTATS, 2011), a reciclagem é definida como qualquer reprocessamento de material residual de um processo de produção e que é desviado do caminho dos resíduos, exceto o reuso de combustível.

Para a Agência Ambiental Europeia, a reciclagem é:

...(1) Um método de recuperação de recursos, envolvendo a coleta e tratamento de resíduos de um produto, para utilização como matériaprima para o fabrico do mesmo ou de um produto semelhante. (2) A estratégia de resíduos da União Europeia se distingue entre: (a) reutilização de materiais sem quaisquer alterações estruturais no material; (b) reciclagem entendida como uma reciclagem de materiais, apenas, e com uma referência às mudanças estruturais de produtos; e (c) recuperação como uma recuperação de energia (EEA, 2014).

Já a Política Nacional de Resíduos Sólidos (BRASIL, 2010) em seu artigo terceiro inciso XIV, define a reciclagem como:

o processo de transformação dos resíduos sólidos que envolve a alteração de suas propriedades físicas, físico-químicas ou biológicas, com vistas à transformação em insumos ou novos produtos, 
observadas as condições e padrões estabelecidos pelos órgãos competentes do SISNAMA, se couber, do SNVS e do SUASA (BRASIL, 2010).

Para o governo sul-africano a reciclagem é definida como:

"um processo em que os resíduos são recuperados para uso posterior, processo que envolve a separação de resíduos de um fluxo de resíduos para uso posterior e o processamento desse material separado pode ser utilizado como produto ou matéria-prima" (REPUBLIC OF SOUTH AFRICA, 2008).

Assim, a reciclagem pode ser uma alternativa viável para diminuir os problemas causados pelas quantidades de resíduos sólidos urbanos gerados diariamente no mundo e diminuir os problemas de saúde, ambientais e as perdas de recursos financeiros e naturais decorrentes do gerenciamento dos resíduos sólidos urbanos, incluindo disposições inadequadas. Entretanto, apesar de todas as vantagens mencionadas, os índices de reciclagem ainda são irrisórios em muitos municípios, nos países em desenvolvimento.

\section{Gestão e Gerenciamento}

$\mathrm{Na}$ língua portuguesa existe uma diferenciação entre gestão e gerenciamento, o que não ocorre na língua inglesa, que usa ambas palavras, com o mesmo significado, conforme apontado por Günther (2008: 10):

Por gerenciamento de resíduos sólidos se entende as etapas operacionais que vão desde a geração até a disposição final, que envolve o fluxo dos resíduos do berço ao tumulo, como se costuma dizer. Após a geração, o resíduo passa pelas etapas de acondicionamento, coleta, transporte, transbordo, tratamento (processamento ou transformação) e disposição final (colocação no solo), as quais integram o gerenciamento. Por se tratar de etapas operacionais, o gerenciamento dos resíduos sólidos sempre esteve ligado a questões da engenharia (civil, sanitária e mais recentemente ambiental), buscando solucionar o problema do afastamento do lixo produzido no meio urbano, mediante uma logística de implantação de sistemas de coleta, transporte, tratamento e disposição final como mínimo de impactos ambientais (2008: 10)

Segundo a Política Nacional de Resíduos Sólidos (BRASIL, 2010): 
$X$ - gerenciamento de resíduos sólidos: conjunto de ações exercidas, direta ou indiretamente, nas etapas de coleta, transporte, transbordo, tratamento e destinação final ambientalmente adequada dos resíduos sólidos e disposição final ambientalmente adequada dos rejeitos, de acordo com plano municipal de gestão integrada de resíduos sólidos ou com plano de gerenciamento de resíduos sólidos, exigidos na forma desta Lei;

$X I$ - gestão integrada de resíduos sólidos: conjunto de ações voltadas para a busca de soluções para os resíduos sólidos, de forma a considerar as dimensões política, econômica, ambiental, cultural e social, com controle social e sob a premissa do desenvolvimento sustentável;

Portanto, ao mencionar fatores técnicos e operacionais dos sistemas de resíduos sólidos, este trabalho irá considerar que o termo gestão é o mais pertinente para as análises das políticas públicas de resíduos sólidos e reciclagem e o termo gerenciamento será empregado para análises mais específicas da operacionalidade do sistema.

\section{Definição dos Tipos de Resíduos Sólidos nos Municípios Estudados}

Em São Francisco, nos Estados Unidos, a definição dos tipos de resíduos utilizados está apresentada no Quadro 4.

Quadro 4 Tipificação de resíduos e respectivas normativas em São Francisco, Estados Unidos

\begin{tabular}{|c|c|c|}
\hline Resíduo & Definição & Publicação \\
\hline $\begin{array}{l}\text { Resíduos } \\
\text { recicláveis }\end{array}$ & $\begin{array}{l}\text { Todo os materiais que podem ser } \\
\text { classificados, limpos e reconstituídos, a partir } \\
\text { dos programas de coleta seletiva de São } \\
\text { Francisco, com a finalidade de usar diferentes } \\
\text { formas de fabricação de um novo produto. A } \\
\text { reciclagem não inclui queima, incineração, } \\
\text { conversão ou de outra forma termicamente } \\
\text { destruindo resíduos sólidos }\end{array}$ & $\begin{array}{l}\text { Portaria } n .933-12 \\
\text { que alterou Seções } \\
1702,1703.5 \text { e } \\
1704 \text { do Código } \\
\text { Ambiental de São } \\
\text { Francisco, página } \\
5\end{array}$ \\
\hline $\begin{array}{l}\text { Resíduos } \\
\text { compostáveis }\end{array}$ & $\begin{array}{l}\text { Significa qualquer material que pode ser } \\
\text { decomposto em ou tornar-se parte de } \\
\text { composto utilizável (condicionamento do solo } \\
\text { em material) de forma segura e aceita em São } \\
\text { Francisco, como restos de alimentos, papel } \\
\text { sujo e aparas e podas de plantas. Os materiais }\end{array}$ & $\begin{array}{l}\text { Portaria } n . \text { o 100-09, } \\
\text { Seção } \\
\text { página } 5\end{array}$ \\
\hline
\end{tabular}




\begin{tabular}{|c|c|c|}
\hline Resíduo & Definição & Publicação \\
\hline & $\begin{array}{l}\text { compostáveis também podem incluir utensílios } \\
\text { de plástico descartáveis e sacos, desde que } \\
\text { sejam aqueles rotulados como compostáveis, } \\
\text { de acordo com o Regulamento de Redução de } \\
\text { Resíduos de Alimentos (n. - 295-06) e com as } \\
\text { regulamentações do Departamento de Meio } \\
\text { Ambiente }\end{array}$ & \\
\hline Rejeito & $\begin{array}{l}\text { Material que é destinado para o aterro } \\
\text { sanitário para disposição e não inclui materiais } \\
\text { recicláveis ou compostáveis. Também não } \\
\text { inclui resíduos perigosos ou material de } \\
\text { construção ou demolição }\end{array}$ & $\begin{array}{lr}\text { Portaria n. } & \text { 100-09, } \\
\text { Seção } & 1902, \\
\text { página } 7 & \end{array}$ \\
\hline $\begin{array}{l}\text { Resíduo ou } \\
\text { Lixo universal }\end{array}$ & $\begin{array}{l}\text { Resíduos domésticos em geral, também } \\
\text { contém, pilhas, lâmpadas fluorescentes ou } \\
\text { tubos, termostatos e outros itens que contém } \\
\text { mercúrio, chumbo, cádmio e outros produtos } \\
\text { químicos, bem como, dispositivos eletrônicos } \\
\text { incluindo videocassetes, microondas, telefones } \\
\text { celulares e sem fio, impressoras e rádios }\end{array}$ & $\begin{array}{l}\text { Resolução } \\
100.475\end{array}$ \\
\hline $\begin{array}{ll}\text { Resíduos } & \text { de } \\
\text { material } & \text { de } \\
\text { construção } & \text { ou } \\
\text { demolição } & \end{array}$ & $\begin{array}{l}\text { Materiais de construção gerados em atividades } \\
\text { de construção e demolição incluindo, mas não } \\
\text { se limitando a: asfalto totalmente curado, } \\
\text { concreto, tijolo, rocha, solo, madeira serrada, } \\
\text { painéis de gesso, cartão e outras embalagens } \\
\text { associadas, material de telhados, telha } \\
\text { cerâmica, carpetes, tubulações, metais, tocos } \\
\text { de árvores e outros materiais vegetais } \\
\text { resultantes do desmatamento e/ou limpeza do } \\
\text { terreno e paisagismo }\end{array}$ & $\begin{array}{lr}\text { Portaria n. } & \text { 100-09, } \\
\text { Seção } & 1902, \\
\text { página } 5 & \end{array}$ \\
\hline $\begin{array}{l}\text { Resíduos } \\
\text { comerciais }\end{array}$ & $\begin{array}{l}\text { Parcela ou qualquer quantidade de resíduos } \\
\text { gerados em propriedade privada que não é } \\
\text { uma habitação ocupada por família, incluindo } \\
\text { escolas, instituições e propriedades públicas }\end{array}$ & $\begin{array}{lr}\text { Portaria n. } & \text { 100-09, } \\
\text { Seção } & 1902, \\
\text { página } 5 & \end{array}$ \\
\hline
\end{tabular}

Fonte: County and City of San Francisco, 2012.

Os serviços de resíduos sólidos urbanos conforme a classificação da legislação sul-africana e adotada pela administração municipal da Cidade do Cabo estão apresentados no Quadro 5. 
Quadro 5 Tipificação de resíduos gerados e respectivas normativas na Cidade do Cabo, África do Sul

\begin{tabular}{|c|c|c|}
\hline Resíduo & Definição & Publicação \\
\hline $\begin{array}{l}\text { Resíduos } \\
\text { gerais }\end{array}$ & $\begin{array}{l}\text { Resíduos gerais são aqueles que não } \\
\text { representam risco ou ameaça imediata } \\
\text { para a saúde ou para o meio ambiente e } \\
\text { incluem: } \\
\text { (a) resíduo doméstico } \\
\text { (b) resíduos de construção e demolição } \\
\text { (c) resíduos comerciais } \\
\text { (d) resíduos inertes } \\
\text { (e) qualquer resíduo classificado como } \\
\text { resíduo não perigoso em termos dos } \\
\text { regulamentos estabelecidos na seção } 69 \text { e } \\
\text { inclui substâncias, materiais ou objetos } \\
\text { não perigosos dentro dos resíduos } \\
\text { comerciais, resíduos domésticos, inertes, } \\
\text { de construção e de demolição }\end{array}$ & $\begin{array}{l}\text { Gestão nacional do } \\
\text { meio ambiente. Lei } \\
\text { de resíduos nํㅗ } \\
26 / 2014\end{array}$ \\
\hline $\begin{array}{l}\text { Resíduos } \\
\text { domésticos }\end{array}$ & $\begin{array}{l}\text { São os resíduos, excluindo resíduos } \\
\text { perigosos, que são gerados em } \\
\text { instalações que são utilizadas total ou } \\
\text { principalmente para serviços residenciais, } \\
\text { educacionais, de saúde, fins esportivos ou } \\
\text { recreativos que incluem (a) resíduos de } \\
\text { jardim e parque, (b) resíduos municipais e } \\
\text { (c) resíduos alimentares }\end{array}$ & $\begin{array}{l}\text { Gestão nacional do } \\
\text { meio ambiente. Lei } \\
\text { de resíduos no } \\
26 / 2014\end{array}$ \\
\hline
\end{tabular}

Fonte: Republic of South Africa/Department Environmental Affairs, 2014.

Os serviços de RSU de São Paulo são classificados em divisíveis, indivisíveis essenciais e indivisíveis complementares, conforme a Lei Municipal 13478/03, artigo 21. Os serviços divisíveis e os tipos de resíduos sólidos gerados estão apresentados no Quadro 6. 
Quadro 6 Serviços divisíveis e lei municipal correspondente, por tipo de resíduo gerados e coletados, em São Paulo, Brasil

\begin{tabular}{|c|c|c|}
\hline Resíduo & Definição & Publicação \\
\hline I - Domiciliar & $\begin{array}{l}\text { Resíduos sólidos e materiais de varredura } \\
\text { residenciais }\end{array}$ & $\begin{array}{l}\text { Lei Municipal } \\
\text { 13478/03, art. } 22\end{array}$ \\
\hline $\begin{array}{l}\text { II - Sólidos } \\
\text { domiciliares } \\
\text { não- } \\
\text { residenciais }\end{array}$ & $\begin{array}{l}\text { Aqueles originários de estabelecimentos } \\
\text { públicos, institucionais, de prestação de } \\
\text { serviços, comerciais e industriais, entre } \\
\text { outros, com características de Classe } 2 \\
\text { (atual classe II A), conforme NBR } 10004 \\
\text { da ABNT - Associação Brasileira de } \\
\text { Normas Técnicas, até } 200 \text { (duzentos) litros } \\
\text { por dia }\end{array}$ & $\begin{array}{l}\text { Lei Municipal } \\
\text { 13478/03, art. } 22\end{array}$ \\
\hline III- Inertes & $\begin{array}{l}\text { Caracterizados como Classe } 3 \text { (atual } \\
\text { classe II B) pela norma técnica, entre os } \\
\text { quais entulhos, terra e sobras de materiais } \\
\text { de construção que não excedam a } 50 \\
\text { (cinquenta) quilogramas diários, } \\
\text { devidamente acondicionado }\end{array}$ & $\begin{array}{l}\text { Lei Municipal } \\
\text { 13478/03, art. } 22\end{array}$ \\
\hline $\begin{array}{l}\text { V - } \\
\text { Volumosos }\end{array}$ & $\begin{array}{l}\text { Restos de móveis, de colchões, de } \\
\text { utensílios, de mudanças e outros } \\
\text { similares, em pedaços, até } 200 \text { (duzentos) } \\
\text { litros }\end{array}$ & $\begin{array}{l}\text { Lei Municipal } \\
\text { 13478/03, art. } 22\end{array}$ \\
\hline $\begin{array}{l}\text { VI Feiras } \\
\text { livres }\end{array}$ & $\begin{array}{l}\text { Originados de feiras livres e mercados, } \\
\text { desde que corretamente acondicionados }\end{array}$ & $\begin{array}{l}\text { Lei Municipal } \\
\text { 13478/03, art. } 22\end{array}$ \\
\hline VII Outros & $\begin{array}{l}\text { Outros resíduos que vierem a ser } \\
\text { definidos por regulamento pela Autoridade } \\
\text { Municipal de Limpeza Urbana - AMLURB }\end{array}$ & $\begin{array}{l}\text { Lei Municipal } \\
\text { 13478/03, art. } 22\end{array}$ \\
\hline
\end{tabular}

Fonte: AMLURB, 2017.

\section{Elementos de um Sistema de Gerenciamento de Resíduos Sólidos}

\section{Urbanos}

Os elementos de um sistema de gerenciamento de resíduos sólidos urbanos contemplam diversas etapas operacionais: geração, acondicionamento, coleta, transporte, tratamento, até sua disposição final, envolvendo diferentes atores sociais, desde o cidadão (gerador), como os gestores dos serviços de limpeza urbana, empresas privadas concessionárias, 
organizações sociais que atuam na cadeia de resíduos, conforme apresentado na Figura 1.

Figura 1 Etapas do sistema de gerenciamento de resíduos sólidos urbanos

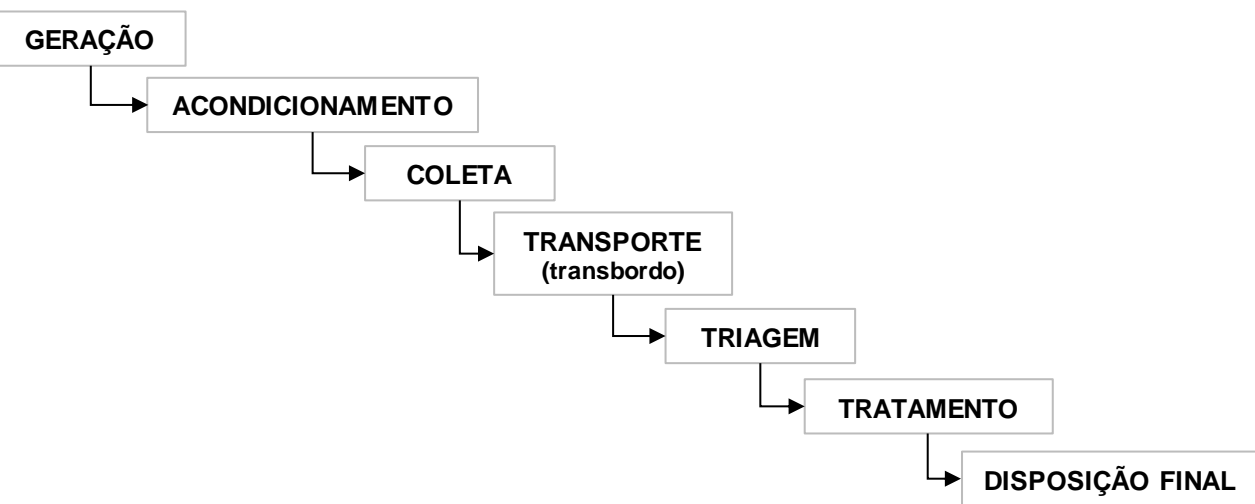

Elaboração: a autora

Entretanto, um sistema de gerenciamento de RSU bem sucedido, isto é, com impactos negativos mínimos à saúde pública, ao meio ambiente, à economia e aos aspectos socioculturais não pode ser visto como um sistema isolado.

O sistema de gerenciamento de resíduos sólidos urbanos deve estar integrado aos outros elementos de gestão pública (planos, programas, instrumentos legais, ações operacionais, etc.) de diversas áreas (saúde, educação, saneamento, ambiente, economia, transporte, desenvolvimento social, patrimônio, cultura, segurança e outros) para garantir seus objetivos fundamentais: contribuir com a manutenção da qualidade de vida, da saúde, a proteção dos recursos naturais, o respeito aos aspectos sociais e culturais, a sustentabilidade financeira e econômica. Alterações na gestão municipal em qualquer área pode desencadear ajustes necessários no gerenciamento dos RSU. Pode-se mencionar como exemplo: a adoção de coleta contenerizada para todo o território de São Paulo, acarretará ajustes necessários nas áreas de transporte, de desenvolvimento urbano, obras, na medida que haverá necessidade de se remodelar ou projetar locais dentro de edificações locais específicos para armazenar os contêineres, dentre outros. A Figura 2 ilustra a 
inter-relação do sistema de gerenciamento de resíduos sólidos urbanos com as demais áreas da gestão municipal.

Figura 2 Inter-relação do sistema de gerenciamento de resíduos sólidos urbanos com outros sistemas municipais

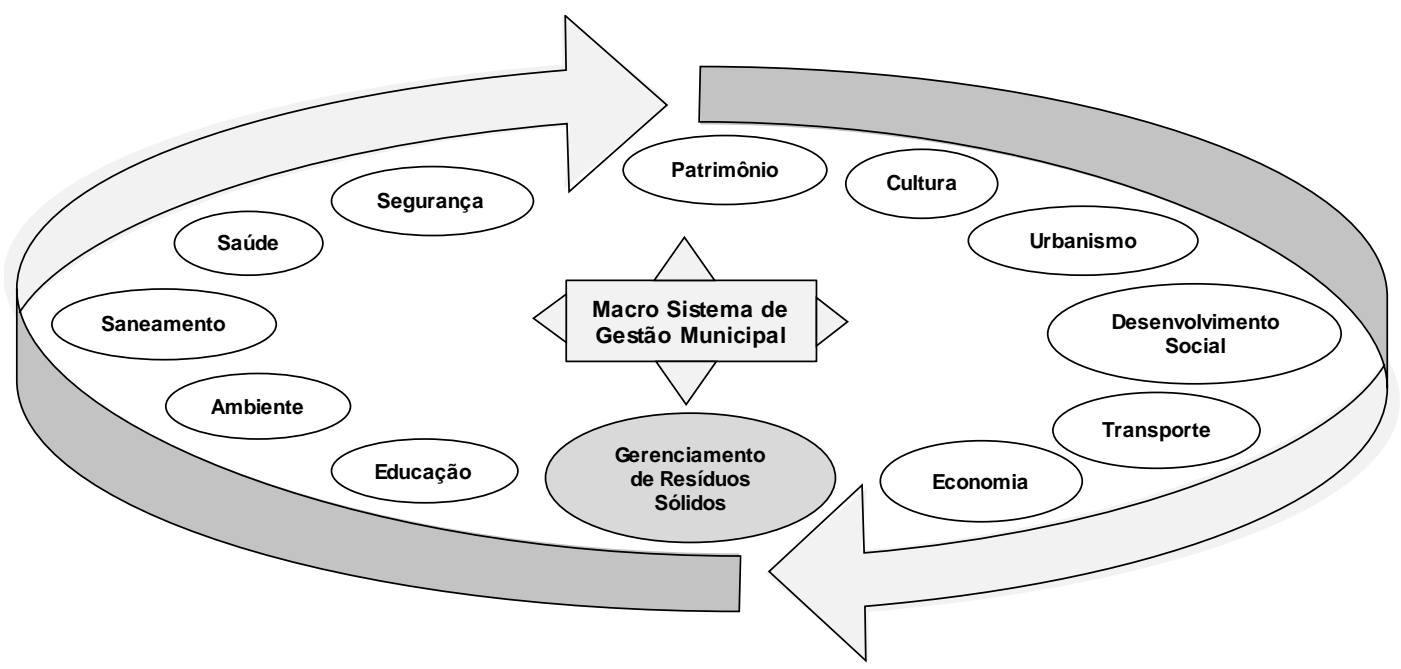

Elaboração: a autora

O Banco Mundial em seu relatório What a Waste: A Global Review of Solid Waste Management (WORLD BANK, 2012) menciona que gerenciar os resíduos sólidos urbanos é uma enorme tarefa que envolve: (i) retirar os resíduos dos locais de geração e fazê-lo da maneira mais econômica, social e ambiental possível; (ii) sempre é uma responsabilidade do poder público local; (iii) o poder público local necessita estar capacitado para diversas tarefas para operacionalizar o sistema (aquisições e licitações, operacionalização das tarefas, gestão de orçamentos, gerenciamento das finanças, profissionais capacitados, etc.); (iv) há necessidade da existência de um forte contrato social entre o município e a comunidade.

Esta concepção de sistema de RSU integrado às demais áreas da gestão municipal já foi explorada na literatura internacional pelo relatório das Nações Unidas (UN HABITAT, 2010) e por Wilson et al. (2012) que investigaram 
modelos de gestão e gerenciamento de sucesso de RSU. Ambos trabalhos mencionam o modelo desenvolvido por Van De Klundert e Anschütz (2001) para países em desenvolvimento, como um modelo de referência para as boas práticas de sistemas de resíduos sólidos urbanos: Gerenciamento Sustentável Integrado de Resíduos (GSIR). Van De Klundert e Anschütz (2001) desenvolveram o GSIR para cidades onde os problemas sanitários causados pela gestão e o gerenciamento inadequados de resíduos sólidos urbanos eram significativos e necessitam de intervenções imediatas. O modelo GSIR se baseia na seguinte visão:

(...) a maioria dos problemas de gerenciamento de resíduos tem que ver com algo diferente - ou mais - do que dinheiro e equipamento. Alguns problemas têm a ver com a atitude e o comportamento dos cidadãos, da equipe de gerenciamento de resíduos, empresas privadas e dos catadores de lixo. Outros problemas são causados ou são mais graves por fatores que não são técnicos ou financeiros, mas se relacionam com capacidades gerenciais, 0 quadro institucional, o meio ambiente ou o contexto social e/ou cultural. Nesses casos, não é dinheiro ou equipamentos que fornecem soluções, mas mudam as condições sociais, institucionais, legais ou políticas" (VAN DE KLUNDERT E ANSCHÜTZ, 2001: 10)

Esta visão do modelo elencou quatro princípios básicos que norteiam as boas práticas de gerenciamento de resíduos sólidos urbanos: equidade, eficácia, eficiência e sustentabilidade, cujas justificativas estão apresentadas no

\section{Quadro 7.}


Quadro 7 Princípios básicos do gerenciamento sustentável integrado de resíduos (GSIR)

\begin{tabular}{|c|c|c|}
\hline \multicolumn{2}{|r|}{ Princípios Básicos } & Justificativa \\
\hline & $\begin{array}{l}\text { Todos os cidadãos têm } \\
\text { direito a um sistema de } \\
\text { gestão adequado de } \\
\text { resíduos sólidos por } \\
\text { razões de saúde e } \\
\text { ambiental }\end{array}$ & $\begin{array}{l}\text { A poluição em uma parte da cidade afeta o resto da } \\
\text { cidade, incluindo o seu abastecimento de água e ar. A } \\
\text { poluição "viaja" sob a forma de doenças transmissíveis } \\
\text { por vetores (moscas, insetos, ratos), pelo ar e pela } \\
\text { água. } \\
\text { As áreas poluídas contribuem com condições de vida } \\
\text { precárias, que por sua vez, promovem o conflito social } \\
\text { e as atividades antigovernamentais. O abandonado é } \\
\text { um símbolo de um serviço público falido. Bairros } \\
\text { imundos podem afetar a economia da cidade e inibir o } \\
\text { desenvolvimento. Os investidores não investem em } \\
\text { lugares sujos, poluídos e com foco de doenças. Os } \\
\text { trabalhadores têm baixa produtividade em ambientes } \\
\text { poluídos. }\end{array}$ \\
\hline & $\begin{array}{l}\text { O modelo de } \\
\text { gerenciamento de } \\
\text { resíduos deve } \\
\text { promover a remoção } \\
\text { de todos os resíduos } \\
\text { sólidos para locais } \\
\text { ambientalmente } \\
\text { corretos }\end{array}$ & $\begin{array}{l}\text { A eficácia de um serviço é a medida em que os } \\
\text { objetivos do serviço foram atendidos na prática. Por } \\
\text { exemplo: o serviço de varredura é eficaz se as ruas } \\
\text { estiverem limpas. A eficácia da gestão de resíduos, em } \\
\text { geral, significa que todos os resíduos são removidos, } \\
\text { conforme planejado e todos os materiais passíveis de } \\
\text { reciclagem são recuperados. Quando a eficácia é } \\
\text { limitada ao centro da cidade, áreas turísticas ou } \\
\text { distritos de negócios, o sistema geral de gerenciamento } \\
\text { de resíduos não é totalmente efetivo. As partes menos } \\
\text { visíveis da cidade são tão importantes quanto (às } \\
\text { vezes mais importantes do que) os visíveis. }\end{array}$ \\
\hline 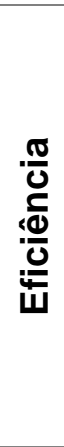 & $\begin{array}{l}\text { A gestão de todos os } \\
\text { resíduos é feita com } \\
\text { maximização dos } \\
\text { benefícios, } \\
\text { minimização dos } \\
\text { custos e otimização } \\
\text { dos uso de recursos, } \\
\text { considerando a } \\
\text { equidade, a eficácia e } \\
\text { a sustentabilidade }\end{array}$ & $\begin{array}{l}\text { O serviço é eficiente quando os benefícios das ruas } \\
\text { limpas estão equilibrados e todos os beneficiários } \\
\text { pagam valor viável para mantê-lo. Dessa forma, } \\
\text { usando a combinação ideal de mão-de-obra, dinheiro, } \\
\text { equipamentos, máquinas e gerenciamento. }\end{array}$ \\
\hline
\end{tabular}




\begin{tabular}{|c|c|c|}
\hline \multicolumn{2}{|r|}{ Princípios Básicos } & Justificativa \\
\hline 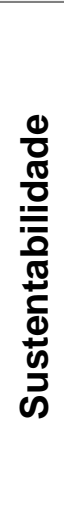 & $\begin{array}{l}\text { O sistema de gestão } \\
\text { de resíduos é } \\
\text { adequado às } \\
\text { condições locais, viável } \\
\text { a partir de uma } \\
\text { abordagem técnica, } \\
\text { ambiental, social, } \\
\text { econômica, financeira, } \\
\text { institucional e política. } \\
\text { Mantém-se ao longo } \\
\text { do tempo sem esgotar } \\
\text { os recursos que utiliza }\end{array}$ & $\begin{array}{l}\text { Sustentabilidade se refere às formas como os recursos } \\
\text { são utilizados e a forma como estes se enquadram no } \\
\text { contexto da cultura da sociedade local. Os recursos } \\
\text { podem ser humanos (mão de obra), materiais } \\
\text { (equipamentos) ou recursos naturais (água, ar, solo). } \\
\text { Inclui a distinção entre o uso de recursos renováveis e } \\
\text { não renováveis. Também se refere à interação de } \\
\text { todos os aspectos, como sociais, políticos, técnicos e } \\
\text { ambientais. Um sistema é considerado sustentável } \\
\text { quando seu funcionamento não afeta as gerações } \\
\text { futuras. }\end{array}$ \\
\hline
\end{tabular}

Fonte: adaptado. Van de Klundert e Anschütz, 2001: 11

A partir dos princípios básicos, o modelo GSIR identificou três dimensões do sistema de RSU que conduzem à sustentabilidade: (i) os atores sociais e/ou as partes interessadas na gestão dos resíduos; (ii) os elementos técnicos do sistema de resíduos; e (iii) os aspectos do contexto local que devem ser considerados nas ações de planejamento e avaliação de um sistema de gestão de resíduos. A Figura 7 mostra a integração das três dimensões. 
Figura 3 Dimensões do modelo gerenciamento sustentável integrado de resíduos sólidos

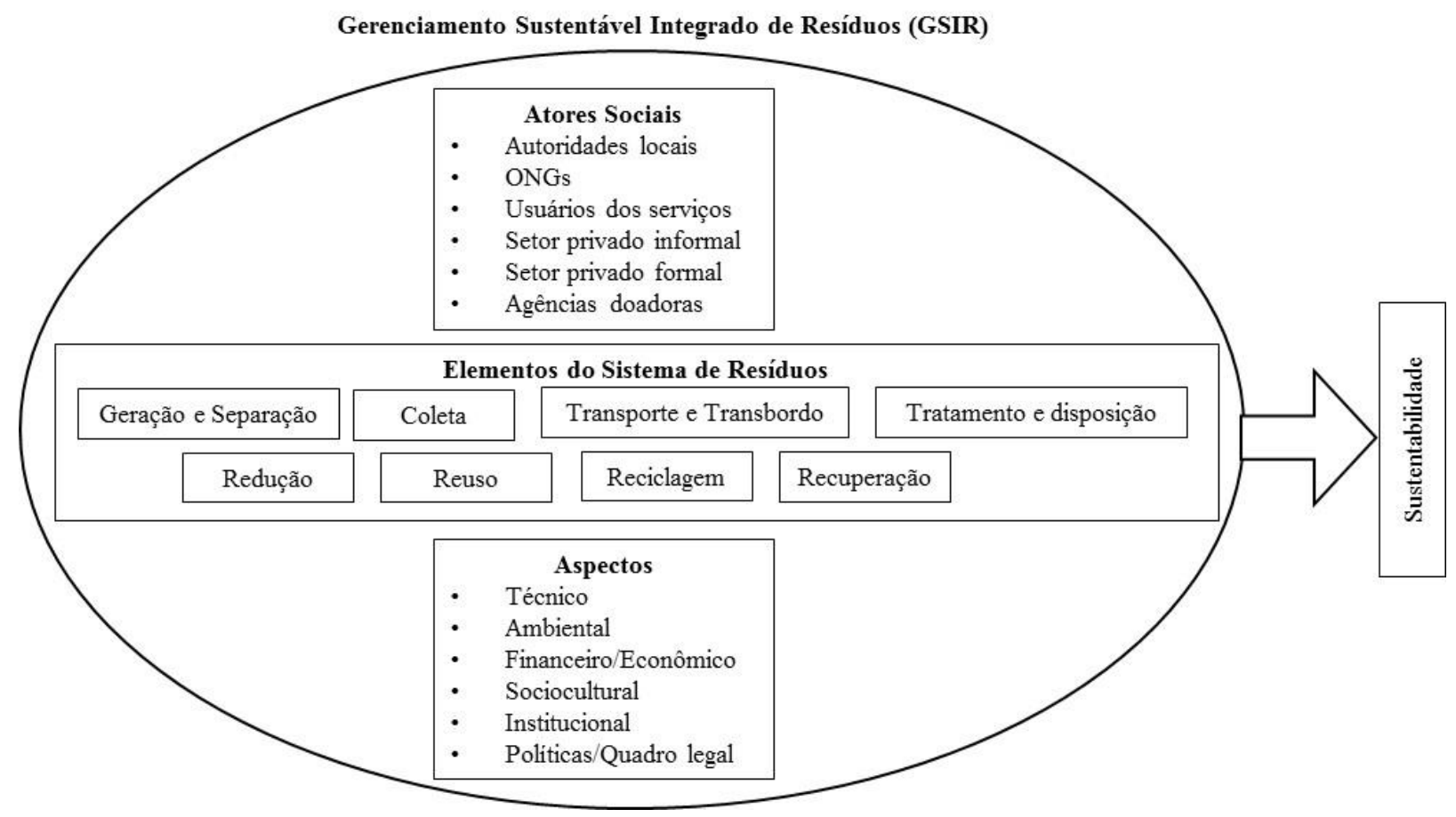

Fonte: Van de Klundert e Anschütz, 2001

Para a dimensão dos atores sociais, Van De Klundert e Anschütz (2001) identificaram que, apesar dos interesses distintos no gerenciamento dos resíduos, os atores têm papel fundamental na persuasão das comunidades e podem contribuir para tomadas de decisões, portanto, devem ser incluídos nos processos de planejamento, nas mudanças de objetivos de planos de gestão de resíduos e nas alterações de processos. Os autores destacam como ator social estratégico o setor informal da reciclagem nas cidades de países do Sul.

Os elementos técnicos de um sistema de resíduos seriam uma combinação entre cada um (geração, separação, redução, coleta, reuso, transporte, transbordo, reciclagem, recuperação, tratamento e disposição), sempre em constante mudança, com participações igualitárias no processo de gerenciamento. Portanto, planos de gerenciamento de resíduos devem 
enxergar todos os fluxos dos diversos materiais presentes e criar uma estratégia integrada de gerenciamento, considerando as características dos locais geradores.

A terceira dimensão do modelo GSIR, os Aspectos, segundo Van De Klundert e Anschütz (2001), pode ser dividida em seis itens que devem ser considerados ao se avaliar um sistema de resíduos sólidos existente ou planejado. Segundo os autores, estes aspectos proporcionam um equilíbrio de prioridades e ajudam a criar medidas para alcançar os resultados. Os seis aspectos considerados pelo modelo são:

- Aspectos ambientais: são os efeitos que o gerenciamento dos resíduos sólidos causa nos recursos naturais (água, solo, ar), na saúde pública, na conservação de recursos naturais não renováveis e no controle da poluição;

- Aspectos políticos e jurídicos: endereçam os limites das condições existentes dos sistemas de gerenciamento de resíduos existentes. Determinam as prioridades e metas, os papéis das instituições e suas competências, o quadro legal e regulador e os processos para tomada de decisões;

- Aspectos socioculturais: se referem à influência da cultura na geração e gestão de resíduos nas residências, empresas e instituições e como a comunidade participa na gestão dos resíduos, quais são as relações entre os grupos e as comunidades, entre pessoas de várias idades, sexo, etnia e as condições sociais dos trabalhadores de resíduos;

- Aspectos institucionais: estão associados às estruturas organizacionais, os procedimentos, aos métodos aplicados, à capacidade disponível das instituições, como se dá o envolvimento dos atores e à importância do planejamento;

- Aspectos econômicos e financeiros: referem-se ao orçamento e despesas dos custos do sistema de gestão de resíduos em si e em 
relação à economia local, regional, nacional e internacional. Outras questões abordadas neste aspecto são: privatização, recuperação e redução de custos, impacto dos serviços ambientais nas atividades econômicas, o mercado de commodities, como as infraestruturas de reciclagem estão organizadas, a eficiência dos sistemas municipais de gestão de resíduos sólidos, às dimensões macroeconômicas do uso de recursos naturais, à conservação e à geração de renda;

- Aspectos técnicos: estão associados a todos os elementos executivos do sistema de resíduos, tais como: equipamentos, ferramentas, instalações, funcionamento, projetos de novas tecnologias e/ou reformas e ampliações. E como todos estes elementos juntos, em funcionamento, mantem a limpeza das cidades.

Apesar de todo os elementos de um sistema de resíduos sólidos urbanos serem fundamentais para sua viabilidade técnica, econômica, ambiental e sociocultural, este trabalho se propõe a investigar parte do sistema: a coleta que retira os resíduos dos aterros sanitários que podem ser reaproveitados e/ou reciclados (Figura 4).

Figura 4 Foco da investigação da pesquisa no sistema de gerenciamento de resíduos sólidos urbanos

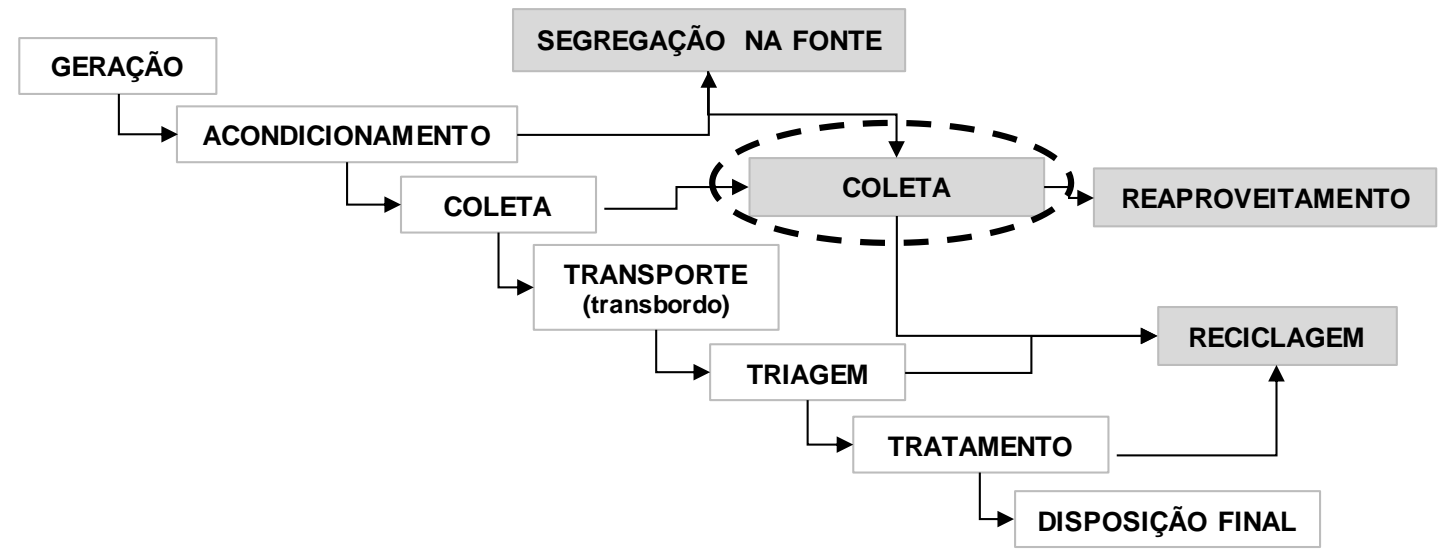

Elaboração: a autora 
Esta investigação se propõe a verificar a existência de segregação de resíduos sólidos urbanos domiciliares na fonte, como são coletados e encaminhados para reaproveitamento, reuso e/ou reciclagem. Quanto maior a participação do gerador na segregação na fonte, maiores são as chances de as administrações municipais aumentarem suas taxas de reciclagem.

\subsection{RESÍDUOS SÓLIDOS URBANOS, COLETA SELETIVA, REUTILIZAÇÃO E RECICLAGEM NO MUNDO}

A partir dos dados da UNSTATS (2011) apresentados na Figura 5, observa-se que os países com maiores percentuais de reciclagem de resíduos sólidos urbanos são, em geral, os países desenvolvidos. Tanto na Europa como na América do Norte, os países com melhores percentuais de reciclagem consideram os resíduos como uma fonte de energia e de subprodutos para processos produtivos. Um importante fator que impulsionou a reciclagem de RSU, no mundo, foi a carência das áreas para aterros sanitários.

Nos países desenvolvidos, as instalações utilizadas para processar (separar, tratar, reciclar) os resíduos são unidades com grandes investimentos tecnológicos e financeiros, onde os governos locais aplicam muitos recursos humanos e financeiros em campanhas de sensibilização para a separação dos resíduos na fonte geradora.

Entretanto, mesmo com maiores percentuais de reciclagem, os países desenvolvidos possuem desafios constantes para manter os percentuais alcançados e/ou aumentá-los, pois há uma tendência mundial de aumento da geração de resíduos sólidos (WORLD BANK, 2012; ISWA, 2011).

Em 2020, a OCDE estima que poderemos gerar $45 \%$ a mais resíduos do que gerados em 1995. Obviamente, temos de inverter esta tendência, se não quisermos ficar submersos nos resíduos. Mas a imagem não é totalmente sombria. Das ações do Programa de Ação Ambiental da União Europeia foi identificado que a prevenção e gestão de resíduos é uma das quatro prioridades principais. O objetivo primário é dissociar a geração de resíduos da atividade 
econômica tanto que o crescimento da União Europeia não conduza à geração de mais resíduos e há sinais de que isso está começando a acontecer. Na Alemanha e nos Países Baixos, por exemplo, geração de resíduos sólidos urbanos caiu durante a década de 1990 (ISWA, 2011: 22)

Figura 5 Reciclagem de resíduos sólidos urbanos no mundo, em 2011

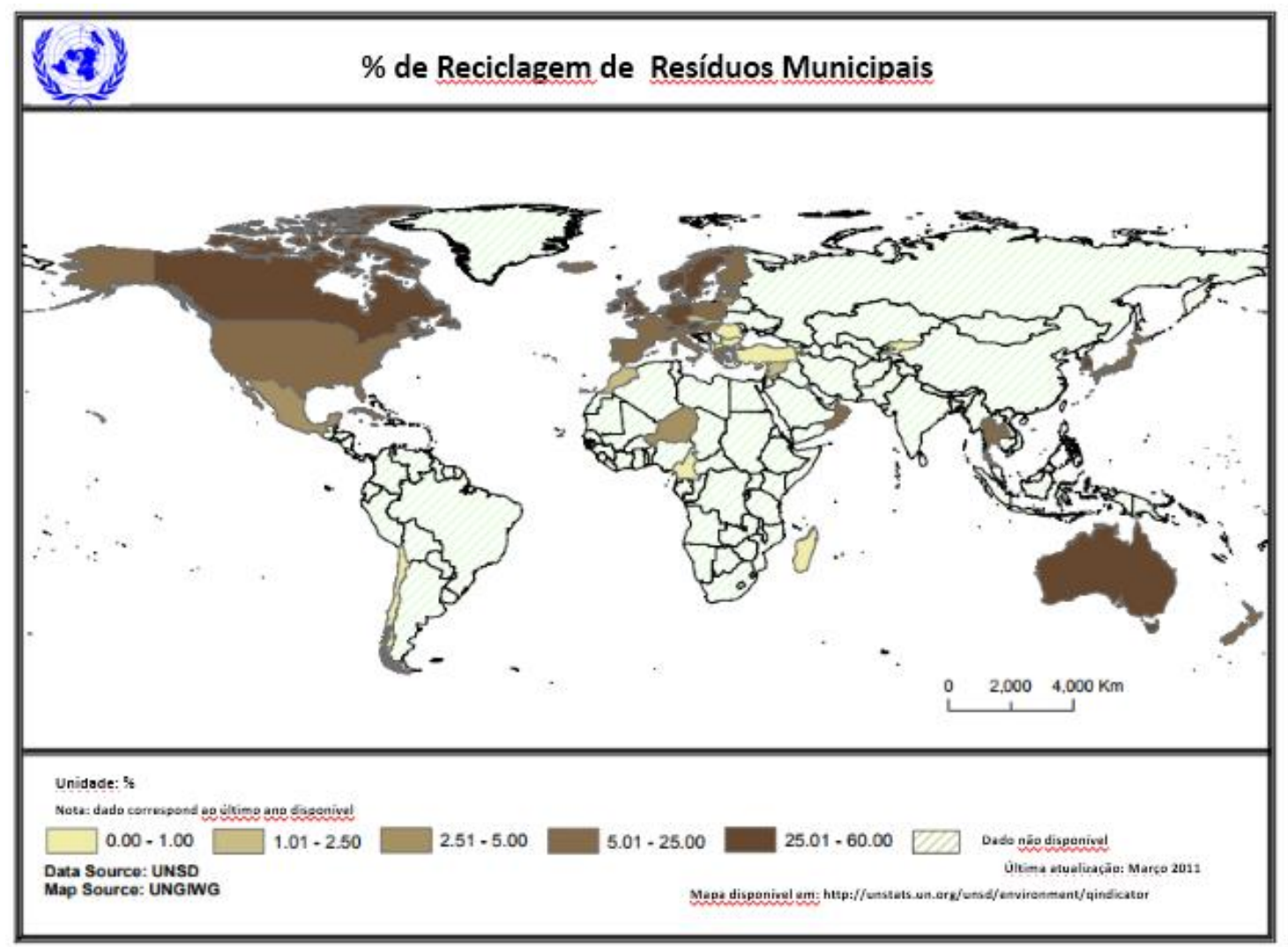

Fonte: UNSTATS, 2011

O desafio é ainda maior, para os governos locais de países em desenvolvimento, como o Brasil e África do Sul.

A crescente geração de RSU e os reduzidos percentuais de reciclagem são problemas universais de saúde e sustentabilidade socioambiental que permanecem rondando as melhores técnicas de planejamento urbano e saneamento ambiental. Em muitas localidades de países em desenvolvimento, 
o tema gerenciamento de resíduos sólidos urbanos é tratado isoladamente dos assuntos de planejamento (ISWA, 2011).

Entretanto, em algumas regiões, como na Europa e na América do Norte, a cadeia de valor dos RSU já foi invertida. As prioridades estão focadas em técnicas de minimização de resíduos, onde o produtor tem responsabilidade por produzir bens mais duráveis, aptos a serem consertados e ambientalmente adequados, através dos instrumentos legais definidos como Responsabilidade Estendida do Produtor (ERP). Os cidadãos também são incentivados a gerar menores quantidade de RSU e a pagar taxas especificas, quando geram mais resíduos do que o estabelecido nos instrumentos legais em vigor.

O conceito de Resíduo Zero ou Zero Waste, onde o foco é reaproveitar, reutilizar e reciclar ao máximo, de modo que sejam enviadas quantidades mínimas para aterros sanitários tem se disseminado no mundo. Entretanto, nos países de renda baixa ou média, como o Brasil, o foco ainda é atingir a coleta de resíduos sólidos urbanos ampla e acessível para todos e promover a correta disposição final.

Paralelamente, nos países em desenvolvimento, a coleta seletiva formal ou informal tem uma importante participação dos setores informais (Cooperativa ou Associação de Catadores e catadores independentes) conforme apontado pela publicação do International Solid Waste Association (ISWA):

Em muitas cidades ao redor do mundo e especialmente naquelas de rápido crescimento é considerável o número de pessoas que se mantem financeiramente bem como suas famílias com a recuperação de materiais reutilizáveis e recicláveis dos materiais considerado resíduos por outros. (ISWA, 2011 p:22)

O ISWA (2011) ainda aponta que o setor informal de coleta seletiva vem se organizando em nível global e que é um movimento crescente na Ásia e na América Latina. O ISWA ressalta as estimativas do Banco Mundial que "estima que $1 \%$ da população mundial ou 50 milhões de pessoas vivem das coletas 
seletivas informais". O relatório ainda aponta a importância do setor informal para a reciclagem:

(...) deve-se sempre ter em mente que um dos principais desafios da gestão de resíduos nos países em desenvolvimento é trabalhar com o setor de reciclagem informal existente para melhorar os meios de vida, condições de trabalho e eficiência de reciclagem (ISWA, 2011 p: 22)

\section{Estados Unidos}

Segundo o Relatório Gestão Sustentável Avançada de Materiais (USEPA, 2015), a reciclagem traz vantagens ambientais em todo o ciclo de vida dos produtos: ao se utilizar materiais em desuso ou indesejáveis como matéria prima de processos industriais são produzidas menores quantidades de gases do Efeito Estufa e também há a criação de mais empregos e maior dinamização econômica.

A composição dos RSU nos Estados Unidos apresentada na Figura 6 mostra que os resíduos são compostos por materiais com potencial para reciclagem ou aproveitamento térmico (combustão ou incineração), em maior percentual do que os resíduos orgânicos ou úmidos (USEPA, 2014). 
Figura 6 Composição dos resíduos sólidos urbanos nos Estados Unidos em 2013

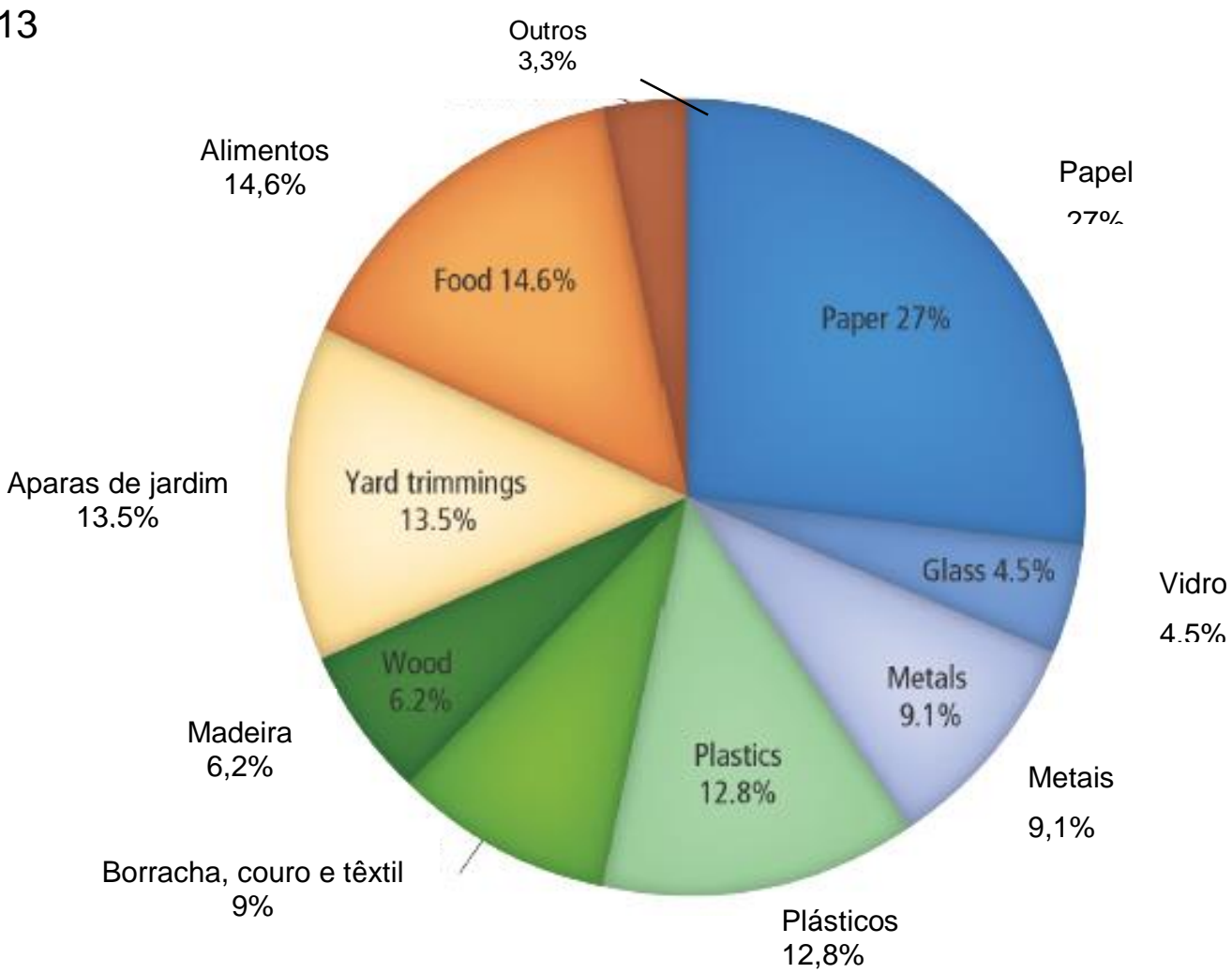

Fonte: USEPA, 2014

O gerenciamento dos RSU nos Estados Unidos (Figura 7) está baseado na hierarquia que considera 4 componentes: (i) redução na fonte incluindo a reutilização de produtos e a compostagem de aparas de jardim e dos quintais; (ii) Reciclagem, incluindo compostagem feita pela comunidade, fora do local de geração; (iii) combustão (incineração) com recuperação de energia; e (iv) tratamento e disposição final em aterros sanitários (USEPA, 2014). 
Figura 7 Hierarquia do gerenciamento dos resíduos sólidos nos Estados Unidos, em 2013

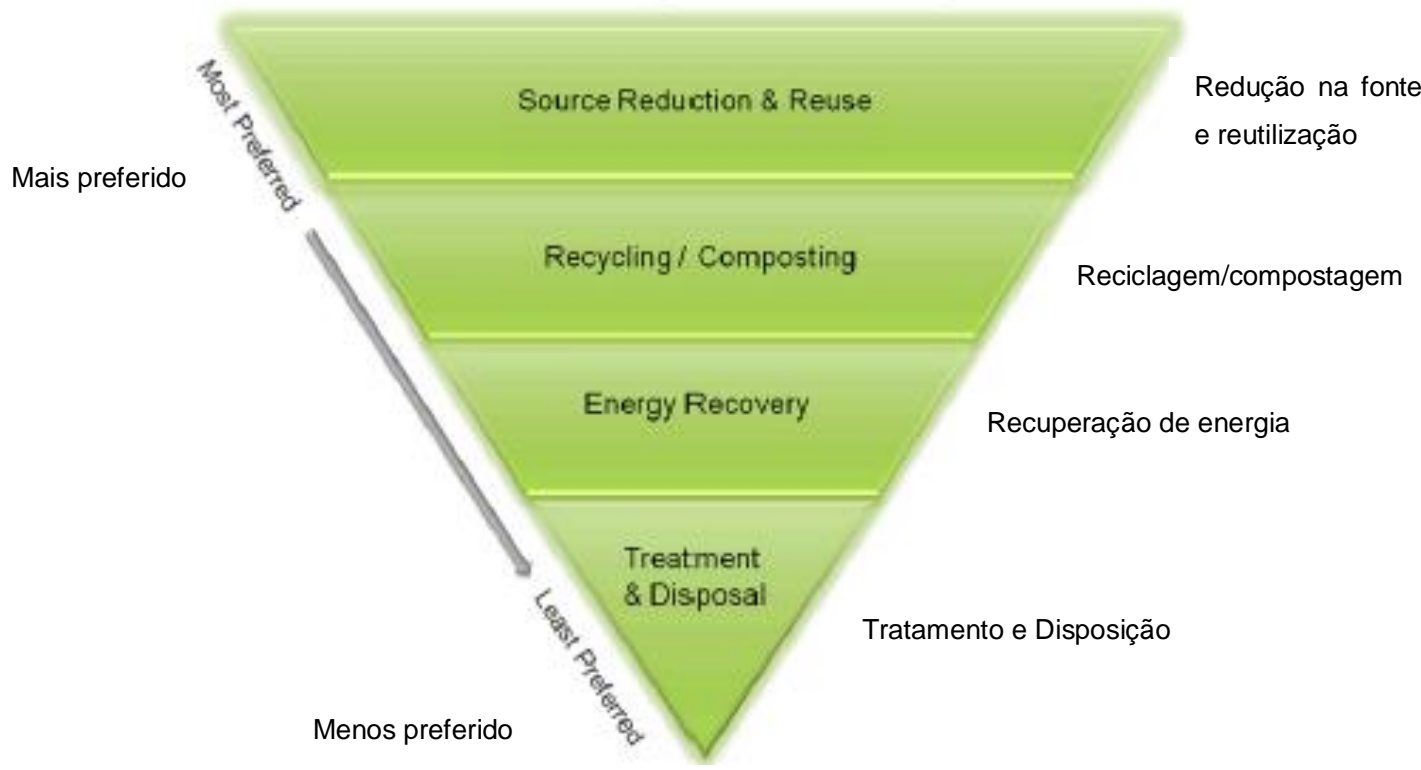

Fonte: USEPA, 2014

Do total de RSU (254 milhões de toneladas) gerados nos Estados Unidos em $2013,87,20$ milhões de toneladas (34,3\%) foram recicladas e compostadas, 32,70 milhões de toneladas $(12,9 \%)$ foram incineradas em processos com recuperação de energia e 134,30 milhões de toneladas $(52,8 \%)$ foram destinados a aterros sanitários (USEPA, 2014) (Figura 8 e Tabela 3). 
Figura 8 Taxas de reciclagem de resíduos sólidos urbanos, nos Estados Unidos, entre 1960 e 2013

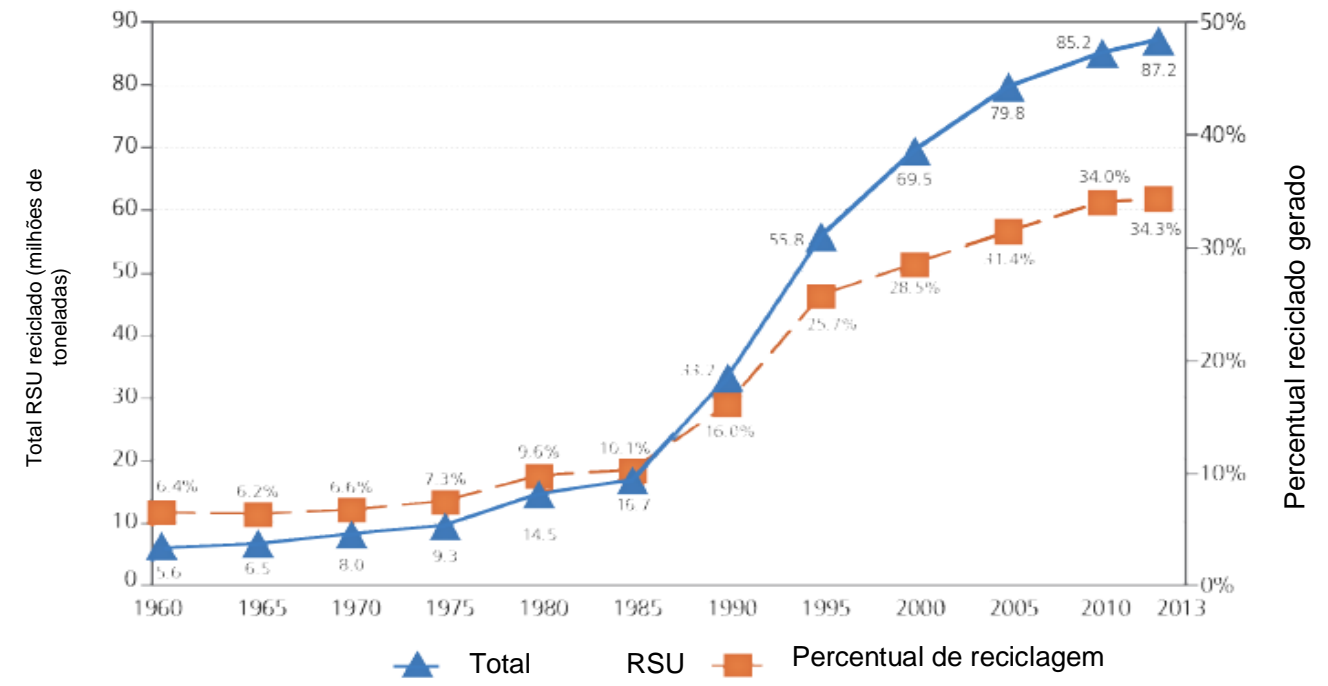

Fonte: USEPA, 2014

Tabela 3 Percentual de resíduos sólidos urbanos reciclados nos Estados Unidos, entre 1960 e 2013

\begin{tabular}{|c|c|c|c|c|c|c|c|c|c|c|}
\hline \multirow{2}{*}{ Etapas } & \multicolumn{10}{|c|}{ Percentual do Total Gerado (\%) } \\
\hline & 1960 & 1970 & 1980 & 1990 & 2000 & 2005 & 2009 & 2011 & 2012 & 2013 \\
\hline Geração & 100,00 & 100,00 & 100,00 & 100,00 & 100,00 & 100,00 & 100,00 & 100,00 & 100,00 & 100,00 \\
\hline $\begin{array}{l}\text { Total de } \\
\text { Materiais } \\
\text { Recuperados: }\end{array}$ & 6,40 & 6,60 & 9,60 & 16,00 & 28,50 & 31,40 & 33,80 & 34,70 & 34,50 & 34,30 \\
\hline Reciclagem & 6,40 & 6,60 & 9,60 & 14,00 & 21,80 & 23,30 & 25,30 & 26,50 & 26,00 & 25,50 \\
\hline $\begin{array}{l}\text { Compostagem } \\
\text { (1) }\end{array}$ & $\cdots$ & $\ldots$ & $\cdots$ & 2,00 & 6,70 & 8,10 & 8,50 & 8,20 & 8,50 & 8,80 \\
\hline $\begin{array}{l}\text { Recuperação } \\
\text { após descarte: }\end{array}$ & 93,60 & 93,40 & 90,40 & 84,00 & 71,50 & 68,60 & 66,20 & 65,30 & 65,50 & 65,70 \\
\hline $\begin{array}{l}\text { Combustão } \\
\text { com } \\
\text { Recuperação } \\
\text { de Energia }^{(2)}\end{array}$ & 0 & 0,30 & 1,80 & 14,20 & 13,90 & 12,50 & 11,90 & 12,70 & 12,80 & 12,90 \\
\hline $\begin{array}{l}\text { Envio Aterros, } \\
\text { outras } \\
\text { Disposições }{ }^{(3)}\end{array}$ & 93,60 & 93,10 & 88,60 & 69,80 & 57,60 & 56,10 & 54,40 & 52,60 & 52,70 & 52,80 \\
\hline
\end{tabular}

Fonte: USEPA, 2014.

Nota: (...) Dado não disponível. (1) Compostagem de aparas de jardim, alimentos e outros materiais orgânicos RSU. Não inclui compostagem de quintal. (2) Inclui combustão de resíduos sólidos urbanos 
em incinerador ou resíduos usados como combustível e combustão com recuperação de energia provenientes de matérias primas separadas dos resíduos sólidos urbanos (por exemplo, paletes de madeira e combustível derivado de pneus). 2013 inclui 29.500 resíduos sólidos urbanos, 510 de madeira e 2.650 pneus (1.000 toneladas). (3) Descarte após a combustão de recuperação, menos com recuperação de energia. Descartes incluem combustão sem recuperação de energia. Detalhes podem não corresponder aos totais devido a arredondamentos.

A Agência de Proteção Ambiental dos Estados Unidos (USEPA, 2014) registrou um crescimento do valor "per capita" gerado por dia de resíduos sólidos urbanos em todo o país: em 1960 um americano gerou 1,21 kg/dia e, em 2013, gerou $1,99 \mathrm{~kg} / \mathrm{dia}$, aumento de $61 \%$.

\section{Europa}

Segundo a Agência Ambiental Europeia (EEA, 2013), cerca de 60\% dos resíduos sólidos gerados na Europa em 2010 eram constituídos por resíduos minerais e solo. Já os resíduos compostos por metal, papel e papelão, madeira, produtos químicos e resíduos médicos e animal, e resíduos vegetais representaram entre $2 \%$ e $4 \%$ do total. Os resíduos sólidos urbanos representaram cerca de $10 \%$ do total gerado.

Em 2012, a quantidade per capita de resíduos sólidos urbanos na Europa foi contabilizada em 481 quilos, ou 1,31 kg/dia (EEA, 2013).

$\mathrm{Na}$ União Europeia, a legislação de gerenciamento dos resíduos sólidos (Waste Framework Directive, 2008) determina, em linhas gerais, que se deve prevenir, ou seja, não gerar os resíduos, separá-los para a reutilização, posteriormente encaminhar para a reciclagem ou recuperação e, em último caso, a disposição em aterros sanitários (EEA, 2013) (Figura 9). 
Figura 9 Hierarquia de resíduos da União Europeia

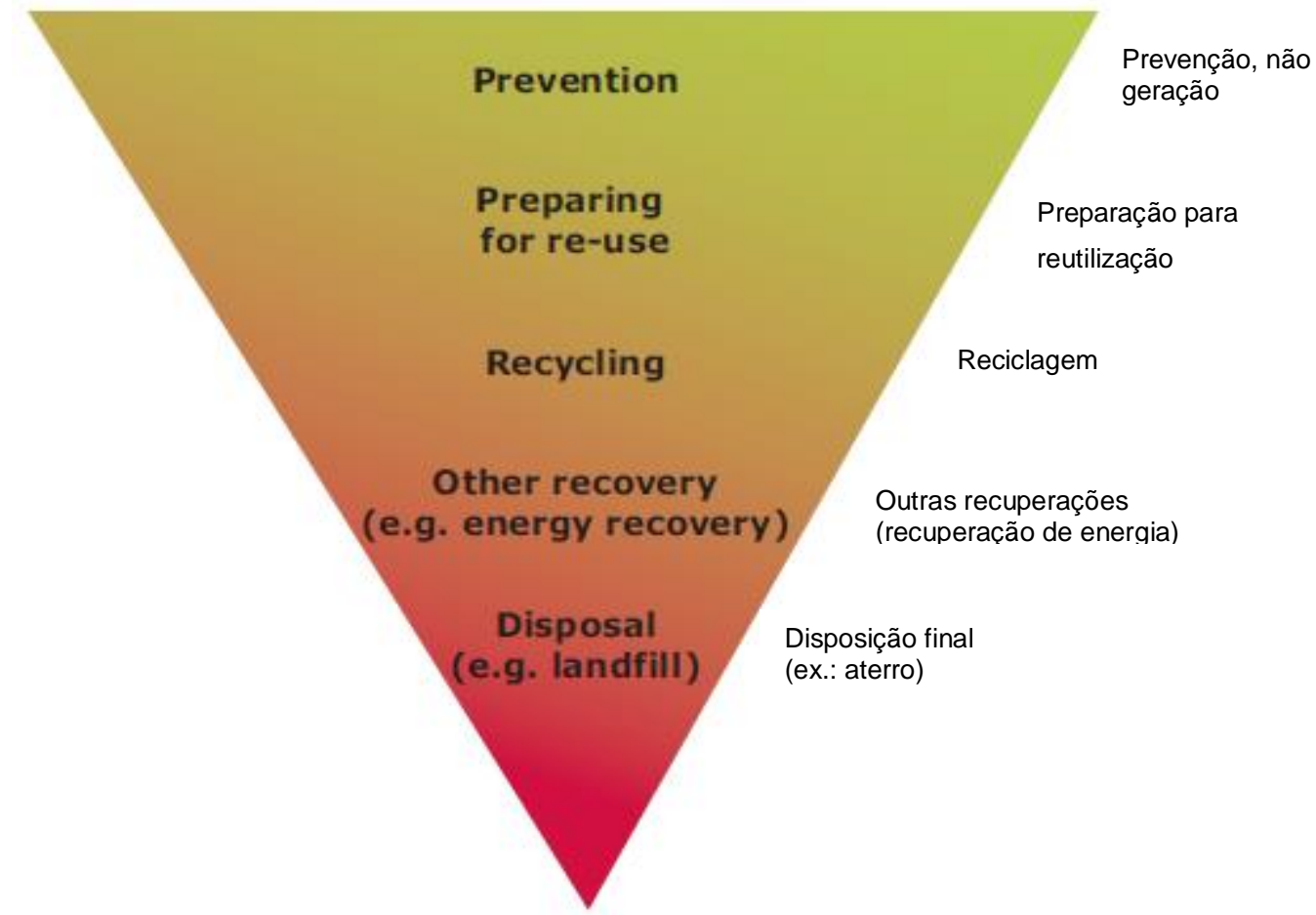

Fonte: EEA, 2013

Os percentuais de reciclagem de RSU na União Europeia, em 2012, ficaram em 32\% (EEA, 2013). A reciclagem somada à compostagem nos países da União Europeia aumentou de 31\%, em 2004, para, 41\% em 2012, de acordo com o Relatório Bem Estar e Meio Ambiente (EEA, 2013). Entretanto, conforme apresentado na Figura 10 e na Figura 11, existem países com mais de 50\% de resíduos reciclados. Segundo as metas da União Europeia, em 2020, todos os países membros deverão reciclar pelo menos $50 \%$ dos resíduos sólidos urbanos gerados. Esta meta foi estabelecida em 2008 pela Diretiva de Resíduos (Waste Framework Directive). 
Figura 10 Taxa regional de reciclagem de resíduos sólidos urbanos em 2008/2009 na Europa

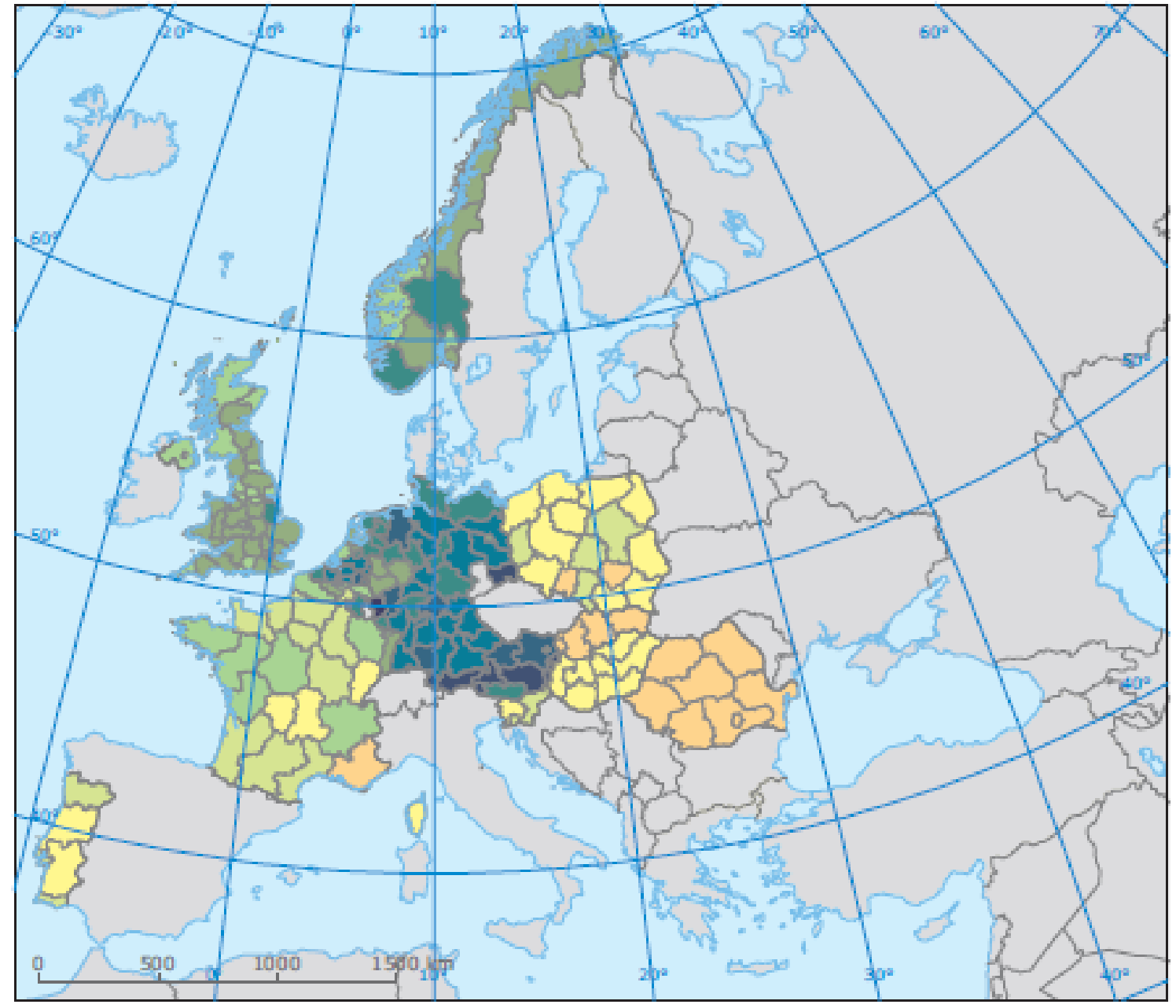

Reciclaaem municioal de resíduos. 2008/2009
$0-<10$ \%
$\square 30-<40$ \%
$40-<50 \%$
$10-<20 \%$
$50-<60 \%$

$60-<70 \%$
$70-<80 \%$
$80-<90 \%$

$90-100 \%$

Sem informação

Fonte: EEA, 2013

Nota: Reciclagem inclui material reciclado e compostagem/digestão. Taxas de reciclagem são calculadas como um percentual do resíduo sólido urbano gerado. Dados de 2008 usados para Bélgica, Alemanha, França, Hungria, Romênia e Eslovênia. Dados de 2009 foram usados para os demais países. 
Figura 11 Taxa de reciclagem de resíduos sólidos urbanos reciclados em 32 países europeus, em 2001 e 2010 (\%)

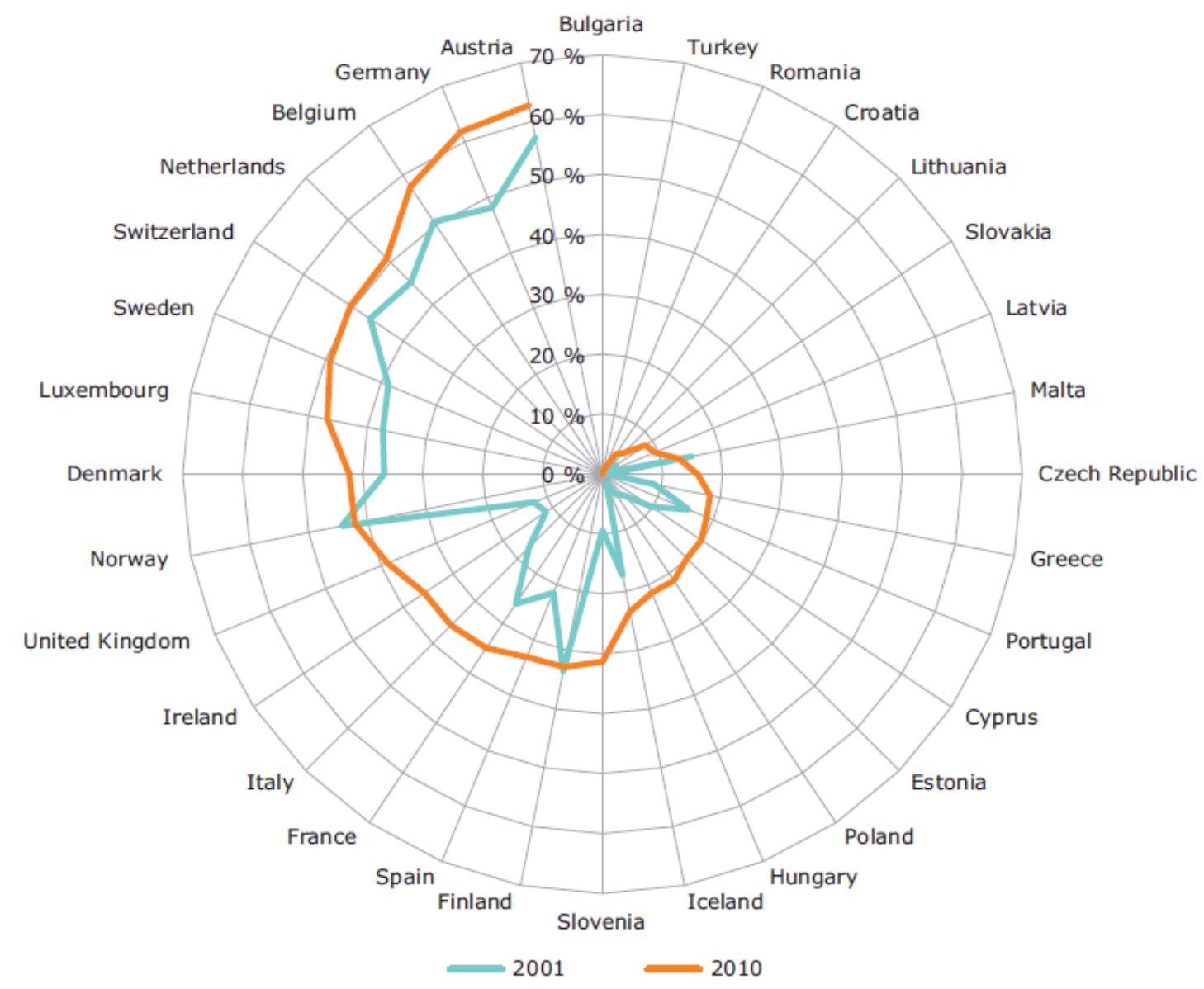

Fonte: EEA, 2013

Nota: quanto mais longe do centro no gráfico radar, melhor é a gestão de resíduos. A taxa de reciclagem é calculada como o percentual de resíduos sólidos urbanos produzidos que foi reciclado. Reciclagem total inclui a reciclagem de materiais, bem como a compostagem e digestão dos bio resíduos (orgânicos). De acordo com o Eurostat a comparabilidade dos dados ao longo do tempo é alta. No entanto, algumas interrupções na série temporal são documentadas, o que pode influenciar a comparabilidade entre países e dentro de um país. Em geral a qualidade dos dados melhorou durante o período de 2001-2010. Para a Islândia, os dados de 2008 foram utilizados os dados de 2010. Para a Eslovénia em 2002 foram usados dados de 2001 e 2009 foram usados os dados de 2010. A Croácia não está incluída em 2001. 


\section{Continente Africano}

Segundo dados da Divisão de Estatísticas das Nações Unidas (UNSTATS, 2011) dos 54 países existentes no continente africano, somente seis países reportaram informações sobre a existência de sistemas de reciclagem para Resíduos Sólidos Urbanos, conforme Tabela 4.

Tabela 4 Reciclagem de resíduos sólidos urbanos em países do continente africano, em 2011

\begin{tabular}{|c|c|c|c|c|c|c|}
\hline \multirow[b]{2}{*}{ País } & \multirow{2}{*}{$\begin{array}{c}\text { Último } \\
\text { Ano } \\
\text { Disponível }\end{array}$} & \multicolumn{5}{|c|}{ Resíduos Sólidos Urbanos } \\
\hline & & $\begin{array}{r}\text { Coletados } \\
(\times 1000 t)\end{array}$ & $\begin{array}{c}\text { Aterrados } \\
(\%)\end{array}$ & $\begin{array}{c}\text { Incinerados } \\
(\%)\end{array}$ & $\begin{array}{c}\text { Reciclados } \\
(\%)\end{array}$ & $\begin{array}{c}\text { Compostagem } \\
(\%)\end{array}$ \\
\hline Algéria & 2003 & $8.500,00$ & 99,90 & $\ldots$ & 0,10 & $\ldots$ \\
\hline Camarões & 2009 & $7.249,00$ & 99,60 & $\ldots$ & 0,40 & $\ldots$ \\
\hline Madagascar & 2007 & 419,00 & 96,70 & 0,00 & 0,00 & 3,50 \\
\hline $\begin{array}{l}\text { Ilhas } \\
\text { Mauricius }\end{array}$ & 2009 & 408,00 & 97,10 & $\ldots$ & 2,90 & $\ldots$ \\
\hline Marrocos & 2000 & $6.500,00$ & 98,00 & 0,00 & 2,00 & 0,00 \\
\hline Niger & 2005 & $9.750,00$ & 64,00 & 12,00 & 4,00 & $\ldots$ \\
\hline
\end{tabular}

Fonte: UNITAST, 2011

Nota: (...) Dado não disponível.

Segundo Liebenberg (2007), a coleta de recicláveis no continente africano, em geral, é desorganizada e informal, sendo praticada por pessoas pobres e desempregadas, que buscam nos recipientes de resíduos sólidos urbanos materiais para construção de abrigos, roupas e comida para melhorar sua condição de vida e, posterirormente, algum tipo de material que pode ser vendido para empresas de reciclagem. $O$ autor menciona que existem catadores nos aterros sanitários devido às grandes quantidades de materiais recicláveis que são descarregadas com os resíduos sólidos urbanos e aponta que a prática da catação nos aterros é uma situação de risco para a saúde e para a segurança pessoal dos catadores, além de gerar problemas operacionais nos aterros.

O Banco Africano de Desenvolvimento (THE AFRICA DEVELOPMENT BANK, 2002) apontou que na África do Sul cerca de 95\% dos resíduos sólidos 
gerados, incluindo aí os resíduos sólidos urbanos, são enviados para disposição no solo.

\section{África Do Sul}

A África do Sul passou pelo processo político do apartheid que restringiu o acesso aos serviços básicos de saneamento "de forma justa e equitativa" para os negros onde, até 1994, os "pobres sul-africanos não tinham acesso a serviços básicos como remoção de resíduos e água potável' (TISCHLER, 2013: 26).

Segundo Tischler, após o apartheid, a prioridade das políticas públicas foi ampliar os serviços de saneamento básico para todos os cidadãos e muitas políticas públicas e documentos de planejamento do governo sulafricano consideraram que a reciclagem dos resíduos sólidos era um importante elemento para a redução da geração dos resíduos, mesmo não tendo legislações em nível local que estabelecesse a obrigatoriedade dos munícipes fazerem a segregação dos resíduos na fonte geradora e encaminhá-los para processos de reciclagem.

A África do Sul gerou cerca de 59 milhões de toneladas de RSU em 2011, segundo o Departamento de Assuntos Ambientais (DEPARTMENT OF ENVIRONMENTAL AFFAIRS, 2012) sendo que foram estimados que 5,9 milhões de toneladas de resíduos foram reciclados $(\sim 10 \%)^{3}$ e 53,5 milhões de toneladas de resíduos gerais foram depositados em aterros. Segundo Tischler (2013), a África do Sul recicla cerca de $30 \%$ do total de resíduos sólidos gerados.

A composição dos resíduos gerais em 2011 para toda África do Sul está apresentada na Figura 12 onde pode-se verificar que os RSU (municipal solid waste) são bastante representativos em termos de massa, seguidos pelos

\footnotetext{
3 Neste total, estão inclusos resíduos gerais (domiciliar, limpeza urbana, estabelecimentos públicos), comerciais e industriais, excluindo resíduos perigosos.
} 
resíduos inertes provenientes da construção civil e pelos resíduos orgânicos e metais.

Figura 12 Composição dos resíduos sólidos urbanos na África do Sul, em 2011

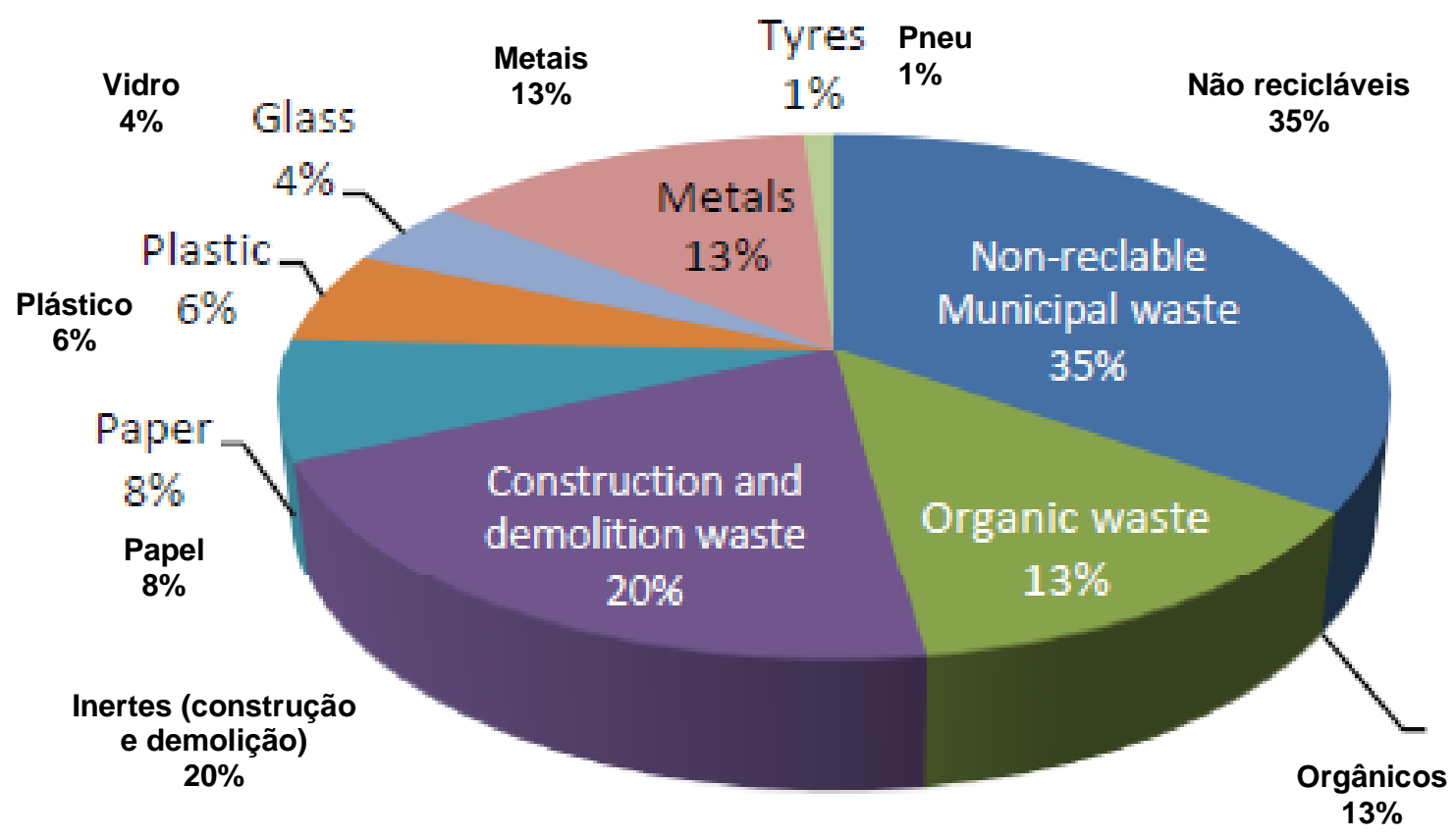

Fonte: Department of Environmental Affairs, 2012

\section{Brasil}

A geração de RSU no Brasil tem crescido, seguindo a tendência mundial. Segundo as informações do Diagnóstico do Manejo de Resíduos Sólidos Urbanos do Sistema Nacional de Informação em Saneamento (SNIS), a predominância da geração dos resíduos sólidos se concentra nas áreas urbanas, seguindo a tendência da concentração da população brasileira (BRASIL, 2016).

Cabe destacar que a cobertura da pesquisa nacional de saneamento não abrange todos os municípios brasileiros. Entretanto, em termos de representatividade para a população total urbana brasileira, a abrangência é significativa atualmente: dos municípios que responderam à pesquisa nacional, 
a participação da amostra em relação ao total da população urbana brasileira ultrapassou $80 \%$.

A Tabela 5 apresenta os dados do Diagnóstico do Manejo de Resíduos Sólidos Urbanos para o período de 2006 a 2016, dos resíduos sólidos totais coletados divididos em resíduos domiciliares, resíduos públicos (oriundos da varrição ou limpeza de logradouros públicos) e resíduos recolhidos pelas coletas seletivas. A coluna total de resíduos sólidos coletados não equivale à soma das coletas dos resíduos domiciliares e públicos pois existem outras quantidades de outros tipos de resíduos sólidos que não fazem parte deste trabalho.

Conforme Tabela 5, as quantidades de resíduos sólidos totais no Brasil aumentaram paulatinamente nos últimos 10 anos: entre 2006 e 2007, as quantidades totais permaneceram abaixo das 30 mil toneladas anuais sendo que a partir de 2011, ultrapassaram as 40 mil toneladas anuais, permanecendo crescentes, chegando a mais de 50 mil toneladas coletadas de resíduos sólidos em 2016 no Brasil, em amostra que representa mais de $80 \%$ da população urbana brasileira.

A evolução da coleta de resíduos sólidos domiciliares também foi crescente: em 2006, com 48,80\% de representatividade da amostra, foram coletados nos municípios pesquisados cerca de 13 mil toneladas e, a partir de 2010, as quantidades ultrapassaram as 20 mil toneladas. Os resíduos públicos (varrição e limpeza de espaços públicos) são menos representativos, mas também foram aumentando com o passar dos anos.

Especificamente as quantidades de resíduos provenientes da coleta seletiva, independente de quem coleta (contratadas, administrações municipais, cooperativas e outros), passaram de menos de $2 \%$ em relação ao total de resíduos domiciliares, entre 2006 e 2008, para cerca de 4\% logo após a publicação da Política Nacional de Resíduos Sólidos (2010), permanecendo 
neste patamar até 2012, quando houve um ligeiro decréscimo. Nos anos de 2014, 2015 e 2016, o percentual voltou a subir, atingindo cerca de 6\%.

Para o ano de 2009 na coleta seletiva (CS), observou-se que alguns municípios brasileiros apresentaram valores extremamente acima da média dos anos anteriores, inclusive valores muito superiores a grandes municípios como São Paulo. Foi solicitado ao Ministério das Cidades/por correio eletrônico a conferência destes valores, entretanto a resposta obtida foi que as responsabilidades dos dados são dos municípios.

Tabela 5 Quantidade de resíduos sólidos coletados no Brasil, de 2006 a 2016

\begin{tabular}{|c|c|c|c|c|c|c|}
\hline \multirow[b]{2}{*}{ Ano } & \multirow{2}{*}{$\begin{array}{l}\text { Participação } \\
\text { da Amostra } \\
\text { no Total da } \\
\text { População } \\
\text { Urbana (\%) }\end{array}$} & \multicolumn{5}{|c|}{ Resíduos Por Ano No Brasil (t) } \\
\hline & & Total (1) & Domiciliar (2) & Público (3) & Seletiva (4) & $\begin{array}{c}\% \\
\text { Seletiva/ } \\
\text { Domiciliar }\end{array}$ \\
\hline 2006 & 48,80 & 23.955.031,52 & $13.767 .522,09$ & $5.240 .310,78$ & $213.829,70$ & $1.55 \%$ \\
\hline 2007 & 54,80 & $29.629 .736,00$ & $16.417 .676,00$ & $7.262 .857,00$ & $311.296,70$ & $1.90 \%$ \\
\hline 2008 & 58,30 & $42.009 .039,04$ & $20.356 .042,65$ & $8.326 .123,15$ & $322.301,95$ & $1.58 \%$ \\
\hline $\begin{array}{l}2009 \\
(5)\end{array}$ & 68,60 & $32.934 .435,14$ & $19.509 .106,58$ & $5.986 .678,58$ & $3.097 .294,93$ & $15.88 \%$ \\
\hline 2010 & 72,80 & $37.671 .050,09$ & 22.603.372,07 & $5.301 .887,84$ & $995.004,10$ & $4.40 \%$ \\
\hline 2011 & 73,30 & $42.482 .254,60$ & $22.582 .657,80$ & $5.433 .356,00$ & $985.825,30$ & $4.37 \%$ \\
\hline 2012 & 81,10 & $49.533 .702,60$ & $24.495 .621,20$ & $7.123 .696,10$ & $966.750,60$ & $3.95 \%$ \\
\hline 2013 & 84,31 & $54.225 .652,50$ & 25.874.677.30 & $8.650 .554,10$ & $982.765,00$ & $3.80 \%$ \\
\hline 2014 & 86,10 & $57.945 .369,30$ & 26.893.262.10 & $9.917 .965,60$ & $1.455 .138,80$ & $5.41 \%$ \\
\hline 2015 & 82,80 & $53.620 .816,60$ & 26.099 .886 .90 & $7.918 .837,60$ & $1.954 .867,50$ & $7.49 \%$ \\
\hline 2016 & $\cdots$ & $51.620 .816,60$ & 25.142.299.20 & $3.012 .059,40$ & $1.562 .696,40$ & $6.22 \%$ \\
\hline TOTAL & - & 475.627.903,99 & 243.742.123,89 & 74.174.326,15 & $12.847 .770,98$ & $5.27 \%$ \\
\hline MÉDIA & - & $43.238 .900,36$ & 22.158.374,90 & 6.743 .120 .56 & 1.167.979,18 & \\
\hline
\end{tabular}

Fonte: BRASIL, 2016

Nota: (...): dado não disponível. (1) Valor anual da soma das quantidades totais de resíduo domiciliar (RDO) e resíduo público (RPU) coletadas por todos os agentes mencionados, públicos, privados e outros agentes, exceto cooperativas de catadores. (2) Quantidade anual de resíduo domiciliar (RDO) coletada por todos os agentes executores público, privado ou outro(s) agente(s) executor(es), exceto cooperativas ou associações de catadores. Não inclui quantidade de resíduo público (RPU) coletada. (3) resíduos públicos (RPU): oriundo da varrição ou limpeza de logradouros públicos. Quantidade anual de resíduo público (RPU) coletado por serviço executado diretamente pelos agentes públicos. Não inclui quantidade de resíduo domiciliar (RDO) coletado. Considera-se como agente público a Prefeitura (qualquer órgão de 
sua administração direta centralizada -secretaria, departamento, divisão ou seção) ou administração descentralizada (empresa pública ou autarquia). (4) Valor anual do resultado da soma das quantidades de resíduos sólidos recolhidos, por meio do serviço de coleta seletiva por todos os agentes - público, privado, associações de catadores e outros que detenham parceria com a Prefeitura. Excluem-se quantidades de matéria orgânica quando coletadas de forma exclusiva. (5) Particularmente para o ano 2009, constatou-se que alguns municípios preencheram as quantidades de resíduos da coleta seletiva, provavelmente, com equívoco nas unidades de massa: o município de Sede Nova/RS declarou que em 2009 coletou seletivamente 191.890 toneladas de resíduos da coleta seletiva sendo que no ano seguinte, declarou que coletou 150 toneladas; o município de União da Vitória/PR declarou que coletou seletivamente em 2009, 73.440 toneladas entretanto em 2010, declarou que foram coletadas seletivamente 59 toneladas de resíduos; Santopólis do Aguapeí/SP declarou que em 2009, coletou seletivamente 10.000 toneladas de resíduos entretanto em 2010, declarou que não possuía evidencia de coleta seletiva. Assim, a discrepância para o percentual de coleta seletiva em relação ao total de resíduos sólidos domiciliares para o ano de 2009 para o Brasil (15.88\%), deve ser utilizado com parcimônia.

A Tabela 6 apresenta as quantidades de resíduos sólidos recolhidos por diversas coletas seletivas no Brasil, de 2006 a 2016, segundo SNIS, por tipo de executores: (i) diretamente pelas administrações municipais; (ii) empresas contratadas pelas administrações municipais; e (iii) catadores com apoio de prefeituras.

Tabela 6 Quantidade de resíduos sólidos recolhidos por coletas seletivas, Brasil, de 2006 a 2016

\begin{tabular}{|c|c|c|c|c|c|c|}
\hline \multirow[b]{2}{*}{ Ano } & \multirow{2}{*}{$\begin{array}{c}\text { Participação } \\
\text { da Amostra } \\
\text { no Total da } \\
\text { População } \\
\text { Urbana (\%) }\end{array}$} & \multicolumn{5}{|c|}{$\begin{array}{c}\text { Quantidade De Resíduos Sólidos De Coletas Seletivas Recolhidos } \\
\text { Por Agentes Brasil (t) }\end{array}$} \\
\hline & & Seletiva (1) & $\begin{array}{l}\text { Prefeitura ou } \\
\text { SLU (2) }\end{array}$ & $\begin{array}{c}\text { Empresas } \\
\text { Contratadas } \\
\text { (3) }\end{array}$ & $\begin{array}{c}\text { Catadores } \\
\text { com Apoio } \\
\text { das } \\
\text { Prefeituras } \\
\text { (4) }\end{array}$ & Outros (5) \\
\hline 2006 & 48,80 & $213.829,70$ & $56.357,10$ & $65.868,00$ & $69.025,70$ & $22,060.00$ \\
\hline 2007 & 54,80 & $311.296,70$ & $72.861,10$ & $80.101,40$ & $157.062,50$ & 230.40 \\
\hline 2008 & 58,30 & $322.301,95$ & $64.072,15$ & $121.004,08$ & $107.654,69$ & $10,572.73$ \\
\hline 2009 & 68,60 & $3.097 .294,93$ & 2.708.191,95 & $1.283 .702,98$ & $1.581 .177,91$ & $18,436.00$ \\
\hline 2010 & 72,80 & $995.004,10$ & $538.260,10$ & 1.101 .333 .20 & $373.063,60$ & $21,234.40$ \\
\hline 2011 & 73,30 & $985.825,30$ & $299.111,60$ & $443.594,10$ & $523.571,90$ & $2,026.00$ \\
\hline 2012 & 81,10 & $966.750,60$ & $349.275,40$ & $462.480,10$ & $434.072,60$ & $13,317.60$ \\
\hline 2013 & 84,31 & $982.765,00$ & $207.252,00$ & $448.367,00$ & $327.147,00$ & $5,776.10$ \\
\hline 2014 & 86,10 & $1.455 .138,80$ & $274.635,00$ & $571.438,60$ & $729.062,40$ & $7,714.60$ \\
\hline 2015 & 82,80 & $1.954 .867,50$ & $469.700,30$ & $862.559,50$ & $908.868,10$ & $13.739,60$ \\
\hline 2016 & $\ldots$ & $1.562,696,40$ & $279.677,20$ & $763.142,80$ & $497.700,00$ & $22.176,40$ \\
\hline TOTAL & & $12,847.770,98$ & $5.319 .393,90$ & $6.203 .591,76$ & $5.708 .406,40$ & $137.283,83$ \\
\hline
\end{tabular}


Fonte: BRASIL, 2016

Nota: (...) Dado não disponível. (1) Valor anual do resultado da soma das quantidades de resíduos sólidos recolhidos, por meio do serviço de coleta seletiva por todos os agentes público, privado, associações de catadores e outros que detenham parceria com a Prefeitura. Excluem-se quantidades de matéria orgânica quando coletadas de forma exclusiva. (2) Quantidade anual de resíduos sólidos domiciliares recolhidos diretamente pelo agente público (prefeitura, empresa pública ou autarquias) por meio do serviço de coleta seletiva. Excluem-se as quantidades de matéria orgânica quando coletadas de forma exclusiva. '(3) Quantidade anual de resíduos sólidos domiciliares recolhidos pelos agentes privados contratados pela Prefeitura ou SLU por meio do serviço de coleta seletiva. Excluem-se as quantidades de matéria orgânica quando coletadas de forma exclusiva. (4) Quantidade anual de resíduos sólidos domiciliar recolhidos pelas organizações de catadores (associações ou cooperativas) que contam com parceria ou apoio técnico-operacional do agente público, por meio do serviço de coleta seletiva. Excluem-se quantidades de matéria orgânica quando coletadas de forma exclusiva. (5) Quantidade anual de resíduos recolhida por outros agentes executores da coleta seletiva que detenham alguma 'parceria' com a Prefeitura. Enquadram-se neste caso, as quantidades recolhidas por entidades filantrópicas que tenham parceria ou apoio técnicooperacional da Prefeitura e que destinam o produto de sua coleta para a Prefeitura. Excluem-se quantidades de matéria orgânica quando coletadas de forma exclusiva.

Para os anos de 2006 a 2008, os resíduos coletados seletivamente estavam sendo recolhidos, predominantemente pelas administrações municipais. A partir de 2010, registra-se uma alteração: a coleta seletiva passa a ser realizada, predominantemente, por empresas privadas contratadas pelas administrações municipais e por organização de catadores com apoio das prefeituras municipais. Pode-se associar o aumento da presença das cooperativas e associações de catadores com apoio de prefeituras atuando na coleta seletiva em função da Política Nacional de Resíduos Sólidos. Registrase, mesmo que incipiente, a importância das políticas públicas que incentivam a coleta seletiva e, consequentemente, a reciclagem de materiais secos. Cabe mencionar, conforme já apresentado que as quantidades recolhidas pela coleta seletiva em 2009, são incoerentes em relação aos anos, podendo ter ocorrido erro de preenchimento do questionário por parte de alguns municípios. 


\section{MÉTODOS}

Os métodos utilizados nesta pesquisa estão apresentados a seguir.

\subsection{ESTUDO DE CASO}

O método definido para investigar comparativamente as políticas públicas que elevam as taxas de coleta de resíduos sólidos urbanos com segregação na fonte geradora (coleta seletiva) em três municípios foi o estudo de caso, retratando múltiplos casos.

O estudo de caso, conforme apontado por Yin (2005: 32), permite a investigação de um "fenômeno contemporâneo dentro do seu contexto da vida real" e ainda:

- Baseia-se em várias fontes de pesquisa;

- Pode explicar vínculos causais em situações da vida real que são muito complexas para serem explicados por estudos experimentais;

- Permite identificar programas bem sucedidos;

- Pode ser utilizado para explorar situações nas quais a intervenção que está sendo avaliada não apresenta um conjunto simples e claro de resultados.

\subsection{DEFINIÇÃO DAS ÁREAS DE ESTUDO}

Esta pesquisa focou na seleção de unidades territoriais urbanas haja vista que, predominantemente, no mundo, a responsabilidade pela manutenção da limpeza urbana, gerenciamento e gestão de resíduos sólidos urbanos é responsabilidade do poder público local.

A seleção dos três municípios estudados baseou-se nos seguintes critérios:

- Identificar um município que fosse referência mundial no reaproveitamento e reciclagem de resíduos sólidos urbanos, com 
processos tecnológicos que não incluíssem incineração e de fácil replicação, com adaptações à realidade brasileira, e que estivesse com seu sistema de gerenciamento de resíduos maduro. Priorizou-se, municípios com ações de políticas públicas que praticam o conceito de "resíduo zero", ou seja, a minimização de resíduos sólidos e o envio de quantidades mínimas de rejeitos para aterros sanitários;

- Selecionar município do grupo de países do BRICS ${ }^{4}$, com semelhanças econômicas, sociais e políticas ao Brasil e que possuísse sistema de gerenciamento de resíduos sólidos com informações técnicas acessíveis, com coleta de materiais recicláveis com participação da população local, por meio de associações e/ou ONGs que promovessem a inserção de população de catadores que atuam na coleta seletiva de resíduos sólidos urbanos, predominantemente domiciliares;

- Eleger um município brasileiro, com maiores quantidades de geração de resíduos sólidos urbanos, com sistema de coleta seletiva de resíduos domiciliares implantados com participação do setor formal (empresas concessionarias) e informal (associações e cooperativas de catadores) e que necessita de ajustes técnicos, operacionais, de participação popular para a separação dos resíduos na fonte geradora, cujas políticas públicas implantadas ainda não refletem os preceitos da Política Nacional de Resíduos Sólidos.

Com base nos critérios de seleção dos municípios, foi realizada pesquisa nas bases de dados da rede mundial de computadores (www) de artigos

\footnotetext{
${ }^{4}$ O termo BRIC (Brasil, Rússia, Índia, China) foi utilizado a primeira vez por Jim O'Neill (O'NEILL, 2001), economista do banco Goldman Sachs para identificar os países emergentes que não faziam parte do G7, mas que tinham importância econômica, social e política mundial, as chamadas econômicas emergentes. Segundo o Ministério das Relações Exteriores, a primeira reunião "iniciou-se de maneira informal em 2006, com reunião de trabalho à margem da abertura da Assembleia Geral das Nações Unidas" (BRASIL, 2017) e posteriormente, o grupo dos quatro países passou a formar uma entidade político-diplomática permanente que se reúne anualmente para discutir diversos assuntos de interesses mútuos para estimular cooperações entre os integrantes. Em 2011, a África do Sul foi inserida na entidade e a sigla da entidade passou a ser denominada como BRICS. Segundo FERNANDES (2015), em 2011, o grupo de países do BRICS detinha $28 \%$ do PIB mundial e concentrava $42 \%$ da população mundial e o maior poder de consumo do mundo.
} 
científicos em bases bibliográficas, bem como em sites de instituições de pesquisa reconhecidamente especializadas no tema gerenciamento de resíduos sólidos, de forma a selecionar as cidades mais adequadas para a pesquisa.

As palavras chave foram pesquisadas, em junho de 2015, em inglês e português, sendo: recycling, municipality solid waste, recycling household, public policies increase recycling, coleta seletiva de resíduos domiciliares, políticas públicas de resíduos sólidos urbanos. As palavras chaves foram utilizadas também para o levantamento bibliográfico.

Ao longo de todo período de pesquisa, manteve-se a verificação nos endereços eletrônicos pesquisados com as mesmas palavras chave e aviso automático da disponibilização de novos artigos associados ao objeto de pesquisa, a fim de atualizar a busca.

A fim de definir os municípios a serem estudados, foi realizado um levantamento preliminar para os maiores em termos de importância política, econômica, populacional e geração de RSU nos países dos BRICS. Os municípios pré-selecionados estão apresentadas no Quadro 8 a seguir.

Quadro 8 Municípios pré-selecionados para definição da área de estudo

\begin{tabular}{|l|l|r|}
\hline $\begin{array}{l}\text { Países } \\
\text { BRICS }\end{array}$ & \multicolumn{1}{|c|}{ Município } & \multicolumn{1}{|c|}{ População } \\
\hline \multirow{4}{*}{ Brasil } & São Paulo (1) & $12.106 .920(2017)$ \\
\cline { 2 - 3 } & Rio de Janeiro (1) & $6.520 .266(2017)$ \\
\cline { 2 - 3 } & Belo Horizonte (1) & $2.523 .794(2017)$ \\
\hline \multirow{2}{*}{ Rússia } & Moscou (2) & $12.170 .000(2015)$ \\
\cline { 2 - 3 } & São Petersburgo (3) & $4.993 .000(2017)$ \\
\hline \multirow{4}{*}{ China (1) } & Xangai (2) & $23.740 .000(2015)$ \\
\cline { 2 - 3 } & Pequim (2) & $20.380 .000(2015)$ \\
\cline { 2 - 3 } & Guangzhou (2) & $12.460 .000(2015)$ \\
\hline \multirow{3}{*}{ Índia } & Mumbai (2) & $21.400 .000(2015)$ \\
\cline { 2 - 3 } & Calcutá (2) & $14.864 .919(2015)$ \\
\cline { 2 - 3 } & Bangalore (2) & $10.900 .000(2015)$ \\
\hline \multirow{2}{*}{ frica do Sul } & Johanesburgo (4) & $4.434 .827(2011)$ \\
\cline { 2 - 3 } & Cidade do Cabo (4) & $3.740 .026(2011)$ \\
\hline
\end{tabular}


Fonte: (1) https://cidades.ibge.gov.br/brasil/sp/sao-paulo/panorama; (2) https://esa.un.org/unpd/wup/CD-ROM/; (3) https://www.cia.gov/library/publications/the-world-factbook/fields/2219.html; http://www.statssa.gov.za/?page_id=1021\&id=city-of-cape-town-municipality

Após a definição dos municípios foi realizado novo levantamento de dados bibliográficos disponíveis na rede mundial de computadores, cujos critérios de seleção foram: (i) publicação de pesquisas para os municípios do BRICS para o tipo de resíduos sólidos urbanos pesquisado; (ii) viabilidade de execução de pesquisa de campo, tanto em termos de logística como de possíveis contatos com representantes dos municípios que pudessem receber a pesquisadora; (iii) avaliação da existência de pesquisadores e/ou departamentos de setores de limpeza urbana que poderiam apoiar a pesquisadora na obtenção de dados quantitativos e qualitativos para alcançar os objetivos da pesquisa.

Para os países e respectivos municípios selecionados (Quadro 8), não foram identificados artigos disponíveis para a Rússia. Para a Índia, foram encontrados muitos artigos associados à coleta seletiva com o setor informal (catadores) e de outros tipos de resíduos que não são objeto da pesquisa em tela. Para a África do Sul, foram encontrados artigos sobre a coleta seletiva na Cidade do Cabo e em Johanesburgo. A matriz de elegibilidade das cidades estudadas está apresentada no Quadro 9.

Quadro 9 Matriz de Elegibilidade de municípios a serem estudadas nos BRICS

\begin{tabular}{|c|c|c|c|c|c|}
\hline \multirow[b]{2}{*}{$\begin{array}{l}\text { Países } \\
\text { BRICS }\end{array}$} & \multirow[b]{2}{*}{ Municípios } & \multicolumn{3}{|c|}{ Critérios de Seleção } & \multirow[b]{2}{*}{ Resultado } \\
\hline & & $\begin{array}{c}\text { Artigos } \\
\text { Disponíveis }\end{array}$ & $\begin{array}{c}\text { Facilidade } \\
\text { de } \\
\text { Pesquisa } \\
\text { de Campo }\end{array}$ & $\begin{array}{l}\text { Conhecimento } \\
\text { ou Contato Pré } \\
\text { Existente dos } \\
\text { Pesquisadores? }\end{array}$ & \\
\hline \multirow{3}{*}{ Brasil } & São Paulo & $\operatorname{sim}$ & $\operatorname{sim}$ & $\operatorname{sim}$ & elegível \\
\hline & Rio de Janeiro & $\operatorname{sim}$ & $\operatorname{sim}$ & $\operatorname{sim}$ & elegível \\
\hline & Belo Horizonte & $\operatorname{sim}$ & $\operatorname{sim}$ & $\operatorname{sim}$ & elegível \\
\hline \multirow[b]{2}{*}{ Rússia } & Moscou & não & não & não & descartado \\
\hline & $\begin{array}{l}\text { São } \\
\text { Petersburgo }\end{array}$ & não & não & não & descartado \\
\hline \multirow{2}{*}{ China } & Xangai & $\operatorname{sim}$ & não & não & descartado \\
\hline & Pequim & $\operatorname{sim}$ & não & não & descartado \\
\hline
\end{tabular}




\begin{tabular}{|c|c|c|c|c|c|}
\hline \multirow[b]{2}{*}{$\begin{array}{l}\text { Países } \\
\text { BRICS }\end{array}$} & \multirow[b]{2}{*}{ Municípios } & \multicolumn{3}{|c|}{ Critérios de Seleção } & \multirow[b]{2}{*}{ Resultado } \\
\hline & & $\begin{array}{c}\text { Artigos } \\
\text { Disponíveis }\end{array}$ & $\begin{array}{c}\text { Facilidade } \\
\text { de } \\
\text { Pesquisa } \\
\text { de Campo }\end{array}$ & $\begin{array}{c}\text { Conhecimento } \\
\text { ou Contato Pré } \\
\text { Existente dos } \\
\text { Pesquisadores? }\end{array}$ & \\
\hline & Guangzhou & $\operatorname{sim}$ & não & não & descartado \\
\hline \multirow{3}{*}{ Índia } & Mumbai & $\operatorname{sim}$ & não & não & descartado \\
\hline & Calcutá & $\operatorname{sim}$ & não & não & descartado \\
\hline & Bangalore & $\operatorname{sim}$ & não & não & descartado \\
\hline \multirow{2}{*}{$\begin{array}{l}\text { África } \\
\text { do Sul }\end{array}$} & Johanesburgo & $\operatorname{sim}$ & $\operatorname{sim}$ & $\operatorname{sim}$ & elegível \\
\hline & Cidade do Cabo & $\operatorname{sim}$ & $\operatorname{sim}$ & $\operatorname{sim}$ & elegível \\
\hline
\end{tabular}

Conforme Quadro 9, os municípios da Rússia, China e Índia foram descartados considerando as dificuldades para realização da pesquisa de campo e pela inexistência de contatos para obter dados quantitativos e qualitativos. Sendo assim, o foco passou a ser a seleção do município brasileiro e sul-africano.

A seleção final dos municípios para pesquisa foi qualitativa, sendo:

- Brasil: o município de Belo Horizonte foi descartado pois já foi estudado no estudo comparativo das Nações Unidas (UN, 2010). O município do Rio de Janeiro foi descartado pois no levantamento de artigos acadêmicos sobre coleta seletiva de resíduos sólidos urbanos estavam disponíveis 8 artigos, dos quais nenhum associado ao objeto de pesquisa. Para o município de São Paulo, na nova pesquisa sobre a coleta seletiva de resíduos sólidos urbanos foram encontrados 75 artigos, dos quais 4 estavam associadas ao tema de pesquisa. Com base nestas análises e na facilidade de obtenção de dados, o município de São Paulo foi selecionado;

- Na África do Sul, foi selecionada a Cidade do Cabo, por contatos prévios já existentes com a orientadora desta tese, por referências positivas encontradas na literatura e pelo envolvimento de cooperativas/associações de catadores na coleta seletiva; 
- No caso da cidade em nível mundial, que é referência na coleta e na reciclagem dos resíduos sólidos urbanos sem processos de incineração, com políticas públicas com conceito Resíduo Zero, o município identificado foi São Francisco, nos Estados Unidos.

Ao final, os três municípios selecionados foram: São Francisco, Cidade do Cabo e São Paulo. A localização dos municípios selecionados está apresentada na Figura 13.

Figura 13 Localização dos municípios estudados

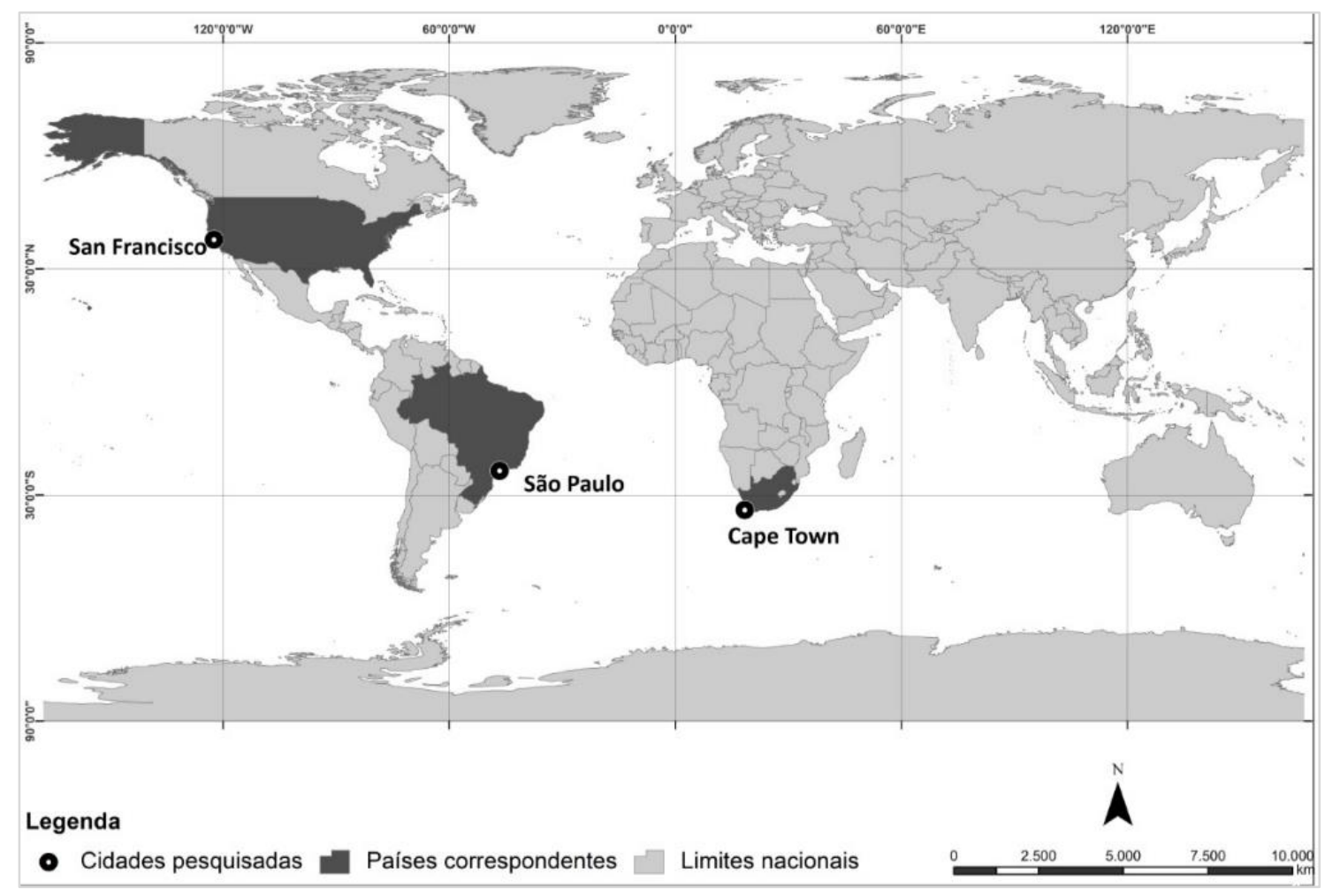

Elaboração: a autora

\subsection{PERÍODO DE ESTUDO}

O período do estudo de casos foi definido para uma década, entre 2006 a 2016, pois as implantações de políticas públicas e seus reflexos nas taxas de RSU, muitas vezes, não são identificadas rapidamente em função de necessitarem de um período mínimo de maturação para serem 
operacionalizadas: desde a criação da política, até sua execução e implantação de instrumentos de monitoramento para avaliar sua eficiência.

\subsection{PESQUISA BIBLIOGRÁFICA}

A pesquisa bibliográfica foi realizada a partir de leitura e análise da literatura especializada disponível em artigos científicos, por meio de busca em bases bibliográficas (Scielo, Pubmed, Web of science) por palavra chave em inglês: recycling, municipality solid waste, recycling household, public policies increase recycling. Em português, as palavras chaves pesquisadas foram: coleta seletiva de resíduos domiciliares, políticas públicas de resíduos sólidos urbanos.

Foi realizado um primeiro levantamento de artigos disponíveis em língua inglesa associados às palavras chaves, em junho de 2015. Os resultados preliminares da busca bibliográfica apontaram 392 artigos internacionais que continham em seu título as palavras chaves definidas. A partir desta listagem foi feita uma análise do título e resumo de cada artigo e foram selecionados aqueles que apontavam que 0 artigo se referia ao reaproveitamento e/ou reciclagem dos RSU nos países e municípios selecionados, ou aqueles que poderiam ser utilizados como referenciais teóricos.

Desta triagem, foram identificados 74 artigos em inglês que, durante o desenvolvimento desta pesquisa, foram analisados e serviram de referências para esta tese. A busca pelas palavras chave em português, resultou em 122 artigos, dos quais 15 foram analisados e 7 utilizados como referências.

Também foram realizadas buscas direcionadas a estudos, relatórios e outros documentos técnicos associados à reutilização e reciclagem de resíduos sólidos urbanos nos endereços eletrônicos das seguintes instituições internacionais: Organização das Nações Unidas, Banco Mundial, Comissão Ambiental da União Europeia, Internacional Solid Waste Association (ISWA), 
Environemntal Protection Agency (USEPA), órgãos públicos ambientais dos países estudados (Estados Unidos, África do Sul e Brasil).

Para os municípios do estudo de caso foram consultados os endereços eletrônicos da rede mundial de computadores (www).

Complementarmente, foram realizadas pesquisas sobre a existência de instrumentos legais que materializam as políticas públicas para reutilização e reciclagem nos três municípios estudados.

Especificamente para o município de São Paulo, durante a pesquisa bibliográfica, identificou-se que as informações sobre as quantidades de resíduos sólidos urbanos triados e enviados para processos de reutilização e/ou reciclagem eram divergentes no documento Plano de Gerenciamento Integrado de Resíduos Sólidos (SÃO PAULO, 2014), em vigor. Nos municípios de São Francisco e Cidade do Cabo, não foram encontradas estas incoerências.

Então, optou-se, no caso de São Paulo, aprofundar a coleta de dados de quantidades de resíduos sólidos urbanos que são encaminhados para processos de triagem e, consequentemente, para reutilização e reciclagem. A Autoridade Municipal de Limpeza Urbana (AMLURB) do município de São Paulo registra, diariamente, as quantidades de resíduos sólidos coletadas por cada caminhão envolvido na coleta convencional ou coleta seletiva, por meio do sistema de pesagem dos caminhões em balanças eletrônicas e transmissão eletronicamente, em tempo real, para a central da AMLURB, os quais são armazenados no Sistema de Controle de Resíduos Sólidos Urbanos (SISCOR).

O SISCOR tem como objetivo: (i) controlar as pesagens dos serviços de limpeza urbana, (ii) efetuar as medições dos serviços para posterior pagamento dos contratos e (iii) controlar o pagamento do entulho recolhido pelas empresas particulares (caçambas) (PRODAM, 2017).

Os tipos de resíduos sólidos urbanos contabilizados pelo SISCOR originados nos serviços de limpeza urbana são divisíveis, indivisíveis essenciais e complementares e envolve: alimentos vencidos, animais, chorume, diversos, 
escória, esgoto, domiciliar, entulho manual, entulho mecanizado, feira livre, pequenos geradores de saúde, grandes geradores de saúde, rejeitos, transbordo, poda, remoção resíduos descartados, resíduos de boca de lobo, resíduos de córregos, resíduos de Ecopontos, resíduos de piscinão, resíduos gerados nas unidades da SABESP, da coleta seletiva domiciliar e das atividades de varrição de logradouros.

Foram selecionados os resíduos sólidos domiciliares que representaram $68 \%$ do total, em 2016, e que alimentam a coleta seletiva, considerando-se que, em São Paulo, são os resíduos domiciliares os recolhidos, triados e encaminhados para processos de reciclagem e que entraram nas estatísticas para cálculo do percentual de reciclagem do município. Os dados obtidos do SISCOR são expressos em quilogramas e foram transformados em toneladas, permitindo agrupamentos por Prefeituras Regionais (31 unidades). Não foi possível agrupar os dados por Distritos Municipais (96 distritos), criados pela lei municipal no 11.220/92, pois os limites geográficos dos setores de coleta de cada caminhão são incompatíveis com os limites dos Distritos.

Foram obtidos dados mensais para os 10 anos, de 2006 a 2016, compondo um universo de 120 planilhas que continham todos os resíduos sólidos urbanos coletados. Para cada mês foi realizada uma seleção de dados onde se buscou separar os dados de resíduos sólidos domiciliares e da coleta seletiva por Prefeitura Regional. Posteriormente foram elaboradas 10 planilhas que continham o resumo de cada ano do período estudado. Estas planilhas foram agrupadas em uma única, que apresenta a relação do total de resíduos sólidos urbanos, dos resíduos domiciliares e da coleta seletiva, a fim de calcular a taxa de resíduos sólidos que foram encaminhados para algum processo de reciclagem.

Estes dados estão apresentados no capítulo Resultados, no item correspondente ao município de São Paulo. 


\subsection{SELEÇÃO DE VARIÁVEIS PARA O ESTUDO DE CASO}

A seleção de variáveis para caracterização dos sistemas de resíduos sólidos urbanos e as políticas públicas que influenciam diretamente as taxas de reciclagem de resíduos dos municípios estudados foi baseada no estudo internacional realizado pelas Nações Unidas para o Terceiro Relatório de Saneamento e Água em Cidades Mundiais: Solid Waste Management in the World's Cities. Water and Sanitarion in the World's Cities 2010. O foco do Relatório esteve baseado em:

- Pesquisar as boas práticas que vem sendo executadas para gerenciamento de sistemas de resíduos sólidos em municípios pequenos e grandes, ricos e pobres, ao redor do mundo;

- Investigar os fatores que impulsionam as mudanças no gerenciamento de resíduos sólidos, o que funciona em cada cidade e o que pode funcionar melhor e sob que circunstâncias;

- Apoiar representantes de poderes públicos e privados, assim como os cidadãos, a implantarem sistemas de gerenciamento de resíduos sólidos adequados;

- Promover a referência para boas práticas por meio do compartilhamento de experiências bem sucedidas, de forma que os sistemas de resíduos sólidos estejam adequadas para cada município.

Posteriormente foram definidas as variáveis específicas para este estudo que estão apresentadas no item 5.7.

\subsection{LEVANTAMENTOS DE CAMPO}

A partir das pesquisas bibliográficas, foi possível identificar as instituições responsáveis pelo gerenciamento dos resíduos sólidos urbanos nos municípios estudados e iniciar contatos por meio de correio eletrônico para São Francisco e Cidade do Cabo e contatos telefônicos para São Paulo, visando agendar visitas técnicas e entrevistas. 
Os contatos foram iniciados em janeiro de 2017 e os levantamentos de campo foram planejados para o primeiro semestre de 2017.

Cabe destacar que a pesquisadora efetuou visita técnica ao Departamento de Meio Ambiente de São Francisco em julho de 2014 e já havia recebido informações técnicas. Posteriormente foram realizados novos contatos com Departamento de Meio Ambiente para um novo levantamento de campo em 2017, entretanto não houve retorno dos responsáveis para autorizar esta atividade. Neste caso, as informações atualizadas foram obtidas por correio eletrônico.

$\mathrm{Na}$ Cidade do Cabo, o levantamento em campo ocorreu em fevereiro e março de 2018, a partir de contatos iniciais realizados em 2013 por Ribeiro (2013).

Em São Paulo, foi possível seguir o cronograma inicial: foram realizadas oito visitas e entrevistas na AMLURB e unidades de triagem de resíduos sólidos. As datas dos levantamentos de campo estão apresentadas no Apêndice 2.

O levantamento de campo realizado consistiu de: (i) vistas técnicas em unidades de tratamento, triagem e disposição final de resíduos sólidos; (ii) entrevistas com responsáveis pelas coletas de resíduos sólidos urbanos com separação na fonte (ou coleta seletiva) dos municípios estudados.

O foco das visitas técnicas foi entender como se dão os processos de cada unidade e estabelecer vínculos com os responsáveis, a fim de obter informações qualitativas, muitas vezes não disponíveis em documentos técnicos.

As entrevistas foram realizadas a partir de um roteiro semi estruturado, cujo objetivo foi obter informações similares em cada um dos municípios do estudo. O roteiro das entrevistas encontra-se apresentado no Apêndice 3.

Cabe destacar algumas especificidades encontradas durante os levantamentos de campo. São elas: 
- A obtenção de dados quantitativos para as taxas de reciclagem de resíduos urbanos secos foi sempre difícil. Somam-se também, alterações na forma de apresentação de dados para o período de 10 anos estudados, exigindo grande esforço para analisar os dados, quando obtidos;

- A gravação das entrevistas foi realizada, sempre que o representante da instituição permitiu, e foram arquivadas para servirem de ajuda memória para tópicos discutidos durante a entrevista, que eventualmente, não estivessem contidos no roteiro de entrevista;

- Tanto em São Paulo quanto na Cidade do Cabo, a tarefa de obter respostas para o roteiro de entrevista foi árdua pois, geralmente, os setores ou departamentos que gerenciam os resíduos sólidos urbanos possuem muitas compartimentações e, às vezes, a resposta a uma simples pergunta significa identificar o responsável e verificar a sua disponibilidade para as respostas. Este fato gerou 18 visitas às instituições e um tempo longo para o levantamento de campo. As datas dos levantamentos de campo realizados estão apresentadas no Apêndice 4.

\subsection{COMPARAÇÃO E AVALIAÇÃO DOS ESTUDOS DE CASO}

Para comparar os três municípios estudados foram identificadas variáveis relacionadas aos objetivos da pesquisa e definidas variáveis baseadas no referencial teórico apresentado no Capítulo 4.

Posteriormente, foi criado um critério de hierarquização com notas máxima, mínima e média para todas as dez variáveis, cuja função foi identificar maior ou menor proximidade a bons sistemas de gerenciamento de resíduos sólidos. Foi dado destaque para a segregação dos resíduos na fonte geradora e na coleta, sendo cinco variáveis para caracterização e avaliação dos sistemas 
de coleta e cinco para avaliar as políticas públicas e instrumentos de gestão existentes.

As notas receberam valores numéricos, para facilitar a identificação, por variável, sendo:

- Nota máxima: valor numérico 3;

- Nota média: valor numérico 2;

- Nota mínima: valor numérico 1.

Para a caracterização das coletas de resíduos sólidos com segregação na fonte geradora para os três municípios estudados foram selecionadas as seguintes variáveis:

- Abrangência: a coleta de resíduos sólidos urbanos é um elemento fundamental para a saúde pública de um município. Quanto maior o acesso da população à coleta de resíduos, menores são as chances de doenças transmissíveis;

- Frequência: a frequência e a regularidade são fatores de manutenção da segregação na fonte;

- Eficiência: quanto mais eficiente a coleta com separação na fonte dos resíduos, maiores são as quantidades coletadas e encaminhadas para reaproveitamento e reciclagem e maiores os benefícios socioambientais;

- Potencializadora: a coleta com separação de resíduos potencializa os benefícios da minimização de extrações de recursos naturais e do consumo de energia;

- Incorporadora: a execução da coleta de resíduos sólidos urbanos por empresas privadas de todos os portes (pequeno, médio e grande) e por outros atores sociais do terceiro setor (associações, cooperativas, ONGs, dentre outros) potencializa o aumento do número de empregos diretos do setor de resíduos sólidos. 
Para as políticas públicas e respectivos instrumentos legais e de planejamento em vigência para o gerenciamento integrado dos resíduos sólidos urbanos, foram selecionadas as seguintes variáveis:

- Recuperação de custos: a cobrança de taxa específica dos geradores de resíduos sólidos urbanos propicia maior consciência do gerador pois paga pelo quanto descarta e, consequentemente, é um estímulo à minimização;

- Existência de políticas públicas com obrigatoriedade de segregação na fonte geradora: a existência de instrumentos legais que determinam a obrigatoriedade de geradores segregar os resíduos sólidos na fonte geradora impulsiona toda a cadeira de resíduos, ao disponibilizar mais materiais para o mercado e forçar o poder público a proporcionar um sistema de gestão conveniente;

- Existência de planos e programas claros com metas: planos e programas de gerenciamento integrado de resíduos sólidos, com objetivos claros e definidos, metas factíveis, orçamento específicos e prestação de contas do cumprimento das metas à disposição dos cidadãos é fundamental para manter e/ou aumentar as taxas de reutilização e reciclagem dos resíduos sólidos urbanos;

- Existência de programas complementares de reutilização e reciclagem: quanto maior a quantidade de programas complementares de reutilização e reciclagem para diversos tipos de resíduos, maiores são as oportunidades de manter e/ou aumentar as taxas de desvio de resíduos de aterros sanitários;

- Divulgação de informação: a divulgação em massa das políticas públicas para reaproveitamento e reciclagem são fundamentais para conscientizar os geradores da importância da segregação dos resíduos sólidos urbanos na fonte geradora, pois mantém a participação da população constante. 
Para cada variável, foi construído critério de avaliação (Quadro 10 e Quadro 11).

Quadro 10 Critério de avaliação das variáveis para a coleta de resíduos sólidos com segregação na fonte geradora

\begin{tabular}{|c|c|}
\hline Variáveis & Critério de Avaliação \\
\hline Abrangência & $\begin{array}{l}\text { Nota máxima: a coleta de resíduos com separação na fonte geradora } \\
\text { está disponível para todos os geradores de resíduos sólidos urbanos } \\
\text { para três tipos de resíduos: recicláveis/secos, orgânicos e rejeitos } \\
\text { Nota média: a coleta de resíduos com separação na fonte geradora } \\
\text { está disponível para parte dos geradores de resíduos sólidos } \\
\text { urbanos para mais de um tipos de resíduos } \\
\text { Nota mínima: a coleta de resíduos com separação na fonte geradora } \\
\text { está disponível para parte dos geradores de resíduos sólidos } \\
\text { urbanos somente para um dos tipos de resíduos }\end{array}$ \\
\hline Frequência & $\begin{array}{l}\text { Nota máxima: a coleta de resíduos com separação na fonte geradora } \\
\text { ocorre initerruptamente, desde sua operacionalização e é constante; } \\
\text { ocorre mais de uma vez por semana em toda sua abrangência. } \\
\text { Nota média: a coleta de resíduos com separação na fonte geradora } \\
\text { ocorre ininterruptamente, desde sua operacionalização; é } \\
\text { constante/ocorre, no mínimo, uma vez por semana em toda sua } \\
\text { abrangência } \\
\text { Nota mínima: a coleta de resíduos com separação na fonte geradora } \\
\text { foi interrompida ao longo do período estudado por diversos fatores } \\
\text { operacionais e políticos }\end{array}$ \\
\hline Eficiência & $\begin{array}{l}\text { Nota máxima: a coleta de resíduos com separação na fonte geradora } \\
\text { proporciona o reaproveitamento e a reciclagem de três tipos de } \\
\text { resíduos: recicláveis/secos, orgânicos, rejeito } \\
\text { Nota média: a coleta de resíduos com separação na fonte geradora } \\
\text { proporciona o reaproveitamento e a reciclagem de, no mínimo, dois } \\
\text { tipos de resíduos } \\
\text { Nota mínima: a coleta de resíduos com separação na fonte geradora } \\
\text { proporciona o reaproveitamento e a reciclagem somente de um tipo } \\
\text { de resíduo }\end{array}$ \\
\hline Potencializadora & $\begin{array}{l}\text { Nota máxima: a coleta de resíduos com separação na fonte geradora } \\
\text { desvia do aterramento mais de } 50 \% \text { dos resíduos sólidos urbanos } \\
\text { gerados } \\
\text { Nota média: a coleta de resíduos com separação na fonte geradora } \\
\text { desvia do aterramento de } 10 \% \text { até } 50 \% \text { dos resíduos sólidos urbanos } \\
\text { gerados } \\
\text { Nota mínima: a coleta de resíduos com separação na fonte geradora } \\
\text { desvia do aterramento até } 10 \% \text { dos resíduos sólidos urbanos } \\
\text { gerados }\end{array}$ \\
\hline Incorporadora & $\begin{array}{l}\text { Nota máxima: a coleta de resíduos com separação na fonte geradora } \\
\text { é realizada por diversos atores sociais do terceiro setor }\end{array}$ \\
\hline
\end{tabular}




\begin{tabular}{|l|l|}
\hline \multicolumn{1}{|c|}{ Variáveis } & \multicolumn{1}{c|}{ Critério de Avaliação } \\
\hline & $\begin{array}{l}\text { (associações, cooperativas, ONGs, catadores independentes), } \\
\text { empresas de porte diversificado (pequeno, médio e grande), todos } \\
\text { geridos pelo poder público local, gerando mais oportunidades } \\
\text { econômicas na cadeia de reaproveitamento e reciclagem } \\
\text { Nota média: a coleta de resíduos com separação na fonte geradora é } \\
\text { realizada por empresas de médio e grande porte com a participação } \\
\text { do terceiro setor, geridos parcialmente pelo poder público local } \\
\text { Nota mínima: a coleta de resíduos com separação na fonte geradora } \\
\text { é realizada por empresas de grande porte sem participação do } \\
\text { terceiro setor }\end{array}$ \\
\hline
\end{tabular}

Elaboração: a autora

Quadro 11 Critério de avaliação de políticas públicas e instrumentos legais

\begin{tabular}{|c|c|}
\hline Variáveis & Critério de Avaliação \\
\hline $\begin{array}{l}\text { Recuperação de } \\
\text { custos }\end{array}$ & $\begin{array}{l}\text { Nota máxima: existe a cobrança de taxa de resíduos específica onde } \\
\text { o gerador pode efetuar o pagamento em função das quantidades } \\
\text { geradas. O não pagamento da taxa gera multas ao gerador. A } \\
\text { cobrança de taxa específica é diferenciada para os rejeitos } \\
\text { Nota média: existe a cobrança de taxa de resíduos específica onde } \\
\text { o gerador pode efetuar o pagamento em função das quantidades } \\
\text { geradas. O não pagamento da taxa gera multas ao gerador. } \\
\text { Nota mínima: não existe a cobrança de taxa de resíduos. A } \\
\text { recuperação de custos está inserida em outros impostos e/ou taxas. } \\
\text { O gerador não identifica o quanto paga pelos serviços de limpeza } \\
\text { urbana }\end{array}$ \\
\hline $\begin{array}{l}\text { Políticas } \\
\text { públicas com } \\
\text { obrigatoriedade } \\
\text { de segregação } \\
\text { na fonte } \\
\text { geradora }\end{array}$ & $\begin{array}{l}\text { Nota máxima: os geradores de resíduos sólidos urbanos são } \\
\text { obrigados a fazer a segregação dos resíduos na fonte geradora. A } \\
\text { fiscalização para o comprimento dos instrumentos legais é muito } \\
\text { atuante } \\
\text { Nota média: os geradores de resíduos sólidos urbanos são obrigados } \\
\text { a fazer a segregação dos resíduos na fonte geradora. A fiscalização } \\
\text { para o cumprimento dos instrumentos legais não é atuante } \\
\text { Nota mínima: não existe a obrigatoriedade junto aos geradores de } \\
\text { fazerem a segregação dos resíduos na fonte geradora }\end{array}$ \\
\hline $\begin{array}{l}\text { Planos e } \\
\text { programas } \\
\text { claros com } \\
\text { metas }\end{array}$ & $\begin{array}{l}\text { Nota máxima: os planos e programas existentes são executados } \\
\text { conforme previsto e são revisados conforme planejado. As } \\
\text { informações dos cumprimentos dos objetivos e metas são públicas e } \\
\text { avaliadas anualmente pelo poder público responsável. A prestação } \\
\text { de contas do orçamento gasto é compatível com o orçamento } \\
\text { previsto } \\
\text { Nota média: os planos e programas existentes nem sempre são } \\
\text { executados conforme previsto, bem como suas revisões são } \\
\text { realizadas conforme planejado. As informações dos cumprimentos } \\
\text { dos objetivos e metas são públicas, mediante a solicitação das } \\
\text { informações ao poder público responsável. A prestação de contas do }\end{array}$ \\
\hline
\end{tabular}




\begin{tabular}{|c|c|}
\hline Variáveis & Critério de Avaliação \\
\hline & $\begin{array}{l}\text { orçamento gasto, nem sempre é compatível com o orçamento } \\
\text { previsto } \\
\text { Nota mínima: os planos e programas existentes não executados } \\
\text { conforme previsto. As revisões dos planos e programas são } \\
\text { deficitárias pois não ocorrem nos períodos programados. As } \\
\text { informações dos cumprimentos dos objetivos e metas são de difícil } \\
\text { acesso ao público em geral. As avaliações que devem ser realizadas } \\
\text { anualmente pelo poder público responsável não estão disponíveis. A } \\
\text { prestação de contas do orçamento gasto nem sempre é compatível } \\
\text { com o orçamento previsto }\end{array}$ \\
\hline $\begin{array}{l}\text { Programas } \\
\text { complementares } \\
\text { de reutilização e } \\
\text { reciclagem }\end{array}$ & $\begin{array}{l}\text { Nota máxima: existem diversos programas complementares para a } \\
\text { coleta e recebimento de diversos tipos de resíduos, além daqueles } \\
\text { mais significativos (recicláveis/secos, orgânicos e rejeitos). Os } \\
\text { programas complementares estão disponíveis a todos os geradores, } \\
\text { sem cobrança específica. A participação do gerador em enviar } \\
\text { espontaneamente os resíduos específicos para os locais existentes é } \\
\text { prática comum. A disponibilidade é grande em todo o território do } \\
\text { município } \\
\text { Nota média: existem alguns programas complementares para a } \\
\text { coleta e recebimento de diversos tipos de resíduos, além daqueles } \\
\text { mais significativos (recicláveis/secos, orgânicos e rejeitos). Os } \\
\text { programas complementares estão disponíveis a boa parte dos } \\
\text { geradores, sem cobrança específica. A participação do gerador em } \\
\text { enviar espontaneamente os resíduos específicos para os locais } \\
\text { existentes é razoável } \\
\text { Nota mínima: existem poucos programas complementares para a } \\
\text { coleta e recebimento de diversos tipos de resíduos. Os programas } \\
\text { complementares têm pouca disponibilidade para todo o território. } \\
\text { Não há cobrança específica. A participação do gerador em enviar } \\
\text { espontaneamente os resíduos específicos para os locais existentes é } \\
\text { reduzida }\end{array}$ \\
\hline
\end{tabular}




\begin{tabular}{|c|c|}
\hline Variáveis & Critério de Avaliação \\
\hline Divulgação & $\begin{array}{l}\text { Nota máxima: estão disponíveis para todos os cidadãos, diversos } \\
\text { instrumentos de comunicação (vídeos, cartazes, cartilhas, dentre } \\
\text { outros) que esclarecem a obrigatoriedade da segregação dos } \\
\text { resíduos na fonte geradora. Existem diversos canais de comunicação } \\
\text { específicos (endereço eletrônico, telefone, formulários on line) para o } \\
\text { gerador conhecer detalhadamente como executar a separação de } \\
\text { resíduos, dicas de reutilização de embalagens, dentre outros. As } \\
\text { informações de coleta de resíduos estão centralizadas pelo poder } \\
\text { público num único endereço eletrônico ou telefone de contato } \\
\text { Nota média: estão disponíveis para todos os cidadãos, alguns } \\
\text { instrumentos de comunicação (vídeos, cartazes, cartilhas, dentre } \\
\text { outros) que esclarecem a obrigatoriedade da segregação dos } \\
\text { resíduos na fonte geradora. Existe pelo menos, um canal de } \\
\text { comunicação específico para o gerador conhecer detalhadamente } \\
\text { como executar a separação de resíduos, dicas de reutilização de } \\
\text { embalagens, dentre outros. As informações de coleta de resíduos } \\
\text { estão centralizadas pelo poder público num único endereço } \\
\text { eletrônico ou telefone de contato } \\
\text { Nota mínima: reduzido ou nenhum instrumento de comunicação } \\
\text { (vídeos, cartazes, cartilhas, dentre outros) para os cidadãos } \\
\text { conhecerem a correta segregação dos resíduos na fonte geradora. } \\
\text { Existe um canal de comunicação específico para o gerador conhecer } \\
\text { detalhadamente como executar a separação de resíduos. As } \\
\text { informações de coleta de resíduos estão pulverizadas nos endereços } \\
\text { eletrônicos ou telefones de contato das empresas concessionárias e } \\
\text { não possuem padrão de apresentação das informações educacionais }\end{array}$ \\
\hline
\end{tabular}

Elaboração: a autora 


\section{RESULTADOS}

$\mathrm{Na}$ sequência estão apresentados os resultados da pesquisa realizada nos três municípios estudados.

\subsection{SÃO FRANCISCO}

O município de São Francisco (Figura 14) situa-se no estado da Califórnia, na costa oeste dos Estados Unidos da América (Figura 15). O território municipal de São Francisco é formado pelos limites territoriais do condado 5 e do município (city) (NATIONAL LEAGUE OF CITIES, 2016).

Figura 14 Vista geral de São Francisco, Califórnia, Estados Unidos

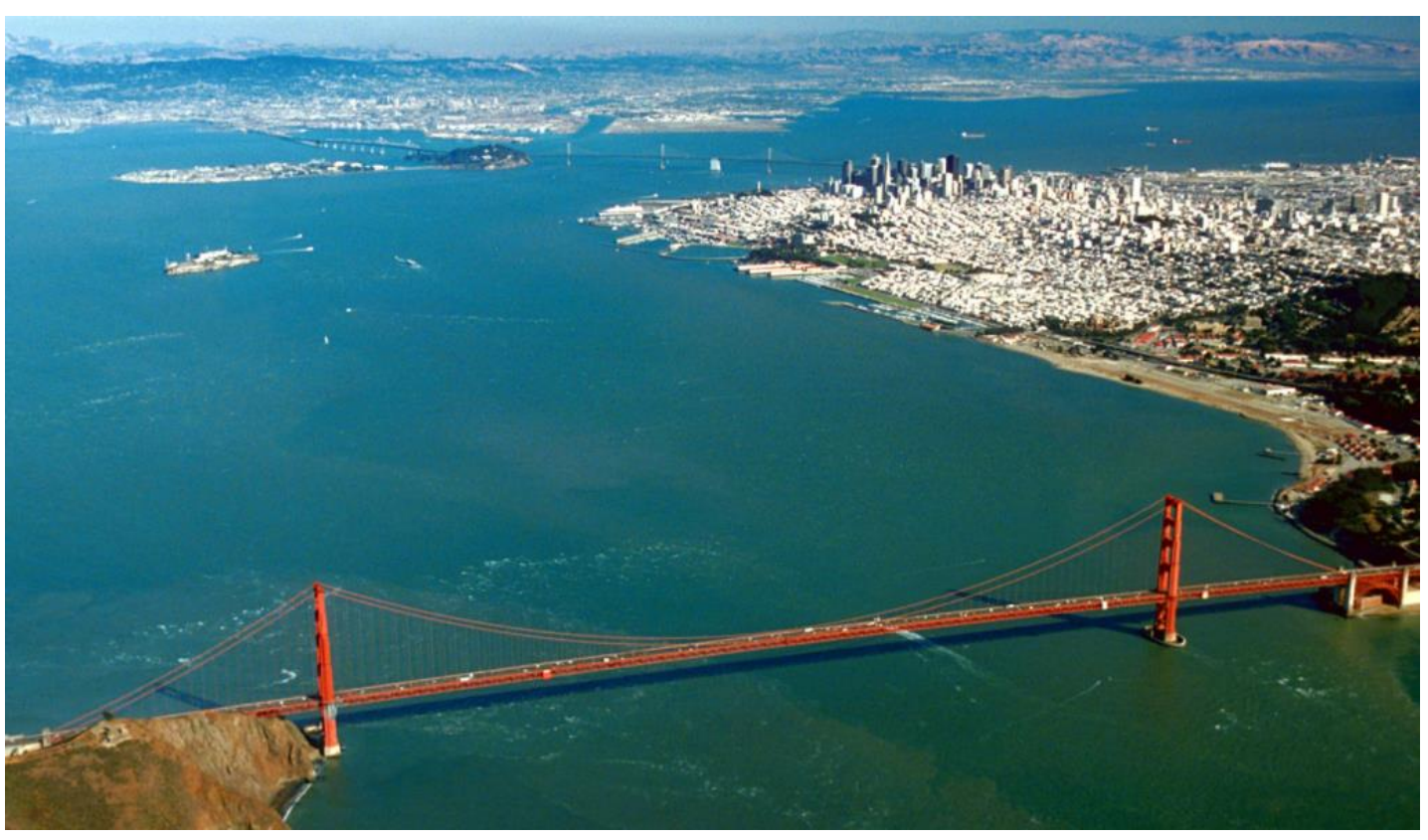

Fonte: https://www.pinterest.com/pin/446982331746275185/

\footnotetext{
${ }^{5}$ Os condados foram criados pelas constituições estaduais para servirem de braços administrativos dos governos estaduais. Os municípios geralmente estão dentro dos condados em termos geográficos e foram criados para deliberarem sobre os temas locais e possuem diversas funções administrativas tais como: fazer a gestão administrativa, criar as políticas municipais, definir orçamento, eleger o prefeito através do Conselho do Município, eleger os comissários para os diversos temas do município, dentre outros. Em São Francisco os limites do município e do condado foram consolidados. (NATIONAL LEAGUE OF CITIES, 2016).
} 
Figura 15 Localização geral de São Francisco, Califórnia, Estados Unidos

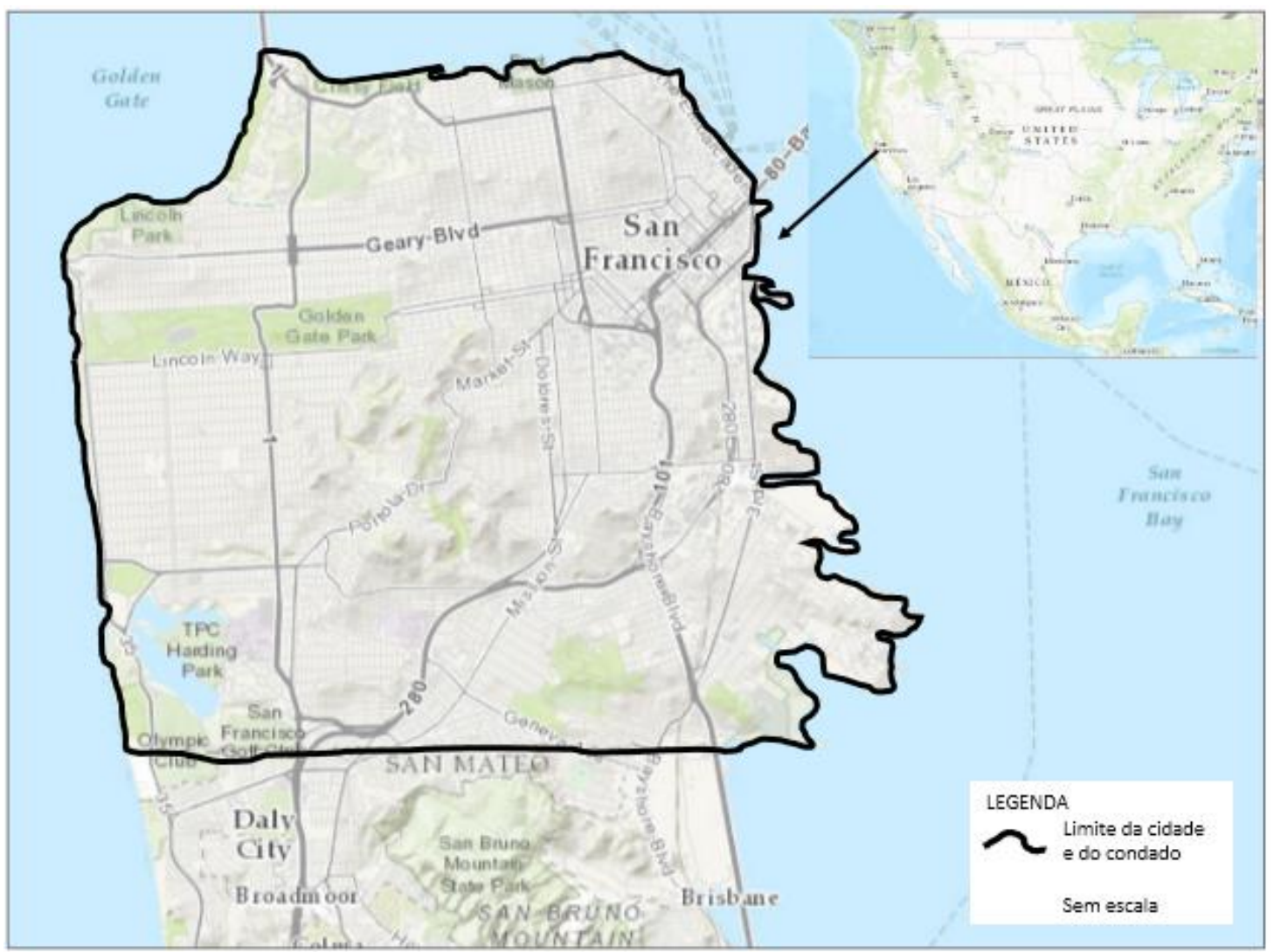

Fonte: City and County of San Francisco, Bureau of Land Management, 2012

Em 2015, São Francisco possuía uma população total de 864.816 habitantes, residindo em 390.204 habitações, todas situadas em área urbana, com densidade demográfica de 276,47 habitantes por quilômetro quadrado (Tabela 7). A renda familiar média anual, em 2010, foi de USD 71.304,00 e a renda per capita USD 45.478,00, acima da média nacional de USD 40.278,00 (UNITED STATES CENSUS BUREAU, 2016). 
Tabela 7 Caracterização de São Francisco, nos anos de 2000, 2010 e 2015

\begin{tabular}{l|c|c|c}
\hline \multirow{2}{*}{ Item } & \multicolumn{3}{|c}{ Ano } \\
\cline { 2 - 4 } & $\mathbf{2 0 0 0}$ & $\mathbf{2 0 1 0}$ & \multicolumn{1}{c}{$\mathbf{2 0 1 5}$} \\
\hline População total & $776.733,00$ & $805.235,00$ & $864.816,00$ \\
\hline Número de habitações & $346.527,00$ & $376.942,00$ & $390.204,00$ \\
\hline $\begin{array}{l}\text { Renda familiar média ano } \\
\text { (dólares) }\end{array}$ & $55.221,00$ & $71.304,00$ & $\ldots$ \\
\hline Renda per capita ano (dólares) & $34.556,00$ & $45.478,00$ & $\ldots$ \\
\hline
\end{tabular}

Fonte: United States Census Bureau, 2016

Nota: (...) Dado não disponível

No período de 2010 a 2014, São Francisco possuía 348.832 famílias, com média de 2,32 pessoas por família, sendo que $84,4 \%$ das famílias falavam outra língua em casa, além do inglês, e 86,7\% tinham nível secundário completo ou superior (UNITED STATES CENSUS BUREAU, 2016).

A existência de vários idiomas falados influenciou a elaboração de cartazes e cartilhas explicativas em 4 idiomas, utilizados nas campanhas de educação para a separação domiciliar e comercial dos resíduos sólidos urbanos.

\subsubsection{História e Tradição da Reciclagem em São Francisco}

O município de São Francisco, atualmente, é uma das cidades no mundo que possui mais altas taxas de reciclagem de resíduos sólidos urbanos, entretanto esta tradição pode ter começado há mais de um século, associada à própria história da cidade.

A região da baia de São Francisco, onde se situa São Francisco, foi uma área que ficou escondida por décadas, encoberta pelo nevoeiro, desde o período dos primeiros exploradores portugueses em 1542, a serviço da coroa espanhola, que navegaram nesta região, até o ano de 1769, quando exploradores espanhóis liderados por Gaspar Portolá adentraram na baia. Em 1776, os espanhóis construíram um forte e uma igreja, denominados Missión San Francisco, além de construírem um presídio para abrigar os nativos presos, 
usados como escravos para a construção do forte (THE SAN FRANCISCO PRESERVATION SOCIETY, 2016).

Por volta do início do século XIX, a região da baia de São Francisco passou a ser ocupada por criadores de gado que vieram da baixa Califórnia. Esta atividade atraiu novos colonos da região central dos Estados Unidos. Em 1846, mexicanos já independentes e americanos entraram em guerra pela posse das terras da Califórnia e, no mesmo período, foi descoberto ouro nas montanhas de Serra Nevada, fato que consolidou a região como zona portuária e de atração de ondas migratórias de todas as regiões do país e de outros países (THE SAN FRANCISCO PRESERVATION SOCIETY, 2016).

A coleta de resíduos sólidos em São Francisco foi iniciada no final do século XIX pelos imigrantes italianos que buscavam uma alternativa de sobrevivência, na catação de resíduos descartados pela população residente para comercialização (RECOLOGY SAN FRANCISCO, 2016a). Este serviço era realizado pelos imigrantes pois era considerado menos nobre e eles eram os catadores (em inglês, scavengers) que separavam materiais descartados que podiam ser comercializados, depois de limpos, lavados e consertados, tais como: garrafas de vidro, trapos de tecidos, papéis, embalagens reaproveitáveis como caixas de madeiras, lonas e outros materiais (RECOLOGY SAN FRANCISCO, 2016a). Os imigrantes e outros pequenos grupos de catadores se organizaram por volta dos anos 1920/21 (Figura 16) e fundaram duas empresas, a Scavenger's Protective Association e a Sunset Scavenger Company que receberam licenças da administração de São Francisco para executar os serviços de coleta de resíduos (RECOLOGY SAN FRANCISCO, 2016a).

Em 1935, estas duas empresas tornaram-se subsidiárias, formando a Sanitary Fill Company, responsável por toda a coleta, transporte, processamento e disposição final dos resíduos sólidos urbanos de São Francisco. Em 1965, a empresa Scavenger's Protective Association trocou de 
nome, como parte da estratégia de expansão e, para marcar uma nova fase, passou a se chamar Golden Gate Disposal \& Recycling Company (RECOLOGY SAN FRANCISCO, 2016b) (Figura 17).

Neste período, a empresa Sunset Scavenger operava o aterro sanitário no condado de San Mateo. Em 1983, a empresa Golden Gate se reestruturou novamente e passou a se chamar Norcal Solid Waste Systems, que foi vendida a seus funcionários em 1986 e, em 1987, comprou a empresa Envirocal formada pela Sunset Scavenger, tornando-se, na época, uma das 10 maiores empresas dos Estados Unidos, controlada $100 \%$ por seus funcionários. No início dos anos 1990, a Norcal adotou uma postura agressiva na modernização dos seus serviços e passou a ser a empresa pioneira na reciclagem de resíduos sólidos, antes mesmo da reciclagem tornar-se obrigatória por lei (RECOLOGY PENINSULA SERVICES, 2016b).

Em 2009, a Norcal passou a se comprometer com os princípios da sustentabilidade e, para marcar uma nova era, foi renomeada de Recology. Atualmente, a Recology atua em 127 cidades nos estados da Califórnia, Oregon, Washington e Nevada, ampliando sua influência e diretrizes (RECOLOGY SAN FRANCISCO, 2016b).

Figura 16 Coletores de resíduos Figura 17 Coleta de resíduos sólidos urbanos com carroças em São Francisco na década de 1920

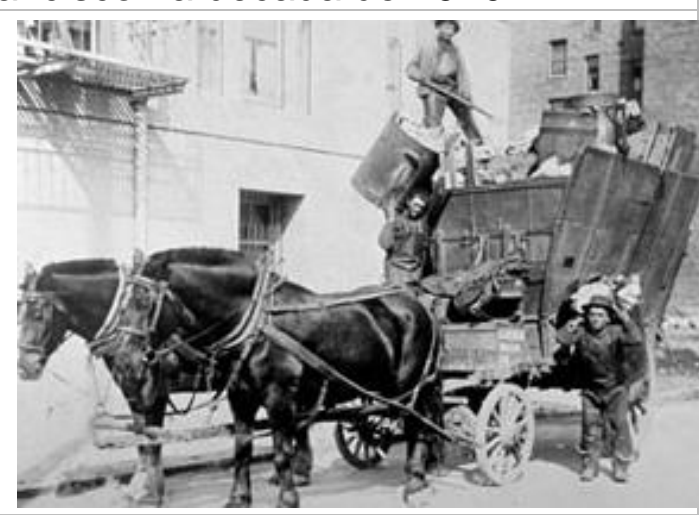

Fonte:recologypeninsulaservice.com/profile/his tory sólidos urbanos em caminhão em São Francisco na década de 1960

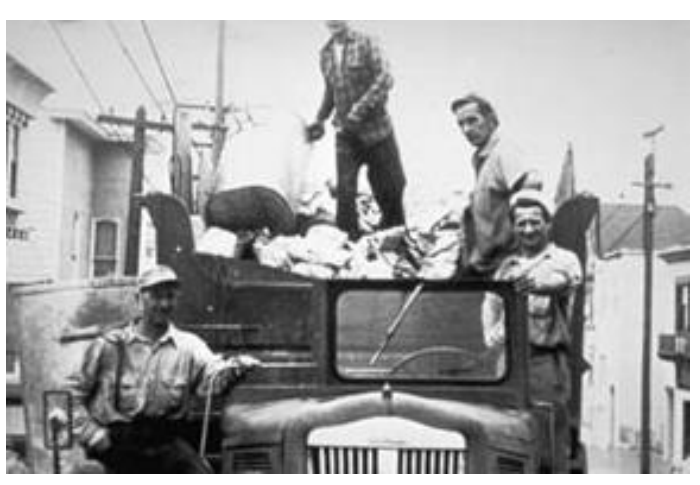

Fonte:recologypeninsulaservice.com/profile/his tory 


\subsubsection{Gerenciamento dos Resíduos Sólidos Urbanos de São Francisco}

Em São Francisco, não existe a coleta seletiva nos moldes como é realizada no Brasil, onde somente em alguns dias da semana, com equipamentos específicos, os resíduos sólidos secos são coletados. A coleta regular realizada com frequência semanal, recolhe em um mesmo caminhão, três categorias de resíduos: orgânicos, recicláveis e rejeito. A caçamba do veículo coletor possui compartimentos separados para descarregar os resíduos segregados nas residências, estabelecimentos comerciais, de serviços e das instituições em geral.

O gerenciamento integrado dos resíduos sólidos de São Francisco tem como foco a não geração, redução, reutilização e reciclagem e vem sendo executado pelo Departamento de Meio Ambiente de São Francisco, desde 2002, impulsionado pelos projetos de lei da Assembleia Legislativa do Estado da Califórnia. A publicação Boletim Administrativo n. 939 da Califórnia estabeleceu metas para desvio de resíduos de aterramento: (i) todos os municípios do estado deveriam deixar de enviar $25 \%$ dos seus resíduos para aterros sanitários até 1 de janeiro de 1995, (ii) até 1 de janeiro de 2000, deixar de enviar $50 \%$ do total de resíduos gerados para aterros (CALRECYCLE, 2015a).

Entretanto, a administração municipal de São Francisco sempre foi audaciosa ao longo dos últimos 15 anos, alcançando as metas estaduais com antecedência, estabelecendo metas mais restritivas. Em 2011, o governo estadual estipulou que, no ano 2020, os municípios da Califórnia deverão deixar de enviar 75\% dos resíduos sólidos gerados para aterros sanitários. Em 2014, São Francisco já havia ultrapassado esta meta (KATZ, 2014) e propôs a ampliação da meta no período: em 2020, nenhuma quantidade de resíduos sólidos será aterrada, ou seja, o princípio do aterro zero (COUNTY AND CITY OF SAN FRANCISCO, 2003). 
A meta de não enviar nenhuma quantidade de resíduos sólidos para aterros sanitários foi estabelecida em 2003 e ficou conhecida na cidade de São Francisco como Lixo Zero ou em inglês "Zero Waste" (COUNTY AND CITY OF SAN FRANCISCO, 2003).

Para alcançar a meta de Lixo Zero, São Francisco criou, em 2009, pela Portaria n. $-100-09$, a obrigatoriedade a todos os munícipes, inclusive turistas, de separarem seus resíduos sólidos em três categorias na fonte de geração (COUNTY AND CITY OF SAN FRANCISCO, 2009).

Além desta diretiva, São Francisco implementou programas complementares e estabeleceu instrumentos legais que disciplinaram políticas públicas municipais que abordaram, desde 0 estabelecimento da responsabilidade compartilhada do produtor até a restrição da utilização de certos materiais (isopor, plásticos e similares) cujo processo de reciclagem é de difícil realização, ou não está disponível nas unidades de processamento dos resíduos da cidade, ou são considerados altamente poluentes, quando dispostos em aterros sanitários. Estes procedimentos serão apresentados em detalhe em itens subsequentes.

As categorias de separação obrigatórias em São Francisco estão apresentadas no Quadro 12 (CITY AND COUNTY OF SAN FRANCISCO, 2012a).

Quadro 12 Categorias de separação dos resíduos sólidos urbanos, categorias em São Francisco, Estados Unidos

\begin{tabular}{|c|c|c|c|}
\hline $\begin{array}{l}\text { Categorias } \\
\text { de Resíduos } \\
\text { Sólidos }\end{array}$ & $\begin{array}{l}\text { Composição } \\
\text { Predominante }\end{array}$ & $\begin{array}{l}\text { Tratamento e/ou } \\
\text { Disposição Final }\end{array}$ & $\begin{array}{c}\text { Cor } \\
\text { Contentor }\end{array}$ \\
\hline Recicláveis & $\begin{array}{l}\text { Papel, plásticos, } \\
\text { metais, vidro }\end{array}$ & $\begin{array}{lr}\text { Central rel } & \text { de } \\
\text { Reciclagem no Pier } \\
96\end{array}$ & Azul \\
\hline Orgânicos & $\begin{array}{l}\text { Restos de alimentos, } \\
\text { papel sujo e vegetais } \\
\text { de poda de jardim }\end{array}$ & $\begin{array}{l}\text { Central } \\
\text { compostagem }\end{array}$ & Verde \\
\hline
\end{tabular}




\begin{tabular}{|l|l|l|c|}
\hline $\begin{array}{l}\text { Categorias } \\
\text { de Resíduos } \\
\text { Sólidos }\end{array}$ & \multicolumn{2}{|c|}{$\begin{array}{c}\text { Composição } \\
\text { Predominante }\end{array}$} & \multicolumn{2}{|l|}{$\begin{array}{l}\text { Tratamento e/ou } \\
\text { Disposição Final }\end{array}$} & $\begin{array}{c}\text { Cor } \\
\text { Contentor }\end{array}$ \\
\hline Rejeitos & $\begin{array}{l}\text { Materiais não } \\
\text { reaproveitados }\end{array}$ & $\begin{array}{l}\text { Transbordo e aterro } \\
\text { sanitário San } \\
\text { Francisco }\end{array}$ & Preto \\
\hline
\end{tabular}

Fonte: City and County of San Francisco. The Department of The Environment, 2012

Todas as residências recebem três contentores de cores diferentes (azul, verde e preto), com tamanho (121 litros) e forma padronizados, que facilitam o gerenciamento das quantidades de resíduos sólidos urbanos (Figura 18 e Figura 19). Em 2018, os tamanhos dos contentores passaram a ser diferenciados: (i) verde para orgânicos têm capacidade de 121 litros; (ii) o azul para resíduos recicláveis (secos) passou para 242 litros; (iii) e, o preto, para rejeitos que são enviados para aterros, passou para 60 litros. Esta foi uma forma para aumentar o estimulo à separação na fonte geradora. Os estabelecimentos públicos e comerciais recebem contentores para maiores quantidades de armazenamento de resíduos.

Além disto, a utilização de contentores minimiza o uso de muitos sacos plásticos para estocar os resíduos sólidos e permite gerenciar melhor as quantidades permitidas de descarte de resíduos que são proporcionais às tarifas pagas pelos munícipes. O programa de distribuição dos 3 contentores para os domicílios, comércio e estabelecimentos públicos foi denominado de "Os Três Fantásticos" (3 Fantastic), iniciado como projeto piloto em 1999, conforme informações obtidas no levantamento de campo. 
Figura 18: Contentores utilizados para separação dos resíduos sólidos urbanos em São Francisco
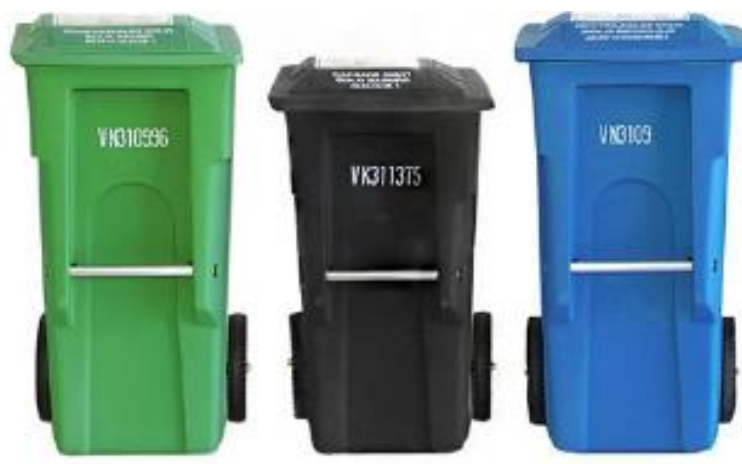

Fonte: sfenvironment.org/article/residentialrecycling-and-composting/recycling-compostingrequirements-for-residents
Figura 19: Contentores diferenciados para coleta de resíduos sólidos urbanos em residências em São Francisco

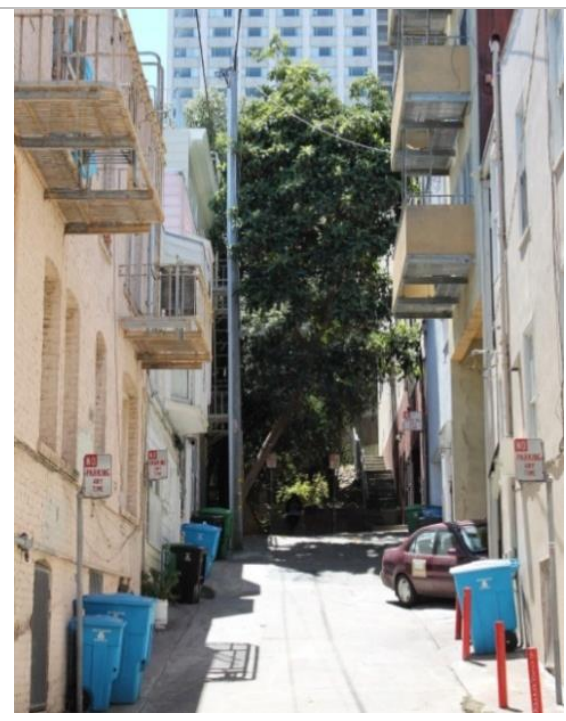

Fonte: Levantamento de Campo, 2014. Da autora

Os contentores são elementos integrantes do sistema de coleta, uma vez que são projetados para serem recolhidos por sistema automatizado do caminhão que conecta uma garra ao contentor e descarrega o conteúdo em uma de suas partes, de acordo com o tipo de resíduo. Os resíduos sólidos que podem ser depositados em cada contentor estão apresentados em detalhe no Quadro 13.

Quadro 13 Composição dos resíduos por categorias de separação, em São Francisco, Estados Unidos

\begin{tabular}{|l|c|l|}
\hline $\begin{array}{l}\text { Categorias } \\
\text { de } \\
\text { separação }\end{array}$ & $\begin{array}{l}\text { Composição } \\
\text { Predominante }\end{array}$ & \multicolumn{1}{|c|}{ Tipos de Materiais } \\
\hline Recicláveis & Papel limpo & $\begin{array}{l}\text { Todo tipo de papel limpo e seco: papelão (não- } \\
\text { encerado), caixas de cereais (sem forro de plástico), } \\
\text { caixas de ovos, envelopes, caixas de papel diversas, } \\
\text { sacolas de papel, revistas, jornais, blocos de } \\
\text { anotações, papel picado, etiqueta de papel, papel de } \\
\text { embrulho (não metálicos) }\end{array}$ \\
\hline
\end{tabular}




\begin{tabular}{|c|c|c|}
\hline $\begin{array}{l}\text { Categorias } \\
\text { de } \\
\text { separacão }\end{array}$ & $\begin{array}{l}\text { Composição } \\
\text { Predominante }\end{array}$ & Tipos de Materiais \\
\hline & Vidro & $\begin{array}{l}\text { Garrafas, copos, embalagens em geral de vidro } \\
\text { (frascos) }\end{array}$ \\
\hline & Metal & $\begin{array}{l}\text { Latas de alumínio, folhas de alumínio, bandejas de } \\
\text { alumínio, tampas de metal, tampa de lata de tinta } \\
\text { (deve estar vazia ou seca), embalagem de aerossol } \\
\text { (deve estar vazia) }\end{array}$ \\
\hline & Plástico & $\begin{array}{l}\text { Garrafas (sem tampas), baldes (pode deixar alça de } \\
\text { metal), tampas do copo de café, recipientes de } \\
\text { plástico em geral, conchas, rolhas de plástico, copos } \\
\text { e pratos de plástico (sem isopor), vasos de flores de } \\
\text { plástico, brinquedos (sem componentes eletrônicos, } \\
\text { metais ou baterias), banheiras e tampas plásticas em } \\
\text { geral }\end{array}$ \\
\hline \multirow{4}{*}{ Orgânicos } & $\begin{array}{l}\text { Restos } \\
\text { alimentos }\end{array}$ & $\begin{array}{l}\text { Sobras e comida estragada, carne (incluindo ossos), } \\
\text { frutos do mar (incluindo crustáceos), frutas e } \\
\text { vegetais (incluindo caroços e cascas), borra de café } \\
\text { e filtro de papel, produtos lácteos (não líquidos), } \\
\text { ovos e suas cascas }\end{array}$ \\
\hline & $\begin{array}{c}\text { Vegetais de } \\
\text { poda de jardim }\end{array}$ & $\begin{array}{l}\text { Ramos, flores, enfeites florais, gramíneas, ervas } \\
\text { daninhas, folhas, troncos de árvores (menos de } 15 \\
\mathrm{~cm} \text { de diâmetro e } 121 \mathrm{~cm} \text { de comprimento) }\end{array}$ \\
\hline & Papel sujo & $\begin{array}{l}\text { Filtros de café, sache de chás, caixas de pizza } \\
\text { engordurada, sacos de papel, copos e pratos de } \\
\text { papel, recipientes de sorvete de papel, guardanapos } \\
\text { e lenços de papel, toalhas de papel, embalagens de } \\
\text { papel em geral, embalagens de papel de comida } \\
\text { pronta, embalagens de papel de leite e caixas de } \\
\text { suco }\end{array}$ \\
\hline & $\begin{array}{c}\text { Outros } \\
\text { compostáveis }\end{array}$ & $\begin{array}{l}\text { Sacos rotulados como compostáveis, rolhas de } \\
\text { cortiça naturais, algodão, cotonetes com hastes } \\
\text { papel, cabelo, pele e penas (não sintético/não } \\
\text { colorido), plástico identificado como compostável, } \\
\text { caixas de madeira vegetal, papelão encerado. } \\
\text { Madeira: pequenos pedaços de madeira limpa, } \\
\text { serragem limpa, pauzinhos de madeira, agitadores } \\
\text { de café, palitos }\end{array}$ \\
\hline
\end{tabular}




\begin{tabular}{|c|c|c|}
\hline $\begin{array}{l}\text { Categorias } \\
\text { de } \\
\text { separacão }\end{array}$ & $\begin{array}{l}\text { Composição } \\
\text { Predominante }\end{array}$ & Tipos de Materiais \\
\hline Rejeitos & $\begin{array}{l}\text { Materiais não } \\
\text { reaproveitados }\end{array}$ & $\begin{array}{l}\text { Louça, cerâmica ou pedaços de vidro, fraldas e } \\
\text { absorventes, sacos com alumínio (salgadinho), vidro } \\
\text { (exceto garrafas e frascos), embalagens de suco } \\
\text { e/ou leite forradas com alumínio e plástico, caixas } \\
\text { com forro da folha em plástico, lâmpadas } \\
\text { incandescentes, itens de plástico fabricados e } \\
\text { misturados com metal, tecido ou borracha, luvas de } \\
\text { borracha ou látex }\end{array}$ \\
\hline
\end{tabular}

Fonte: County and City of San Francisco, 2009

O detalhamento do conteúdo que cada contentor pode receber faz parte do material educativo distribuído pela Recology e pelo Departamento de Meio Ambiente de São Francisco e são disponibilizados no website de ambas instituições.

As unidades de recepção, tratamento e/ou destinação final de São Francisco estão apresentadas no Quadro 14.

Quadro 14 Unidades receptoras de RSU de São Francisco em 2018, Estados Unidos

\begin{tabular}{|l|c|}
\hline Unidade & Quantidade \\
\hline $\begin{array}{l}\text { Transbordo/San Francisco Transfer Station - Tunnel Avenue, } \\
\text { São Francisco (Figura 21 e Figura 22) }\end{array}$ & 1 \\
\hline $\begin{array}{l}\text { Central de Separação de Recicláveis/Recycle Central/Pier 96 - } \\
1000 \text { Amador Street, São Francisco (Figura 27) }\end{array}$ & 1 \\
\hline $\begin{array}{l}\text { Unidade de recepção de resíduos orgânicos - Tunnel Avenue, } \\
\text { São Francisco (Figura 28) }\end{array}$ & 1 \\
\hline Aterro Sanitário Recology - Hay Road, Vacaville & 1 \\
\hline Unidade de compostagem Jepson Prairie, Vacaville & 1 \\
\hline $\begin{array}{l}\text { Elaboração: a autora } \\
\text { O fluxograma de origem e destino dos resíduos sólidos urbanos de São } \\
\text { Francisco está apresentado na Figura 20 a seguir. }\end{array}$ \\
\hline
\end{tabular}


Figura 20 Fluxograma de origem e destino dos resíduos sólidos urbanos de São Francisco, 2016

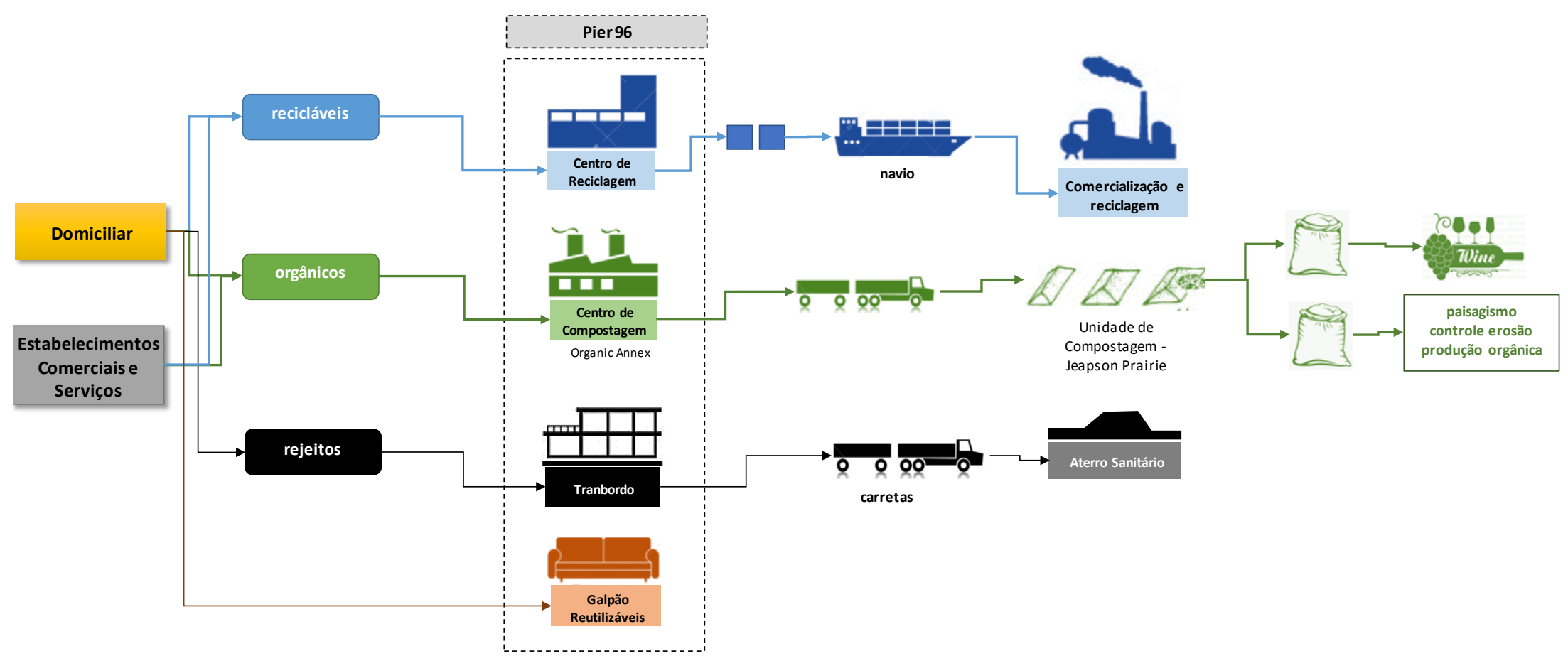

Fonte: Levantamento de Campo, 2014

Elaboração: a autora 
Figura 21 Carretas de transbordo Figura 22 Área portuária de de materiais recicláveis e orgânicos embarque de contêineres com que são enviados para porto para materiais recicláveis secos prontos comercialização ou planta de para comercialização compostagem. Pier 96

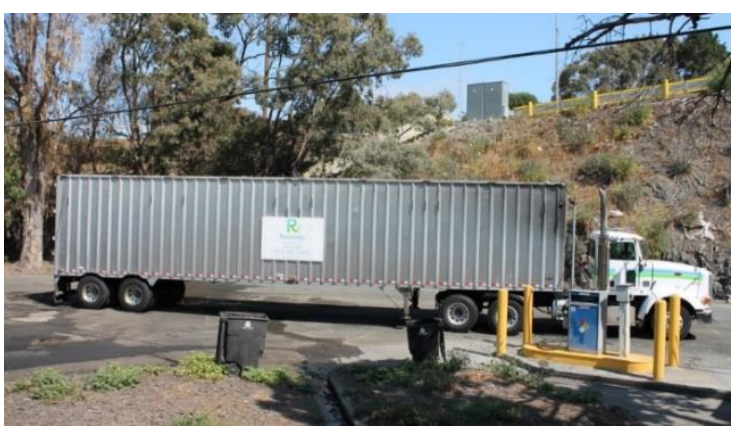

Fonte: levantamento de campo, 2014. Da autora

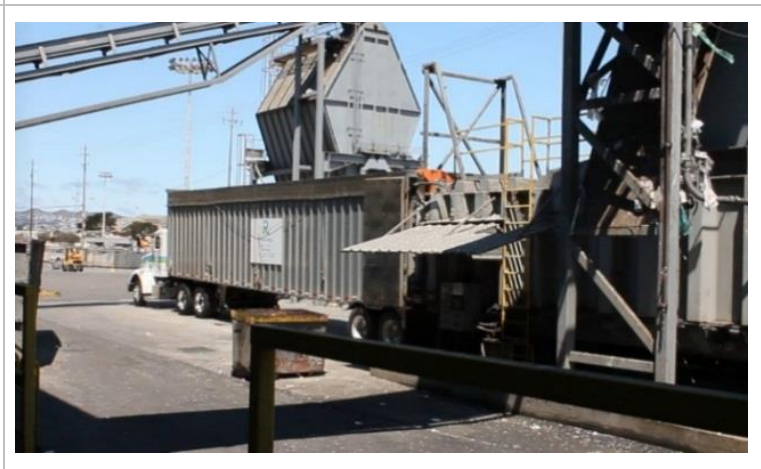

Fonte: levantamento de campo, 2014. Da autora
Figura 23 Central mecanizada de triagem de resíduos sólidos recicláveis/secos. Pier 96

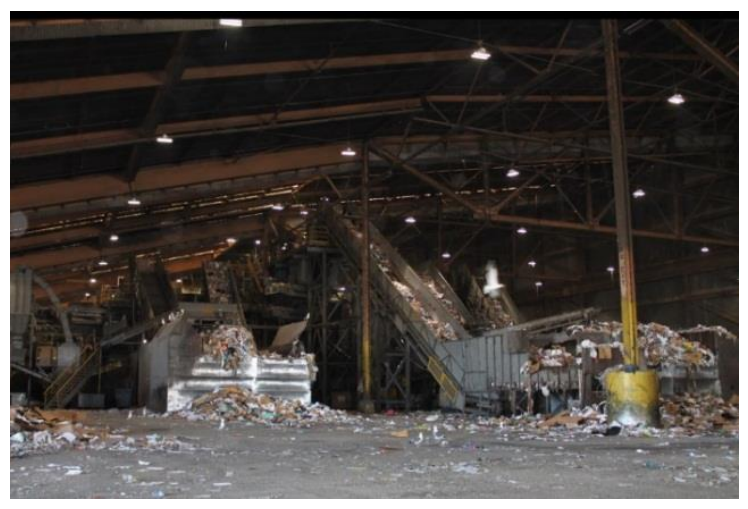

Fonte: levantamento de campo, 2014. Da autora

Figura 24 Galpão de orgânicos que
recebe materiais que são
transportados por carretas para
compostagem

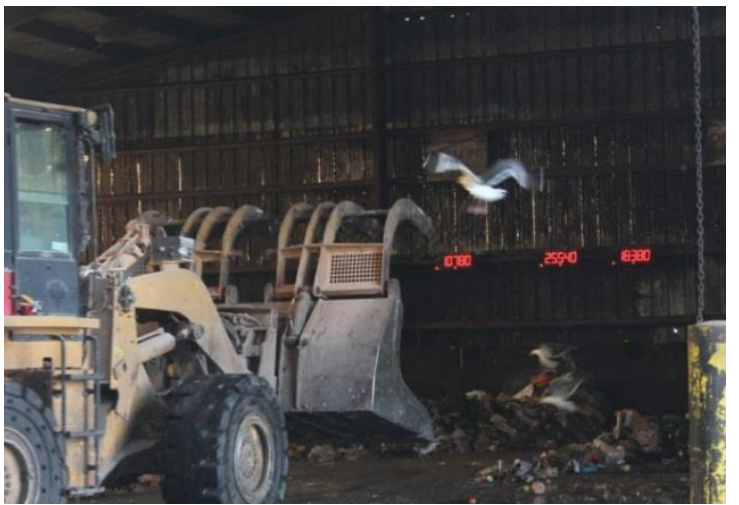

Fonte: levantamento de campo, 2014. Da autora

Em termos de quantidades totais de resíduos sólidos gerados, coletados e enviados para disposição final, o município de São Francisco vem diminuindo paulatinamente as quantidades que são enviadas para aterros sanitários, em função da execução de ações que visam cumprir as políticas públicas 
estabelecidas pelo município e pelo governo da Califórnia. Conforme pode ser observado na Tabela 8, do total dos resíduos sólidos gerados em São Francisco, 23\% são resíduos domiciliares. No período entre 2003 e 2006 já se constata uma redução média de $37 \%$ em relação ao total gerado e às quantidades de resíduos sólidos dispostas em aterros sanitários.

Esta redução é o reflexo positivo do cumprimento das metas das políticas públicas do estado (Lei de Gestão Integrada de Resíduos, AB 939/89, capítulo 1095 do Estado da Califórnia de 1989) de redução do volume de resíduos enviados para aterros. No caso de São Francisco, isto significou que os resíduos desviados dos aterros foram enviados para algum processo de reutilização e/ou reciclagem.

Tabela 8 Quantidades totais de resíduos sólidos gerados, aterrados e desviados de aterros sanitários para São Francisco, entre 2003 e 2006

\begin{tabular}{l|r|r|r|r}
\hline Item & \multicolumn{1}{|c|}{2003} & \multicolumn{1}{|c|}{2004} & \multicolumn{1}{c|}{2005} & \multicolumn{1}{c|}{2006} \\
\hline Geração Total Resíduos (t) & 1.843 .338 & 1.843 .338 & 1.892 .506 & 1.892 .506 \\
\hline $\begin{array}{l}\text { Taxa de Resíduos } \\
\text { Domiciliares (\%) }\end{array}$ & 23 & 23 & 23 & 23 \\
\hline $\begin{array}{l}\text { Geração Resíduos } \\
\text { Domiciliares (t) }\end{array}$ & 423.968 & 423.968 & 435.276 & 435,276 \\
\hline $\begin{array}{l}\text { Geração Resíduos Não } \\
\text { Domiciliar (t) }\end{array}$ & 1.419 .370 & 1.419 .370 & 1.457 .230 & 1.457 .230 \\
\hline $\begin{array}{l}\text { Quantidade Total Resíduos } \\
\text { Disposta em Aterro (t) }\end{array}$ & 718.931 & 691.679 & 675.326 & 695.640 \\
\hline $\begin{array}{l}\text { Quantidade de Resíduos } \\
\text { Desviada de Aterro (t) }\end{array}$ & 132.384 & 62.600 & 63.591 & 76.818 \\
\hline $\begin{array}{l}\text { Saldo da Quantidade Total } \\
\text { Resíduos (t) }\end{array}$ & 586.547 & 629.079 & 611.735 & 618.822 \\
\hline $\begin{array}{l}\text { Fonte:www.calrecycle.ca.gov/LGCentral/Reports/diversionprogram/JurisdictionDiversionDetail.a } \\
\text { spx?JurisdictionID=438, 2018 }\end{array}$ & & &
\end{tabular}

Cabe destacar que, apesar desta pesquisa investigar o período entre 2006 e 2016 para as taxas de reciclagem de resíduos sólidos urbanos, até o presente momento, não foi possível obter os dados específicos de resíduos sólidos domiciliares para a série histórica de 10 anos e, então, utilizou-se como 
referência para identificar as quantidades de resíduos domiciliares, os 4 anos anteriores apresentados na Tabela 8.

No endereço eletrônico do governo estadual da Califórnia (http://www.calrecycle.ca.gov) é possível monitorar o cumprimento de todas as metas de desvio de resíduos de aterros que foram estabelecidas nas políticas públicas. Neste mesmo endereço eletrônico, os municípios devem preencher seus formulários conforme modelos estabelecidos pelo governo estadual e, assim, demonstrar o cumprimento das metas estabelecidas.

Conforme pode ser observado na Tabela 9, obtida a partir de contatos formais com o representante do Departamento de Meio Ambiente de São Francisco, as metas de diminuição das quantidades de resíduos sólidos totais enviadas para os aterros sanitários (desvio de resíduos para aterros) vem sendo alcançadas conforme previsto nas políticas públicas municipais de São Francisco onde a coluna taxa de recuperação mostra a taxa total de resíduos sólidos recuperados por ano.

Tabela 9 Quantidades totais de resíduos sólidos gerados, recuperados, em São Francisco, entre 2006 e 2014

\begin{tabular}{l|c|r|r}
\hline Ano & $\begin{array}{c}\text { Geração Total de } \\
\text { Resíduos Sólidos } \\
(\mathbf{t})\end{array}$ & $\begin{array}{c}\text { Quantidades de } \\
\text { Resíduos } \\
\text { Recuperados (t) }\end{array}$ & \multicolumn{2}{|c}{$\begin{array}{c}\text { Taxa de } \\
\text { Recuperação } \\
(\%)\end{array}$} \\
\hline 2006 & 2.033 .980 & 1.415 .158 & $70 \%$ \\
\hline 2007 & 2.100 .943 & 1.517 .849 & $72 \%$ \\
\hline 2008 & 2.142 .671 & 1.641 .252 & $77 \%$ \\
\hline 2009 & 1.983 .934 & 1.550 .046 & $78 \%$ \\
\hline 2010 & 2.000 .214 & 1.593 .830 & $80 \%$ \\
\hline 2011 & 2.154 .476 & 1.764 .955 & $82 \%$ \\
\hline 2012 & 2.255 .812 & 1.871 .251 & $83 \%$ \\
\hline 2013 & 2.672 .124 & 2.260 .708 & $85 \%$ \\
\hline 2014 & 2.875 .078 & 2.424 .608 & $84 \%$ \\
\hline 2016 & $\ldots$ & $\ldots$ & $\ldots$ \\
\hline
\end{tabular}

Fonte: San Francisco Department of the Environment. Commercial Zero Waste Coordinator Nota: (...) Dado não disponível 
A partir dos dados quantitativos da tabela anterior e considerando que no período da pesquisa, os resíduos domiciliares representaram $23 \%$ do total de resíduos gerados em São Francisco se mantiveram na mesma proporção, conforme informações obtidas com o Departamento de Meio Ambiente, foi possível calcular as quantidades de resíduos domiciliares, apresentadas na Tabela 10.

Tabela 10 Estimativa de resíduos sólidos domiciliares produzidos São Francisco, em toneladas, entre 2006 e 2014

\begin{tabular}{l|c|c}
\hline Ano & $\begin{array}{c}\text { Total Gerado } \\
\text { Resíduos } \\
\text { Sólidos (t) }\end{array}$ & $\begin{array}{c}\text { Estimativa do Total de Resíduos Sólidos } \\
\text { Domiciliares (t) }\end{array}$ \\
\hline 2006 & 2.033 .980 & $467.815,40$ \\
\hline 2007 & 2.100 .943 & $483.216,89$ \\
\hline 2008 & 2.142 .671 & $492.814,33$ \\
\hline 2009 & 1.983 .934 & $456.304,82$ \\
\hline 2010 & 2.000 .214 & $460.049,22$ \\
\hline 2011 & 2.154 .476 & $495.529,48$ \\
\hline 2012 & 2.255 .812 & $518.836,76$ \\
\hline 2013 & 2.672 .124 & $614.588,52$ \\
\hline 2014 & 2.875 .078 & $661.267,94$ \\
\hline 2015 & $\ldots$ & $\ldots$ \\
\hline 2016 & $\ldots$ & $\ldots$ \\
\hline
\end{tabular}

Fonte: Adaptado de San Francisco Department of the Environment. Commercial Zero Waste Coordinator.

Nota: (...) Dado não disponível

Parte dos tipos de resíduos sólidos coletados e processados nas unidades da empresa Recology entre o período de 01 de julho de 2014 a 30 de junho de 2016 estão apresentados na Tabela 11. Conforme pode ser observado, os rejeitos que são armazenados (contentores preto) tiveram as menores taxas de desvio do aterramento, quando comparado aos resíduos orgânicos (contentor verde) e recicláveis (contentor azul), que tiveram as medias para os dois periodos de $97 \%$ e $83 \%$, respectivamente, demonstrando a eficiencia dos sistemas de separação e processamento destes dois tipos de residuos. 
Tabela 11 Tipos de resíduos recebidos pela Recology, desviados do aterramento, disposto em aterro e taxa de desvio entre 1 de julho de 2014 a 30 de junho de 2016, São Francisco

\begin{tabular}{|l|r|r|r|r|r|r|r|r|}
\hline \multirow{2}{*}{$\begin{array}{c}\text { Tipo de } \\
\text { Resíduos }\end{array}$} & \multicolumn{2}{|c|}{ de 1 Julho 2014 a 30 Junho 2015} & \multicolumn{2}{|c|}{ de 1 Julho 2015 a 30 Junho 2016} \\
\cline { 2 - 9 } & $\begin{array}{c}\text { Recebido } \\
\text { (t) }\end{array}$ & $\begin{array}{c}\text { Desviado } \\
\text { (t) }\end{array}$ & $\begin{array}{c}\text { Disposto } \\
\text { (t) }\end{array}$ & $\begin{array}{c}\text { Desvio } \\
\text { \% }\end{array}$ & $\begin{array}{c}\text { Recebido } \\
\text { (t) }\end{array}$ & $\begin{array}{c}\text { Desviado } \\
\text { (t) }\end{array}$ & $\begin{array}{c}\text { Disposto } \\
\text { (t) }\end{array}$ & $\begin{array}{c}\text { Desvio } \\
\%\end{array}$ \\
\hline Rejeito & 261.418 & 730 & 260.688 & 0,3 & 269.223 & 53 & 269.171 & 0 \\
\hline $\begin{array}{l}\text { Orgânicos/ } \\
\text { Compostagem }\end{array}$ & 173.505 & 166.647 & 6.858 & 96 & 147.749 & 164.067 & 10.682 & 94 \\
\hline Recicláveis & 161.801 & 137.377 & 24.424 & 85 & 162.828 & 141.902 & 20.926 & 87 \\
\hline
\end{tabular}

Fonte: San Francisco Annual Rate Reports: Year Ended June 30, 2015; Ended June 30, 2016. Department of Public Works Director's Report.

$\mathrm{Na}$ composição gravimétrica dos resíduos sólidos urbanos de São Francisco, os resíduos orgânicos representam 33\% e os recicláveis (papel, plástico, metais e vidro) representam $42,30 \%$ (Tabela 12).

Tabela 12 Composição gravimétrica dos resíduos sólidos urbanos recebidos no aterro Norcal provenientes da coleta de resíduos sólidos urbanos de São Francisco em 2006

\begin{tabular}{lrr}
\multicolumn{1}{c}{ Material } & \multicolumn{1}{c}{ Toneladas } & $\%$ \\
\hline Orgânicos & $170.305,00$ & 33,00 \\
\hline Papel & $125.177,00$ & 24,30 \\
\hline Entulho & 62,78 & 12,20 \\
\hline Plástico & $54.316,00$ & 10,50 \\
\hline Outros Materiais & $49.015,00$ & 9,50 \\
\hline Metais & 21,91 & 4,20 \\
\hline Vidro & $17.142,00$ & 3,30 \\
\hline Resíduos perigosos (1) & 15,02 & 2,90 \\
\hline Total & $\mathbf{5 1 5 . 6 6 4 , 0 0}$ & $\mathbf{1 0 0 , 0 0}$ \\
\hline
\end{tabular}

Fonte: City and County of San Francisco Department of the Environment, Attachment A. 2006 Nota: (1) Resíduos perigosos: as medições de resíduos perigosos incluem os pesos dos recipientes que contêm esses resíduos

Em 2016, os resíduos sólidos orgânicos provenientes da coleta domiciliar e estabelecimentos comerciais (bares, restaurantes, mercearias, eventos, etc.) corresponderam a coleta em 165.000 unidades que produziram cerca de 600 toneladas/dia e foram transportados por 49 caminhões compactadores e transportados até o Galpão de Orgânicos (Tunnel Avenue ou Pier 96 em São 
Francisco) (RECOLOGY ORGANICS WASTE ZERO, 2016). Os caminhões descarregam os resíduos orgânicos no fosso do Galpão e, posteriormente, são transportados por carretas de maior capacidade (24,5 toneladas) para a unidade de compostagem Jepson Prairie Organics, em Vacaville, a 100 quilômetros do Galpão de Orgânicos (RECOLOGY ORGANICS WASTE ZERO, 2016d).

De acordo com dados de 2016, a unidade de compostagem Jepson Prairie processou cerca de 100.000/toneladas/mês de resíduos orgânicos, gerados em São Francisco e em outras cidades do entorno da Baia de São Francisco. A produção de composto orgânico envolve resíduos advindos de: (i) restos de alimentos de restaurantes, hotéis, mercados, cafés e (ii) resíduos de podas de árvores e jardins. Estes resíduos são homogeneizados em um misturador para alcançarem proporções ideais dos diferentes materiais orgânicos para 0 processo de decomposição biológica e, posteriormente, são encaminhados para o biodigestor (Engineered Compost System - ECS). O material permanece no biodigestor por um período de 30 a 45 dias, onde as condições de oxigênio, temperatura e umidade são controladas e monitoradas. Após esta etapa, o composto é levado para um pátio de cura, onde são formadas pilhas e, após conferência da qualidade, o composto é ensacado e comercializado. A Figura 25 apresenta uma visão geral da unidade de compostagem Jepson Prairie (RECOLOGY ORGANICS WASTE ZERO, 2016d).

Figura 25 Vista geral da unidade de compostagem de Jepson Prairie, 2016

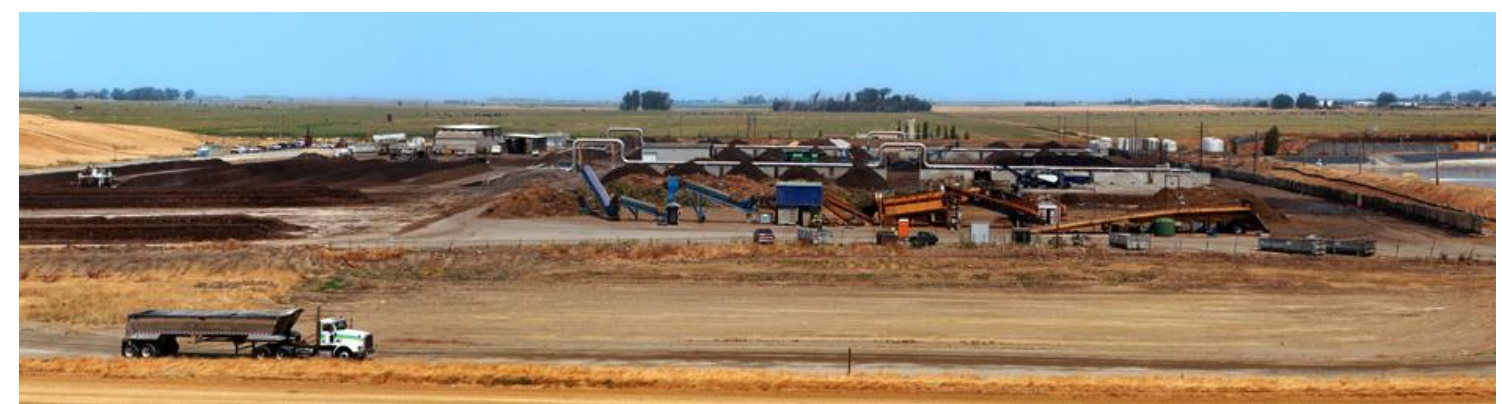

Fonte:http://thecompoststore.com/index.php/compost-facilities-old/jepson-prairie-organics, 2017. 
O composto curado serve de base para quatro produtos finais produzidos, os quais são misturados (Figura 26) com outros elementos (orgânicos e minerais) e comercializados pela Jepson, para diferentes clientes (RECOLOGY ORGANICS WASTE ZERO, 2016d):

- Composto Premium: produto rico em nutrientes feito a partir dos restos de alimentos e de materiais de poda. A demanda para este composto, em geral, são as vinícolas, agricultura orgânica e fruticultura. Este produto é certificado pelo Instituto de Materiais Orgânicos dos Estados Unidos;

- Super Composto Orgânico: é o Composto Premium misturado com casca de arroz, serragem, enxofre orgânico, gesso e farelo de pedra pome (Pumice). É usado principalmente como condicionar de solos, diretamente para plantio ou mistura de solo;

- Topsoil: é um composto que mistura o Composto Premium com casca de arroz, serragem, argila e gesso. É um produto para substituição e/ou preparação de solo, semeadura direta de pastagens e correção do solo;

- Ultra Mix Potting: é uma mistura do Composto Premium com casca de arroz, turfa, gesso, Groganics e pedra pode. É um produto pronto para o uso em qualquer tipo de plantio.

Figura 26 Tipos de produtos comercializados a partir da produção de composto da Jepson Prairie, 2016

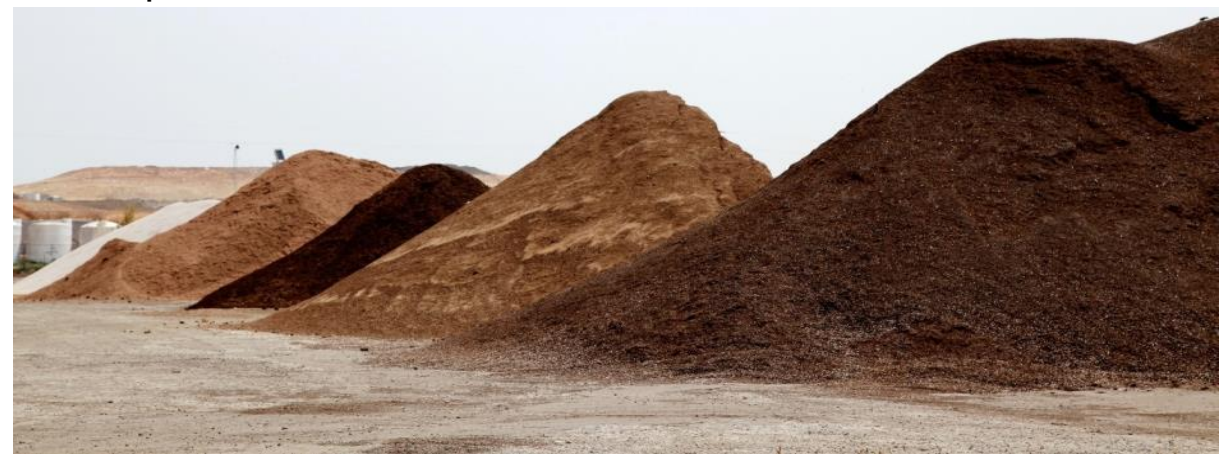

Fonte:http://thecompoststore.com/index.php/compost-facilities-old/jepson-prairieorganics., 2017 


\subsubsection{Recuperação de custos dos serviços de coleta de resíduos}

A viabilidade econômica da limpeza urbana em São Francisco é garantida por meio de cobrança de taxa de resíduos sólidos.

Todos os geradores de resíduos sólidos urbanos recebem a fatura (conta) por correio e podem processar o pagamento por meio de: débito em conta, cartão de crédito ou envio de cheque nominal a empresa RECOLOGY. O valor básico da taxa mensal para uma residência é de USD 15,00/mês, sendo que os geradores podem personalizar os tipos de serviços e tamanhos dos contentores, em função das quantidades e tipos de resíduos gerados. Os geradores considerados famílias de baixa renda têm direito a desconto de $25 \%$ no valor da taxa de resíduos.

\subsubsection{Programas de Minimização de Resíduos}

O programa "Lixo Zero" (Zero Waste) de São Francisco possui 19 subprogramas complementares que têm como objetivo dar o destino correto para os diversos tipos de resíduos que não são armazenados nos três contentores e visam reaproveitar e reutilizar diversos itens, de modo a complementar os serviços oferecidos pela coleta regular de resíduos sólidos urbanos. Os programas existentes estão apresentados no Quadro 15.

Quadro 15 Programas complementares de minimização de resíduos sólidos urbanos de São Francisco

\begin{tabular}{|l|l|}
\hline Subprogramas & \multicolumn{3}{|c|}{ Detalhamento } \\
$\begin{array}{l}\text { 1. Programa de } \\
\begin{array}{l}\text { Reutilização de } \\
\text { itens em bom } \\
\text { estado }\end{array}\end{array} \begin{array}{l}\text { Itens diversos em boas condições (estado geral e } \\
\text { funcionamento) que são entregues na Estação de } \\
\text { empreses. São separados e enviados para unidade de } \\
\text { reparo, onde são recondicionados e, posteriormente, } \\
\text { entregues às lojas de segunda mão para venda (Figura 28) }\end{array}$ \\
\hline $\begin{array}{l}\text { 2. Recicláveis } \\
\text { de lixeiras das } \\
\text { calçadas }\end{array}$ & $\begin{array}{l}\text { Coleta de materiais recicláveis das lixeiras das calçadas: } \\
\text { garrafas, latas, papel e plásticos rígidos (xícaras, cubas, } \\
\text { tampas, baldes e brinquedos sem fios ou peças metálicas) }\end{array}$ \\
\hline
\end{tabular}




\begin{tabular}{|c|c|}
\hline ab & etalhamento \\
\hline & $\begin{array}{l}\text { leta de materiais orgânicos de lixeiras de calçadas, tais } \\
\text { mo restos de alimentos, papel sujo, folhas, galhos e } \\
\text { antas para compostagem }\end{array}$ \\
\hline $\begin{array}{l}\text { 4. Reciclagem } \\
\text { de itens } \\
\text { volumosos }\end{array}$ & $\begin{array}{l}\text { leta especial para itens volı } \\
\text { etrodomésticos, sucata, madeira, } \\
\text { unícipes podem solicitar um veí } \\
\text { ns no website da Recology }\end{array}$ \\
\hline $\begin{array}{l}\text { 5. Reciclagem } \\
\text { de entulho de } \\
\text { construção e } \\
\text { demolição }\end{array}$ & $\begin{array}{l}\text { Coleta de entulho da construção civil (concreto, madeira, } \\
\text { metais, plásticos rígidos, papel e outros) a partir de } \\
\text { caçambas específicas colocadas nas obras que são } \\
\text { transportadas para triagem e posterior reciclagem em } \\
\text { unidade específica }\end{array}$ \\
\hline 7 & $\begin{array}{l}\text { Os colchões inutilizados são recolhidos por veículo } \\
\text { específico e enviados para a Estação de Transferência e } \\
\text { posteriormente para empresa local especializada na } \\
\text { reciclagem de colchões }\end{array}$ \\
\hline $\begin{array}{r}\text { de } \\
\text { aos }\end{array}$ & reis, \\
\hline $\begin{array}{l}\text { 8. } \\
\text { de }\end{array}$ & $\begin{array}{l}\text { Pontos de entrega para equipamentos eletrônicos (lâmpadas } \\
\text { fluorescentes, computadores, monitores, televisões e } \\
\text { outros). Os equipamentos eletrônicos são coletados e } \\
\text { transportados para a Estação de Transferência e } \\
\begin{array}{l}\text { posteriormente encaminhados para empresas } \\
\text { especializadas em reciclagem de resíduos eletrônicos } \\
\text { (Figura 27) }\end{array}\end{array}$ \\
\hline $\begin{array}{l}9 . \quad \text { Auto } \\
\text { Reciclagem }\end{array}$ & $\begin{array}{l}\text { oradores e pequenos empreiteiros descarregam na } \\
\text { stação de Transferência, resíduos de pequenas reformas } \\
\text { ou limpeza. Os resíduos recebidos são: madeira, metal, } \\
\text { npeza (embalagens de produtos químicos) }\end{array}$ \\
\hline $\begin{array}{l}\text { 10. Reciclas } \\
\text { de Bat }\end{array}$ & $\begin{array}{l}\text { s baterias de automóveis são coletadas e enviadas para } \\
\text { mpresas especializadas de reciclagem. Os moradores } \\
\text { eixam a bateria em sacos fechados em cima do contentor } \\
\text { reto e o coletor separa a bateria, que fica estocada na } \\
\text { stação de Transferência e depois é enviada para }\end{array}$ \\
\hline
\end{tabular}




\begin{tabular}{|c|c|}
\hline Subprogramas & Detalhamento \\
\hline & reciclagem \\
\hline $\begin{array}{l}\text { 11. Descarte } \\
\text { de } \quad \text { Produtos } \\
\text { Perigosos }\end{array}$ & $\begin{array}{l}\text { Os moradores podem levar para a Estação de Transferência, } \\
\text { seus resíduos perigosos (óleo de motor usado, restos de } \\
\text { tintas, solventes, produtos de limpeza, produtos químicos em } \\
\text { geral) ou agendar uma coleta específica. Estes produtos são } \\
\text { armazenados e posteriormente enviados para reutilização ou } \\
\text { reciclados (Figura 29) }\end{array}$ \\
\hline $\begin{array}{l}\text { 12. Reciclagem } \\
\text { para Grandes } \\
\text { Geradores }\end{array}$ & $\begin{array}{l}\text { O programa recebe resíduos (paletes, restos de madeira, } \\
\text { grandes peças de automóveis) que são enviados para } \\
\text { empresas de reciclagem }\end{array}$ \\
\hline $\begin{array}{l}\text { 13. Trituração } \\
\text { de materiais }\end{array}$ & $\begin{array}{l}\text { Reciclagem de concreto, tijolos, restos de asfalto de grandes } \\
\text { construções, reparos de rodovias, vias, entulho de } \\
\text { terremotos que ocorrem na Baia de São Francisco }\end{array}$ \\
\hline $\begin{array}{l}\text { 14. Reciclagem } \\
\text { e } \\
\text { Compostagem } \\
\text { de Resíduos de } \\
\text { Eventos } \\
\text { Especiais }\end{array}$ & $\begin{array}{l}\text { Programa específico para coleta e reciclagem de eventos } \\
\text { especiais tais como Parada do Ano Novo Chinês e Natal }\end{array}$ \\
\hline $\begin{array}{l}\text { 15. Reciclagem } \\
\text { de Pneus }\end{array}$ & $\begin{array}{l}\text { Os pneus usados são coletados separadamente, } \\
\text { armazenados na Estação de Transferência e posteriormente } \\
\text { enviados para empresa que tritura e recicla a borracha }\end{array}$ \\
\hline $\begin{array}{l}\text { 16. Centros } \\
\text { recuperação do } \\
\text { depósito de } \\
\text { embalagens }\end{array}$ & $\begin{array}{l}\text { Moradores pode reaver parte do valor pago pelas } \\
\text { embalagens (garrafas e latas) levando-as para locais de } \\
\text { recuperação do valor do depósito das embalagens }\end{array}$ \\
\hline $\begin{array}{l}\text { 17. Reciclagem } \\
\text { de Vidros de } \\
\text { Janela } \quad \text { e } \\
\text { vitrines }\end{array}$ & $\begin{array}{l}\text { Coleta específica para vidro de vitrines e janelas de clientes } \\
\text { comerciais que são coletados e enviados para reciclagem }\end{array}$ \\
\hline $\begin{array}{l}\text { 18. Reciclagem } \\
\text { de árvores de } \\
\text { Natal }\end{array}$ & $\begin{array}{l}\text { As árvores de natal são coletadas separadamente nas duas } \\
\text { primeiras semanas de janeiro e são desgalhadas e usadas } \\
\text { como combustível de caldeira para instalações de geração } \\
\text { de energia }\end{array}$ \\
\hline
\end{tabular}




\begin{tabular}{|c|c|}
\hline Subprogramas & Detalhamento \\
\hline $\begin{array}{ll}\text { 19. Pontos } & \text { de } \\
\text { entrega } & \text { de } \\
\text { isopor } & \\
\text { (styrofoam } & \\
\text { drop-off) } & \end{array}$ & $\begin{array}{l}\text { Moradores e empresas levam para os pontos de entrega } \\
\text { específicos, materiais de isopor. Todos os materiais } \\
\text { coletados também são enviados para a Estação de } \\
\text { Transferência e posteriormente são enviados para um } \\
\text { densificador especial que condensa pedaços soltos de } \\
\text { isopor em lingotes que são usados em placas de base e } \\
\text { molduras }\end{array}$ \\
\hline
\end{tabular}

Fonte: Recology San Francisco, 2016.

Figura 27 Local de recepção de Figura 28 Local de recepção de resíduos eletrônicos. Pier 96
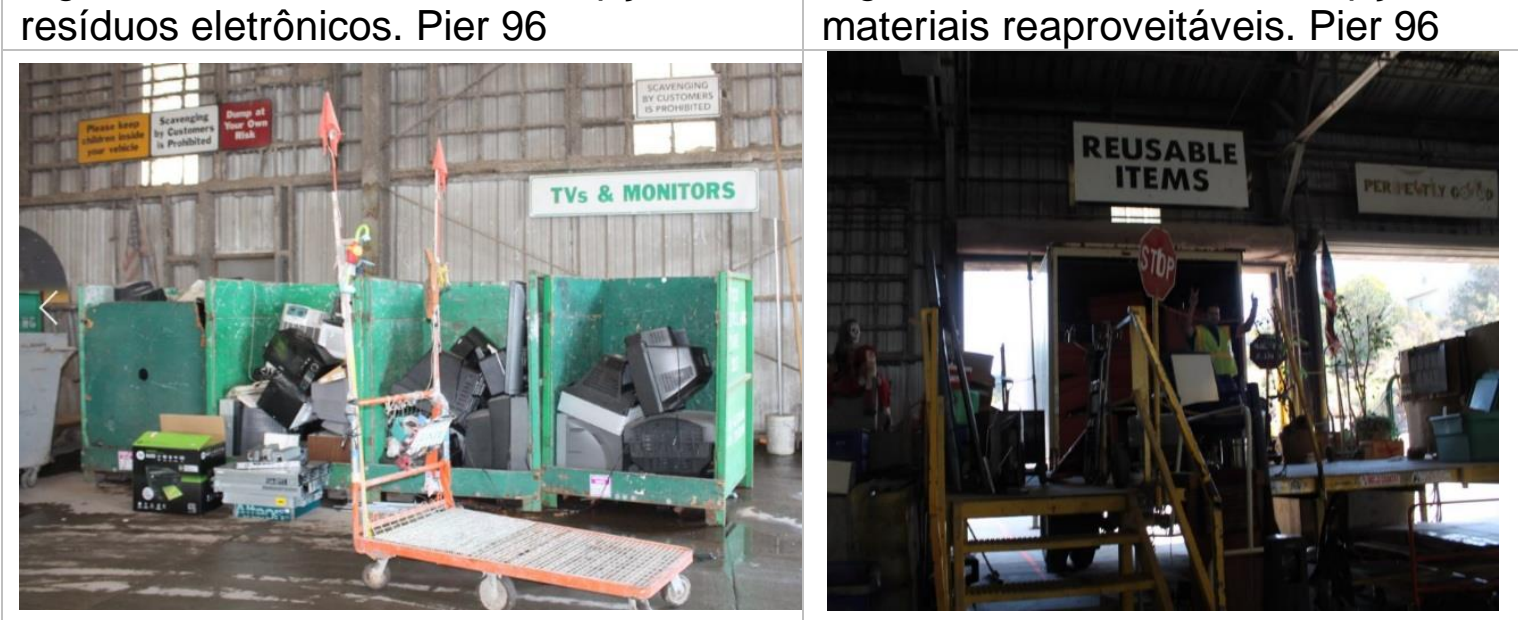

Fonte: levantamento de campo, 2014. Da autora.

Fonte: levantamento de campo, 2014. Da autora.

Figura 29 Local de entrega voluntária de embalagens com produtos químicos para pequenos geradores. Pier 96.

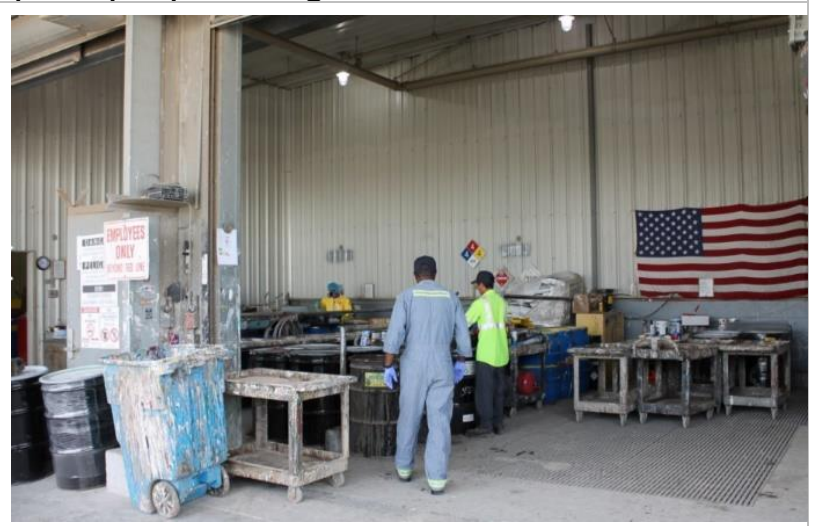

Fonte: levantamento de campo, 2014. Da autora. 


\subsubsection{Políticas Públicas Aplicadas aos Resíduos Sólidos em São Francisco}

São Francisco possui políticas públicas ambientais, cujo foco tem sido o combate ao aquecimento global, em diversas áreas (água, energia e transporte), além das políticas para a gestão dos resíduos sólidos urbanos, baseadas na reutilização e reciclagem completa dos resíduos produzidos na cidade.

A principal política pública na área de resíduos para diminuir o aquecimento global foi a eliminação dos aterros sanitários. Para tanto, os gestores da cidade criaram diversas ações com metas estabelecidas, planos e programas de gestão dos resíduos sólidos urbanos, que foram transformados em instrumentos legais.

As principais políticas públicas de São Francisco de resíduos sólidos urbanos foram formuladas e baseadas na necessidade do cumprimento da Política Estadual de Resíduos da Califórnia (AB n.ำ939/1989), que estabeleceu metas de eliminação do envio de resíduos sólidos para os aterros sanitários e executar a reutilização e reciclagem ao máximo, com metas para reduzir a quantidade de todos os resíduos sólidos gerados enviadas para aterros sanitários. Entretanto a cidade rapidamente ultrapassou a meta do governo estadual e estabeleceu suas próprias políticas que levaram a um dos melhores índices de reciclagem de resíduos sólidos urbanos dos Estados Unidos.

As políticas públicas de São Francisco para expandir a reutilização e a reciclagem de todos os resíduos sólidos gerados estão em conformidade com o estado da Califórnia. Para São Francisco cumprir as determinações da política estadual de resíduos sólidos, a partir do ano 2000, criou uma série de ações para serem executadas pela sociedade em geral e que foram transformadas em instrumentos legais, nos quais, o papel do poder público, da sociedade em geral, assim como, dos empresários foi claramente definido nas Portarias e Resoluções que foram sendo lançadas nos anos posteriores (Quadro 16). 
Quadro 16 Políticas públicas e seus instrumentos para a gestão dos resíduos sólidos em São Francisco, de 2002 a 2016

\begin{tabular}{|c|c|c|}
\hline Ano & $\begin{array}{l}\text { Número Instrumento } \\
\text { Legal }\end{array}$ & Política Pública \\
\hline 2002 & 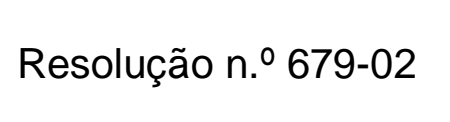 & $\begin{array}{l}\text { Determina a meta para desviar } 75 \% \text { dos } \\
\text { resíduos dos aterros }\end{array}$ \\
\hline 2003 & $\begin{array}{l}\text { Código de Meio } \\
\text { Ambiente }\end{array}$ & $\begin{array}{l}\text { Consolida as Portarias da cidade que regem a } \\
\text { proteção ao meio ambiente, aos recursos } \\
\text { naturais e a sustentabilidade que antes eram } \\
\text { tratados no Código Administrativo da cidade }\end{array}$ \\
\hline 2003 & $\begin{array}{l}\text { Resolução n.. 002-03- } \\
\text { COE }\end{array}$ & $\begin{array}{l}\text { Adota a data de } 2020 \text { para São Francisco } \\
\text { alcançar a meta de desviar } 100 \% \text { dos resíduos } \\
\text { dos aterros. Determina que o Departamento } \\
\text { de Meio Ambiente de São Francisco } \\
\text { desenvolva políticas e programas para } \\
\text { aumentar a responsabilidade dos produtores e } \\
\text { consumidores para alcançar a meta de não } \\
\text { dispor nenhuma quantidade de resíduos em } \\
\text { aterros }\end{array}$ \\
\hline 2005 & Portaria $n . .9115-05$ & $\begin{array}{l}\text { Requer um programa de compra } \\
\text { ambientalmente corretas para mercadorias } \\
\begin{array}{l}\text { compradas pela administração pública da } \\
\text { cidade }\end{array}\end{array}$ \\
\hline 2006 & Resolução n. $.94-06$ & $\begin{array}{l}\text { Responsabilidade Estendida do Produtor - } \\
\text { REP }\end{array}$ \\
\hline 2006 & Portaria 295-06 & $\begin{array}{l}\text { Alteração do Capítulo } 16 \text { do Código de Meio } \\
\text { Ambiente que estabeleceu a redução dos } \\
\text { resíduos do serviço de alimentação }\end{array}$ \\
\hline 2006 & $\begin{array}{l}\text { Diretiva Executiva 06- } \\
05\end{array}$ & Conservação dos Recursos e Reciclagem \\
\hline 2007 & 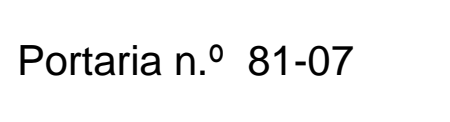 & $\begin{array}{l}\text { Alteração do Capítulo } 17 \text { do Código de Meio } \\
\text { Ambiente, redução das sacolas plásticas }\end{array}$ \\
\hline 2007 & 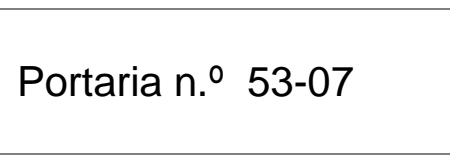 & $\begin{array}{l}\text { Requer materiais de conteúdo reciclado para } \\
\text { ser usado em obras públicas e projetos de } \\
\text { melhoria }\end{array}$ \\
\hline 2007 & $\begin{array}{l}\text { Diretiva Executiva 07- } \\
07\end{array}$ & $\begin{array}{l}\text { Proíbe os Departamentos da cidade de São } \\
\text { Francisco a utilizarem seus fundos públicos } \\
\text { para comprar água engarrafada }\end{array}$ \\
\hline
\end{tabular}




\begin{tabular}{|c|c|c|}
\hline Ano & $\begin{array}{c}\text { Número Instrumento } \\
\text { Legal }\end{array}$ & Política Pública \\
\hline 2008 & $\begin{array}{l}\text { Diretiva Executiva 08- } \\
02\end{array}$ & $\begin{array}{l}\text { Requer que os Departamentos Públicos de } \\
\text { São Francisco comprem papel } 100 \% \\
\text { reciclados e comprem produtos verdes } \\
\text { aprovados }\end{array}$ \\
\hline 2009 & Portaria n. $\stackrel{0}{100-09}$ & $\begin{array}{l}\text { Alterações nos Códigos de Meio Ambiente, } \\
\text { Capítulo } 19 \text {, de Obras Públicas seção } 173 \text { e } \\
\text { de Saúde, seções de } 291 \text { e } 293 \\
\begin{array}{l}\text { Obrigatoriedade da reciclagem e } \\
\text { compostagem }\end{array}\end{array}$ \\
\hline 2010 & $\begin{array}{l}\text { Resolução para Apoio } \\
\text { da Responsabilidade } \\
\text { Estendida do Produtor }\end{array}$ & $\begin{array}{l}\text { Resolução para Apoio da Responsabilidade } \\
\text { Estendida do Produtor - ERP }\end{array}$ \\
\hline 2010 & 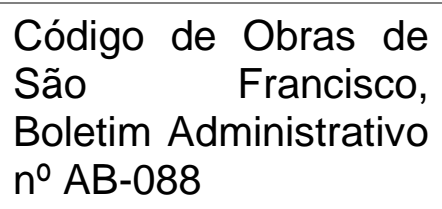 & $\begin{array}{l}\text { Especifica detalhes construtivos que os locais } \\
\text { de armazenamento de resíduos devem ter em } \\
\text { caso de novos projetos arquitetônicos e/ou } \\
\text { reformas }\end{array}$ \\
\hline 2012 & Portaria $n . \stackrel{0}{33-12}$ & $\begin{array}{l}\text { Código de Meio Ambiente: nenhum } \\
\text { estabelecimento de alimentos deve fornecer } \\
\text { sacolas plásticas aos clientes. Os } \\
\text { estabelecimentos que fornecerem devem } \\
\text { cobrar, pelo menos, dez centavos }(\$ 0,10) \text { por } \\
\text { sacola }\end{array}$ \\
\hline 2013 & $\begin{array}{l}\text { Resolução n. } .007- \\
13-\text { COE }\end{array}$ & $\begin{array}{l}\text { Apoio ao programa da Califórnia na } \\
\text { responsabilidade do produtor para reduzir a } \\
\text { presença de plástico no mar }\end{array}$ \\
\hline 2014 & Portaria $n . \stackrel{\circ}{28-14}$ & $\begin{array}{l}\text { Portaria que altera o Código de Meio Ambiente } \\
\text { da cidade para restringir a venda ou } \\
\text { distribuição de água potável em garrafas } \\
\text { plásticas de } 0,62 \text { litros ( } 21 \text { oz) ou menos; } \\
\text { definir a política da cidade para aumentar a } \\
\text { disponibilidade de água potável em áreas } \\
\text { públicas e barrar a utilização dos recursos } \\
\text { financeiros da administração da cidade para } \\
\text { comprar engarrafada água }\end{array}$ \\
\hline 2016 & Resolução n. ${ }^{\circ}$ 217-16 & $\begin{array}{l}\text { Todas as embalagens de bebidas } \\
\text { comercializadas na Califórnia que tenham um } \\
\text { único uso devem conter, no mínimo, } 25 \% \text { de } \\
\text { plástico reciclado }\end{array}$ \\
\hline
\end{tabular}




\begin{tabular}{|c|c|c|}
\hline Ano & $\begin{array}{c}\text { Número Instrumento } \\
\text { Legal }\end{array}$ & \multicolumn{1}{c|}{ Política Pública } \\
\hline 2016 & Portaria n.o 140-16 & $\begin{array}{l}\text { Proibe uso de diversos tipos de poliestireno } \\
\text { (isopor) para embalagens de alimentos e } \\
\text { determina o uso de materiais compostáveis ou } \\
\text { recicláveis }\end{array}$ \\
\hline
\end{tabular}

A Resolução n. $679-02$, de 30/09/2002 foi a primeira editada para o cumprimento das diretrizes do Conselho de Gerenciamento Integrado de Resíduos da Califórnia. O Conselho de Supervisores de São Francisco adotou como meta, para o ano de 2010 , desviar dos aterros $75 \%$ do total de resíduos sólidos gerados. Para isso, autorizou a Comissão de Meio Ambiente de São Francisco a adotar uma meta mais restritiva que a meta estadual: quando a cidade alcançasse a meta de não enviar $50 \%$ dos seus resíduos sólidos para aterros sanitários, poderia partir para a meta de aterro zero (COUNTY AND CITY OF SAN FRANCISCO, 2002).

Já em 6 de março de 2003, a Comissão de Meio Ambiente de São Francisco lançou a Resolução $n$. o 002-03-CE cuja meta para o ano de 2020 foi: não enviar nenhuma quantidade de resíduos sólidos para aterros sanitários. Esta meta ficou conhecida como "lixo zero" ou "Zero Waste". Nesta resolução, o Departamento de Meio Ambiente de São Francisco foi autorizado a desenvolver políticas públicas e programas para aumentar a responsabilidade dos produtores e dos consumidores (COUNTY AND CITY OF SAN FRANCISCO, 2003) em relação à separação dos resíduos na fonte geradora e, assim, enviálos para processos de reciclagem, ao invés do aterramento.

Dando sequência às ações de publicações de resoluções que definiram responsabilidades de produtores e consumidores, bem como, de redução da poluição ambiental e manutenção da saúde pública, a Comissão de Meio Ambiente de São Francisco, publicou em 2 de julho de 2006, a Resolução n.. 94-06 que estabeleceu a Responsabilidade Estendida do Produtor (REP) (COUNTY AND CITY OF SAN FRANCISCO, 2006a). Nesta Resolução, os resíduos sólidos declarados como "lixo universal", ou seja, resíduos domésticos 
em geral, que contém pilhas, lâmpadas fluorescentes ou tubos, termostatos e outros itens que contém mercúrio, chumbo, cádmio e outros produtos químicos, bem como, dispositivos eletrônicos incluindo videocassetes, microondas, telefones celulares e sem fio, impressoras e rádios foram associados à geração de impactos negativos significativos para a saúde e o meio ambiente, quando descartados de forma inadequada podendo causar contaminação do abastecimento de água (COUNTY AND CITY OF SAN FRANCISCO, 2006a).

Para corrigir estes impactos, a Resolução estabeleceu a responsabilidade estendida dos resíduos sólidos aos produtores para que as empresas assumissem a responsabilidade financeira e/ou física da gestão dos produtos pós consumo, de modo a fazer a reciclagem de seus produtos e providenciassem o descarte final adequado (COUNTY AND CITY OF SAN FRANCISCO, 2006a). Mencionou também que deveria ser incentivada a produção de bens e produtos mais duráveis, fáceis de reciclar, menos tóxicos e que o custo que o poder público teria com o descarte do "lixo universal" deveria ser transformado em incentivos aos produtores e distribuidores de produtos menos tóxicos (COUNTY AND CITY OF SAN FRANCISCO, 2006a).

Por fim, a Resolução estabeleceu que o Departamento de Meio Ambiente de São Francisco deveria desenvolver políticas públicas para a responsabilidade estendida do produtor, tais como, o sistema de "leasing" para todas as secretarias e departamentos públicos, para que os fabricantes, ao final do contrato e/ou vida útil do bem, seja responsável por coletar e reciclar o bem comercializado (COUNTY AND CITY OF SAN FRANCISCO, 2006a).

Ainda em 2006, a Comissão de Meio Ambiente de São Francisco publicou a Portaria Ordinária n.ำ 295-06 (n.ํ 060944) em 29 de novembro que alterou o Código Ambiental de São Francisco. Esta portaria estabeleceu a proibição do uso de poliestireno nas embalagens e utensílios descartáveis para alimentos nos restaurantes, fornecedores de alimentos e prestadores de serviço do ramo e determinou a substituição por materiais biodegradáveis e/ou 
compostáveis ou reciclados, a menos que não houvesse uma alternativa viável. Nesta portaria também foi proibido o uso de embalagens de alimentos e utensílios de plástico com clorofluorcarbonetos e foram previstas sanções para violação do que foi estabelecido (COUNTY AND CITY OF SAN FRANCISCO, 2006b).

No ano seguinte, em 22 de março de 2007 foi realizada uma emenda no Código de Meio Ambiente de São Francisco que obrigou o uso de plástico biodegradável e papel reciclável para as sacolas distribuídas nos estabelecimentos comerciais para armazenamento e transporte dos produtos. Também obrigou a exibição dos dizeres "reciclável" e "reutilizável" nas sacolas e estabeleceu penalidades para o descumprimento desta determinação, onde na primeira infração, a multa não deveria ultrapassar USD 100,00, na segunda infração não ultrapassar USD 200,00 e na terceira infração, não ultrapassar USD 500,00.

Com esta alteração no Código de Meio Ambiente, São Francisco foi a primeira cidade nos Estados Unidos a restringir o uso de sacolas plásticas não biodegradável, bem como, exigiu que as sacolas utilizadas fossem fabricadas com plástico mais espesso, de modo que permitissem a reutilização. Dois anos depois dessa proibição foi editada uma emenda (Portaria n.ํ 100-09), muito completa em termos de ações para o gerenciamento dos resíduos sólidos que alterou diversos capítulos de três códigos municipais: (i) Código de Meio Ambiente, Capítulo 19, seções de 1901 a 1912; (ii) Código de Serviços Públicos, seção 173; (iii) Código de Saúde, seções de 291 e 293. Esta Portaria estabeleceu a obrigatoriedade da segregação dos resíduos sólidos em três categorias: recicláveis (azul), compostáveis (verde) e rejeito (preto). Os munícipes que não executassem a separação dos resíduos seriam punidos, conforme previsto em seção específica do Código de Meio Ambiente.

Os munícipes deveriam pagar pela coleta de resíduos sólidos para a empresa de limpeza pública, como um serviço público. Os gestores (síndicos, 
zeladores, gerentes) de condomínios residenciais e comerciais deveriam providenciar capacitação para os moradores, funcionários e contratados para fazerem a separação dos resíduos e fornecer contentores adequados para as quantidades geradas de resíduos, com identificações claras e objetivas dos tipos de resíduos que cada contentor deve receber e, ainda, garantir local e posicionamento adequado para que os usuários pudessem depositar seus resíduos de forma adequada. Os gestores também ficaram responsáveis por garantir capacitação para novos inquilinos, moradores, funcionários e contratados, pelo menos, uma vez por ano (COUNTY AND CITY OF SAN FRANCISCO, 2009). As edificações novas ou reformas de prédios residenciais e comerciais deveriam garantir espaço adequado para os três tipos de contentores.

Os proprietários e gestores de estabelecimentos que vendem alimentos para serem consumidos no local (restaurantes, lanchonetes, mercearias, bares e similares) e organizadores de eventos foram obrigados a fazer a separação dos resíduos sólidos e garantir quantidade de contentor adequada à geração dos resíduos e local e treinamento para seus funcionários. Também foram obrigados a manter, pelo menos, 1 contentor de cada tipo de resíduo dentro do estabelecimento, próximos à entrada e/ou saída. Este tipo de estabelecimento não teve permissão para dispor óleo e/ou gordura nos contentores pretos (COUNTY AND CITY OF SAN FRANCISCO, 2009).

As responsabilidades das empresas de coleta de resíduos, segundo esta Resolução, ficaram responsáveis por fornecer à todos os estabelecimentos residenciais, comerciais e de serviços, contentores adequados (tamanho, cor, identificação e nome da empresa) para acondicionar os resíduos separados (COUNTY AND CITY OF SAN FRANCISCO, 2009).

Durante o serviço de coleta contenerizada, o operador da empresa de limpeza que verificar que o contentor contem resíduos inadequados conforme a normativa de separação (recicláveis, compostáveis e rejeito), deveria, 
obrigatoriamente, deixar uma etiqueta identificando que o resíduo estava armazenado no contentor errado. Se o erro persistisse, o operador deveria, novamente, deixar outra etiqueta de identificação do erro e enviar carta, notificando o responsável pela gestão dos resíduos. Se o erro ocorrer pela terceira vez, o operador da limpeza deveria deixar o contentor cheio e não recolher os resíduos. E, se na próxima coleta, se o contentor não estivesse vazio, o operador da limpeza pública deixaria nova etiqueta no contentor e enviaria uma carta para o responsável pela gestão dos resíduos naquela edificação, identificando quais foram os materiais depositados em contentor errado e quais são as ações que o gerador deveria tomar para que os resíduos fossem recolhidos na próxima coleta (COUNTY AND CITY OF SAN FRANCISCO, 2009).

O operador da limpeza pública passou a ser o responsável por enviar uma lista como nomes dos responsáveis e respectivos endereços das edificações que não corrigiram os erros de separação dos resíduos ao diretor do Departamento de Meio Ambiente que tem por responsabilidade, analisar o caso e aplicar penalidades previstas (multas, interdições e outros) (COUNTY AND CITY OF SAN FRANCISCO, 2009).

Segundo o Código de Meio Ambiente de São Francisco, mesmo que uma instalação de tratamento e/ou disposição final seja operada por empresas privadas, nenhuma pessoa física ou jurídica pode enviar resíduos sólidos para estas unidades, a não ser que estejam autorizadas (contrato) pela direção do Departamento de Meio Ambiente (COUNTY AND CITY OF SAN FRANCISCO, 2009).

O Departamento de Meio Ambiente, segundo o Código de Meio Ambiente, é o responsável por fazer todos os avisos públicos, audiências, dar diretrizes e formular regulamentos para que a separação dos resíduos sólidos na fonte geradora ocorra conforme previsto. O Departamento deve, inclusive, providenciar toda a assistência aos demais órgãos públicos, para que as 
regulamentações da gestão dos resíduos sólidos sejam cumpridas e, manter, no seu website, todas as informações necessárias sobre os tipos de resíduos adequados para cada tipo de contentor (COUNTY AND CITY OF SAN FRANCISCO, 2009).

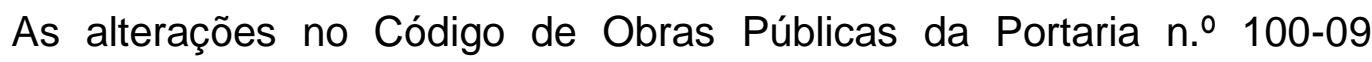
referiram-se à necessidade dos cidadãos, empresas, corporações, mercearias, lojas de bebidas, estabelecimentos que vendem alimentos para consumo imediato, manterem três contentores (azul, verde e preto) para o uso dos clientes. Estes também devem ter capacidade adequada, estarem identificados corretamente e serem limpos no final do dia. O não cumprimento desta obrigatoriedade acarreta, ao residente ou gestor do estabelecimento, multa de USD 80,00 a USD 100,00 na primeira violação e nas reincidências, multas entre USD 150,00 a USD 200,00 e USD 250,00 a USD 500,00, respectivamente.

As alterações no Código de Saúde da Portaria n. 100-09 foram realizadas para todos os subitens da Seção 291 tornarem-se adequadas ao Capítulo 16 do Código de Meio Ambiente, já mencionadas e também para a Seção 293, que estabeleceu como violação do Código, a retirada de resíduos sólidos dos contentores (COUNTY AND CITY OF SAN FRANCISCO, 2010b).

Para complementar 0 ciclo de medidas legais que reforçam 0 comprometimento da administração pública de São Francisco, o Conselho de Supervisores publicou a Resolução n. ${ }^{100}$ 10.475/2010 que estabeleceu o apoio a Responsabilidade Estendida do Produtor (REP). Nesta resolução, foi estabelecido que os fabricantes são os responsáveis por projetar, produzir e gerenciar todo o ciclo de vida de seu produto (end-of-life systems) e que devem incorporar no preço final dos produtos, os custos de recuperação, reciclagem e disposição final e, assim, retirar o custo que era arcado indiretamente pelo poder público municipal, uma vez que a maioria dos produtos acabavam em um dos três contentores da coleta regular (COUNTY AND CITY OF SAN FRANCISCO, 2010b). 
A Resolução n. 100.475/2010 encorajou os fabricantes a produzirem produtos que têm maior durabilidade, são facilmente consertados em caso de defeito, que podem ser reutilizados e/ou reciclados e ainda, que sejam menos tóxicos ao meio ambiente.

Para dar sustentabilidade aos princípios da resolução, o prefeito da cidade enviou cartas para diversas associações estaduais para que todas apoiassem a formação de um quadro legislativo e regulamentar para o sucesso da REP com ações articuladas junto a diversas associações correlatas: Conselho Estadual de Produtores da Califórnia, Liga Nacional das Cidades da Califórnia, Associação dos Municípios da Califórnia, Associação de Resíduos Sólidos da América do Norte, Associação de Gerenciamento de Resíduos Sólidos Estadual, Departamento de Controle de Substâncias Menos Tóxicas.

Para complementar a Portaria $n . .9100-09$ que gerou alterações no Código de Obras de São Francisco, em 2010 foi aprovado o Boletim Administrativo $(A B)$ n.․ 088, que apresentou todos os detalhes construtivos que os locais de armazenamento e coleta de resíduos sólidos recicláveis, compostáveis e lixo devem ter em novos projetos arquitetônicos e/ou ampliações. Em linhas gerais, os locais de armazenamento e coleta devem: ser projetados para armazenar todos os resíduos gerados nas três categorias (recicláveis, compostáveis e lixo); estar integrados, no projeto arquitetônico, com a vegetação e com a topografia do local; estar de acordo com as leis federais e estaduais e também com outros instrumentos legais locais, tais como normas do Corpo de Bombeiros, Transporte, Segurança e Acessibilidade; estar protegidos de chuva; serem acessíveis a pessoas com deficiências físicas; não gerarem impactos ambientais, como barulho, odor, atração de vetores; serem acessíveis aos tipos de equipamentos e veículos que farão a coleta; preveem rotas e áreas de manobras para os veículos de coleta (COUNTY AND CITY OF SAN FRANCISCO, 2010b). 
No ano de 2012, o Departamento de Meio Ambiente de São Francisco publicou emenda ao Código de Meio Ambiente, por meio da Portaria n.ํ 33-12 (02/07/12), que determinou a cobrança de dez centavos por sacolas plásticas que o consumidor solicite no momento de suas compras, em todos os tipos de estabelecimentos comerciais e de serviços da cidade, complementando assim a portaria de 2007 que havia estabelecido a obrigatoriedade de papel reciclado e/ou plástico biodegradável para confecção das sacolas. Esta Portaria também atribuiu, ao Departamento de Meio Ambiente, a responsabilidade de executar todas as ações de sensibilização e educação para os estabelecimentos comerciais, de serviços e seus funcionários e consumidores, a usar sacolas reutilizáveis (COUNTY AND CITY OF SAN FRANCISCO, 2012c).

Em 2014, o Departamento de Meio Ambiente de São Francisco publicou a Portaria n.ำ 28-14 que restringiu a venda ou distribuição da água potável em garrafas plásticas de 0,62 litros ou menos, a fim de desestimular a geração dos resíduos e criou ainda, a obrigatoriedade do governo municipal de aumentar a disponibilidade de água potável em áreas públicas e barrar a utilização dos recursos financeiros da cidade para comprar água engarrafada (COUNTY AND CITY OF SAN FRANCISCO, 2014).

Já em 2016, por meio da Resolução $n$. 217-16, todas as embalagens de bebidas comercializadas na Califórnia, que tenham um único uso, foram obrigadas a conter, no mínimo, $25 \%$ de plástico reciclado. E, a Portaria $\mathrm{n} .{ }^{\circ} 140$ 16 proibiu o uso de diversos tipos de poliestireno (isopor) para embalagens de alimentos e determinou que as embalagens fossem produzidas com materiais compostáveis ou recicláveis (COUNTY AND CITY OF SAN FRANCISCO, 2016). 


\subsection{CIDADE DO CABO}

A Cidade do Cabo situa-se no extremo sul do continente africano, na província do Cabo Ocidental (Western Cape). Possui uma área de $2.445 \mathrm{~km}^{2} \mathrm{e}$ faz divisas com Distrito da Costa Oeste ao norte, Cape Winelands District a leste e Overberg District ao sudeste, conforme apresentado na Figura 30. É a segunda maior cidade da África do Sul em termos populacionais, abrigando um dos mais importantes Portos do continente, além de ser a capital legislativa da República da África do Sul.

Figura 30 Localização geral da Cidade do Cabo na África do Sul

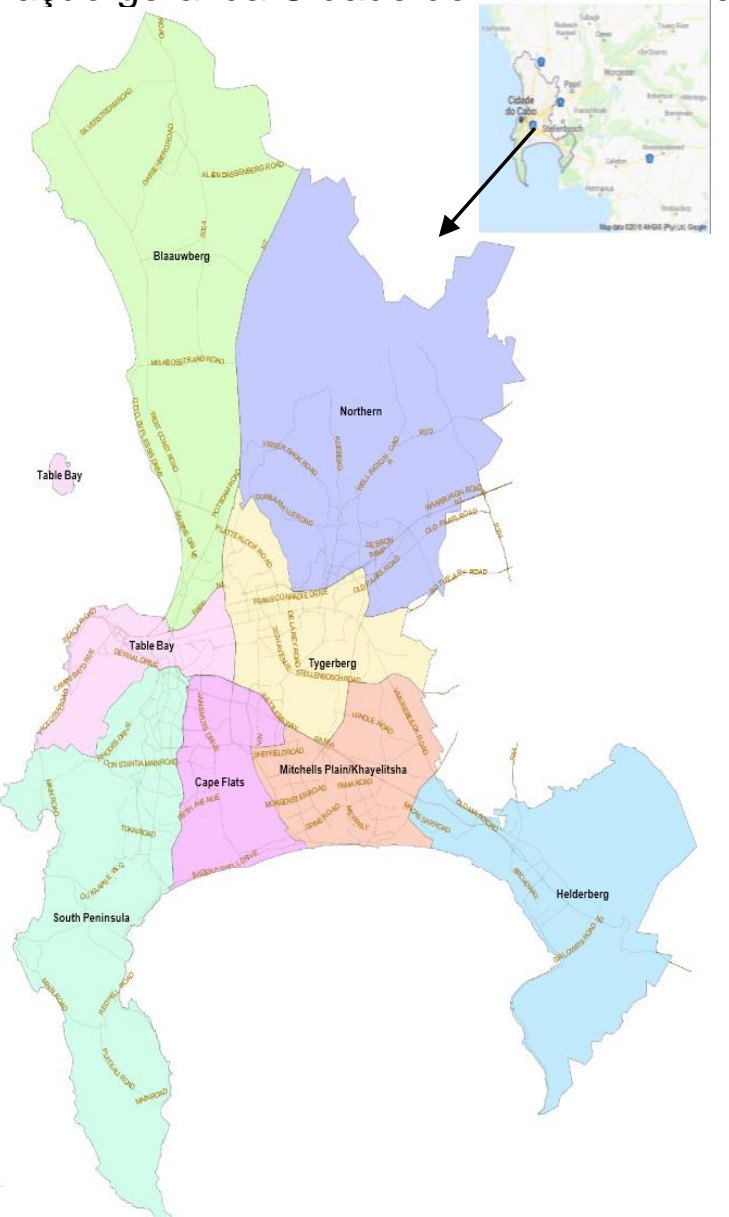

Fonte: Google Earth Pro. Strategic Information Strategic Development Information \& GIS August 2013. 
Figura 31 Vista geral da Cidade do Cabo na África do Sul

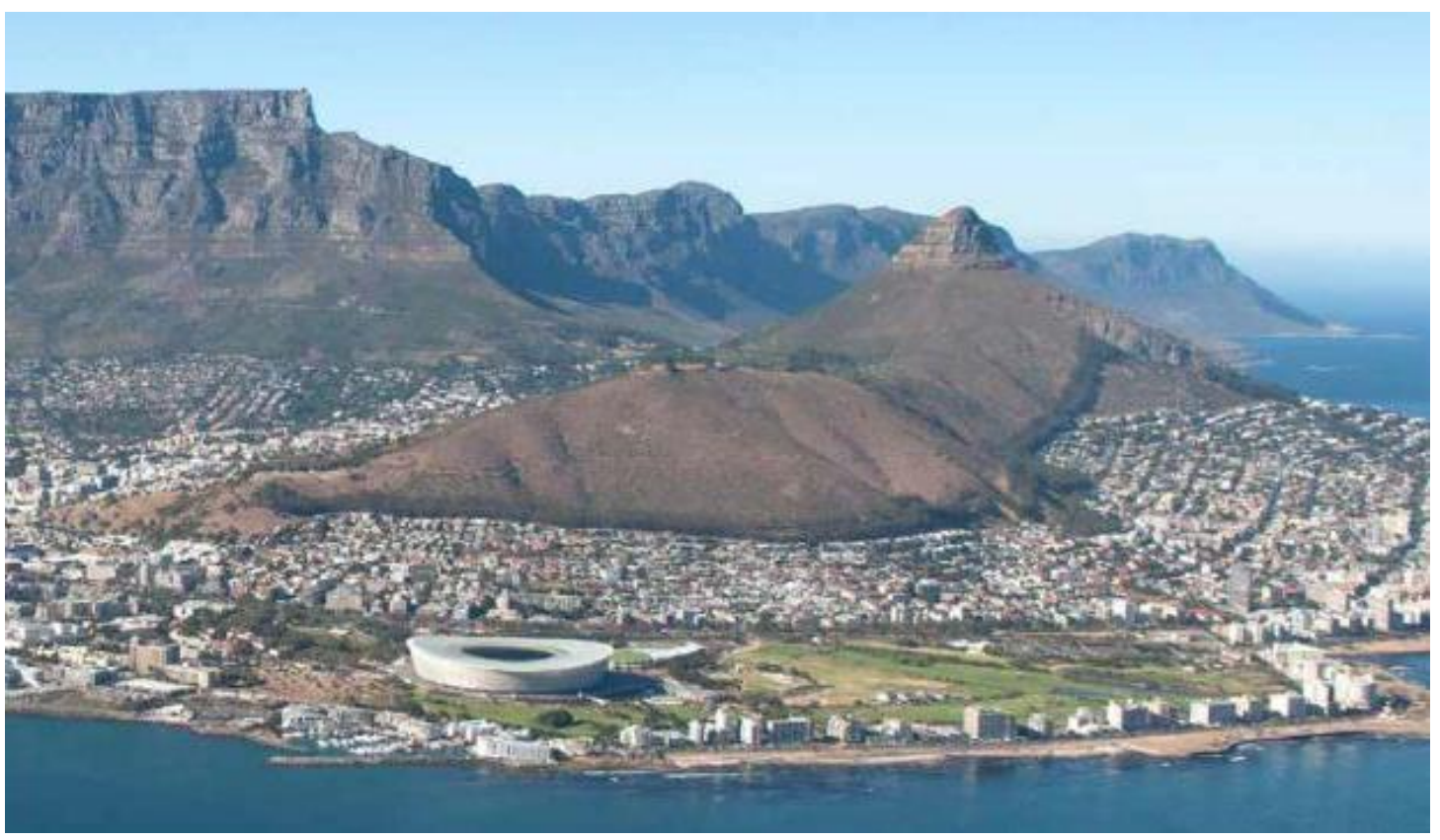

Fonte: ANNUAL REPORT City Of Cape Town 2015/16.

Em 1997, após o fim do apartheid, a região da Cidade do Cabo que era formada por 39 municípios foi restruturada em 7 regiões para tratar os temas de serviços municipais, entretanto em dezembro de 2000 , os municípios foram unificados formando a "The City of Cape Town".

A Cidade do Cabo é a mais antiga da África do Sul e o mais importante destino turístico no continente africano, ocupando destaque em termos econômicos na província, sendo conhecida pelos sul-africanos como "A Cidade Mãe", com uma população total estimada em 2016, de 4 milhões de habitantes (Tabela 13).

Tabela 13 Caracterização da Cidade do Cabo nos anos de 2011 e 2016

\begin{tabular}{l|r|r}
\hline \multirow{2}{*}{ Item } & \multicolumn{2}{|c}{ Ano } \\
\cline { 2 - 3 } & $\mathbf{2 0 1 1}$ & \multicolumn{1}{c}{$\mathbf{2 0 1 6}$} \\
\hline População total & $3.740 .026(2)$ & $4004793(1)$ \\
\hline Número de habitações & $1.068 .573(1)$ & $1264849(1)$ \\
\hline Renda familiar média ano (dólares) & $13.003,38(3)$ & $\ldots$ \\
\hline Densidade demográfica (hab/km²) & $1.530(2)$ & $\ldots$ \\
\hline
\end{tabular}


Fonte: (1) Socio economic profile City of Cape Town, 2016. (2) http://www.statssa.gov.za/?page_id=1021\&id=city-of-cape-town-municipality (3) Census 2011 Municipal report, Western Cape, Report 03-01-49

Nota: (...) Dado não disponível

A maioria dos residentes da Cidade do Cabo falam outras línguas (72\%) e o inglês era falado somente por 27\% da população total, em 2004 (Quadro 17).

Quadro 17 Variáveis demográficas da Cidade do Cabo, em 2011

\begin{tabular}{|l|r|}
\hline Variáveis & \multicolumn{1}{c|}{$\mathbf{2 0 1 1}$} \\
\hline Número total de famílias & $1.068 .572(1)$ \\
\hline $\begin{array}{l}\text { Número médio de pessoas por família } \\
\text { Porcentagem total das famílias que falam outra língua } \\
\text { em casa, além do inglês (línguas: Afrikaans, isiXhosa e } \\
\text { outras) (\%) }\end{array}$ & $\begin{array}{r}72 \% \text { em } 2004 \\
(2)\end{array}$ \\
\hline $\begin{array}{l}\text { Porcentagem da população de } 5 \text { a } 24 \text { anos que } \\
\text { frequenta escola 2011 (\%) }\end{array}$ & 67,8 (3) \\
\hline $\begin{array}{l}\text { Fonte: (1) https://www.westerncape.gov.za/assets/departments/treasury/Documents/Socio- } \\
\text { economic-profiles/2016/City-of-Cape-Town/city_of_cape_town_2016_socio- } \\
\text { economic_profile_sep-lg.pdf. (2) http://www.statssa.gov.za/publications/Report-00-91-01/Report- } \\
\text { 00-91-012004.pdf. (3) Census 2011 Municipal report, Western Cape, Report 03-01-49 }\end{array}$
\end{tabular}

\subsubsection{História e Reciclagem na Cidade do Cabo}

Segundo Benson \& Vanqa-Mgijima (2010), a África do Sul possui:

(...) uma longa história de pessoas que coletam lixo nas ruas para sobreviver. Durante a era do apartheid, os locais de despejo de resíduos eram frequentemente localizados perto de favelas e aldeias rurais. Os resíduos eram recolhidos em grande parte de áreas dos brancos e despejado em favelas (área dos negros), onde apresentava um perigo para a saúde das comunidades que viviam nos entornos. Mesmo assim, os desempregados e pobres examinavam os lixões para obter restos de comida para consumo e obter garrafas para vender

Benson \& Vanqa-Mgijima (2010) também apontaram que na Cidade do Cabo, nas décadas de 1970 e 1980, os resíduos sólidos eram coletados nas áreas ocupadas por famílias brancas da classe média, duas vezes por semana. A coleta era realizada pelos trabalhadores da Câmara Municipal e os resíduos transportados para os locais de triagem na Estação de Transferência Athlone, onde os materiais recicláveis eram classificados e separados para comercialização e os não recicláveis, enviados para lixões do município. 
Ainda segundo os autores, desde a "adoção das políticas neoliberais por várias administrações sulafricanas, a escala da recuperação privada aumentou, assim como a disponibilidade de pessoas pobres para fazer parte da cadeia de recuperação, por pelo menos três razões" (BENSON \& VANQA-MGIJIMA, 2010: 2):

- Os serviços públicos de limpeza foram reduzidos para minimização de custos para atender às restrições fiscais e favorecer as empresas privadas;

- Grandes empresas têm buscado a redução dos custos de produção a partir do uso de materiais recuperados, especialmente com o uso de papel, madeira e outros, bem como, para atender à legislação que exige o uso de mais materiais reciclados;

- A falta de empregos formais expulsou os trabalhadores para a busca de outras formas de obtenção de renda.

Outro aspecto apontado por Benson \& Vanqa-Mgijima é que o aumento da recuperação de resíduos sólidos recicláveis na Cidade do Cabo esteve diretamente ligado à necessidade da população se organizar coletivamente de

diferentes formas para contestar a opressão vivida durante décadas com a política do apartheid.

Segundo Ferrara et al. (2008) a Cidade do Cabo iniciou o gerenciamento dos resíduos sólidos na década de 1980 de maneira tímida e mais recentemente (anos 2000), se tornou uma cidade líder no tema, com uma política integrada de gerenciamento de resíduos sólidos.

\subsubsection{Gerenciamento dos Resíduos Sólidos Urbanos na Cidade do Cabo}

O Departamento de Resíduos Sólidos da administração municipal é responsável pelo gerenciamento dos resíduos sólidos urbanos gerados na Cidade do Cabo. 
A coleta de resíduos sólidos urbanos domiciliares é realizada uma vez por semana sendo gerenciada de maneira diferente entre bairros formais e informais (assentamentos), sendo estes, equivalentes a $18 \%$ do total dos domicílios (WESTERN CAPE GOVERNAMENT, 2017).

Todos residentes dos bairros formais da Cidade do Cabo são responsáveis por solicitar, junto ao Departamento de Resíduos Sólidos, um contentor (lixeira) de 240 litros de capacidade, onde devem armazenar seus resíduos até o dia da coleta (Figura 32). Os contentores possuem um sistema de rádio frequência que permite que o Departamento conheça a localização exata do equipamento, bem como, quantas vezes foi descarregado nos caminhões de coleta.

Figura 32: contentor preto para resíduos do Programa Think Twice que são enviados para aterros sanitários

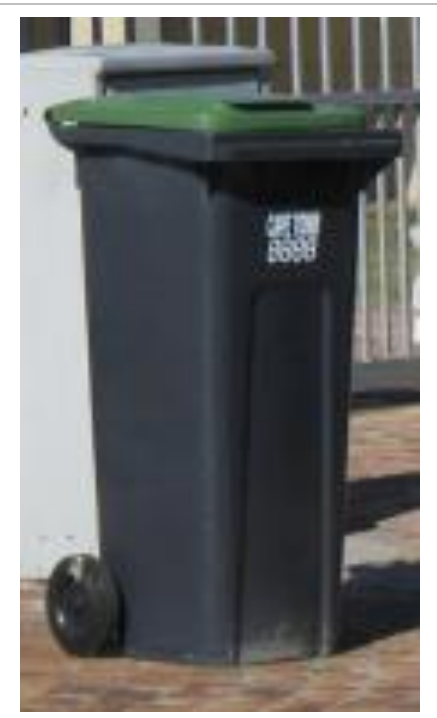

Fonte: levantamento de campo, 2018. Da autora

A coleta de resíduos sólidos urbanos é realizada diretamente pelo Departamento de Resíduos Sólidos ou seus contratados (empresas do setor de resíduos sólidos de grande porte e empresas locais menores que atuam nas comunidades). 
Para o ano de 2017 foi estimada a geração de 2,5 milhões de toneladas sendo que $27 \%$ deste total foi desviado dos aterros sanitários, a partir da soma total de todos os programas de minimização de resíduos sólidos urbanos, calculado em relação ao total de resíduos sólidos coletados (Tabela 14). Cabe ressaltar que os valores para as taxas de resíduos reciclados foram informações obtidas durante o levantamento de campo junto ao Departamento responsável.

Tabela 14 Quantidades de resíduos sólidos urbanos coletados na Cidade do Cabo, por tipo, entre 2007 e 2016

\begin{tabular}{|c|c|c|c|c|c|c|c|}
\hline \multirow[b]{2}{*}{ Ano } & \multicolumn{6}{|c|}{ Resíduos Sólidos Urbanos (t) } & \multirow[b]{2}{*}{$\begin{array}{c}\% \\
\text { Reciclado/ } \\
\text { Total }\end{array}$} \\
\hline & Geral & $\begin{array}{c}\text { Perigoso } \\
\text { S }\end{array}$ & $\begin{array}{l}\text { Entulho e } \\
\text { Inertes }\end{array}$ & Podas & $\begin{array}{l}\text { Programas } \\
\text { Minimização } \\
\text { De Resíduos }\end{array}$ & Total & \\
\hline 2006 & $\ldots$ & $\cdots$ & $\cdots$ & 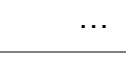 & $\cdots$ & $\ldots$ & $\cdots$ \\
\hline $\begin{array}{c}2007 \\
(1)\end{array}$ & $\cdots$ & $\cdots$ & $\cdots$ & $\cdots$ & $\cdots$ & 2.712 .805 & $\cdots$ \\
\hline $\begin{array}{c}2008 \\
(1)\end{array}$ & $\cdots$ & $\cdots$ & $\cdots$ & $\cdots$ & $\cdots$ & 1.997 .156 & $\cdots$ \\
\hline $\begin{array}{c}2009 \\
(1)\end{array}$ & $\ldots$ & $\ldots$ & $\cdots$ & $\ldots$ & $\ldots$ & 1.813 .713 & $\cdots$ \\
\hline $\begin{array}{c}2010 \\
(1)\end{array}$ & $\cdots$ & $\ldots$ & $\cdots$ & $\ldots$ & $\ldots$ & 1.813 .713 & $\cdots$ \\
\hline $\begin{array}{c}2011 \\
(2)\end{array}$ & 1.279 .124 & 41.397 & 317.220 & 60.822 & 183.404 & 1.881 .967 & $10 \%$ \\
\hline $\begin{array}{c}2012 \\
(2)\end{array}$ & 1.250 .843 & 43.001 & 310.358 & 90.578 & 280.474 & 1.975 .254 & $14 \%$ \\
\hline $\begin{array}{l}2013 \\
(2)\end{array}$ & 1.640 .503 & 24.249 & 365.794 & 96.382 & 218.805 & 2.345 .733 & $9 \%$ \\
\hline $\begin{array}{c}2014 \\
(2)\end{array}$ & 1.615 .315 & 21.004 & 603.263 & 41.378 & 190.472 & $2,471,432$ & $8 \%$ \\
\hline $\begin{array}{c}2015 \\
(2)\end{array}$ & 1.190 .482 & 19.774 & 811.333 & 10.450 & 356.217 & 2.388 .256 & $15 \%$ \\
\hline $\begin{array}{c}2016 \\
(3)\end{array}$ & $\ldots$ & $\cdots$ & $\ldots$ & $\ldots$ & $\ldots$ & $2,537.483$ & $27 \%$ \\
\hline
\end{tabular}

Fonte: (1) 3rd Generation IWM Plan, 2016. (2) Western Cape Integrated Waste Management Plan 20172022, 2016. (3) Levantamento de campo, 2018.

Nota: (...) Dado não disponível.

A composição gravimétrica dos resíduos sólidos urbanos da Cidade do Cabo em 2011 foi a seguinte: 20\% de resíduos orgânicos, 39\% de resíduos recicláveis, $22 \%$ de inertes, $9 \%$ de perigosos e $10 \%$ de outros resíduos. Especificamente para os resíduos sólidos domiciliares, estes representam 45\% do total dos resíduos sólidos gerados (Tabela 15), cuja composição 
gravimétrica foi a seguinte: $11 \%$ de orgânicos (restos de alimentos e poda), $21 \%$ de recicláveis (resíduos secos :embalagens e papel), $10 \%$ de outros materiais e $3 \%$ de resíduos perigosos.

Tabela 15 Composição gravimétrica dos resíduos sólidos urbanos recebidos nos aterros da Cidade do Cabo, em 2011

\begin{tabular}{lc}
\hline \multicolumn{1}{c}{ Resíduos Sólidos Urbanos } & Porcentagem (\%) \\
\hline Orgânicos Poda enviada direto para aterro & 2 \\
\hline Orgânicos de Parques/jardins & 0 \\
\hline Outros - Perigosos & 6 \\
\hline Outros - Orgânicos & 7 \\
\hline Outros - Recicláveis & 18 \\
\hline Inertes - Entulho & 22 \\
\hline Domiciliar - Orgânicos (poda) & 6 \\
\hline Domiciliar - Resíduos Perigosos & 3 \\
\hline Domiciliar - Embalagens & 15 \\
\hline Domiciliar - Papel & 6 \\
\hline Domiciliar - Restos de alimentos & 5 \\
\hline Domiciliar - Outros & 10 \\
\hline Total & $\mathbf{1 0 0}$ \\
\hline
\end{tabular}

Fonte: Levantamento de campo, 2018

As unidades de recepção, tratamento e/ou destinação final da Cidade do Cabo estão apresentadas na Tabela 16 apresentada a seguir.

Tabela 16 Unidades de recepção, tratamento e/ou disposição final da Cidade do Cabo, por tipo de resíduos, em 2018

\begin{tabular}{|c|c|c|}
\hline Unidade & Quantidade & Resíduos Recebidos \\
\hline Drop off sites & 19 & \multirow{4}{*}{$\begin{array}{c}\text { poda de jardins de domicílios, } \\
\text { poda das áreas verdes e } \\
\text { parques }\end{array}$} \\
\hline $\begin{array}{l}\text { Drop off sites anexos aos } \\
\text { aterros ou estações de } \\
\text { transbordo }\end{array}$ & 7 & \\
\hline Drop off Athlone & 1 & \\
\hline Sub Total & 27 & \\
\hline Aterro Sanitário Bellville South & 1 & \multirow{4}{*}{$\begin{array}{l}\text { todos os resíduos sólidos } \\
\text { urbanos com exceção dos } \\
\text { perigosos, rejeitos }\end{array}$} \\
\hline Aterro Sanitário Coastal Park & 1 & \\
\hline Aterro Sanitário Vissershok & 1 & \\
\hline Sub Total & 3 & \\
\hline Estação de Transbordo & 1 & Os resíduos gerais dos \\
\hline
\end{tabular}




\begin{tabular}{|c|c|c|}
\hline \begin{tabular}{l}
\multicolumn{1}{c}{ Unidade } \\
Swartklip Refuse Transfer \\
Station (SRTS)
\end{tabular} & Quantidade & $\begin{array}{c}\text { Resíduos Recebidos } \\
\text { distritos de Mitchells Plain e } \\
\text { Khayelitsha }\end{array}$ \\
\hline Sub Total & 1 & \\
\hline $\begin{array}{l}\text { Unidade de } \\
\text { Recuperação/Separação de } \\
\text { Materiais (MRF) - Kraaifontein } \\
\text { integrated waste management } \\
\text { facility }\end{array}$ & 1 & Resíduos domiciliares secos \\
\hline Sub Total & 1 & \\
\hline $\begin{array}{l}\text { Unidade de Compostagem - } \\
\text { Bellville }\end{array}$ & 1 & poda triturada dos drop offs \\
\hline $\begin{array}{l}\text { Unidade de Compostagem - } \\
\text { Reliance }\end{array}$ & 1 & poda triturada dos drop offs \\
\hline Sub Total & 2 & \\
\hline TOTAL & 34 & \\
\hline
\end{tabular}

Fonte: Levantamento de campo, 2018

Todas as unidades (Tabela 16) foram implantadas pela administração municipal com exceção da Unidade de Compostagem da Reliance pois, segundo a constituição nacional da República da África do Sul, esta é uma responsabilidade dos municípios. Somente as operações são terceirizadas para empresas contratadas pela administração municipal.

Devido à existência de um percentual relativo alto de resíduos orgânicos provenientes de podas de jardim (6\%) entregues pelos moradores nos Drop Offs existentes na cidade, o Departamento de Resíduos Sólidos implantou uma unidade de compostagem em Bellville e terceirizou os serviços de outra unidade para a empresa Reliance. Com esta estratégia, a Cidade do Cabo possui em seu processo de tratamento de resíduos sólidos orgânicos, unidades de compostagem que produzem composto para diversos usos, que são comercializados para as vinícolas da região para produção de vinho orgânicos, viveiros, produtores de hortaliças, dentre outros.

O fluxograma da origem e destino dos resíduos sólidos urbanos domiciliares está apresentado na Figura 33. 
Figura 33 Fluxograma da origem e destino dos resíduos sólidos urbanos domiciliares da Cidade do Cabo, 2018

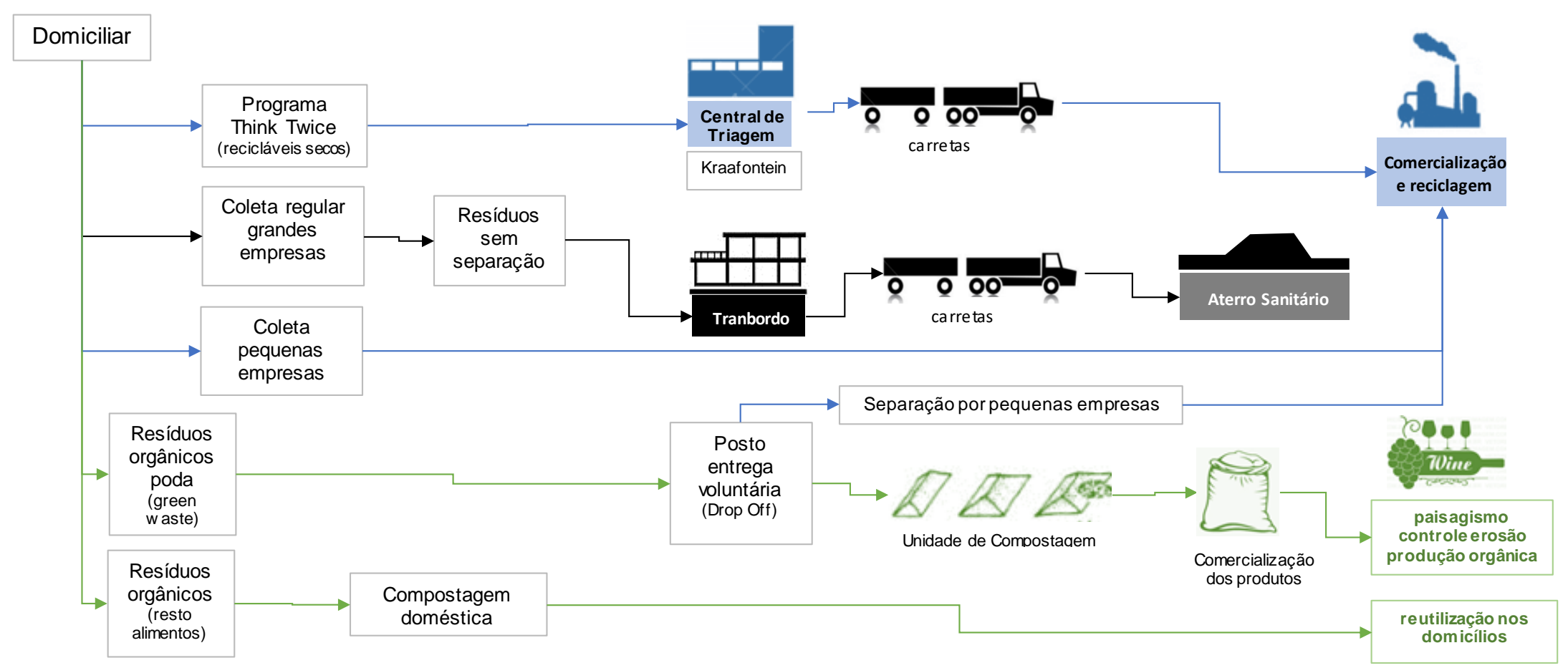

Elaboração: a autora 


\subsubsection{Recuperação de custos dos serviços de coleta de resíduos}

$\mathrm{Na}$ Cidade do Cabo, os residentes pagam uma tarifa mensal para os serviços de coleta de resíduos sólidos domiciliares. Um contentor de resíduos de 240 litros por semana gera uma tarifa mensal de cerca de USD 10,00. Segundo informações obtidas em entrevista, a relação de "pague pelo que joga" (pay-as-you-trow) é uma maneira muito adequada do poder público arrecadar constantemente os recursos necessários para pagamento dos serviços prestados à população.

A tarifa dos serviços de coleta é atualizada anualmente e o munícipe pode requerer mais de um contentor, bastando efetuar uma solicitação no endereço eletrônico da administração municipal e processar o pagamento.

\subsubsection{Programas de Minimização de Resíduos da Cidade do Cabo}

Segundo informações obtidas em entrevista com o responsável do setor de Minimização de Resíduos do Departamento de Resíduos Sólidos da Cidade do Cabo, pelo menos, $30 \%$ de toda a população efetua algum tipo de separação de resíduos e entrega seus resíduos para programas de reciclagem formais (empresas cadastradas na administração municipal) ou para outras iniciativas existentes na cidade, tais como: escolas, Organizações Não Governamentais (ONGs) e outros. O setor de minimização ainda não possui dados quantitativos destas iniciativas.

Além da segregação dos resíduos na fonte geradora, a Cidade do Cabo possui diversos programas complementares para desviar os resíduos do aterramento. Os programas existentes estão descritos resumidamente a seguir.

- Programa Think Twice de coleta de materiais recicláveis

Parte da cidade é abrangida pelo programa Think Twice (Pense Duas Vezes) que é a coleta de resíduos sólidos secos ou recicláveis (papel, plástico, 
papelão, vidros, latas e metais em geral) de domicílios e estabelecimentos comerciais em geral. Os participantes do programa recebem um contentor (preto) para armazenar resíduos que são enviados para aterros e contentores e/ou sacos limpos para estocagem de materiais recicláveis.

Este programa foi iniciado em 2001 como projeto piloto na região de Marina da Gama e posteriormente expandido para a região de Atlantic em 2007 e, em 2011, para a região de Kraaifontein.

Os serviços do programa Think Twice são realizados por empresas privadas contratadas (grandes e pequenas empresas/small business (Figura 34) pela administração pública municipal em vários bairros, conforme apresentado no Quadro 18 e na Figura 35. As empresas recebem pelos serviços e podem comercializar os resíduos recicláveis coletados ou transportálos para a Unidade de Recuperação/Separação de Materiais (MRF) Kraaifontein.

Quadro 18 Bairros de Cidade do Cabo abrangidos pelo Programa Think Twice.

\begin{tabular}{|l|l|l|l|}
\hline \multicolumn{1}{|c|}{$\begin{array}{c}\text { Bairros } \\
\text { Abrangidos }\end{array}$} & \multicolumn{1}{c|}{$\begin{array}{c}\text { Empresa } \\
\text { Abrangidos }\end{array}$} & \multicolumn{1}{|c|}{ Empresas } \\
\hline Gordon's Bay & Wasteplan & Pinelands & Wasteplan \\
\hline Strand & Wasteplan & Parklands & Wasteplan \\
\hline Somerset West & Wasteplan & Melkbosstrand & Wasteplan \\
\hline Macassar & Wasteplan & Bloubergstrand & Wasteplan \\
\hline Hout Bay & Wasteplan & Sea Point & Salt River Recycling \\
\hline Camp's Bay & Wasteplan & Green Point & Mandla Recycling \\
\hline Fresnaye & Wasteplan & Mouille Point & Mandla Recycling \\
\hline Bantry Bay & Wasteplan & Three Anchor Bay & Mandla Recycling \\
\hline Clifton & Wasteplan & - & - \\
\hline
\end{tabular}

$\mathrm{Na}$ época da implantação deste programa, o critério de seleção de regiões foi aleatório, isto é, não foram realizados estudos que determinassem regiões com maior potencial de coleta de resíduos recicláveis secos. Este programa foi uma forma de atrair as empresas privadas para coletarem os recicláveis e comercializá-los, pois as empresas que prestavam serviços para a 
administração municipal para a coleta regular de resíduos não possuíam caminhões suficientes para expandir os setores de coleta, além daqueles contratados inicialmente.

Nas regiões não atendidas pelo programa, os geradores de resíduos domiciliares podem descartar seus recicláveis nos drop offs existentes na cidade.

Figura 34 Pequenas empresas cadastradas no Departamento de Resíduos Sólidos da Cidade do Cabo que executam a coleta e triagem de recicláveis do Programa Think Twice

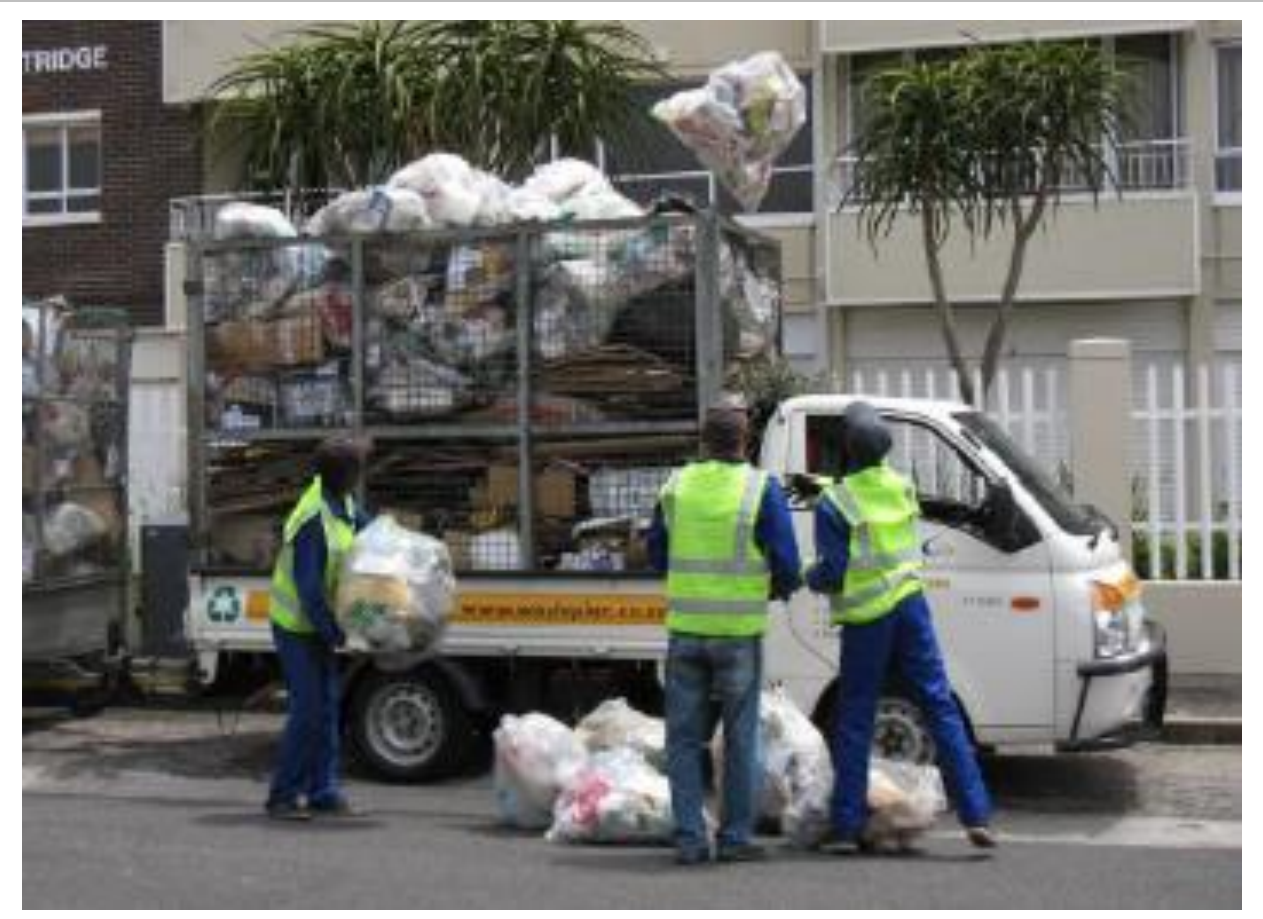

Fonte: levantamento de campo, 2018. Da autora 
Figura 35 Regiões abrangidas pelo Programa Think Twice e Drof Offs da Cidade do Cabo, 2018

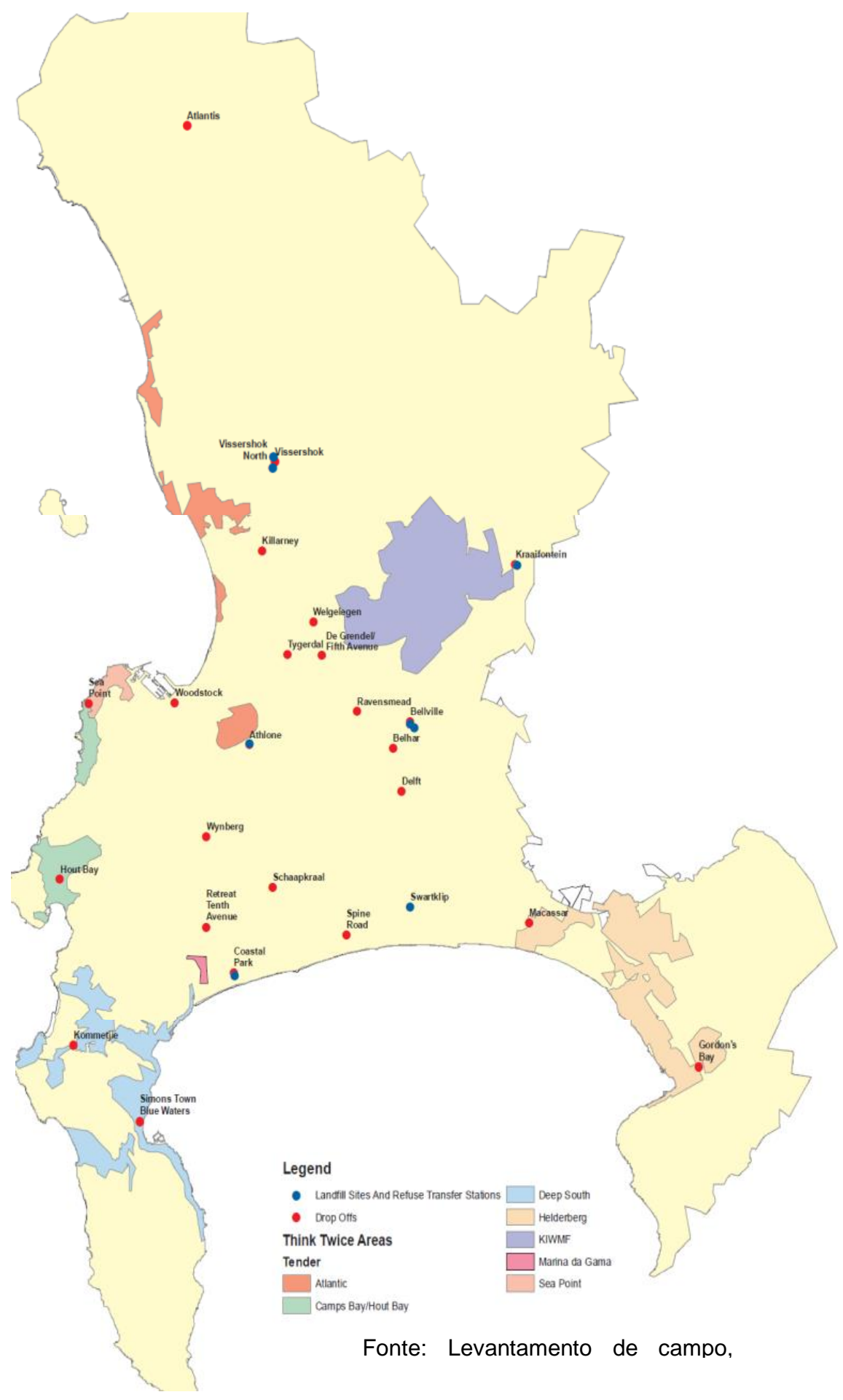


- Drop Off ou Pontos de Entrega Voluntária

Os resíduos sólidos domiciliares recicláveis e restos de materiais orgânicos provenientes de podas de jardins podem ser transportados e descarregados pelos geradores nos 27 Drop Offs existentes na cidade (Figura 35), onde a quantidade permitida para descarte é $1.500 \mathrm{~kg}$ por dia, por gerador. É permitido que os geradores descartem também: resíduos eletrônicos, entulhos de pequenas reformas, objetos volumosos, óleos lubrificantes usados (único resíduo perigoso aceito), dentre outros.

A instalação dos Drop Offs foi definida a partir de zonas de abrangência (buffers) com raio de $7 \mathrm{~km}$, de modo que todo o território possa ser abrangido por um drop off a cada $7 \mathrm{~km}$.

Os resíduos orgânicos provenientes de podas são triturados e enviados para unidades de compostagem, sendo este processo realizado por empresas privadas conveniadas com a administração municipal.

Os resíduos domiciliares recicláveis (resíduos secos) dos Drop Offs são armazenados separadamente e triados por pequenas empresas privadas que, após manifestarem interesse nos resíduos e, efetivarem cadastro formal no Departamento de Resíduos Sólidos, podem retirá-los para comercialização própria. Cabe destacar que estas pequenas empresas, segundo informações obtidas, são empresas de um único indivíduo que possui seu próprio caminhão e que, geralmente, contrata diariamente, ajudantes para os serviços de triagem de materiais. Pagam ao Departamento de Resíduos Sólidos uma taxa mensal equivalente a 8 USD/mês e podem retirar gratuitamente os resíduos com potencial de comercialização junto a indústria de reaproveitamento $\mathrm{e}$ reciclagem, não recebendo nenhum subsidio do Departamento de Resíduos Sólidos.

Ainda segundo informações obtidas, as pequenas empresas que estão habilitadas para recuperar os resíduos de Drop Offs de áreas com maior renda familiar conseguem obter melhores receitas com a comercialização dos 
materiais e em contrapartida, aquelas que atuam em áreas cuja renda familiar é menor, tem permissão para triar materiais em mais de uma unidade, bem como, fazer a coleta domiciliar de materiais recicláveis em algumas regiões.

Os entulhos recebidos nos Drop Offs são enviados para reprocessamento e posterior e reutilização. Os resíduos que não são recicláveis ou não tem aproveitamento são transportados para os aterros sanitários.

A operação de todos os Drop Offs é realizada pela equipe do Departamento de Resíduos Sólidos.

Durante as pesquisas de campo foram visitadas duas unidades de Drop Offs (Kraaifontein e Muizenberg) cuja documentação fotográfica a seguir, ilustra parte das etapas descritas (Figura 36 a Figura 42).

Figura 36 Rampas de acesso para Figura $\mathbf{3 7}$ Entrega de materiais descarga de materiais recicláveis. recicláveis. Kraaifontein Drop Off. Kraaifontein Drop Off.

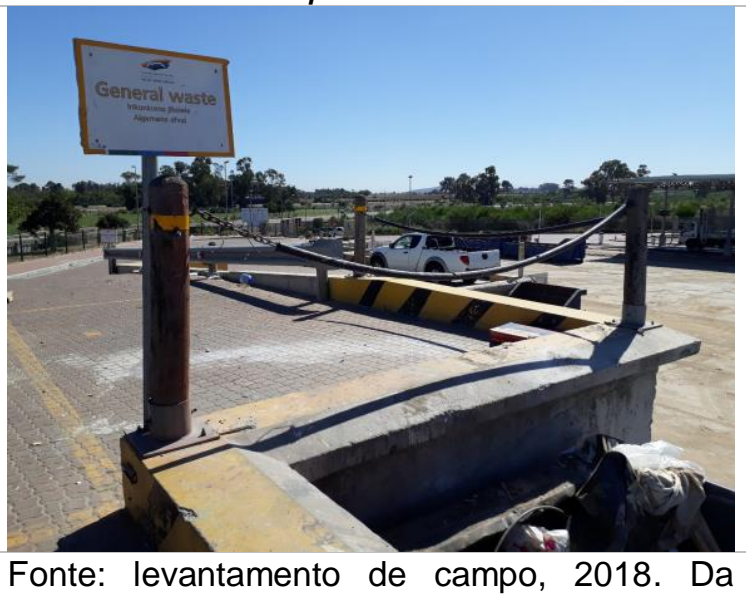
Rampas

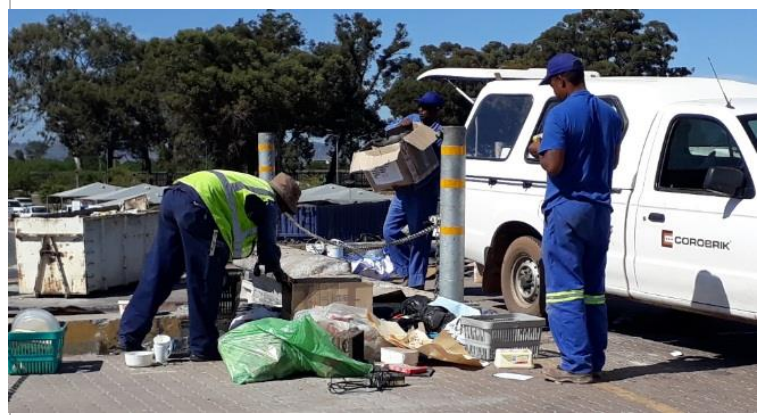

Fonte: levantamento de campo, 2018. Da autora 
Figura 38 Contentor para recepção de óleos lubrificantes usados. Muizenberg Drop Off.

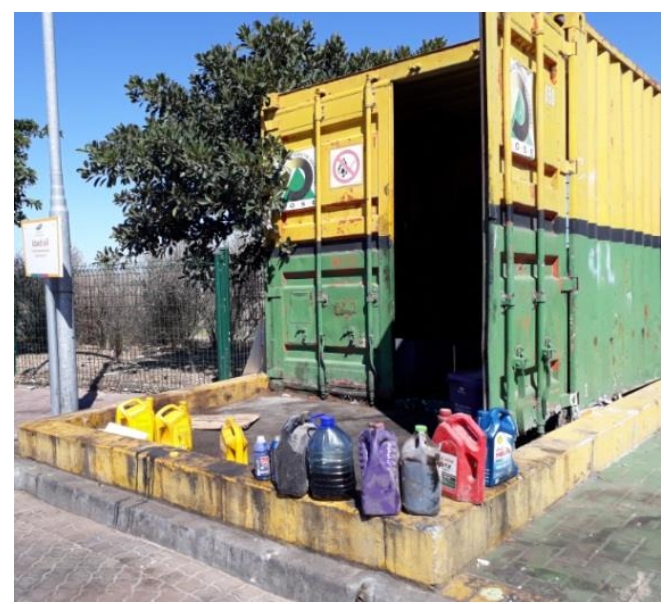

Fonte: levantamento de campo, 2018. Da autora
Figura 39 Baias para armazenagem de resíduo eletrônico. Kraaifontein Drop Off.

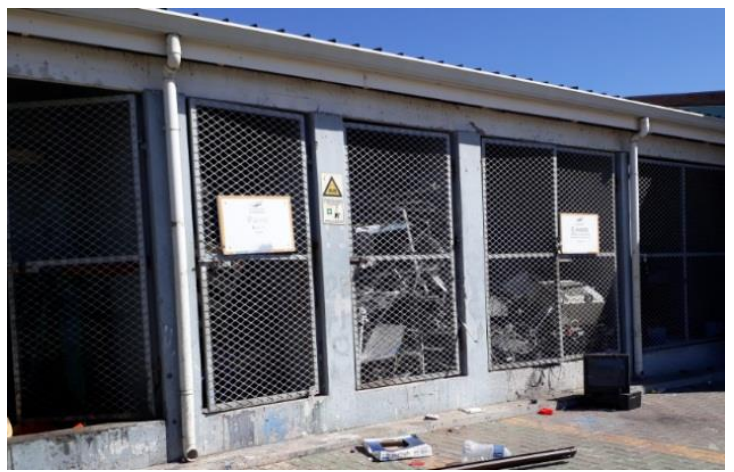

Fonte: levantamento de campo, 2018. Da autora
Figura 40 Área de carregamento de poda para futuro transporte para unidade de compostagem. Muizenberg Drop Off

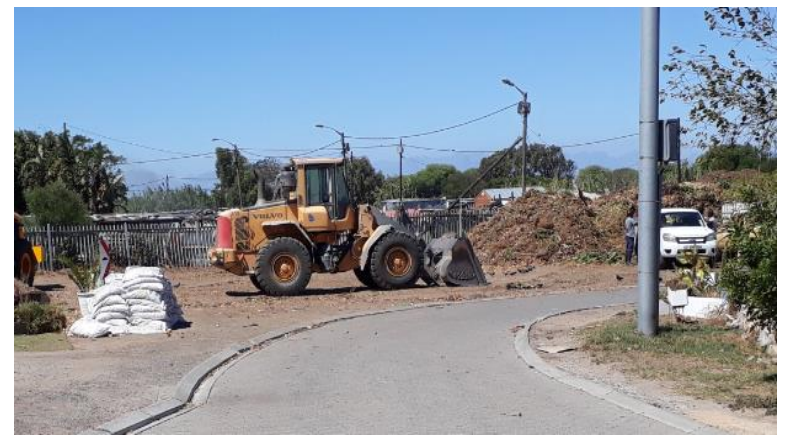

Fonte: levantamento de campo, 2018. Da autora
Figura 41 Escritório de empresa Reliance que comercializa o composto proveniente da compostagem de poda. Muizenberg Drop Off

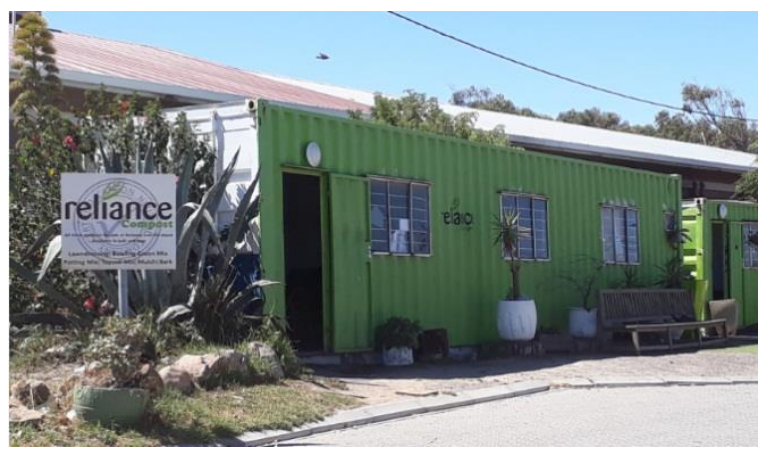

Fonte: levantamento de campo, 2018. Da autora 
Figura 42 Caminhão de empresa de pequeno porte que tria e comercializa os materiais recicláveis entregues pelos munícipes no Drop Off de Muizenberg

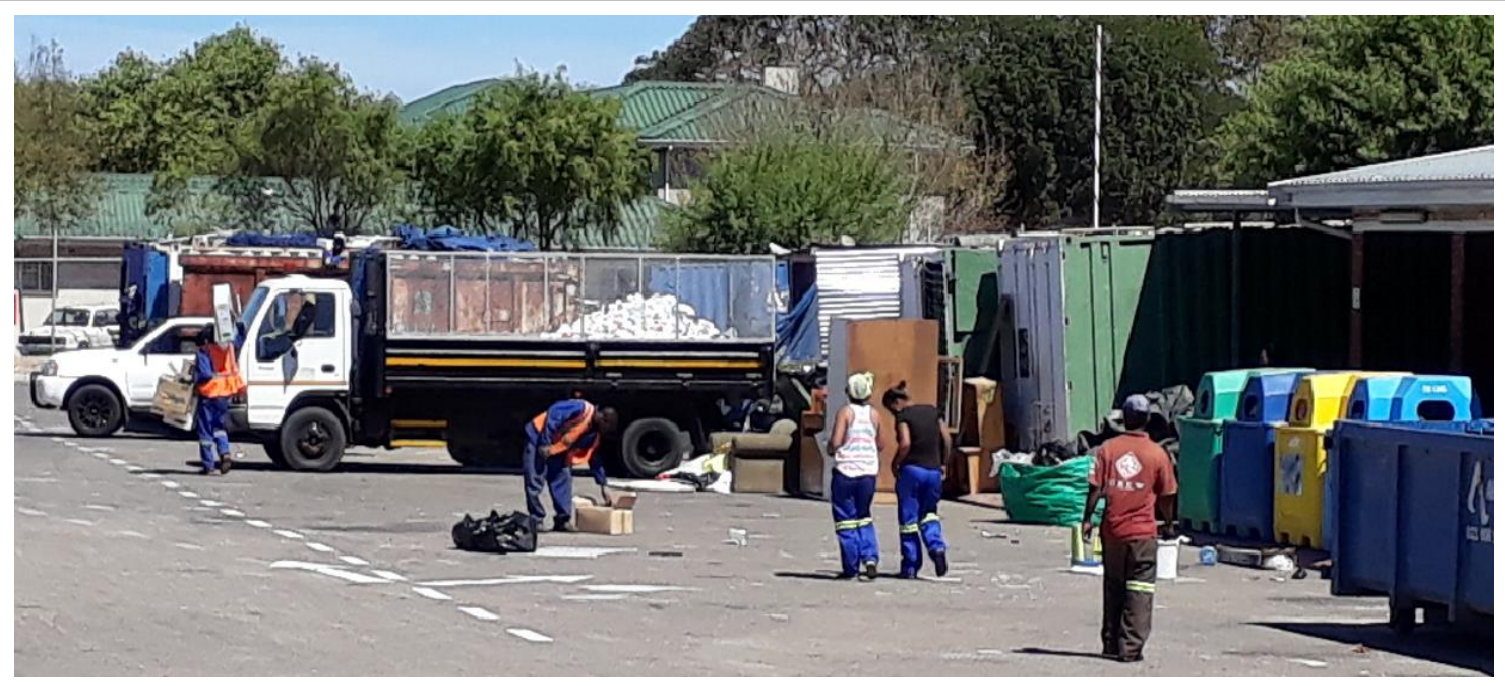

Fonte: levantamento de campo, 2018. Da autora

- Compostagem Domiciliar

A fim de diminuir as quantidades de resíduos orgânicos domiciliares provenientes de restos de alimentos na Cidade do Cabo, o Departamento de Resíduos Sólidos implantou um projeto piloto com a doação de composteiras caseiras (Home Composting), o qual teve iniciou em 2012 com 25 participantes (Figura 43). O Departamento de Resíduos estima que cerca de 20 quilos de resíduos orgânicos provenientes de restos de alimentos são desviados dos aterros sanitários por mês para cada composteira caseira.

Posteriormente foi implantado um estudo de viabilidade entre 2013 e 2014, quando 700 residências situadas em áreas de renda familiar baixa e média receberam as composteiras caseiras.

O programa foi um sucesso segundo informações obtida na pesquisa de campo devido a: (i) o retorno nas mídias sociais e correios eletrônicos dos participantes do programa foi acima das expectativas (Figura 44); (ii) "Os participantes estavam felizes por participar do programa, especialmente pessoas idosas. O programa envolveu também segurança alimentar e 
jardinagem". Em função do retorno positivo, o programa foi expandido: na fase 1/2016 foram distribuídas 5.693 unidades; na fase 2/2017 foram distribuídas 5.097 unidades; na fase 3/2017 foram distribuídas 1.196 unidades; e em 2018 estão previstas distribuições de mais composteiras caseiras.

Figura 43 Modelo de composteira Figura 44 Fotografia enviada ao caseira distribuída gratuitamente Departamento de Resíduos Sólidos por pela administração municipal da participante do Programa que utiliza o Cidade de Cabo. composto em sua propriedade

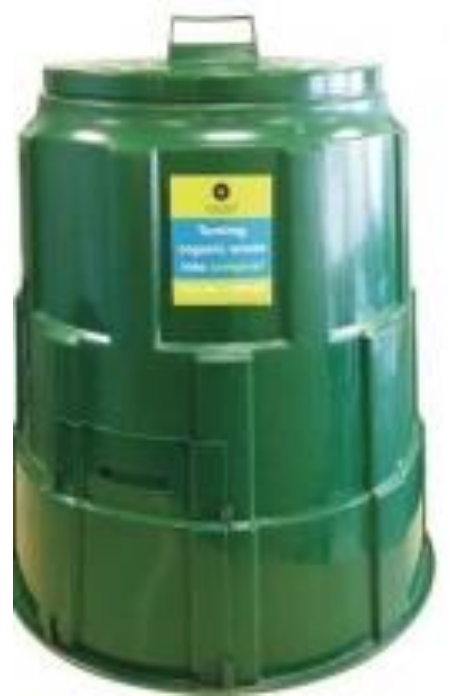

Fonte: levantamento de campo, 2018

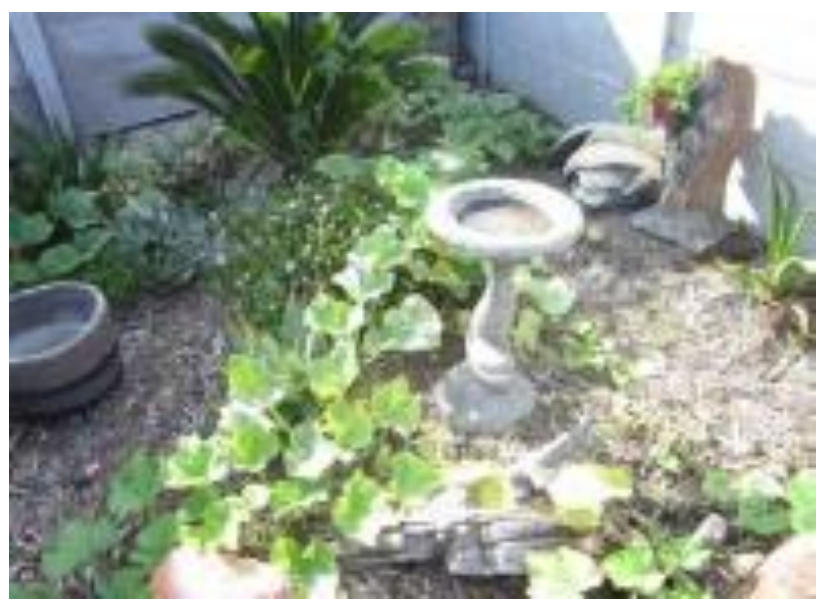

Fonte: levantamento de campo, 2018

- Troca ou Recompra (Buy Back Center) de Resíduos Recicláveis Domiciliares

O programa de Swop Shop é um programa de troca de resíduos por produtos no qual um trailer itinerante visita um bairro, uma ou duas vezes por semana, e os moradores levam seus resíduos recicláveis para trocar por pontos utilizados na troca por produtos (Figura 45).

O programa Packa Ching é um programa piloto de recompra de resíduos, iniciado no bairro de Langa que funciona desde agosto de 2017, onde os moradores também trazem seus resíduos recicláveis para venda. Os resíduos são pesados e os moradores recebem uma quantia equivalente em moeda local cujo valor é carregado em um cartão (cartão de débito da Mastercard: kilorands 
card) que pode ser utilizado em estabelecimentos comerciais. Este programa piloto está sendo executado em parceria com as empresas Mastercard, Polyco ${ }^{6}$ dentre outras (Figura 46 e Figura 48). Este setor de Minimização de Resíduos do Departamento de Resíduos Sólidos da Cidade do Cabo juntamente com as empresas parceiras irá expandir este programa para as escolas do bairro Langa.

Figura 45 trailer do programa Swop Figura 46 cartão de débito kilorands Shop

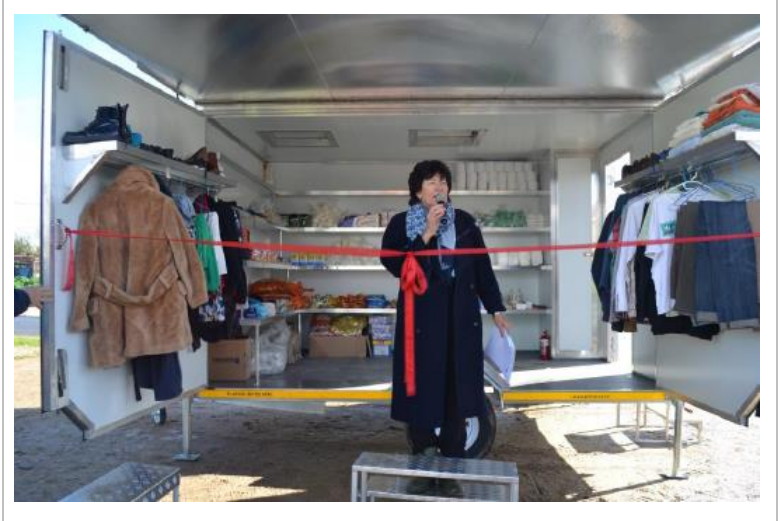

Fonte: levantamento de campo, 2018 card do programa Packa Ching

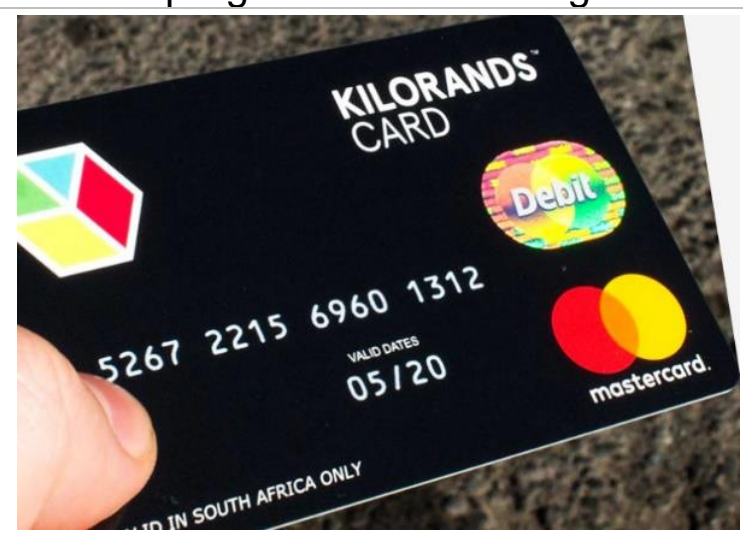

Fonte: http://www.packaching.co.za/

Figura 47 Trailer compactador do Figura 48 Moradores na fila para a programa Packa Ching pesagem dos resíduos recicláveis do programa Packa Ching

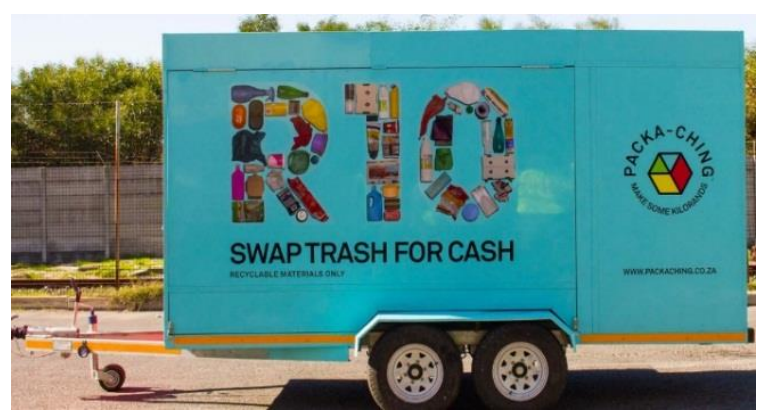

Fonte: http://www.packaching.co.za/

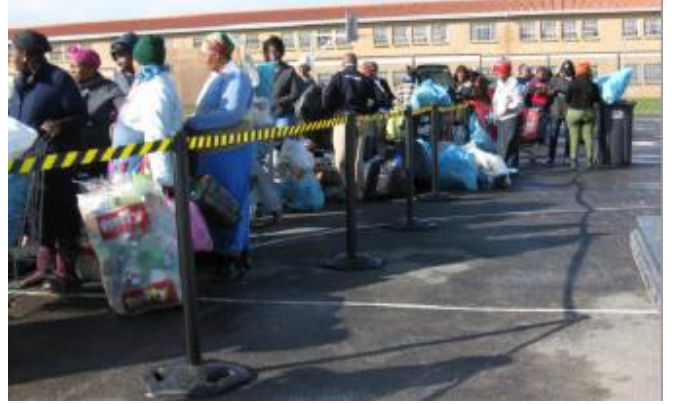

Fonte: http://www.packaching.co.za/

\footnotetext{
${ }^{6}$ Polyolefin Recycling Company ou Polyco é uma entidade sem fins lucrativos criada em 2011 que atua na redução da quantidade de resíduos de poliolefinas que são enviados para aterros com objetivo de aumentar a coleta, reciclagem, recuperação e beneficiamento sustentável de plásticos poliolefínicos: polietileno de baixa densidade (LDPE), polietileno linear de baixa densidade (LLDPE), polietileno de alta densidade (HDPE) e polipropileno (PP).
} 


\subsubsection{Políticas Públicas Aplicadas aos Resíduos Sólidos na Cidade do Cabo}

A principal política pública na área de resíduos na África do Sul foi a promulgada por meio da Lei dos Resíduos n. $.59 / 2008$ ou Waste Act (REPUBLIC OF SOUTH AFRICA, 2008) que está atrelada à implantação da Estratégia Nacional de Gerenciamento de Resíduos (REPUBLIC OF SOUTH AFRICA, 2008). Na África do Sul, o Departamento de Assuntos Ambientais, com categoria de ministério, é o responsável por editar as políticas públicas para o gerenciamento integrado de resíduos sólidos. A Lei dos Resíduos considera que:

Todos têm o direito constitucional de ter um ambiente que não é prejudicial à sua saúde e ter o ambiente protegido em benefício de gerações presentes e futuras através de medidas legislativas razoáveis e outras que:

(a) previna a poluição e a degradação ecológica;

(h) promova a conservação;

(c) assegure o desenvolvimento ecológico sustentável e o uso de recursos naturais promovendo economicamente e desenvolvimento social justificável

A Lei dos Resíduos também considera fundamental que as províncias e as municipalidades executem, como parte de suas políticas públicas, seus Planos de Gerenciamento Integrado de Resíduos Sólidos, tornando-os exequíveis para cumprir as determinações legais.

Entre 2011 e 2012, a Estratégia Nacional de Gerenciamento de Resíduos passou por revisões que impactaram as políticas públicas de gerenciamento dos resíduos sólidos. São elas:

- Os municípios foram obrigados a fornecer um ambiente propício para que as famílias reciclassem os resíduos domésticos; 
- Passou a ser obrigatória a separação dos resíduos sólidos na fonte geradora em todas as áreas metropolitanas e, para as demais áreas, a obrigatoriedade da separação dos resíduos sólidos na fonte geradora passou a ser meta a ser alcançada até o ano de 2016;

- Até 2016, todas as municipalidades deveriam deixar de enviar para os aterros sanitários $25 \%$ do total de resíduos sólidos recicláveis.

As políticas públicas para resíduos sólidos da província de Western Cape foram estabelecidas no Plano Integrado de Gestão de Resíduos 2017 - 2022 e integradas com outras de temas associados, notadamente: (i) Marco da Estratégia de Economia Verde do Cabo Ocidental 2013; (ii) Plano Integrado de Gestão de Resíduos do Cabo Ocidental 2017 - 2022; (iii) Plano Estratégico Provincial (2014 - 2019); (iv) Estratégia de Resposta às Alterações Climáticas (2014); e (v) Plano de Gestão Sustentável da Água. Em todos estes planos, os principais elementos associados aos resíduos sólidos foram: (i) o crescimento do setor de resíduos sólidos é importante para geração de renda; (ii) as parceiras entre os setores público e privado são fontes de geração de empregos; (iii) a busca pela sustentabilidade econômica está associada a mudança da economia intensiva em recursos para uma economia eficiente no uso dos recursos (WESTERN CAPE GOVERNMENTAL, 2017).

Especificamente para a Cidade do Cabo em 2009, o Estatuto Integrado de Gerenciamento de Resíduos da Cidade (CITY OF CAPE TOWN, 2009) estabeleceu a obrigatoriedade da separação dos resíduos na fonte geradora, além dos seguintes compromissos:

- Todo cidadão deve evitar a geração de resíduos ou, quando isso não puder ser evitado, minimizar a toxicidade e a quantidade de resíduos gerados;

- O gerador deve separar os resíduos com o objetivo de minimizar os impactos ambientais e armazenar os resíduos recicláveis separadamente 
dos resíduos não recicláveis e ainda deve reutilizar, reciclar ou recuperar resíduos, sempre que possível;

- Os cidadãos devem celebrar um contrato com a administração municipal ou um prestador de serviços credenciado, conforme o caso, para a coleta de resíduos. E, também, pagar as tarifas cobradas pela administração municipal pelos serviços de coleta de resíduos, de acordo com a Lei de Cobrança e Controle de Crédito da cidade;

- O gerador de resíduos pode solicitar um contentor adicional ao Departamento de Resíduos Sólidos e arcará os custos adicionais, conforme o Estatuto Tarifas da Cidade do Cabo.

As políticas públicas da Cidade do Cabo (Quadro 19) estão fundamentadas nos instrumentos legais nacional e da província (Plano de Gerenciamento Integrado de Resíduos Sólidos da província de Western Cape) que proporcionaram a base para a construção do Estatuto Integrado de Gerenciamento de Resíduos da Cidade, que é o instrumento mais significativo da gestão de resíduos. Anualmente, a administração municipal elabora Planos de Gerenciamento Integrados de Resíduos Sólidos que demonstram o cumprimento dos compromissos assumidos no período, em termos das metas estabelecidas.

Quadro 19 Políticas públicas e seus instrumentos para a gestão dos resíduos sólidos da Cidade do Cabo, 2018

\begin{tabular}{|c|c|c|}
\hline Ano & $\begin{array}{l}\text { Número Instrumento } \\
\text { Legal }\end{array}$ & Política Pública \\
\hline 2009 & $\begin{array}{l}\text { Estatuto Integrado de } \\
\text { Gerenciamento de } \\
\text { Resíduos da Cidade }\end{array}$ & $\begin{array}{l}\text { A gestão dos resíduos sólidos deve garantir } \\
\text { um ambiente seguro, saudável e sustentável } \\
\text { Obrigatoriedade para todos os geradores } \\
\text { promover a minimização da geração de } \\
\text { resíduos sólidos e proceder à separação dos } \\
\text { resíduos na fonte geradora. Eliminação dos } \\
\text { lixões ilegais. O Departamento de Resíduos } \\
\text { Sólidos deverá ter equipe própria para } \\
\text { fiscalizacão e reqular todos os prestadores de }\end{array}$ \\
\hline
\end{tabular}




\begin{tabular}{|c|c|c|}
\hline Ano & Número Instrumento & Política Pública \\
\hline & & $\begin{array}{l}\text { serviços de resíduos sólidos por meio de } \\
\text { credenciamento e garantir que os mesmos } \\
\text { cumpram seus contratos }\end{array}$ \\
\hline 2011 & $\begin{array}{l}\text { Plano de } \\
\text { Gerenciamento } \\
\text { Integrado de } \\
\text { Resíduos Sólidos } \\
2011-2012\end{array}$ & \multirow{4}{*}{$\begin{array}{l}\text { Define as metas anuais para o gerenciamento } \\
\text { de resíduos sólidos, responsáveis pela } \\
\text { execução, valores para investimento e } \\
\text { operação do sistema integrado de resíduos, } \\
\text { formato de envolvimento do mercado privado e } \\
\text { dos atores sociais }\end{array}$} \\
\hline 2012 & $\begin{array}{l}\text { Plano de } \\
\text { Gerenciamento } \\
\text { Integrado de } \\
\text { Resíduos Sólidos } \\
2012-2013\end{array}$ & \\
\hline 2013 & $\begin{array}{l}\text { Plano de } \\
\text { Gerenciamento } \\
\text { Integrado de } \\
\text { Resíduos Sólidos } \\
2013-2014\end{array}$ & \\
\hline 2015 & $\begin{array}{l}\text { Plano } \\
\text { Gerenciamento de } \\
\text { Integrado de } \\
\text { Resíduos Sólidos } \\
2015-2016\end{array}$ & \\
\hline 2017 & 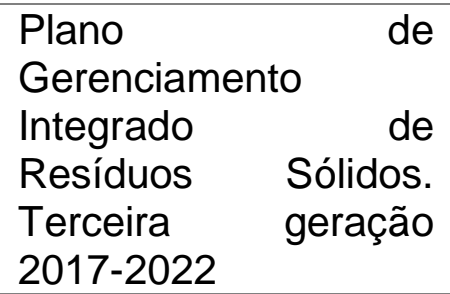 & $\begin{array}{l}\text { Define todas as estratégias operacionais, } \\
\text { apresenta o cronograma de projetos e } \\
\text { atividades para a implantação do plano }\end{array}$ \\
\hline
\end{tabular}

Fonte: levantamento de campo, 2018. 


\subsection{SÃO PAULO}

O município de São Paulo situa-se no estado de São Paulo/Brasil (Figura 49), possui uma área de $1.521,11 \mathrm{~km}^{2}$, está inserido na Região Metropolitana de São Paulo e é classificada, segundo as Nações Unidas (UN, 2016), como megacidade em função de sua população ser superior a 10 milhões de habitantes (Figura 50).

Figura 49 Localização geral do município de São Paulo, Brasil

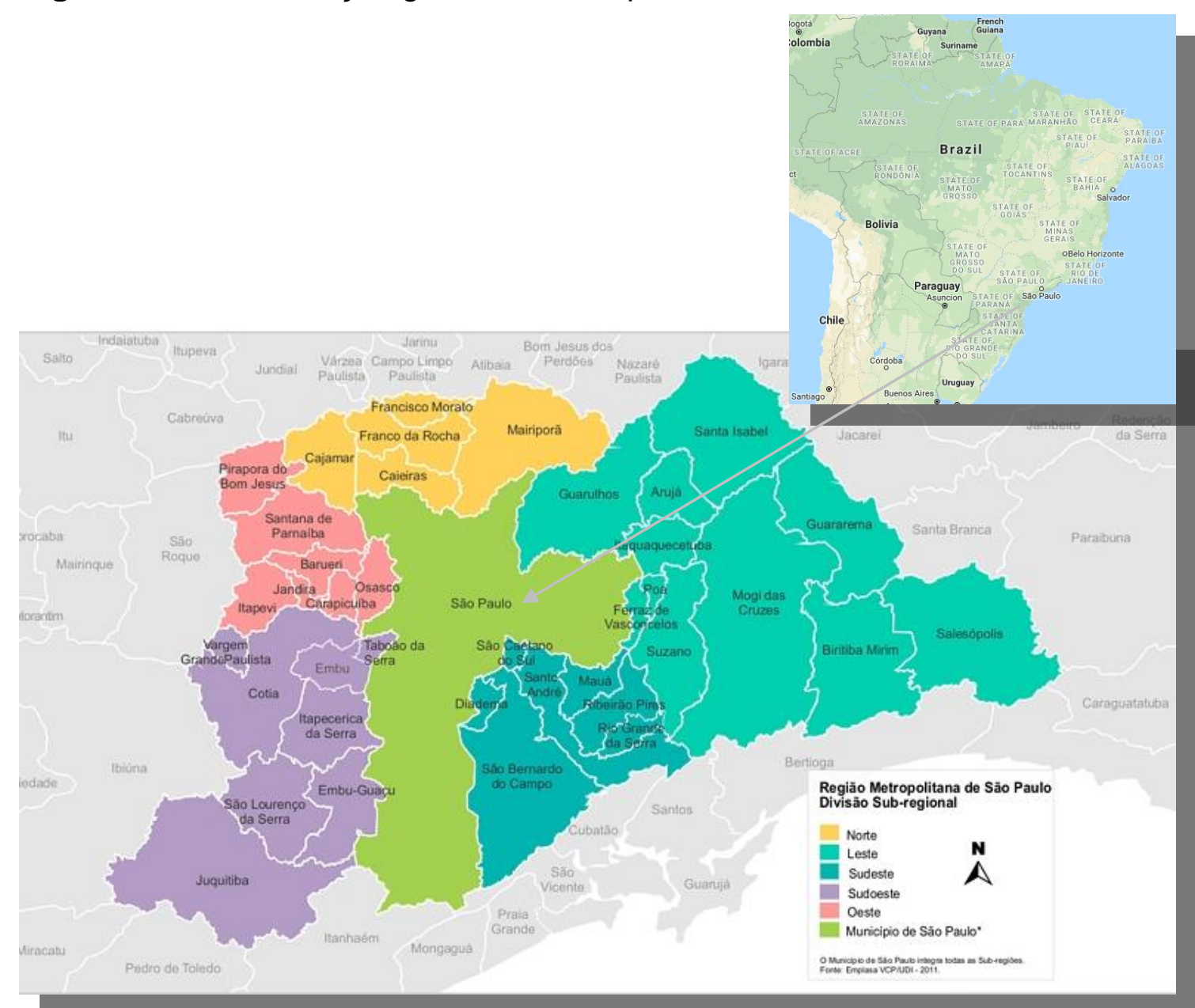

Fonte: Google Earth Pro; https://www.emplasa.sp.gov.br/RMSP, 2017. 
Tabela 17 Caracterização de São Paulo nos anos de 2010 e 2015

\begin{tabular}{|c|c|c|}
\hline \multirow{2}{*}{ Item } & \multicolumn{2}{|c|}{ Ano } \\
\hline & 2010 & 2015 \\
\hline População total (hab) (1) & $11.253 .503(1)$ & $11.581 .798(4)$ \\
\hline Número de habitações (n) & $3.574 .286(4)$ & $3.900 .375(4)$ \\
\hline Renda per capita ano (dólares) & $7.683,89(2)$ & \\
\hline $\begin{array}{l}\text { Densidade demográfica }\left(\mathrm{hab} / \mathrm{km}^{2}\right) \\
\text { (5) }\end{array}$ & $7.398,26(3)$ & $7.614,04(4)$ \\
\hline
\end{tabular}

Figura 50 Vista parcial da região central de São Paulo

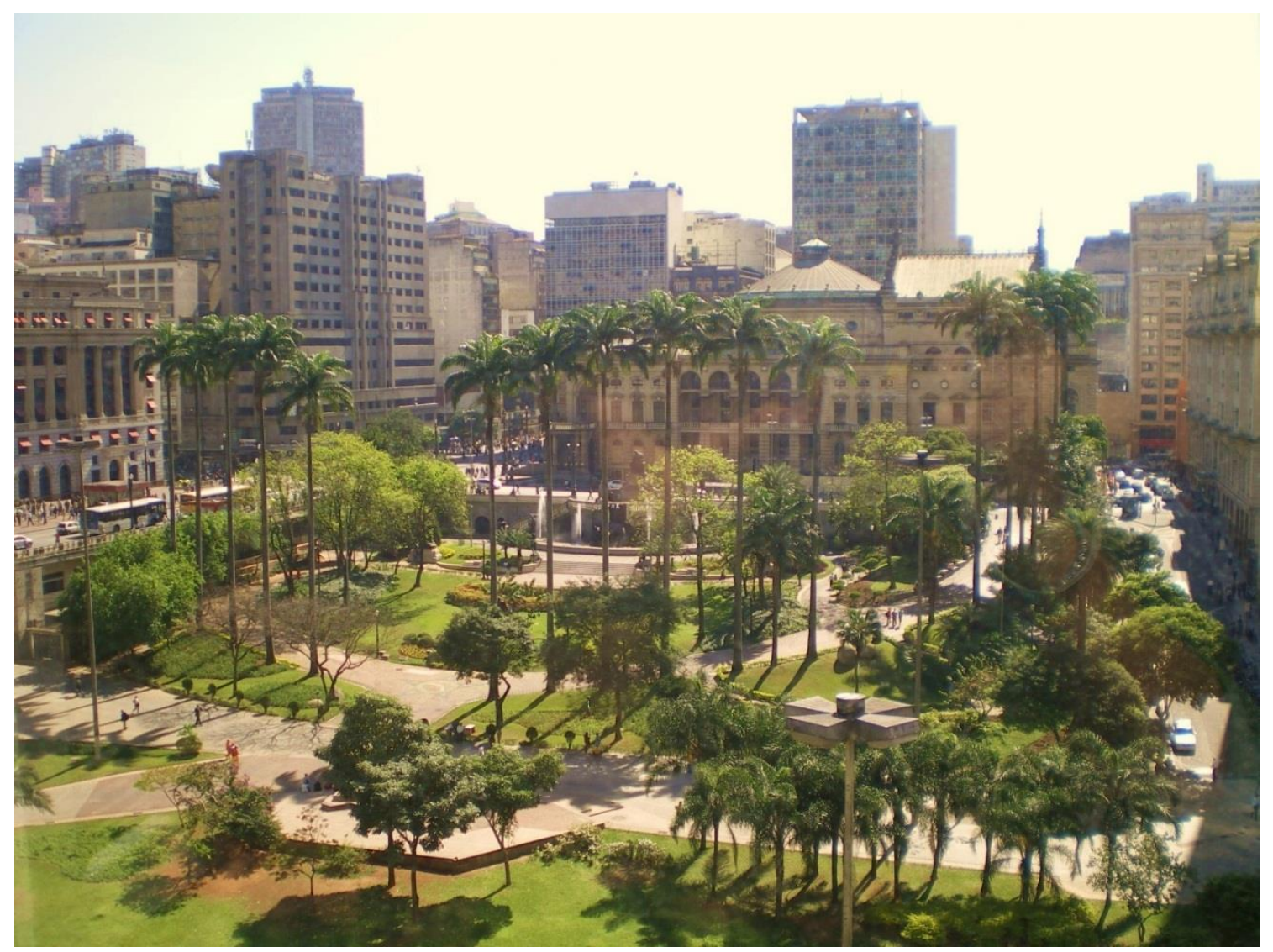

Fonte: da autora, 2010. 
O número de famílias em São Paulo é significativo, se comparado aos demais municípios estudadas, sendo que o número de pessoas por família em São Paulo e Cidade do Cabo são similares (Quadro 20).

Quadro 20 Variáveis demográficas de São Paulo em 2010

\begin{tabular}{|l|c|}
\hline Variáveis & 2010 \\
\hline Número total de famílias (1) & 3.281 .375 \\
\hline Número de pessoas por família (1) & 3,34 \\
\hline Taxa de Analfabetismo de 15 Anos e mais (\%) (2) & 3,20 \\
\hline Fonte: (1) https://cidades.ibge.gov.br/brasil/sp/sao-paulo/pesquisa/23/24161?detalhes=true., & $(2)$ \\
2016 & \\
http://infocidade.prefeitura.sp.gov.br/htmls/8_populacao_total_e_analfabeta_de_15_anos_200 \\
0_10517.html
\end{tabular}

\subsubsection{História e Tradição da Reciclagem em São Paulo}

A primeira experiência de coleta seletiva no município de São Paulo foi realizada em dezembro de 1989 com um projeto piloto no bairro de Vila Madalena em São Paulo (SÃO PAULO, 1992). Na época, a experiência piloto foi considerada bem sucedida pois foi realizado "um trabalho de divulgação e esclarecimento da população através de folhetos entregues porta a porta e de reuniões com lideranças e representantes da comunidade" (SÃO PAULO, 1992). Posteriormente foi expandida para outros bairros de São Paulo usando a coleta diferenciada com caminhões específicos em horário diferente da coleta regular e instalação de Postos de Entrega Voluntários (PEVs) instalados em "lugares públicos como parques, supermercados e escolas" (SÃO PAULO, 1992: 10).

A experiência também registrou boa participação da população. Segundo o documento "Diretrizes para a Destinação Final dos Resíduos Sólidos no Município de São Paulo", em 1992 já eram registradas 10 toneladas/dia de resíduos recicláveis coletados e enviados para a Central de Triagem e Reciclagem de Pinheiros (SÃO PAULO, 1992). 


\subsubsection{Gerenciamento dos Resíduos Sólidos Urbanos de São Paulo}

A coleta regular de Resíduos Sólidos Urbanos (RSU) do município de São Paulo, segundo informação obtida em entrevista de campo, é realizada em $100 \%$ do território municipal, três vezes por semana por empresas privadas de grande porte que detém contratos de concessão com a Autoridade Municipal de Limpeza Urbana (AMLURB). As concessionárias LOGA e ECOURBIS respondem pelos serviços definidos como divisíveis e as empresas INOVA e SOMA, respondem pelos serviços definidos como indivisíveis essenciais e indivisíveis complementares (Quadro 21), conforme a Lei Municipal 13.478/03.

Quadro 21 Serviços de limpeza urbana de resíduos sólidos em São Paulo, 2013

\begin{tabular}{|c|c|}
\hline Serviços & Definição \\
\hline DIVISÍVEIS & $\begin{array}{l}\text { I - Resíduos sólidos e materiais de varredura residenciais; } \\
\text { II - Resíduos sólidos domiciliares não-residenciais }{ }^{7} \text {, assim } \\
\text { entendidos aqueles originários de estabelecimentos públicos, } \\
\text { institucionais, de prestação de serviços, comerciais e industriais, } \\
\text { entre outros, com características de Classe 2, conforme NBR } \\
10004 \text { da ABNT - Associação Brasileira de Normas Técnicas, até } \\
200 \text { (duzentos) litros por dia; } \\
\text { III - Resíduos inertes, caracterizados como Classe } 3^{8} \text { pela norma } \\
\text { técnica referida no inciso anterior, entre os quais entulhos, terra e } \\
\text { sobras de materiais de construção que não excedam a } 50 \\
\text { (cinquenta) quilogramas diários, devidamente acondicionados; } \\
\text { IV - Resíduos de serviços de saúde, conforme definidos nesta } \\
\text { lei; } \\
\text { V - Restos de móveis, de colchões, de utensílios, de mudanças e } \\
\text { outros similares, em pedaços, até } 200 \text { (duzentos) litros } \\
\text { (volumosos); } \\
\text { VI - Resíduos sólidos originados de feiras/mercados, desde que } \\
\text { corretamente acondicionados; } \\
\text { VII - outros que vierem a ser definidos por regulamento pela } \\
\text { Autoridade Municipal de Limpeza Urbana - AMLURB }\end{array}$ \\
\hline $\begin{array}{l}\text { INDIVISÍVEIS } \\
\text { ESSENCIAIS }\end{array}$ & $\begin{array}{l}\text { I - A conservação e limpeza pública dos bens de uso comum do } \\
\text { Município; II - A varrição e asseio de vias, viadutos, elevados, } \\
\text { praças, túneis, escadarias, passagens, vielas, abrigos, } \\
\text { monumentos, sanitários e demais logradouros públicos; III - A } \\
\text { raspagem e a remoção da terra, areia, e quaisquer materiais }\end{array}$ \\
\hline
\end{tabular}

\footnotetext{
${ }^{7}$ Corresponde ao pequeno gerador (menos de 2001/dia/resíduos).

${ }^{8}$ Atualmente definido como Classe II B, segundo NBR 10.004/04.
} 


\begin{tabular}{|c|l|}
\hline Serviços & \multicolumn{1}{|c|}{ Definição } \\
\hline & $\begin{array}{l}\text { carregados pelas águas pluviais para as ruas e logradouros } \\
\text { públicos pavimentados; IV - A capinação do leito das ruas, bem } \\
\text { como o condicionamento e a coleta do produto resultante, assim }\end{array}$ \\
& $\begin{array}{l}\text { como a irrigação das vias e logradouros públicos não- } \\
\text { pavimentados, dentro da área urbana; V - A limpeza e } \\
\text { desobstrução de bueiros, bocas-de-lobo, poços de visita, galerias } \\
\text { pluviais e correlatos; VI - A remoção de animais mortos, de } \\
\text { proprietários não-identificados, de vias e logradouros públicos; } \\
\text { VII - A limpeza de áreas públicas em aberto; VIII - A limpeza de }\end{array}$ \\
\hline $\begin{array}{l}\text { INDIVISÍVEIS } \\
\text { COMPLEME }\end{array}$ & $\begin{array}{l}\text { Ón demais serviços indivisíveis de limpeza urbana, que tenham } \\
\text { NTARES }\end{array}$ \\
\hline
\end{tabular}

Fonte: Lei Municipal 13478/03

A coleta seletiva ou diferenciada é realizada para os domicílios em dias diferentes da coleta regular e recolhe os resíduos recicláveis (secos) dos bairros abrangidos por este serviço que é realizado pelas concessionárias LOGA e ECOURBIS. Os restantes dos resíduos, incluindo orgânicos são recolhidos pela coleta regular e enviados para aterro sanitário (Quadro 22).

Complementam os serviços da coleta seletiva, a coleta realizada por 41 cooperativas e associações (denominada na AMLURB como coleta solidária), todas certificadas pela AMLURB, conforme informações obtidas em uma das entrevistas realizadas. Destas, 21 possuem termo de cooperação com a AMLURB e recebem os seguintes benefícios: aluguel, pagamentos de tarifas de energia elétrica, água e IPTU, uniformes e equipamentos de proteção individual (EPI) e caminhões (AMLURB, 2017). As demais (20 cooperativas e associações) são beneficiadas somente com o recebimento de resíduos sólidos para os serviços de triagem.

Existem ainda 12 cooperativas e associações que também fazem coleta porta a porta com caminhões fornecidos pela AMLURB.

Todos os rejeitos provenientes da triagem dos resíduos secos são coletados por caminhões das concessionárias do setor de coleta que a mesma está inserida, são pesados e enviados para aterro sanitário, conforme informações obtidas nas visitas técnicas realizadas. 
Além disto, São Paulo abriga os catadores que trabalham de modo individualizado, definidos como catadores autônomos, que coletam materiais recicláveis que são comercializados por empresas menores que intermediam a compra e venda dos materiais recicláveis com indústrias chamados de Depósito de Sucatas $^{9}$ (SÃO PAULO, 2014).

No município de São Paulo, a predominância do acondicionamento pré coleta regular e/ou seletiva/diferenciada é realizada por meio de estocagem dos materiais em sacos plásticos sem padronização de capacidade, apesar da obrigatoriedade dos estabelecimentos comerciais fornecerem sacolas padronizadas nas duas categorias de separação de resíduos (Decreto Municipal n. $=55.827 / 15)$. Os contentores fornecidos pela AMLURB, via concessionárias, estão disponíveis, predominantemente, para edifícios residenciais e não abrangem todo o território municipal.

A separação dos resíduos na fonte geradora ainda não é uma obrigatoriedade no município de São Paulo, sendo os geradores convidados a participar da separação de forma voluntária em duas categorias: (i) recicláveis ou resíduos secos que devem conter papel, plástico, vidro e metais e (ii) não recicláveis pelo sistema implantado, que abrange o restante dos resíduos (matéria orgânica proveniente de restos de alimentos, podas, pequenas quantidades de inertes, etc.) (Quadro 22).

Apesar da não obrigatoriedade municipal, conforme apontado por SAMPAIO (2018), o decreto federal $n^{0}$. 6.514/2008, em seu artigo 62, inciso XIII já estabeleceu que os consumidores podem receber sanções ou multas em caso de "deixar de segregar resíduos sólidos na forma estabelecida para a coleta seletiva, quando a referida coleta for instituída pelo titular do serviço público de limpeza urbana e manejo de resíduos sólidos" (BRASIL, 2008).

\footnotetext{
${ }^{9}$ Cabe destacar que em São Paulo existem depósitos de sucatas formalizados e não formalizados.
} 
Quadro 22 Categorias de separação dos resíduos sólidos urbanos de São Paulo

\begin{tabular}{|c|c|c|}
\hline $\begin{array}{l}\text { Categorias } \\
\text { de } \\
\text { Resíduos } \\
\text { Sólidos }\end{array}$ & Composição Predominante & $\begin{array}{l}\text { Triagem ou } \\
\text { Disposição } \\
\quad \text { Final }\end{array}$ \\
\hline \multirow{4}{*}{$\begin{array}{l}\text { Recicláveis/ } \\
\text { secos }\end{array}$} & $\begin{array}{l}\text { Plásticos: garrafas, embalagens de } \\
\text { produtos de limpeza, potes de cremes, } \\
\text { xampus, tubos e canos, brinquedos, sacos, } \\
\text { sacolas e saquinhos de leite, papéis } \\
\text { plastificados, metalizados ou parafinados } \\
\text { (embalagens de biscoito, por exemplo) }\end{array}$ & \multirow{4}{*}{$\begin{array}{l}\text { Cooperativas, } \\
\text { associações e } \\
\text { Centrais } \\
\text { Mecanizadas } \\
\text { de Triagem e } \\
\text { comercialização }\end{array}$} \\
\hline & $\begin{array}{l}\text { Metais e alumínio: latinhas de cerveja e } \\
\text { refrigerante, esquadrias e molduras de } \\
\text { quadros. Metais ferrosos: molas e latas }\end{array}$ & \\
\hline & $\begin{array}{l}\text { Papel e papelão: jornais, revistas, } \\
\text { impressos em geral, caixas de papelão, } \\
\text { embalagens longa vida }\end{array}$ & \\
\hline & $\begin{array}{l}\text { Vidro: frascos, garrafas, vidros de conserva, } \\
\text { materiais não recicláveis, cerâmicas vidros } \\
\text { pirex e similares, acrílico }\end{array}$ & \\
\hline $\begin{array}{l}\text { Não } \\
\text { recicláveis } \\
\text { pelo } \\
\text { sistema } \\
\text { implantado }\end{array}$ & $\begin{array}{l}\text { Orgânicos (restos de alimentos, poda), } \\
\text { pequenas quantidades de inertes, madeira } \\
\text { e todos outros materiais que não são } \\
\text { classificados como recicláveis/secos }\end{array}$ & Aterro Sanitário \\
\hline
\end{tabular}

Fonte:AMLURB,2017.http://www.prefeitura.sp.gov.br/cidade/secretarias/regionais/amlurb/coleta _seletiva/index.php?p=4623

Em termos quantitativos, a média anual de 2006 a 2016 para a geração e coleta dos resíduos sólidos urbanos (RSU) de São Paulo foi de 5,7 milhões de toneladas/ano, sendo que os resíduos domiciliares representaram em média, cerca de $62 \%$ do total coletado de RSU. De 2015 para 2016, a quantidade total de RSU declinou, provavelmente devido a diminuição do poder aquisitivo das famílias decorrentes da crise econômica (Tabela 18) (BRAGA et al, 2017 ${ }^{10}$ ).

${ }^{10}$ Vide Apêndice 5. 
Tabela 18 Total de resíduos sólidos urbanos, domiciliares e da coleta seletiva entre 2006 e 2016 para São Paulo

\begin{tabular}{|c|c|c|c|c|c|c|c|}
\hline \multirow[b]{2}{*}{ Ano } & \multicolumn{7}{|c|}{ Resíduos Por Ano } \\
\hline & $\begin{array}{c}\text { Total RSU } \\
\text { (t) }\end{array}$ & $\%$ & $\begin{array}{c}\text { Domiciliar } \\
\text { (t) }\end{array}$ & $\%$ & $\begin{array}{l}\text { Seletiva } \\
\text { (t) }\end{array}$ & $\begin{array}{c}\% \\
\text { (seletiva/ } \\
\text { RSU) }\end{array}$ & $\begin{array}{c}\% \\
\text { (seletiva/ } \\
\text { domiciliar) }\end{array}$ \\
\hline 2006 & $5.312 .902,56$ & $100 \%$ & $3.345 .506,77$ & $63 \%$ & $22.901,74$ & $0,43 \%$ & $0,68 \%$ \\
\hline 2007 & $5.599 .850,77$ & $100 \%$ & $3.315 .734,46$ & $59 \%$ & $30.120,97$ & $0,54 \%$ & $0,91 \%$ \\
\hline 2008 & $5.905 .153,56$ & $100 \%$ & $3.454 .312,34$ & $58 \%$ & $40.965,37$ & $0,69 \%$ & $1,19 \%$ \\
\hline 2009 & $6.403 .554,51$ & $100 \%$ & $3.627 .798,35$ & $57 \%$ & $34.263,85$ & $0,54 \%$ & $0,94 \%$ \\
\hline 2010 & $5.930 .517,29$ & $100 \%$ & $3.417 .989,63$ & $58 \%$ & $33.076,73$ & $0,56 \%$ & $0,97 \%$ \\
\hline 2011 & $5.622 .013,59$ & $100 \%$ & $3.479 .114,43$ & $62 \%$ & $44.590,56$ & $0,79 \%$ & $1,28 \%$ \\
\hline 2012 & $6.429 .261,64$ & $100 \%$ & $3.799 .597,14$ & $59 \%$ & $56.918,08$ & $0,89 \%$ & $1,50 \%$ \\
\hline 2013 & $6.009 .028,04$ & $100 \%$ & $3.831 .455,19$ & $64 \%$ & $66.439,39$ & $1,11 \%$ & $1,73 \%$ \\
\hline 2014 & $5.234 .411,31$ & $100 \%$ & $3.495 .732,17$ & $67 \%$ & $60.586,50$ & $1,16 \%$ & $1,73 \%$ \\
\hline 2015 & $5.527 .293,96$ & $100 \%$ & $3.800 .496,39$ & $69 \%$ & $86.843,25$ & $1,57 \%$ & $2,29 \%$ \\
\hline 2016 & $5.230 .713,63$ & $100 \%$ & $3.585 .550,03$ & $69 \%$ & $84.652,56$ & $1,62 \%$ & $2,36 \%$ \\
\hline Média & $5.745 .881,90$ & $100 \%$ & $3.559 .389,72$ & $62 \%$ & $51.032,64$ & $0,90 \%$ & $1,428 \%$ \\
\hline
\end{tabular}

Entretanto, as quantidades de materiais secos coletados seletivamente aumentaram: em 2014 foram processadas 60.586 toneladas e já no ano seguinte, foram processadas 86.843 toneladas, ou seja, um aumento de cerca de 40\%. A taxa de coleta seletiva em relação ao total de RSU entre 2006 e 2013 foi menor que 1\% entre 2006 e 2010. A partir de 2013, aumentou sucessivamente, chegando a $1,62 \%$ no ano de 2016 . Este aumento também pode estar associado a dois fatores:

- Maior participação das cooperativas e associações de catadores, a partir de 2013, associadas as intenções ao incentivo da gestão municipal na época;

- Início das operações das centrais mecanizadas de triagem ${ }^{11}$ no meio do ano de 2014;

\footnotetext{
${ }^{11}$ Início da operação da Central Mecanizada de Triagem Carolina Maria de Jesus: julho de 2014. Início da operação da Central Mecanizada de Triagem Ponte Pequena em junho 2014. A capacidade operacional de cada Central é 250t/dia.
} 
Durante os levantamentos de campo foram obtidos relatórios técnicos de Caracterização dos Resíduos Sólidos Domiciliares realizados quadrimestralmente pelas empresas concessionarias dos serviços divisíveis LOGA e ECOURBIS, onde foram utilizados dados de 2015 para os agrupamentos noroeste e sudeste (Anexo) que subsidiaram a elaboração da Tabela 19. Os valores apresentados nas colunas "média do agrupamento" equivalem a média de todas as amostras de cada Prefeitura Regional para os meses destacados em 2015.

Tabela 19 Composição gravimétrica média dos resíduos sólidos urbanos domiciliares de São Paulo de março a setembro de 2015

\begin{tabular}{|c|c|c|c|c|c|}
\hline Material & Unidade & $\begin{array}{c}\text { Média } \\
\text { Agrupamento } \\
\text { Noroeste } \\
\text { Março a } \\
\text { Outubro } \\
2015(\%)(1)\end{array}$ & Material & Unidade & $\begin{array}{c}\text { Média } \\
\text { Agrupamento } \\
\text { Sudeste } \\
\text { Janeiro a } \\
\text { Setembro } \\
2015(\%)(2)\end{array}$ \\
\hline Total de amostra & $\%$ & $\ldots$ & $\begin{array}{l}\text { Peso Total Da } \\
\text { Amostra }(\mathrm{kg})\end{array}$ & $\mathrm{kg}$ & 529,27 \\
\hline Matéria Orgânica & $\%$ & 48,49 & $\begin{array}{l}\text { Matéria } \\
\text { Orgânica }\end{array}$ & $\%$ & 35,78 \\
\hline $\begin{array}{l}\text { Papel, Papelão e } \\
\text { Jornal }\end{array}$ & $\%$ & 10,66 & $\begin{array}{l}\text { Papel, Papelão } \\
\text { e Jornal }\end{array}$ & $\%$ & 18,55 \\
\hline $\begin{array}{l}\text { Embalagem longa } \\
\text { vida }\end{array}$ & $\%$ & 0,58 & $\begin{array}{l}\text { Embalagem } \\
\text { Longa Vida }\end{array}$ & $\%$ & 2,02 \\
\hline Embalagem PET & $\%$ & 0,56 & $\begin{array}{l}\text { Embalagem } \\
\text { PET }\end{array}$ & $\%$ & 3,11 \\
\hline Isopor \% & $\%$ & 0,22 & Isopor & $\%$ & 0,38 \\
\hline Plástico Mole & $\%$ & 11,64 & Plástico Mole & $\%$ & 9,92 \\
\hline Plástico Duro & $\%$ & 2,58 & Plástico Duro & $\%$ & 4,15 \\
\hline Metais ferrosos & $\%$ & 0,91 & $\begin{array}{l}\text { Metais } \\
\text { Ferrosos }\end{array}$ & $\%$ & 2,32 \\
\hline Pilhas e Baterias & $\%$ & - & $\begin{array}{l}\text { Pilhas e } \\
\text { Baterias }\end{array}$ & $\%$ & - \\
\hline Vidros & $\%$ & 2,40 & Vidros & $\%$ & 3,23 \\
\hline Terra e Pedra & $\%$ & 0,51 & Terra e Pedra & $\%$ & 3,62 \\
\hline Madeira & $\%$ & 0,64 & Madeira & $\%$ & 1,45 \\
\hline Trapos e panos & $\%$ & 4,54 & Trapos e Panos & $\%$ & 4,01 \\
\hline Diversos & $\%$ & 2,80 & Diversos & $\%$ & 3,33 \\
\hline Alumínio & $\%$ & 0,25 & Alumínio & $\%$ & 0,62 \\
\hline Borracha & $\%$ & 0,16 & Borracha & $\%$ & 3,03 \\
\hline
\end{tabular}




\begin{tabular}{|c|c|c|c|c|c|}
\hline Material & Unidade & $\begin{array}{c}\text { Média } \\
\text { Agrupamento } \\
\text { Noroeste } \\
\text { Março a } \\
\text { Outubro } \\
2015(\%)(1)\end{array}$ & Material & Unidade & $\begin{array}{c}\text { Média } \\
\text { Agrupamento } \\
\text { Sudeste } \\
\text { Janeiro a } \\
\text { Setembro } \\
2015(\%)(2)\end{array}$ \\
\hline $\begin{array}{l}\text { Fraldas/Papel } \\
\text { Higiênico }\end{array}$ & $\%$ & 11,76 & $\begin{array}{l}\text { Fraldas e } \\
\text { Absorventes }\end{array}$ & $\%$ & 4,18 \\
\hline Espuma & $\%$ & 0,54 & Espuma & $\%$ & 1,97 \\
\hline Lixo Eletrônico & $\%$ & 0,17 & $\begin{array}{l}\text { Resíduo } \\
\text { Eletrônico }\end{array}$ & $\%$ & 5,64 \\
\hline $\begin{array}{l}\text { Perdas no } \\
\text { Processo }\end{array}$ & $\%$ & 0,59 & $\begin{array}{l}\text { Perdas no } \\
\text { Processo }\end{array}$ & $\%$ & 0,18 \\
\hline
\end{tabular}

Fonte: Amlurb.

Nota: (...) Informação não disponível. (1) LOGA. Relatório De Caracterização Dos Resíduos Sólidos Domiciliares Do Município De São Paulo. Agrupamento Noroeste. '(2) Fonte: ECOURBIS. Caracterização Dos Resíduos Sólidos Domiciliares Do Município De São Paulo. Agrupamento Sudeste. Primeiro Quadrimestre 2015. Segundo Quadrimestre 2015. Adaptado.

Conforme pode ser observado na Tabela 19, há algumas diferenças entre os agrupamentos Noroeste e Sudeste: a predominância de matéria orgânica é mais significativa no agrupamento Noroeste e, em ambos os agrupamentos, nota-se uma redução das quantidades de matéria orgânica nos resíduos gerados, quando comparados com os valores mencionados pelo Plano de Gerenciamento Integrado de Resíduos Sólidos (PGIRS):

a composição dos resíduos domiciliares obtida pela análise gravimétrica dos resíduos coletados por meio de amostra significativa do conjunto, realizada no primeiro quadrimestre de 2012. Pode-se ver que $51 \%$ dos resíduos domiciliares são orgânicos, compostáveis, $32 \%$ são resíduos recicláveis secos, compreendendo papel, plástico, vidro e metal, e $17 \%$ são considerados rejeitos (PGIRS, 2014)

Para os resíduos recicláveis secos (papel, plásticos, vidro e metais) também se observa um aumento, quando comparados aos dados do PGIRS de 2014 com os dados da Tabela 19, referentes a 2015.

As taxas de coleta seletiva de resíduos sólidos domiciliares, em geral, aumentaram paulatinamente, ao longo do período estudado, em todas as Prefeituras Regionais. Entretanto em relação à meta da administração municipal universalizar a coleta seletiva para todo o território paulistano 
(PGIRS, 2014), constata-se que ainda não foi atingida: as taxas de coleta seletiva domiciliares são inferiores às quantidades de resíduos domiciliares coletados (Tabela 20).

Tabela 20 Taxa de coleta seletiva em relação ao total de resíduos sólidos domiciliares por Prefeitura Regional entre 2006 e 2016 para São Paulo

\begin{tabular}{|c|c|c|c|c|c|c|c|c|c|c|c|}
\hline \multirow{2}{*}{$\begin{array}{l}\text { Prefeituras } \\
\text { Regionais }\end{array}$} & \multicolumn{11}{|c|}{ Seletiva/Domiciliar } \\
\hline & 006 & 007 & 200 & 2000 & 2010 & 2011 & 2012 & 013 & 014 & 2015 & 2016 \\
\hline & $38 \%$ & $47 \%$ & $61 \%$ & $0,60 \%$ & $0,77 \%$ & $0,95 \%$ & $1,10 \%$ & $1,05 \%$ &, $71 \%$ & ,44\% & ,25\% \\
\hline Butantã & $72 \%$ & 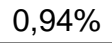 & 77 & $\%$ & $\%$ & $6 \%$ & $3 \%$ & 18\% & $95 \%$ & $\%$ & $28 \%$ \\
\hline Campo L & & $32 \%$ & 3601 & $29 \%$ & & & & & & & $25 \%$ \\
\hline & 50 & ,97\% & $1,70 \%$ & $1,88 \%$ & $1,81 \%$ & $1,78 \%$ & $2,04 \%$ & $2,26 \%$ & ,18\% & $4,23 \%$ & $60 \%$ \\
\hline Casa Verde & & & 0,67 & & $\%$ & & 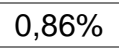 & & & & ),79\% \\
\hline Cid & & & & & & & & & & & \\
\hline $\begin{array}{l}\text { Cid } \\
\text { Tira }\end{array}$ & $00 \%$ & $0,00 \%$ & $0,09 \%$ & 0 , & 0 , & $\%$ & $\%$ & $\%$ & $\%$ & $\%$ & $37 \%$ \\
\hline Ermel & $0,00 \%$ & $0,00 \%$ & $0,00 \%$ & & & & & & & & $2,93 \%$ \\
\hline & 51 & ,47 & $0,62 \%$ & 0,5 & 0 & 0 & & $\%$ & $68 \%$ & ,83\% & , $81 \%$ \\
\hline Gua & $0,00 \%$ & . & $0,00 \%$ & $0,00 \%$ & $\%$ & $\%$ & $\%$ & $\%$ & $\%$ & $\%$ & $\%$ \\
\hline Ipir & & & & & & & & & & & \\
\hline Itair & & & $\%$ & & & & & & & & \\
\hline Itaquera & 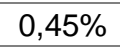 & $\%$ & $89 \%$ & $\%$ & $\%$ & $\%$ & & & & & $5 \%$ \\
\hline & & & $\%$ & 6 & & $\%$ & & & & & $80 \%$ \\
\hline & $28 \%$ & $0,45 \%$ & $0,56 \%$ & $0,30 \%$ & $0,50 \%$ & $0,42 \%$ & $1,04 \%$ & $1,28 \%$ & $0,32 \%$ & $0,62 \%$ & $58 \%$ \\
\hline Lapa & $50 \%$ & $48 \%$ & $53 \%$ & 6 & $\%$ & $\%$ & $\%$ & $\%$ & $\%$ & $\%$ & $\%$ \\
\hline $\begin{array}{l}M \\
G\end{array}$ & $0,70 \%$ & $0,89 \%$ & $0,83 \%$ & $0,59 \%$ & $0,51 \%$ & $0,87 \%$ & $0,84 \%$ & $0,73 \%$ & $1,02 \%$ & $0,98 \%$ & $0,84 \%$ \\
\hline Mbo & & & & & & & & & & & \\
\hline Mo & & & & & & & & & & & \\
\hline Parelhe & 0 & $\%$ & $\%$ & $\%$ & $\%$ & $\%$ & $\%$ & $\%$ & $\%$ & $\%$ & $01 \%$ \\
\hline Penha & & & & & & & & & & & $07 \%$ \\
\hline Perus & & & 810 & $00 \%$ & & & & & & & \\
\hline & & & 2,40 & & $\%$ & $\%$ & $\%$ & $\%$ & & $\%$ & \\
\hline $\begin{array}{l}\text { Pirit } \\
\text { Jara }\end{array}$ & $0,30 \%$ & $0,55 \%$ & $0,58 \%$ & 0 & 0 & $0,72 \%$ & $0,65 \%$ & $0,98 \%$ & $1,45 \%$ & $\%$ & $1,31 \%$ \\
\hline $\begin{array}{l}\text { Santana/ } \\
\text { Tucuruvi }\end{array}$ & $0,78 \%$ & $1,12 \%$ & $1,68 \%$ & $1,31 \%$ & $0,88 \%$ & $1,57 \%$ & $1,57 \%$ & $\%$ & $\%$ & $\%$ & $2,91 \%$ \\
\hline Sant & & & & & & & & & & & $21 \%$ \\
\hline & & & & & $0,36 \%$ & $0,08 \%$ & $0,31 \%$ & $0,76 \%$ & $0,99 \%$ & $0,53 \%$ & \\
\hline $\begin{array}{l}\text { São Miguel } \\
\text { Paulista }\end{array}$ & 10 & \% & 0, & 0 , & 0 & 0 & 0 & $0,00 \%$ & $\%$ & $\%$ & $0,45 \%$ \\
\hline Sapopemba & & & & & & & & $0,74 \%$ & $0,76 \%$ & $0,92 \%$ & \\
\hline 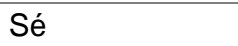 & 1,1170 & $1,01 \%$ & $2,0<\%$ & $<, 07 \%$ & $2,14 \%$ & $2,74 \%$ & $2,94 \%$ & $3,46 \%$ & $3,14 \%$ & $3,68 \%$ & $3,51 \%$ \\
\hline
\end{tabular}




\begin{tabular}{crrrrrrrrrrr|}
\hline $\begin{array}{c}\text { Prefeituras } \\
\text { Regionais }\end{array}$ & $\mathbf{2 0 0 6}$ & $\mathbf{2 0 0 7}$ & $\mathbf{2 0 0 8}$ & $\mathbf{2 0 0 9}$ & $\mathbf{2 0 1 0}$ & $\mathbf{2 0 1 1}$ & $\mathbf{2 0 1 2}$ & $\mathbf{2 0 1 3}$ & $\mathbf{2 0 1 4}$ & $\mathbf{2 0 1 5}$ & $\mathbf{2 0 1 6}$ \\
\cline { 2 - 10 } \\
Vila Mariana & $1,87 \%$ & $2,67 \%$ & $3,77 \%$ & $1,82 \%$ & $2,79 \%$ & $4,98 \%$ & $5,32 \%$ & $6,74 \%$ & $7,11 \%$ & $9,69 \%$ & $\begin{array}{r}10,06 \\
\%\end{array}$ \\
\hline Vila Prudente & $0,30 \%$ & $0,38 \%$ & $0,41 \%$ & $0,57 \%$ & $1,11 \%$ & $1,15 \%$ & $1,32 \%$ & $1,42 \%$ & $2,89 \%$ & $2,40 \%$ & $2,58 \%$ \\
\hline
\end{tabular}

Fonte: SISCOR, 2017

Entretanto, quando se analisa as taxas de coleta seletiva dos resíduos domiciliares espacializadas nos territórios de Prefeituras Regionais para 2016, verifica-se que existem na região mais central do município, a Prefeitura Regional de Vila Mariana que segregou na fonte, cerca de $10 \%$ dos seus resíduos domiciliares, ou seja, a maior taxa de coleta seletiva em 2016, quando comparado as demais Prefeituras Regionais. Imediatamente no entorno à Prefeitura Regional de Vila Mariana, situam-se as Prefeituras Regionais de Pinheiros, Santo Amaro, Jabaquara, Ipiranga, Sé e Lapa que possuem taxas de coleta seletiva domiciliar entre 2,94\% e 5,91\% (Figura 51).

Mais afastadas das porções mais centrais do município estão as Prefeituras Regionais de Butantã, Campo Limpo, Cidade Ademar, Vila Prudentes, Mooca e Santana/Tucuruvi que possuem taxas de coleta seletiva domiciliar entre 1,32\% e 2,93\% (Figura 51).

Particularmente para as porções mais periféricas das regiões Norte (Pirituba, Freguesia/Brasilândia, casa Verde/Cachoeirinha, Vila Maria/Vila Guilherme) e Leste (Aricanduva, Sapopemba, Penha, São Mateus, Itaquera) do município de São Paulo, as taxas de coleta seletiva domiciliar ficaram entre 0,57\% e 1,31\% no ano de 2016 (Figura 51).

Por fim, as Prefeituras Regionais de Perus, Jaçanã/Tremembé, São Miguel, Itaim Paulista, Guaianazes, Cidade Tiradentes, M'Boi Mirim e Parelheiros possuem as menores taxas de coleta seletiva domiciliares e situamse nas bordas do território paulistano, com percentuais bem inferiores às demais Prefeituras Regionais: entre $0,01 \%$ e $0,58 \%$ (Figura 51). 
Figura 51 Taxa de coleta seletiva domiciliar por Prefeitura Regional, São Paulo, Brasil, 2016

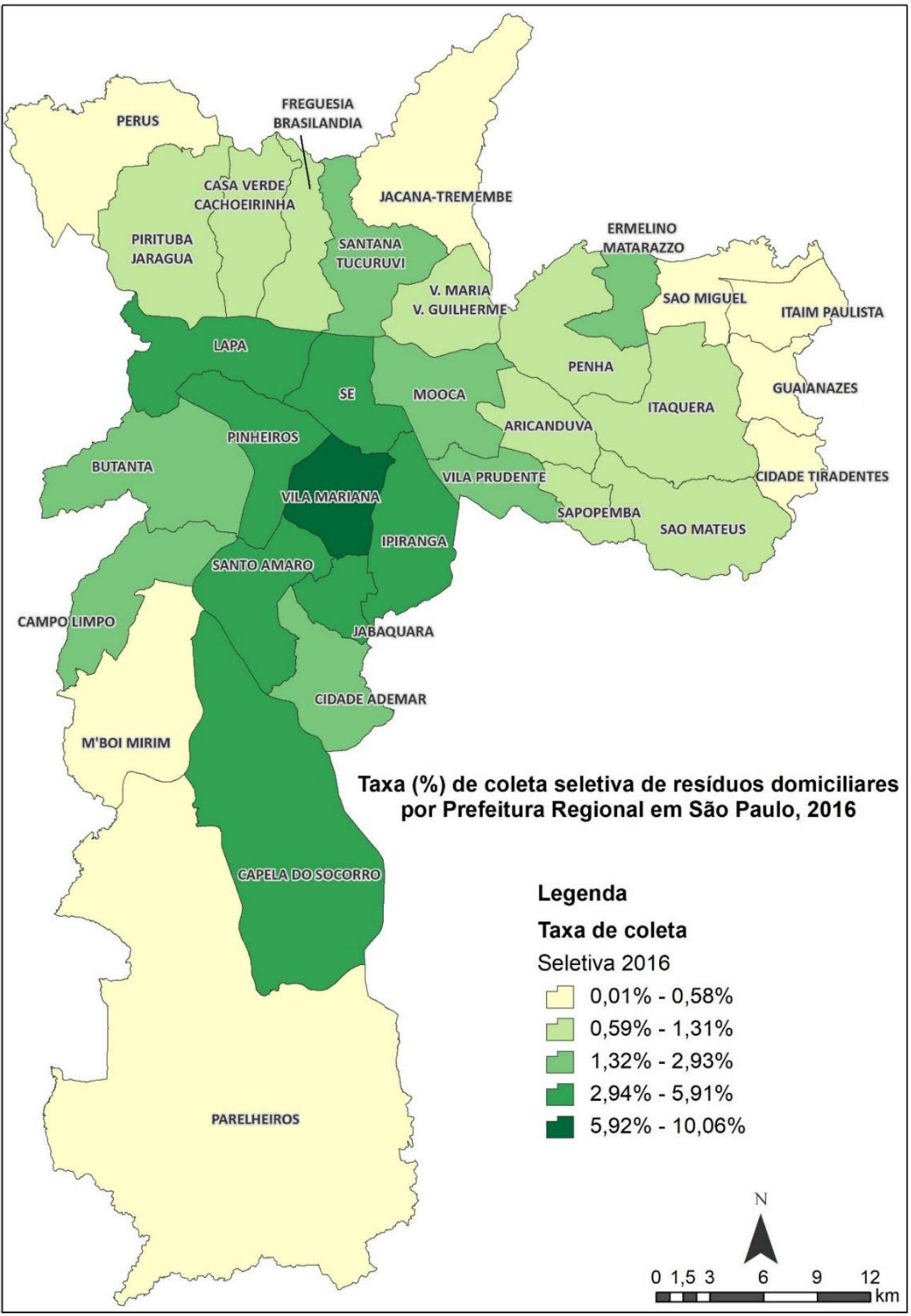

Elaboração: a autora 
Conforme informações obtidas durante os levantamentos de campo, os dados quantitativos da coleta seletiva de resíduos sólidos correspondem a 3 métodos executivos e foram registradas nos SISCOR como:

- Coleta seletiva diferenciada: realizada pelas concessionárias em dias distintos da coleta regular com caminhões específicos que recolhem resíduos domiciliares recicláveis (secos) e são encaminhados para pesagem, antes de serem processados nas Centrais Mecanizadas e/ou cooperativas e associações de catadores;

- Coleta seletiva solidária: correspondem as quantidades de resíduos sólidos das concessionárias enviadas para as cooperativas e associações de catadores e incluem, quantidades de resíduos coletados por algumas cooperativas e associações que executam estas atividades;

- Resíduos recicláveis descartados nos Postos de Entrega Voluntária (PEVs): todos os resíduos descartados nos PEVs instalados no município são coletados e pesados, antes de serem encaminhados para processamento;

Assim, com base em informações do ano de 2016 do SISCOR foi possível verificar por Prefeitura Regional quais das coletas seletivas foram as mais representativas para as taxas de coleta seletiva domiciliar apresentada anteriormente na Tabela 20.

Conforme pode ser observado na Tabela 21, em geral, a predominância dos serviços oferecidos para coleta seletiva domiciliar em 2016 foi da coleta diferenciada realizada pelas concessionárias.

Tabela 21 Tipos de coleta seletiva de resíduos sólidos domiciliares em São Paulo em 2016

\begin{tabular}{lccccccc}
\hline \multirow{2}{*}{$\begin{array}{l}\text { Prefeituras } \\
\text { Regionais }\end{array}$} & Total $(\mathbf{t})$ & \multicolumn{2}{c}{$\begin{array}{c}\text { Seletiva de } \\
\text { PEV }\end{array}$} & \multicolumn{2}{c}{$\begin{array}{c}\text { Seletiva } \\
\text { Diferenciada }\end{array}$} & \multicolumn{2}{c}{ Seletiva Solidária } \\
\cline { 3 - 8 } & & $\mathbf{t}$ & $\%$ & $\mathbf{t}$ & $\%$ & $\mathbf{t}$ & $\%$ \\
\hline $\begin{array}{l}\text { Aricanduva/ } \\
\text { Formosa }\end{array}$ & $1.139,08$ & 54,47 & 4,78 & 938,88 & 82,42 & 145,73 & 12,79 \\
\hline
\end{tabular}




\begin{tabular}{|c|c|c|c|c|c|c|c|}
\hline \multirow{2}{*}{$\begin{array}{l}\text { Prefeituras } \\
\text { Regionais }\end{array}$} & \multirow[t]{2}{*}{ Total (t) } & \multicolumn{2}{|c|}{$\begin{array}{r}\text { Seletiva de } \\
\text { PEV }\end{array}$} & \multicolumn{2}{|c|}{$\begin{array}{c}\text { Seletiva } \\
\text { Diferenciada }\end{array}$} & \multicolumn{2}{|c|}{ Seletiva Solidária } \\
\hline & & $\mathbf{t}$ & $\%$ & $\mathbf{t}$ & $\%$ & $\mathbf{t}$ & $\%$ \\
\hline Butantã & $3.582,22$ & 13,47 & 0,38 & $2.480,86$ & 69,25 & 1087,89 & 30,37 \\
\hline $\begin{array}{l}\text { Campo } \\
\text { Limpo }\end{array}$ & $4.251,78$ & 0 & 0 & $4.251,78$ & 100,00 & 0 & 0 \\
\hline $\begin{array}{l}\text { Capela do } \\
\text { Socorro }\end{array}$ & $6.509,58$ & 0 & 0 & $4.845,96$ & 74,44 & $1.663,62$ & 25,56 \\
\hline Casa Verde & 823,87 & 0 & 0 & 765,87 & 92,96 & 58 & 7,04 \\
\hline $\begin{array}{l}\text { Cidade } \\
\text { Ademar }\end{array}$ & $2.505,25$ & 62,38 & 2,49 & $2.442,87$ & 97,51 & 0 & 0,00 \\
\hline $\begin{array}{l}\text { Cidade } \\
\text { Tiradentes }\end{array}$ & 160,89 & 0 & 0 & 160,62 & 99,83 & 0,27 & 0,17 \\
\hline $\begin{array}{l}\text { Ermelino } \\
\text { Matarazzo }\end{array}$ & $1.819,20$ & 0,74 & 0,04 & $1.522,85$ & 83,71 & 295,61 & 16,25 \\
\hline $\begin{array}{l}\text { Freguesia/B } \\
\text { rasilandia }\end{array}$ & $1.012,82$ & 1,20 & 0,12 & 956,5 & 94,44 & 55,12 & 5,44 \\
\hline Guaianases & 252,23 & 0,54 & 0,21 & 189,21 & 75,01 & 62,48 & 24,77 \\
\hline Ipiranga & $5.102,89$ & 44,86 & 0,88 & $4.453,09$ & 87,27 & 604,94 & 11,85 \\
\hline $\begin{array}{l}\text { Itaim } \\
\text { Paulista }\end{array}$ & 330,97 & 0 & 0,00 & 0 & 0,00 & 330,97 & 100,0 \\
\hline Itaquera & $1.247,65$ & 99,16 & 7,95 & 872,29 & 69,91 & 276,2 & 22,14 \\
\hline Jabaquara & $2.671,68$ & 196,20 & 7,34 & $2.475,48$ & 92,66 & 0 & 0,00 \\
\hline $\begin{array}{l}\text { Jacana / } \\
\text { Tremembe }\end{array}$ & 518,51 & 0 & & 477,83 & 92,15 & 40,68 & 7,85 \\
\hline Lapa & $7.175,25$ & 0 & & $6.374,65$ & 88,84 & 800,60 & 11,16 \\
\hline $\begin{array}{l}\text { Maria/Guilhe } \\
\text { rme }\end{array}$ & 952,56 & 0 & & 902,21 & 94,71 & 50,35 & 5,29 \\
\hline Mboi Mirim & 289,87 & 0 & & 289,87 & 100,00 & 0 & 0,00 \\
\hline Mooca & $3.267,21$ & 0 & & $2.182,66$ & 66,81 & $1.084,55$ & 33,19 \\
\hline Parelheiros & 2,56 & 0 & & 0 & 0,00 & 2,56 & 100,00 \\
\hline Penha & $1.564,02$ & 2,09 & 0,13 & $1.219,67$ & 77,98 & 342,26 & 21,88 \\
\hline Perus & 22,86 & 0 & 0 & 0 & 0 & 22,86 & 100,00 \\
\hline Pinheiros & $7.879,98$ & 0 & 0 & $7.166,24$ & 90,94 & 713,74 & 9,06 \\
\hline $\begin{array}{l}\text { Pirituba/Jara } \\
\text { guá }\end{array}$ & $1.789,46$ & 0 & 0 & 547,28 & 30,58 & $1.242,18$ & 69,42 \\
\hline $\begin{array}{l}\text { Santana/Tuc } \\
\text { uruvi }\end{array}$ & $3.144,47$ & 0 & 0 & $2.507,68$ & 79,75 & 636,79 & 20,25 \\
\hline $\begin{array}{l}\text { Santo } \\
\text { Amaro }\end{array}$ & $5.173,90$ & 0 & 0 & $4.984,7$ & 96,34 & 189,2 & 3,66 \\
\hline Sao Mateus & $1.395,37$ & 0 & 0 & 0 & 0 & $1.395,37$ & 100,00 \\
\hline $\begin{array}{l}\text { Sao Miguel } \\
\text { Paulista }\end{array}$ & 445,69 & 0 & 0 & 0 & 0 & 445,69 & 100,00 \\
\hline Sapopemba & 714,32 & 53,55 & 7,50 & 660,77 & 92,50 & 0 & 0,00 \\
\hline Sé & $6.388,96$ & 265,85 & 4,16 & $5.309,62$ & 83,11 & 813,49 & 12,73 \\
\hline $\begin{array}{l}\text { Vila } \\
\text { Mariana }\end{array}$ & $12.283,94$ & 0 & 0 & $12.248,57$ & 99,71 & 35,37 & 0,29 \\
\hline Vila & $1.864,10$ & 0 & 0 & $1.858,98$ & 99,73 & 5,12 & 0,27 \\
\hline
\end{tabular}




\begin{tabular}{|c|c|c|c|c|c|c|c|}
\hline \multirow{2}{*}{$\begin{array}{l}\text { Prefeituras } \\
\text { Regionais }\end{array}$} & \multirow[t]{2}{*}{ Total $(t)$} & \multicolumn{2}{|c|}{$\begin{array}{r}\text { Seletiva de } \\
\text { PEV }\end{array}$} & \multicolumn{2}{|c|}{$\begin{array}{c}\text { Seletiva } \\
\text { Diferenciada }\end{array}$} & \multicolumn{2}{|c|}{ Seletiva Solidária } \\
\hline & & $t$ & $\%$ & $t$ & $\%$ & $t$ & $\%$ \\
\hline \multicolumn{8}{|l|}{ Prudente } \\
\hline Total & $86.283,14$ & 794,51 & & $73.086,99$ & & $\begin{array}{r}12.401,6 \\
4\end{array}$ & \\
\hline
\end{tabular}

Fonte: SISCOR, 2017.

A participação dos cidadãos na entrega dos resíduos recicláveis (secos) foi reduzida, quando comparada as demais formas de coleta seletiva e provavelmente, este fato pode estar associado a reduzida atuação da AMLURB na divulgação da existência dos PEVs e da própria coleta seletiva. Conforme apontado por SAMPAIO (2018), a coleta seletiva passou por uma reestruturação onde foram criados núcleos gestores (Educação Ambiental e Comunicação, Logística Reversa, Recicláveis Secos) na AMLURB por meio de portarias específicas para execução das políticas públicas de resíduos sólidos do PGIRS entretanto, a atuação dos núcleos se mostrou nula conforme resposta obtida por SAMPAIO em sua consulta formal à AMLURB:

Quando consultada a respeito das atividades dos referidos núcleos, via Portal da Transparência, desde sua criação até fevereiro de 2018, a AMLURB respondeu que "os núcleos gestores se encontram em fase de estudos, portanto, ainda não há resultados concretos a serem divulgados. Após essa fase, os resultados serão encaminhados" (SAMPAIO, 2018: 107).

A representatividade da coleta seletiva domiciliar pelas cooperativas e associações de catadores em 2016 também foi menor, quando comparada a coleta diferenciada (Figura 52): somente em 4 Prefeituras Regionais, a coleta solidária é a predominante em termos de triagem dos resíduos sólidos domiciliares (Itaim Paulista, Parelheiros, Perus, São Mateus e São Miguel Paulista) (Figura 53). 
Figura 52 Percentual dos tipos de coleta seletiva em 2016 para São Paulo \% Resíduos sólidos domiciliares por tipo de coleta com segregação na fonte em São Paulo, 2016

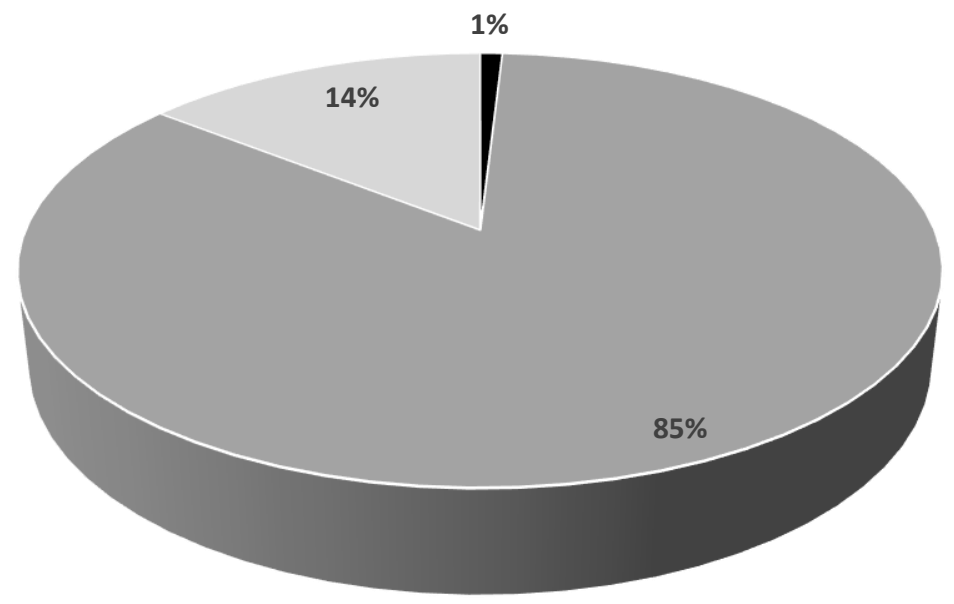

- SELETIVA DE PEV " SELETIVA DIFERENCIADA " SELETIVA SOLIDARIA

Fonte: SISCOR, 2017

As Prefeituras Regionais com maiores taxas de coleta seletiva de resíduos domiciliares em 2016, tiveram seus resíduos recicláveis recolhidos, predominantemente, pela coleta diferenciada, conforme pode ser observado na Figura 53.

Dentre as Prefeituras Regionais, cabe destacar que aquelas com maiores quantidades de resíduos sólidos urbanos em 2016, não necessariamente são aquelas com maiores taxas de coleta seletiva (Quadro 23).

Quadro 23 Ranking de coleta de resíduos sólidos domiciliares por Prefeituras Regionais de São Paulo, Brasil, em 2016

\begin{tabular}{|c|l|c|c|}
\hline Ranking & Prefeituras Regionais & $\begin{array}{c}\text { Resíduos Domiciliares } \\
\text { 2016 (t) }\end{array}$ & $\begin{array}{c}\% \text { Coleta } \\
\text { Seletiva/ } \\
\text { Resíduos } \\
\text { Domiciliares }\end{array}$ \\
\hline $1^{\circ} \stackrel{\text { Sé }}{2^{\circ}}$ & Campo Limpo & $182.152,97$ & $3,51 \%$ \\
\hline
\end{tabular}




\begin{tabular}{|c|c|c|c|}
\hline Ranking & Prefeituras Regionais & $\begin{array}{c}\text { Resíduos Domiciliares } \\
2016(t)\end{array}$ & $\begin{array}{c}\text { \% Coleta } \\
\text { Seletiva/ } \\
\text { Resíduos } \\
\text { Domiciliares }\end{array}$ \\
\hline $3^{\circ}$ & Capela Do Socorro & $173.736,58$ & $3,60 \%$ \\
\hline $4^{\circ}$ & M'boi Mirim & $158.783,63$ & $0,18 \%$ \\
\hline $5^{0}$ & Butantã & $157.497,64$ & $2,28 \%$ \\
\hline $6^{\circ}$ & Mooca & $152.384,30$ & $2,14 \%$ \\
\hline $7^{0}$ & Itaquera & $146.374,60$ & $0,85 \%$ \\
\hline $8^{\circ}$ & Penha & $145.636,97$ & $1,07 \%$ \\
\hline 90 & Ipiranga & $143.680,09$ & $3,53 \%$ \\
\hline $10^{\circ}$ & Pirituba / Jaraguá & $136.428,00$ & $1,31 \%$ \\
\hline $11^{\circ}$ & Pinheiros & $134.865,64$ & $5,84 \%$ \\
\hline $12^{\circ}$ & Cidade Ademar & $125.744,80$ & $1,90 \%$ \\
\hline $13^{\circ}$ & Freguesia/Brasilândia & $125.601,50$ & $0,81 \%$ \\
\hline $14^{\circ}$ & São Mateus & 121.900 .29 & $1,12 \%$ \\
\hline $15^{\circ}$ & Lapa & $121.345,01$ & $5,91 \%$ \\
\hline $16^{\circ}$ & Vila Mariana & $116.995,51$ & $10,06 \%$ \\
\hline $17^{\circ}$ & Maria / Guilherme & $112.868,28$ & $0,84 \%$ \\
\hline $18^{\circ}$ & Santana / Tucuruvi & 108.125 .06 & $2,91 \%$ \\
\hline $19^{\circ}$ & Casa Verde & 103.552 .25 & $0,79 \%$ \\
\hline $20^{\circ}$ & São Miguel Paulista & $98.583,18$ & $0,45 \%$ \\
\hline $21^{\circ}$ & Santo Amaro & $94.236,07$ & $5,21 \%$ \\
\hline $22^{\circ}$ & Itaim Paulista & $92.125,48$ & $0,36 \%$ \\
\hline $23^{\circ}$ & Aricanduva/Formosa & 90.615 .09 & $1,25 \%$ \\
\hline $24^{\circ}$ & Jaçanã/Tremembé & $89.002,53$ & $0,58 \%$ \\
\hline $25^{\circ}$ & Sapopemba & $81.059,81$ & $0,88 \%$ \\
\hline $26^{\circ}$ & Vila Prudente & $71.986,82$ & $2,58 \%$ \\
\hline $27^{\circ}$ & Guaianases & $68.505,41$ & $0,36 \%$ \\
\hline $28^{\circ}$ & Jabaquara & $66.831,84$ & $3,80 \%$ \\
\hline $29^{\circ}$ & Ermelino Matarazzo & $61.524,49$ & $2,93 \%$ \\
\hline $30^{\circ}$ & Perus & $44.617,21$ & $0,05 \%$ \\
\hline $31^{\circ}$ & Cidade Tiradentes & $43.307,12$ & $0,37 \%$ \\
\hline $32^{\circ}$ & Parelheiros & $36.187,40$ & $0,01 \%$ \\
\hline
\end{tabular}

Fonte: SISCOR

Elaboração: a autora 
Figura 53 Tipo de coleta seletiva de resíduos domiciliares e entregues em PEV por Prefeitura Regional em São Paulo, 2016

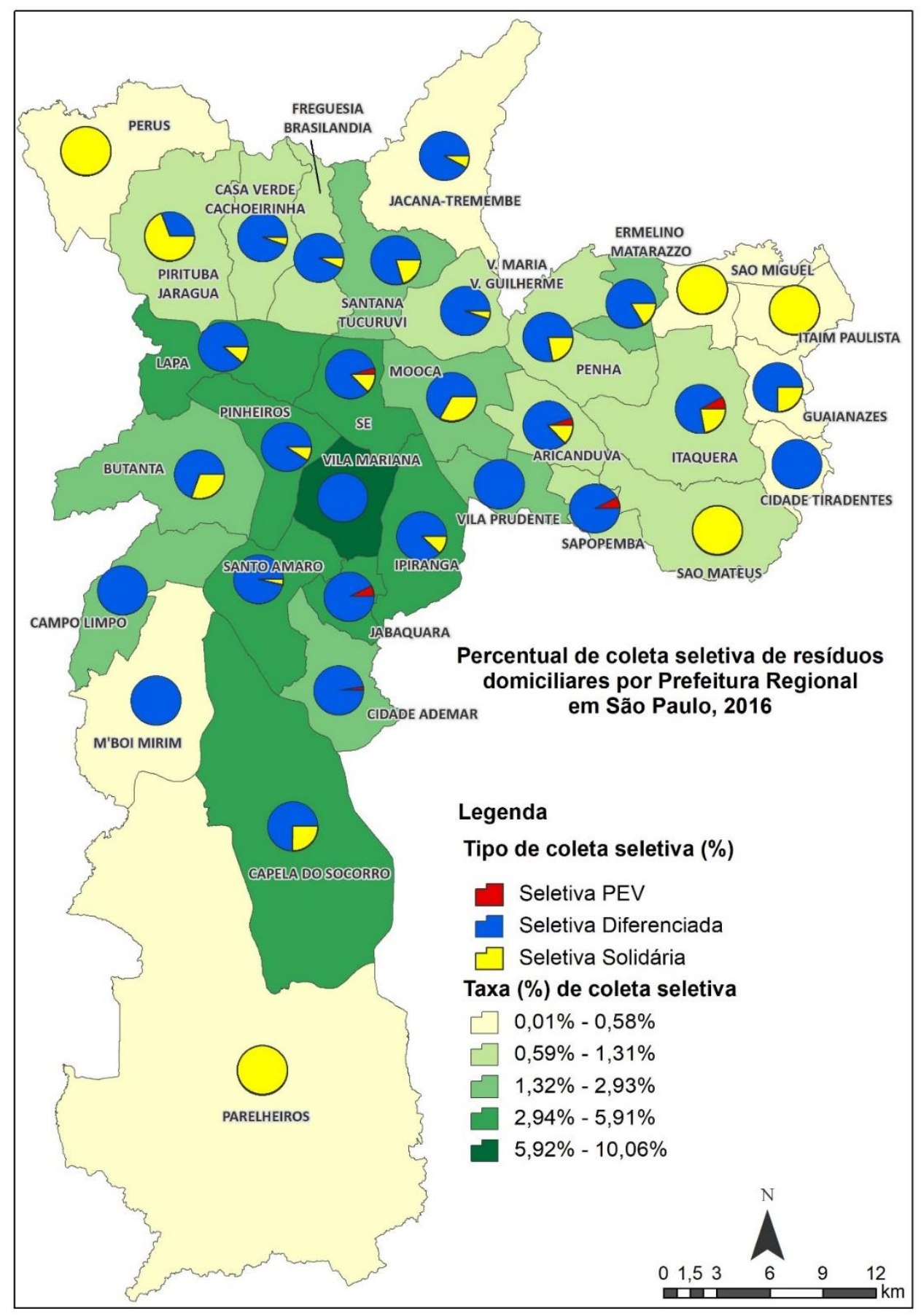

Elaboração: a autora 
Todos os resíduos sólidos urbanos gerados e coletados em São Paulo são enviados para unidades de recepção, tratamento e/ou disposição final de São Paulo apresentadas no Quadro 24.

Quadro 24 Unidades de recepção, triagem e tratamento de resíduos sólidos urbanos em operação em São Paulo, 2017

\begin{tabular}{|l|r|}
\hline Unidade & Quantidade \\
\hline $\begin{array}{l}\text { Central de Tratamento de Resíduos Leste (CTL) e Aterro } \\
\text { Sanitário, Estrada do Sapopemba, 23325 }\end{array}$ & 1 \\
\hline Transbordo Vergueiro, Rua Breno Ferraz do Amaral, 415 B & 1 \\
\hline Transbordo Santo Amaro, Rua Miguel Yunes, 480 & 1 \\
\hline Transbordo Ponte Pequena, Avenida do Estado, 300 & 1 \\
\hline Central Mecanizada Ponte Pequena, Avenida do Estado, 300 & 1 \\
\hline $\begin{array}{l}\text { Central Mecanizada Carolina Maria de Jesus, Av. Miguel } \\
\text { Yunes, 345 }\end{array}$ & 100 \\
\hline Estação de entrega voluntária de inservíveis (ECOPONTO) (1) & 3.811 \\
\hline Posto de entrega voluntária (PEV) (2) & 22 \\
\hline $\begin{array}{l}\text { Cooperativas e Associações de Catadores de resíduos sólidos } \\
\text { conveniadas }\end{array}$ & 20 \\
\hline $\begin{array}{l}\text { Cooperativas e Associações de Catadores de resíduos sólidos } \\
\text { não conveniadas }\end{array}$ & 1 \\
\hline Compostagem Pátio Lapa & \\
\hline
\end{tabular}

Fonte:(1)http://www.prefeitura.sp.gov.br/cidade/secretarias/regionais/amlurb/ecopontos/index.ph $p ? p=4626$.(2)http://www.prefeitura.sp.gov.br/cidade/secretarias/comunicacao/noticias/?p=10681 3

A coleta seletiva em São Paulo não exige segregação na fonte geradora para os resíduos orgânicos sendo estes enviados para aterro sanitário. As únicas iniciativas para a segregação e processamento de compostagem para os resíduos orgânicos são projetos pilotos: (i) Composta São Paulo - composteiras caseiras com minhocas; (ii) pátio de compostagem da Lapa que recebe os resíduos de feiras livres e algumas áreas verdes. 
Somente parte dos resíduos recicláveis ou secos são enviados para triagem (Centrais Mecanizadas ou Cooperativas e Associações). Os resíduos recicláveis dos PEVs e Ecopontos são enviados para triagem. E ainda existem, parte dos resíduos recicláveis, que são coletados por catadores autônomos, cujos dados não estavam disponíveis na AMLURB. A movimentação de resíduos domiciliares está representada no fluxograma de origem e destino dos resíduos (Figura 54).

Conforme pode ser observado no Fluxograma, a AMLURB ainda não estabeleceu a compostagem de resíduos sólidos urbanos de modo centralizado, embora já tenha tido duas usinas de compostagem acelerada, desativas devido impactos ambientais e sanitários. As duas únicas iniciativas de compostagem registradas ainda são projetos pilotos: (i) composta São Paulo composteiras caseiras com vermicompostagem (minhocas) e (ii) pátio de compostagem da Lapa que recebe resíduos de feitas livres e algumas áreas verdes, como projeto piloto. 
Figura 54 Fluxograma da origem e destino dos resíduos sólidos de São Paulo, 2016

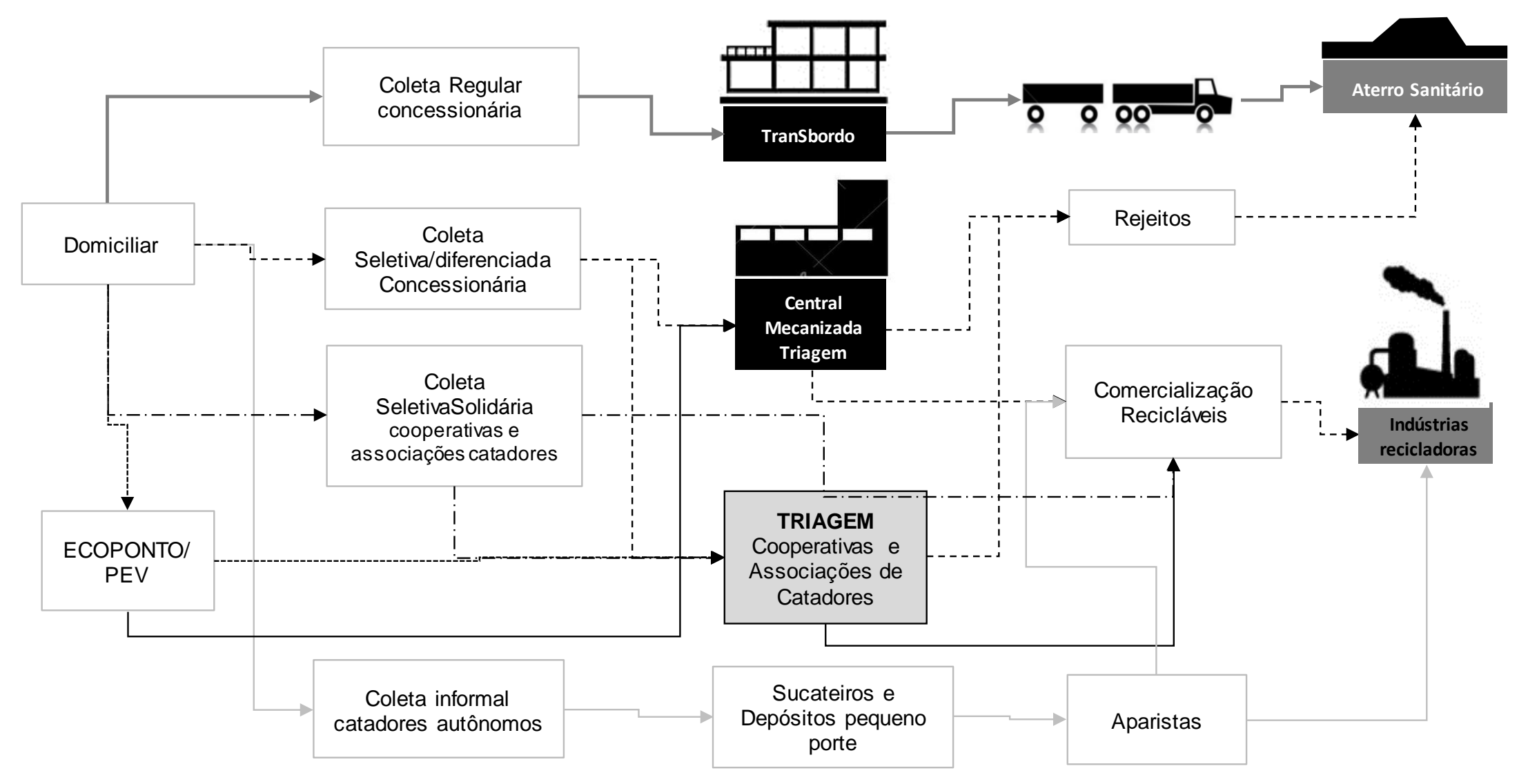

Elaboração: a autora 


\subsubsection{Recuperação de custos dos serviços de coleta regular e/ou seletiva}

Os serviços de coleta regular e coleta seletiva no município de São Paulo não possuem políticas públicas especificas para cobrança pelos serviços prestados aos os geradores que produzem até 200 litros/resíduos/dia. Parte da arrecadação do Imposto Predial e Territorial Urbano (IPTU) é utilizada para a gestão financeira dos serviços de limpeza urbana de São Paulo.

Em 2002, a gestão municipal criou a lei municipal n. 13.478/2002 que instituiu diversas ações para a gestão e o gerenciamento dos resíduos sólidos, inclusive a necessidade de os geradores recolherem uma taxa para os resíduos sólidos domiciliares. Entretanto, em 2005, a referida taxa foi extinta pela lei municipal n. 0 14.125/2005.

Assim, conforme apontado por Wilson et al. (2012) e por Jacobi e Besen (2017), sem a cobrança de uma taxa de resíduos sólidos proporcionais às quantidades geradas, as chances da conscientização da sociedade para minimizar os resíduos descartados na coleta ou destiná-los aos pontos de entregas voluntárias, são menores.

O princípio do pagamento de taxa de resíduos associada as quantidades descartadas de São Francisco e Cidade do Cabo (pay as you throw) foi um dos pontos fundamentais para aumentar a participação da sociedade na segregação de resíduos na fonte geradora, haja vista, que se houver a necessidade de mais contentores de resíduos, além do que é estipulado mensalmente, haverá cobrança extra por parte do prestador de serviços da coleta.

\subsubsection{Programas de Minimização de Resíduos Dispostos em Aterros em São Paulo}

A AMLURB gerencia alguns programas complementares que podem ser considerados como programas de minimização de resíduos sólidos urbanos, 
haja vista que reduzem as quantidades de resíduos dispostos nos aterros sanitários. São eles: Pontos de Entrega Voluntária, Ecopontos, Composta São Paulo, Cata Bagulho e Compostagem Pátio da Lapa.

- Pontos de Entrega Voluntária (PEV)

Os postos de entrega voluntária (PEVs) são contêineres distribuídos em $3.811^{12}$ locais, espalhados pelo município para que os cidadãos depositem, de forma voluntária, seus resíduos sólidos recicláveis/secos, contribuindo assim, para a redução do envio de resíduos para aterramento (Figura 55).

Figura 55 Posto de entrega voluntária de resíduos sólidos recicláveis/secos de São Paulo

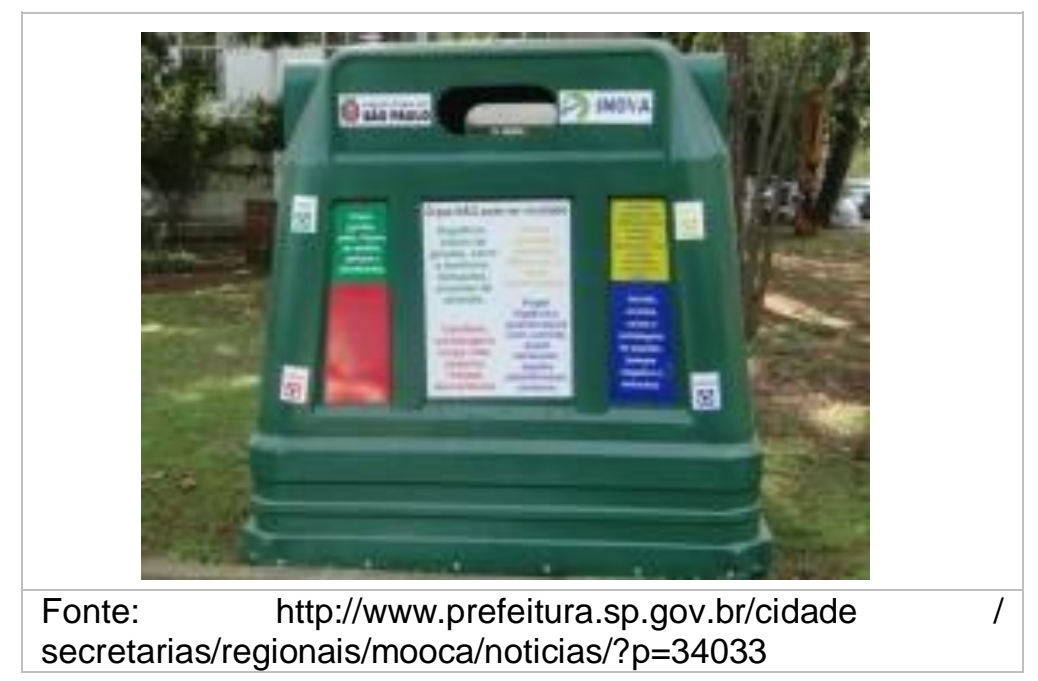

\section{- Ecopontos}

Os Ecopontos também são locais de entrega voluntária de resíduos sólidos gerados pelos cidadãos de São Paulo, nos quais podem descartados: pequenas quantidades de entulhos proveniente de reformas domiciliares (até 1 $\mathrm{m}^{3}$ ), objetos volumosos, podas de jardins e recicláveis secos (Figura 56). As informações obtidas até o momento mencionam que são 100 Ecopontos em operação no munícipio de São Paulo.

${ }^{12}$ Cabe ressaltar que o número de PVEs existentes varia dependendo da data e fonte de informação (concessionárias ou AMLURB) 
Figura 56 Vista parcial da entrada de Ecoponto com sinalização dos materiais recebidos na unidade

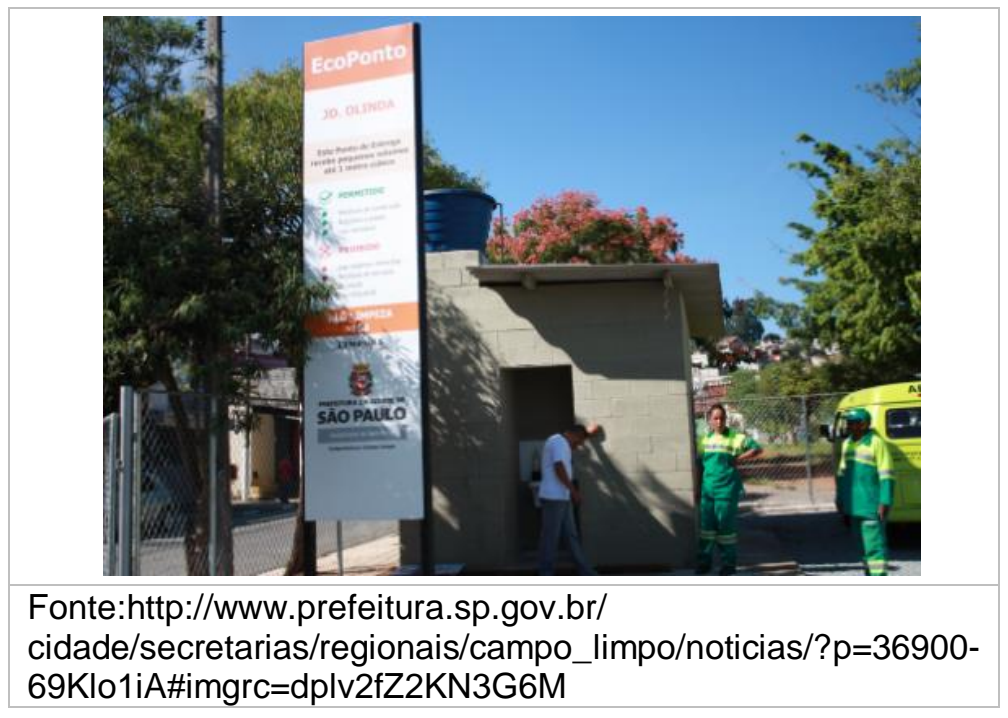

- Composta São Paulo

Este programa foi iniciado como projeto piloto em junho de 2014. Foram doadas 2.006 composteiras caseiras (COMPOSTA SÃO PAULO, 2017), sendo:

O projeto Composta São Paulo é uma iniciativa da Secretaria de Serviços da Prefeitura de São Paulo, por meio da AMLURB, realizado pelas concessionárias de limpeza urbana LOGA e ECOURBIS. Trata-se de uma iniciativa piloto do Programa de Compostagem Doméstica, que é parte do SP Recicla - uma rede de iniciativas para melhor destinação dos resíduos da cidade. A idealização e execução é da Morada da Floresta, empresa referência em compostagem doméstica e empresarial. As pesquisas e estratégias de mobilização são da Blue, consultoria de inteligência social. Acima de tudo, o COMPOSTA SÃO PAULO é das pessoas interessadas em uma cidade e um futuro melhor.

Os principais resultados do programa, obtidos diretamente no site da ONG Morada da Floresta são transcritos a seguir:

Em 40 dias o projeto teve 10.061 inscrições no site;

A entrega das composteiras foi acompanhada de 135 oficinas de capacitação para mais de 5.000 participantes, onde foram apresentadas a teoria e prática do processo de vermicompostagem apoiadas por vídeos e manuais; 
Para monitorar o projeto foram elaborados 5 questionários, um de cadastro, três de acompanhamento e um de desistência;

Os resultados mostram que $89 \%$ diminuíram notavelmente a entrega de resíduos para a coleta;

$97 \%$ dos participantes que responderam à pesquisa (1535 pessoas), se consideram satisfeitos ou muito satisfeitos com a técnica;

A vinculação da prática da compostagem doméstica com participação e responsabilidade cidadã foi fator fundamental para o engajamento da população. Além da novidade na própria técnica de compostagem, a utilização de técnicas contemporâneas de comunicação social, tanto nos meios como em linguagem, trouxe um aspecto de ineditismo no projeto, despertando o desejo de pertencimento ao longo de todo projeto, dos selecionados e também dos não selecionados para receber composteira

COMPOSTA SÃO PAULO

Não foram localizadas informações do andamento e estado atual desde programa.

- Cata Bagulho

Este programa foi criado para minimizar os efeitos dos descartes de objetos volumosos inservíveis em espaços públicos (vias, praças, terrenos baldios, drenagens, etc.). É gerenciado pelas Prefeituras Regionais e ocorre com data previamente definida pelos gestores que, posteriormente, se encarregam de avisar a população beneficiada pelo serviço (Figura 57). 
Figura 57 Caminhão utilizado na operação cata bagulho

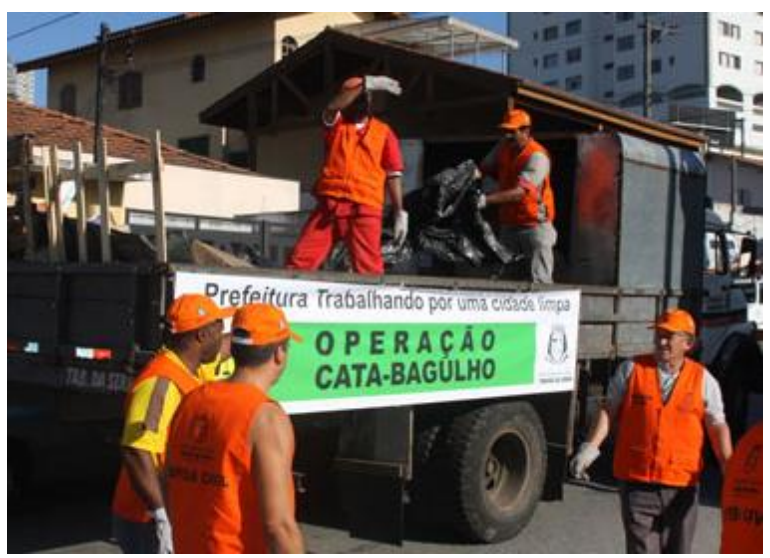

Fonte:http://www.prefeitura.sp.gov.br/cidade/secretaria $\mathrm{s} /$ regionais/guaianases/noticias/? $\mathrm{p}=49882$

- Compostagem Pátio da Lapa

Foi implantado em dezembro de 2015, a compostagem do Pátio da Lapa (Figura 58) que recebe resíduos de feiras livres e podas e processa cerca de 10 toneladas de resíduos sólidos por dia, conforme informação obtida no levantamento de campo junto à AMLURB.

Figura 58 Vista parcial do pátio de compostagem da Lapa

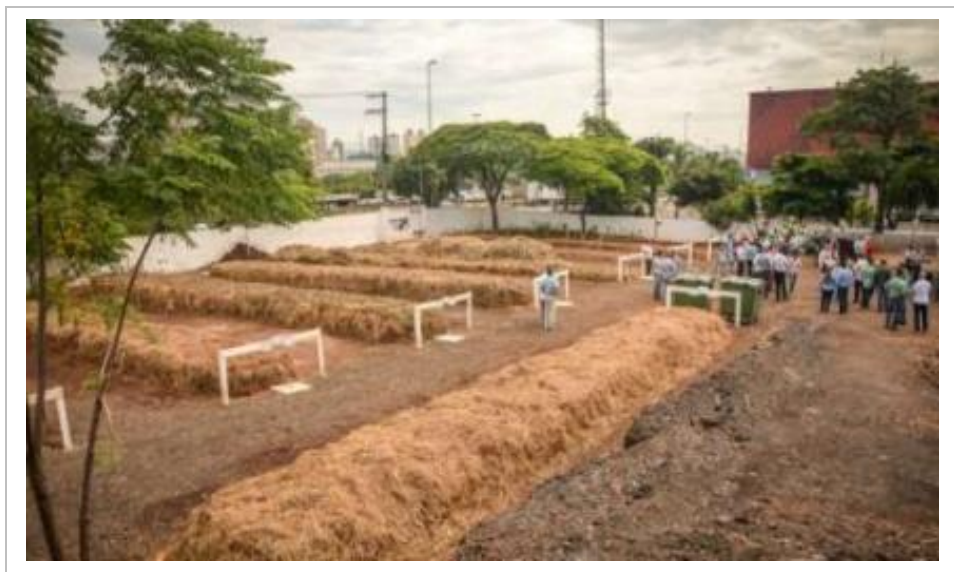

Fonte: Amlurb, 2017

- Outros Programas Não Gerenciados pela AMLURB

No município de São Paulo existem outros programas que estimulam a separação dos resíduos sólidos na fonte geradora e contribuem com a 
diminuição das quantidades de resíduos sólidos destinados a aterros realizados pelo Terceiro Setor e/ou empresas privadas. Entretanto, durante o período desta pesquisa, estes dados não foram sistematizados.

\subsubsection{Políticas Públicas Aplicadas aos Resíduos Sólidos de São Paulo}

As principais políticas públicas existentes (Quadro 25) em São Paulo para aumentar a segregação dos resíduos sólidos urbanos na fonte e as taxas de reciclagem entre 2006 e 2016 foram: (i) a política nacional de resíduos sólidos (PNRS), aprovada em 2010 e (ii) o plano municipal de gestão integrada de resíduos sólidos (PGRS), publicado em 2014.

Quadro 25 Políticas públicas e seus instrumentos para a gestão dos resíduos sólidos de São Paulo, 2018

\begin{tabular}{|c|c|c|}
\hline Ano & Número Instrumento & Política Pública \\
\hline 2002 & $\begin{array}{l}\text { Lei Municipal № } \\
\text { 13.478/2002 alterada } \\
\text { pela Lei Municipal } \\
13.522 / 2003\end{array}$ & $\begin{array}{l}\text { Dispõe sobre a organização do Sistema de } \\
\text { Limpeza Urbana do Município de São Paulo; } \\
\text { cria e estrutura seu órgão regulador; autoriza o } \\
\text { Poder Público a delegar a execução dos } \\
\text { serviços públicos mediante concessão ou } \\
\text { permissão; institui a Taxa de Resíduos Sólidos } \\
\text { Domiciliares - TRSD, a Taxa de Resíduos } \\
\text { Sólidos de Serviços de Saúde - TRSS e a } \\
\text { Taxa de Fiscalização dos Serviços de Limpeza } \\
\text { Urbana - FISLURB; cria o Fundo Municipal de } \\
\text { Limpeza Urbana - FMLU, e dá outras } \\
\text { providências } \\
\text { Dá nova redação a dispositivos e aos Anexos } \\
\text { I, III, IV e VI da Lei no } 13.478\end{array}$ \\
\hline 2005 & $\begin{array}{l}\text { Lei Municipal } \\
14.125 / 2005\end{array}$ & $\begin{array}{l}\text { Extingui a taxa de resíduos sólidos } \\
\text { domiciliares }\end{array}$ \\
\hline 2011 & $\begin{array}{l}\text { Lei Municipal } \\
15.374 / 2011\end{array}$ & $\begin{array}{l}\text { Proibiu a distribuição gratuita de sacolas } \\
\text { plásticas. }\end{array}$ \\
\hline 2012 & $\begin{array}{l}\text { Decreto Municipal № } \\
53.323 / 2012\end{array}$ & $\begin{array}{l}\text { Aprovou o plano municipal de resíduos de } \\
\text { Gestão resíduos sólidos }\end{array}$ \\
\hline 2014 & $\begin{array}{l}\text { Decreto Municipal № } \\
54.991 / 2014\end{array}$ & $\begin{array}{l}\text { Revisou o plano de } 2012 \text { e aprovou o Plano de } \\
\text { Gestão Integrado De Resíduos Sólidos } \\
\text { (PGRS) com validade para o período } 2014\end{array}$ \\
\hline
\end{tabular}




\begin{tabular}{|c|c|c|}
\hline Ano & $\begin{array}{c}\text { Número Instrumento } \\
\text { Leqal }\end{array}$ & Política Pública \\
\hline & & 2033. \\
\hline 2014 & $\begin{array}{l}\text { Decreto Municipal № } \\
55.747 / 14\end{array}$ & $\begin{array}{l}\text { Aprova o programa de educação ambiental e } \\
\text { comunicação social em resíduos sólidos do } \\
\text { município de São Paulo } 2014 / 2033 \text {, bem como } \\
\text { cria o comitê intersecretarial de } \\
\text { implementação do referido programa }\end{array}$ \\
\hline 2016 & $\begin{array}{lcc}\text { Portaria } & \text { № } & 11 \\
\text { SES/AMLURB/2016 }\end{array}$ & $\begin{array}{l}\text { Grupo de Trabalho Multidisciplinar } \\
\text { responsável pela análise das propostas do } \\
\text { Programa de Conscientização Ambiental e } \\
\text { divulgação dos serviços a serem apresentados } \\
\text { pelas Concessionárias de serviços divisíveis } \\
\text { de limpeza urbana }\end{array}$ \\
\hline
\end{tabular}
influenciaram as ações de gestão e gerenciamento, a Política Estadual de Resíduos Sólidos (Lei Estadual № 12.300/2006) e Política Nacional De Resíduos Sólidos (Lei Federal n. 12.306/10 PNRS).

As principais metas traçadas no PGIRS (ALMURB, 2014) estão apresentadas no Quadro 26 e, conforme pode ser observado, o atendimento às mesmas foi cumprido parcialmente.

Quadro 26 Metas previstas e realizadas do PGIRS para São Paulo, abril 2018

\begin{tabular}{|c|c|c|}
\hline Meta Prevista (1) & $\begin{array}{l}\text { Análise do Atendimento da Meta em } \\
\qquad 2018(2)\end{array}$ & Resultado \\
\hline $\begin{array}{l}\text { Processar } 3.000 \text { t/dia resíduos } \\
\text { secos/recicláveis }\end{array}$ & $\begin{array}{l}\text { 2014: } 165,99 \text { t/dia resíduos coleta } \\
\text { seletiva } \\
\begin{array}{l}\text { 2015: } 237,93 \\
\text { seletiva }\end{array} \\
\begin{array}{l}\text { 2016: } 231,92 \\
\text { seletiva }\end{array}\end{array}$ & $\begin{array}{l}\text { Não } \\
\text { atendida } \\
\text { Não } \\
\text { atendida } \\
\text { Não } \\
\text { atendida }\end{array}$ \\
\hline $\begin{array}{l}\text { Processar } 1.300 \text { t/dia em unidades de } \\
\text { Tratamento Mecânico Biológico }\end{array}$ & $\begin{array}{l}\text { Não implantada unidade de tratamento } \\
\text { mecânico biológica até abril de } 2018\end{array}$ & $\begin{array}{l}\text { Não } \\
\text { atendida }\end{array}$ \\
\hline $\begin{array}{l}\text { Ampliação da capacidade produtiva de } \\
\text { centrais de triagem já implantadas em } \\
\text { pequenas áreas (10 unidades em } \\
\text { espaços públicos cedidos, com } \\
\text { capacidade de processamento de } 390 \\
\text { toneladas por dia em conjunto com } \\
\text { outras cooperativas contratadas) }\end{array}$ & Não implantado até abril de 2018 & $\begin{array}{l}\text { Não } \\
\text { atendida }\end{array}$ \\
\hline
\end{tabular}




\begin{tabular}{|c|c|c|}
\hline Meta Prevista (1) & $\begin{array}{l}\text { Análise do Atendimento da Meta em } \\
\qquad 2018(2)\end{array}$ & Resultado \\
\hline $\begin{array}{l}\text { Instalação de centrais de } \\
\text { processamento da coleta seletiva de } \\
\text { resíduos secos }(4 \text { unidades } \\
\text { distribuídas regionalmente, com } \\
\text { capacidade para } 1.000 \text { toneladas por } \\
\text { dia) }\end{array}$ & Não implantado até abril de 2018 & $\begin{array}{l}\text { Não } \\
\text { atendida }\end{array}$ \\
\hline $\begin{array}{l}\text { Instalação de unidades de tratamento } \\
\text { mecânico biológico (4 unidades } \\
\text { distribuídas regionalmente, para } 1.300 \\
\text { toneladas por dia) }\end{array}$ & Não implantado até abril de 2018 & $\begin{array}{l}\text { Não } \\
\text { atendida }\end{array}$ \\
\hline $\begin{array}{l}\text { Universalização da coleta seletiva de } \\
\text { resíduos secos com atendimento de } \\
\text { todo o território de cada distrito da } \\
\text { cidade, precedida de campanhas: } \\
\text { 2013: } \\
0 \text { distritos; 2014: } \\
40 \text { distritos; } \\
\text { 2015: } 54 \text { distritos; } \\
\text { 2016: } 96 \text { distritos. } \\
\text { E a partir de 2017, manter a coleta } \\
\text { seletiva de resíduos secos nos } 96 \\
\text { distritos do município (PGIRS, 2014: } \\
\text { 108) }\end{array}$ & $\begin{array}{l}\text { A coleta seletiva não foi universalizada } \\
\text { pois ainda existem partes do território } \\
\text { municipal cujas quantidades de coleta } \\
\text { seletiva registrada são inferiores a } \\
0,5 \% \text { do total coletado seletivamente } \\
\text { dos resíduos domiciliares: } \\
\text { Parelheiros: } 0,01 \% \\
\text { Perus: } 0,05 \% \\
\text { M Boi Mirim: } 0,18 \% \\
\text { Itaim Paulista: } 0,36 \% \\
\text { Guaianases: } 0,36 \% \\
\text { Os dados dos setores de coleta são } \\
\text { registrados pelo SISCOR por } \\
\text { Prefeituras Regionais e não pelos } \\
\text { limites dos Distritos }\end{array}$ & $\begin{array}{l}\text { mente } \\
\text { a }\end{array}$ \\
\hline $\begin{array}{l}\text { Adesão dos domicílios à coleta } \\
\text { seletiva de resíduos secos precedida } \\
\text { de campanha de comunicação (\% de } \\
\text { domicílios atendidos) Universo = } 3,53 \\
\text { milhões de domicílios: } 2014: 33 \% \text { dos } \\
\text { domicílios: } 2015: 36 \% \text { dos domicílios; } \\
\text { 2016: } 40 \% \text { dos domicílios; } 2017: 42 \\
\% \text { dos domicílios }\end{array}$ & $\begin{array}{l}\text { Adesão existe, mas ainda é incipiente } \\
\text { A coleta seletiva (diferenciada e/ou } \\
\text { solidária) não abrange todos os } \\
\text { domicílios formais }\end{array}$ & da \\
\hline $\begin{array}{l}\text { Centrais de Processamento dos } \\
\text { Resíduos da Coleta Seletiva de } \\
\text { Secos: Zona Sul, posição } 1 \text { (área } \\
\text { contígua ao Aterro Santo Amaro); } \\
\text { Zona Leste, posição } 3 \text { (área contígua } \\
\text { ao CTL); Zona Norte, posição } 6 \text { (área } \\
\text { no Parque Novo Mundo); Zona Oeste, } \\
\text { posição } 5 \text { (área no Transbordo Ponte } \\
\text { Pequena) }\end{array}$ & $\begin{array}{l}\text { Zona Sul: implantada CMT Maria } \\
\text { Carolina de Jesus } \\
\text { Zona Leste: não implantada } \\
\text { Zona Norte: não implantada } \\
\text { Zona Oeste: implantada CMT Ponte } \\
\text { Pequena }\end{array}$ & $\begin{array}{l}\text { Parcialmente } \\
\text { atendida }\end{array}$ \\
\hline
\end{tabular}

Nota: (1) PGIRS, 2014. Calculado a partir das quantidades anuais da Tabela 18. 


\section{COMPARAÇÃO E DISCUSSÃO DOS CASOS ESTUDADOS}

A partir dos dados quantitativos e qualitativos coletados em campo, bem como, com a revisão bibliográfica foi possível construir uma análise qualitativa dos resultados encontrados para as três cidades, conforme apresentado na sequência.

\subsection{Variáveis Analisadas}

A fim de revelar as diferentes dimensões dos municípios estudados, apresenta-se (Tabela 22) algumas variáveis que influenciam a geração dos resíduos sólidos.

Os dados populacionais refletem diretamente nas quantidades de resíduos sólidos urbanos gerados, mesmo que, em âmbito mundial, tenha sido constatado que o aumento das quantidades de resíduos sólidos tem sido maior que as taxas de crescimento populacional (WORLD BANK, 2012).

O número de domicílios e o tipo (unifamiliar, multifamiliar, ocupações irregulares, dentre outros) também são fatores importantes para o bom funcionamento dos sistemas de gestão e gerenciamento de resíduos sólidos, uma vez que ao se padronizar por exemplo, horários de coletas, forma e capacidade de contentores de resíduos, bem como, equipamentos mecanizados, os tipos e as quantidades de domicílios devem ser considerados. A renda per capita também influencia os padrões de consumo e, consequentemente, os tipos de resíduos descartados: regiões mais ricas em termos de renda per capita, tem maior tendência de produzirem mais recicláveis em virtude do maior poder de consumo e da aquisição de maior quantidade de produtos industrializados e embalagens. $\mathrm{E}$, consequentemente, ter maiores taxas de coleta seletiva de resíduos, caso exista este serviço. Assim São Francisco, com maior renda per capita, maior percentual de materiais recicláveis $(42,30 \%)$ em termos de composição gravimétrica, possui maior taxa 
de coleta seletiva ${ }^{13}$ (Tabela 23), quando comparado a Cidade do Cabo e São Paulo. Entretanto, conforme apresentado nos itens a seguir, além da variável renda, as políticas públicas implantadas influenciam as taxas de coleta seletiva.

Tabela 22 População e renda per capita nos municípios estudados

\begin{tabular}{cccc}
\hline Variável & São Francisco & Cidade do Cabo & São Paulo \\
\hline \multirow{3}{*}{ População Total } & $776.733(2000)(1)$ & $2.892 .243(2001)(2)$ & $10.434 .252(2000)(4)$ \\
\cline { 2 - 4 } & $805.235(2010)(1)$ & $3.740 .025(2011)(2)$ & $11.253 .503(2010)(4)$ \\
\cline { 2 - 4 } & $870.887(2016)(1)$ & $4.004 .793(2016)(3)$ & $12.106 .920(2017)(4)$ \\
\hline $\begin{array}{c}\text { Renda per } \\
\text { capita }\end{array}$ & $\begin{array}{c}\text { USD } 55.567,00(5) \\
(2016)\end{array}$ & $\begin{array}{c}\text { USD 7.504,30 (6) } \\
(2016)\end{array}$ & USD 13.399,62 (7) \\
\end{tabular}

Fonte: (1) https://www.census.gov/quickfacts/fact/table/sanfranciscocountycalifornia/INC110216.

(2)http://resource.capetown.gov.za/documentcentre/Documents/Maps\%20and\%20statistics/201

1_Census_Cape_Town_Profile.pdf.(3)https://www.westerncape.gov.za/assets/departments/trea sury/Documents/Socio-economic-profiles/2016/City-of-Cape-

Town/city_of_cape_town_2016_socio-economic_profile_sep-

Ig.pdf.(4)https://cidades.ibge.gov.br/brasil/sp/sao-

paulo/panorama.(5)https://www.census.gov/quickfacts/fact/table/sanfranciscocitycalifornia,sanfra nciscocountycalifornia/INC910216. (6) https://tradingeconomics.com/south-africa/gdp-per-capita. (7) http://www.perfil.seade.gov.br/\# e câmbio médio para ano 2016 de 1 USD $=R \$ 3,40$.

Conforme pode ser observado na Tabela 23, São Paulo é o maior gerador de resíduos sólidos e possui a menor taxa de coleta seletiva, quando comparado aos demais municípios.

\footnotetext{
${ }^{13}$ Ressalta-se que para São Francisco e Cidade do Cabo, a denominação das administrações municipais para a coleta seletiva é recuperação de resíduos e minimização de resíduos, respectivamente.
} 
Tabela 23 Total de resíduos sólidos urbanos e taxa de coleta seletiva

\begin{tabular}{|cccccccc}
\hline & \multicolumn{2}{c}{ São Francisco (1) } & \multicolumn{2}{c}{ Cidade do Cabo (2) } & \multicolumn{2}{c}{ São Paulo (3) } \\
\cline { 2 - 8 } Ano & $\begin{array}{c}\text { Total de } \\
\text { Resíduos } \\
\text { Sólidos } \\
\text { Urbanos } \\
\text { (t) }\end{array}$ & $\begin{array}{c}\text { Taxa de } \\
\text { Coleta } \\
\text { Seletiva } \\
(\%)\end{array}$ & $\begin{array}{c}\text { Total de } \\
\text { Resíduos } \\
\text { Sólidos } \\
\text { Urbanos } \\
\text { (t) }\end{array}$ & $\begin{array}{c}\text { Taxa de } \\
\text { Coleta } \\
\text { Seletiva } \\
\text { (\%) }\end{array}$ & $\begin{array}{c}\text { Total de } \\
\text { Resíduos } \\
\text { Sólidos } \\
\text { (Urbanos t) }\end{array}$ & $\begin{array}{c}\text { Taxa de } \\
\text { Coleta } \\
\text { Seletiva } \\
(\%)\end{array}$ \\
\hline $\mathbf{2 0 0 6}$ & 2.033 .980 & $70 \%$ & $\ldots$ & $\ldots$ & $5.312 .902,56$ & $0,43 \%$ \\
\hline $\mathbf{2 0 0 7}$ & 2.100 .943 & $72 \%$ & 2.712 .805 & $\ldots$ & $5.599 .850,77$ & $0,54 \%$ \\
\hline $\mathbf{2 0 0 8}$ & 2.142 .671 & $77 \%$ & 1.997 .156 & $\ldots$ & $5.905 .153,56$ & $0,69 \%$ \\
\hline $\mathbf{2 0 0 9}$ & 1.983 .934 & $78 \%$ & 1.813 .713 & $\ldots$ & $6.403 .554,51$ & $0,54 \%$ \\
\hline $\mathbf{2 0 1 0}$ & 2.000 .214 & $80 \%$ & 1.813 .713 & $\ldots$ & $5.930 .517,29$ & $0,56 \%$ \\
\hline $\mathbf{2 0 1 1}$ & 2.154 .476 & $82 \%$ & 1.881 .967 & $10 \%$ & $5.622 .013,59$ & $0,79 \%$ \\
\hline $\mathbf{2 0 1 2}$ & 2.255 .812 & $83 \%$ & 1.975 .254 & $14 \%$ & $6.429 .261,64$ & $0,89 \%$ \\
\hline $\mathbf{2 0 1 3}$ & 2.672 .124 & $85 \%$ & 2.345 .733 & $9 \%$ & $6.009 .028,04$ & $1,11 \%$ \\
\hline $\mathbf{2 0 1 4}$ & 2.875 .078 & $84 \%$ & $2.471,432$ & $8 \%$ & $5.234 .411,31$ & $1,16 \%$ \\
\hline $\mathbf{2 0 1 5}$ & $\ldots$ & $\ldots$ & 2.388 .256 & $15 \%$ & $5.527 .293,96$ & $1,57 \%$ \\
\hline $\mathbf{2 0 1 6}$ & $\ldots$ & $\ldots$ & 2.537 .483 & $27 \%$ & $5.230 .713,63$ & $1,62 \%$ \\
\hline
\end{tabular}

Fonte: (1) San Francisco Department of the Environment. Commercial Zero Waste Coordinator.

(2) 3rd Generation IWM Plan, 2016; Western Cape Integrated Waste Management Plan 20172022, 2016; Levantamento de campo, 2018. (3) SISCOR, 2017.

Nota: (...) Dado não disponível.

Conforme pode ser observado na Tabela 23, São Francisco é o município com a menor população (menos de 1 milhão de habitantes), maior renda "per capita" anual, registrou cerca de 3 milhões de toneladas de resíduos nos últimos anos e possui a maior taxa de coleta seletiva (mais de $80 \%$ ). A Cidade do Cabo, com cerca de 4 milhões de habitantes, coletou cerca 2,5 milhões de toneladas de resíduos, e tem taxa de coleta seletiva da ordem de $30 \%$. São Paulo, com cerca de 12 milhões de habitantes, coletou aproximadamente 5 milhões de toneladas de resíduos e registrou taxa de coleta seletiva da ordem de $1,6 \%$.

A comparação das variáveis estudadas para as coletas seletivas dos 3 municípios (Quadro 27) demostra que a oferta do serviço para todo território, especialmente nas áreas de maior geração de resíduos é um fator preponderante para o aumento das taxas de coleta seletiva. Entretanto, no caso 
da frequência da coleta seletiva, esta não é uma variável essencial para o aumento da taxa, desde que, exista padronização do armazenamento dos resíduos triados em recipientes (contentor) para reter os materiais no intervalo entre os dias de coleta.

No caso da cobrança de taxa de coleta dos resíduos, a disponibilização de contentores é essencial para a administração municipal cobrar proporcionalmente dos geradores pelas quantidades descartadas, assim como é realizado em São Francisco e na Cidade do Cabo.

Quadro 27 Comparação das variáveis da coleta seletiva nos municípios estudados

\begin{tabular}{|c|c|c|c|}
\hline \multirow{2}{*}{$\begin{array}{l}\text { Coleta Seletiva } \\
\text { (segregação na fonte) }\end{array}$} & \multicolumn{3}{|c|}{ Município } \\
\hline & São Francisco & Cidade do Cabo & São Paulo \\
\hline $\begin{array}{l}\text { Abrangência territorial da } \\
\text { coleta com segregação de } \\
\text { resíduos }\end{array}$ & $100 \%$ & $\begin{array}{l}\text { Parcial, pulverizada em } \\
\text { várias regiões }\end{array}$ & $\begin{array}{l}\text { Parcial, concentrada } \\
\text { em algumas regiões }\end{array}$ \\
\hline $\begin{array}{l}\text { Tipos de resíduos } \\
\text { coletados }\end{array}$ & $\begin{array}{l}\text { orgânicos, } \\
\text { recicláveis, } \\
\text { rejeitos }\end{array}$ & orgânicos e recicláveis & recicláveis \\
\hline Frequência da coleta & 2 vezes/semana & $1 \mathrm{vez} / \mathrm{semana}$ & $1 \mathrm{vez} /$ semana \\
\hline $\begin{array}{l}\text { Regularidade: ininterrupta } \\
\text { desde sua criação }\end{array}$ & $\operatorname{sim}$ & $\operatorname{sim}$ & não \\
\hline $\begin{array}{l}\text { Eficiência: proporciona o } \\
\text { reaproveitamento e/ou } \\
\text { reciclagem tipos de } \\
\text { resíduos }\end{array}$ & $\begin{array}{l}3 \text { tipos de } \\
\text { resíduos } \\
\text { (secos, } \\
\text { orgânicos, } \\
\text { rejeito) }\end{array}$ & $\begin{array}{l}2 \text { tipos de resíduos } \\
\text { (secos e orgânicos) }\end{array}$ & $\begin{array}{l}1 \text { tipos de resíduos } \\
\text { (secos) }\end{array}$ \\
\hline $\begin{array}{l}\text { Potencializa os benefícios } \\
\text { ambientais e valorização } \\
\text { dos resíduos }\end{array}$ & $\begin{array}{l}\text { desvia mais de } \\
84 \% \text { dos } \\
\text { resíduos do } \\
\text { aterramento }\end{array}$ & $\begin{array}{l}\text { desvia } 27 \% \text { dos } \\
\text { resíduos do } \\
\text { aterramento }\end{array}$ & $\begin{array}{l}\text { desvia menos de } \\
\text { 1,62\% dos resíduos } \\
\text { do aterramento }\end{array}$ \\
\hline $\begin{array}{l}\text { Incorporadora: permite a } \\
\text { participação de diversos } \\
\text { atores na coleta }\end{array}$ & $\begin{array}{l}\text { empresas de } \\
\text { grande porte }\end{array}$ & $\begin{array}{l}\text { empresas de grande e } \\
\text { pequeno porte, ONGs, } \\
\text { associações de } \\
\text { moradores }\end{array}$ & $\begin{array}{c}\text { empresas de grande, } \\
\text { cooperativas e } \\
\text { associações } \\
\text { catadores }\end{array}$ \\
\hline
\end{tabular}


A regularidade dos serviços de coleta seletiva (Quadro 27), sem interrupções, também é um fator importante para manter a participação constante da população e, neste caso, inclui-se também, a devida comunicação social em diferentes mídias, que deve ser realizada pelo poder público e não somente pelas empresas concessionárias dos serviços. Em São Francisco e na Cidade do Cabo, as administrações municipais promovem campanhas de divulgação da existência dos serviços de coleta seletiva e, segundo informações obtidas durante o levantamento de campo, os setores responsáveis consideram que a divulgação é um elemento fundamental para manter a população motivada. Para São Paulo, foi obtida informação que a responsabilidade da divulgação da existência do serviço de coleta seletiva é das concessionárias e, o programa de educação ambiental para coleta seletiva não foi implantado.

O aumento das taxas de coleta seletiva contribui com a melhoria da saúde pública e do meio ambiente uma vez que diminui a poluição dos recursos naturais causada pelo manejo inadequado, reduz as emissões dos gases do Efeito Estufa (Metano e Dióxido de Carbono), promove ambientes mais saudáveis para trabalhadores do setor, reduz da exploração de recursos naturais, diminui o consumo de energia elétrica e do uso de combustíveis fósseis, aumenta a geração de empregos, incentiva a economia circular, contribuindo assim, com a sustentabilidade. Neste sentido, a gestão dos resíduos sólidos com coleta seletiva em São Francisco é a mais emblemática: $84 \%$, quando comparada à Cidade do Cabo (27\%), ao passo que São Paulo $(1,62 \%)$, necessita implantar sua taxa de coleta (Quadro 27).

Quando a coleta seletiva municipal incorpora (Quadro 27) prestadores de serviço de diversos portes empresariais (pequeno médio e grande) e organizações do terceiro setor (ONGs, associações de moradores, cooperativas e associações de catadores), amplia sua extensão territorial pois áreas não atrativas para empresas maiores devido custos operacionais e logística de 
transporte, passam a ser atendidas por empresas e organizações de menor porte. Assim, consequentemente, a diversificação do porte e tipo de prestadores de serviços também gera maiores oportunidades de empregos. Neste enfoque a gestão da coleta seletiva na Cidade do Cabo é mais incorporadora, quando comparada a São Francisco e São Paulo.

As políticas públicas dos municípios estudados que influenciaram taxas de coleta seletiva dos municípios estuados no período 2006 a 2016 estão sistematizadas no Quadro 28.

A recuperação de custos por meio de tarifa de coleta de resíduos é uma política pública fundamental para manter a regularidade dos serviços, bem como, para estimular o gerador a descartar as quantidades de resíduos equivalentes ao valor da taxa, especialmente quando a cobrança é eficiente para contentores extras para armazenamento de mais resíduos. Este método funciona para os municípios de São Francisco e Cidade do Cabo que possuem as coletas contenerizadas. São Paulo não aplica taxa de coleta de resíduos para os geradores que produzem até 200 litros/resíduos/dia (Quadro 28).

Quadro 28 Comparação das variáveis de políticas públicas nos municípios estudados

\begin{tabular}{|l|c|c|c|}
\hline \multicolumn{1}{|c|}{ Políticas Públicas } & \multicolumn{3}{|c|}{ Município } \\
\cline { 2 - 4 } $\begin{array}{l}\text { Recuperação de } \\
\text { custos/taxa de resíduos }\end{array}$ & $\begin{array}{c}\text { São Francisco } \\
\text { pagamento on line } \\
\text { direto para prestador } \\
\text { de serviço }\end{array}$ & $\begin{array}{c}\text { Sim } \\
\text { pagamento on line } \\
\text { para Administração } \\
\text { Municipal }\end{array}$ & não Paulo \\
\hline $\begin{array}{l}\text { Obrigatoriedade de } \\
\text { segregação na fonte } \\
\text { geradora por instrumento } \\
\text { legal no município }\end{array}$ & sim & sim & não \\
\hline $\begin{array}{l}\text { Planos e programas } \\
\text { claros com metas e } \\
\text { disponíveis para consulta } \\
\text { pública }\end{array}$ & sim & sim & não \\
\hline $\begin{array}{l}\text { Programas } \\
\text { complementares de } \\
\text { reutilização e reciclagem }\end{array}$ & 19 programas & 5 programas & 5 programas \\
\hline
\end{tabular}




\begin{tabular}{|c|c|c|c|}
\hline \multirow{2}{*}{ Políticas Públicas } & \multicolumn{3}{|c|}{ Município } \\
\hline & São Francisco & Cidade do Cabo & São Paulo \\
\hline Divulgação & $\begin{array}{l}\text { Campanhas } \\
\text { publicitárias de TV; } \\
\text { vídeos disponíveis } \\
\text { em redes sociais; } \\
\text { material didático } \\
\text { disponível; oficina } \\
\text { para artistas } \\
\text { utilizarem resíduos } \\
\text { Canais de } \\
\text { comunicação e } \\
\text { formulários on line de } \\
\text { responsabilidade da } \\
\text { Administração } \\
\text { Municipal } \\
\text { Website específico } \\
\text { com detalhamento da } \\
\text { segregação de } \\
\text { materiais }\end{array}$ & $\begin{array}{l}\text { Vídeos disponíveis em } \\
\text { redes sociais; material } \\
\text { didático disponível; } \\
\text { Canais de } \\
\text { comunicação e } \\
\text { formulários on line sob } \\
\text { responsabilidade da } \\
\text { Administração } \\
\text { Municipal } \\
\text { Website específico } \\
\text { para orientação dos } \\
\text { locais de entrega de } \\
\text { resíduos e horários } \\
\text { gerenciado pela } \\
\text { Administração } \\
\text { Municipal }\end{array}$ & $\begin{array}{l}\text { Canal de } \\
\text { comunicação } \\
\text { (156) para } \\
\text { todos os } \\
\text { assuntos } \\
\text { municipais } \\
\text { Website das } \\
\text { concessionárias } \\
\text { para divulgação } \\
\text { da abrangência } \\
\text { da coleta } \\
\text { seletiva; } \\
\text { atualização } \\
\text { precária }\end{array}$ \\
\hline
\end{tabular}

Juntamente com a recuperação de custos, a obrigatoriedade legal da segregação na fonte geradora também é uma variável estruturante para garantir melhores taxas de coleta seletiva (Quadro 28).

Em São Paulo não existe a obrigatoriedade legal municipal para a segregação ao passo que em São Francisco e na Cidade do Cabo, este é um requisito das políticas públicas implantadas. Em São Paulo, segundo informações obtidas durante as entrevistas, além da ausência de obrigatoriedade, a inexistência de um setor na AMLURB que faz a gestão de programas de educação ambientais focados nas orientações da coleta seletiva, bem como, inexistências de campanhas publicitárias em massa para divulgação da necessidade de participação dos munícipes na segregação na fonte.

Particularmente em São Francisco, a fiscalização é rigorosa, contando inclusive com fiscais que inspecionam os contentores dos domicílios, a fim de verificar se o gerador está fazendo a segregação correta. Associado aos aspectos da obrigatoriedade da segregação dos resíduos na fonte, em São Francisco, segundo informações obtidas nas entrevistas de campo, dois fatores corroboram com a elevada taxa de coleta seletiva: (i) grande variedade de 
material didático (vídeos, panfletos, cartilhas digitais, cartazes eletrônicos, etc.) disponível nas redes sociais e endereços eletrônicos oficiais explicando à população, a necessidade de separação dos resíduos; (ii) constantes campanhas nos meios de comunicação (televisão, rádio, mídias sociais) para separação (Quadro 28). Bringhenti e Günther (2011) em seu estudo sobre a coleta seletiva no município de Vitória/Espírito Santo, também apontaram que o resultado da participação da população na segregação dos resíduos está associado a regularidade do funcionamento da coleta implantada e sua eficiência, estratégias de marketing para sensibilização e motivação da população, são fundamentais para o sucesso da segregação dos resíduos na fonte geradora.

$\mathrm{Na}$ Cidade do Cabo, a fiscalização é reduzida e o fator primordial para a segregação dos resíduos está mais associada a obrigatoriedade legal para todas as classes sociais em termos de renda (alta, média e baixa) e, em segundo lugar, para as famílias mais pobres, a segregação propicia uma complementação da renda, conforme informações obtidas nas entrevistas do levantamento de campo. Também foi considerado como terceiro fator importante, as ações educativas de segregação dos resíduos existentes em escolas para crianças e adolescentes que complementam as estratégias da política pública para coleta seletiva (Quadro 28).

Outra ação de gerenciamento de resíduos importante para taxa de coleta seletiva que compõem as políticas públicas de São Francisco e da Cidade do Cabo são os programas complementares à coleta porta a porta. Estes programas permitem que outros tipos de resíduos, especialmente os volumosos e perigosos sejam triados e sejam desviados do aterramento.

Conforme pode ser observado na Figura 59, São Francisco já executava políticas públicas para gestão dos resíduos sólidos focadas na valorização dos resíduos, desde o final da década de 1990, o que rendeu uma taxa de coleta seletiva da ordem de $70 \%$ já no início do anos 2000: (i) desvio dos resíduos de 
aterros sanitários e (ii) execução de projeto piloto que, posteriormente, foi expandido para toda o município. A política pública da Responsabilidade Estendida do Produtor, a segregação de três tipos de resíduos, a obrigatoriedade do uso de materiais biodegradáveis em embalagens e forte liderança política da administração municipal e implantação de programas complementares de segregação de resíduos, incluindo escolas e eventos, contribuíram para que São Francisco alcançasse $80 \%$ de taxas de coleta seletiva a partir de 2010 (USEPA, 2018).

A partir de 2010, a revisão da política pública de Responsabilidade Estendida do Produtor que determinou o gerenciamento do ciclo de vida dos produtos e garantiu incentivos financeiros sob a forma de descontos na taxa de resíduos, contribuíram para aumentar o reaproveitamento dos resíduos.

Segundo a USEPA (2018), dois fatores também contribuíram com o sucesso das políticas públicas de gestão dos resíduos focado na meta Resíduo Zero: (i) a revisão dos valores das taxas de resíduos realizada de 5 em 5 anos para que sejam justas e razoáveis e (ii) a supervisão de um único contrato de resíduos simplificou a gestão do pública.

$\mathrm{Na}$ Cidade do Cabo, a política pública que impulsionou a taxa de coleta seletiva foi a obrigatoriedade de segregação dos resíduos na fonte geradora criada em 2011 (Figura 59). Apesar de menor quantidade de políticas públicas de reaproveitamento, quando comparado a São Francisco, a administração municipal conseguiu elaborar e executar planos integrados de resíduos e suas respectivas metas, especialmente porque os recursos arrecadados com a taxa de coleta de resíduos são gerenciados pelo Departamento de Resíduos Sólidos e permitem ajustar ações versus recursos financeiros arrecadados. Além deste fator, a implantação de programas complementares previstos nos planos de resíduos (drop off's, compostagem, recompra de materiais recicláveis) e a diversificação dos prestadores de serviços (diversos porte de empresas de resíduos, ONGs e associações) completam o conjunto de ações implantadas, 
independentemente de vertentes políticas ao longo do período de 2006 a 2016 que subsidiam taxa de coleta seletiva em 27\% para 2016.

As políticas públicas para gestão integrada dos resíduos sólidos de São Paulo não contemplam a obrigatoriedade da segregação dos resíduos na fonte geradora tão pouco, a recuperação de custos por meio de taxas de coleta (Figura 59). O PGIRS como política pública previu metas para expandir a coleta seletiva para todo o território municipal, entretanto, conforme apresentado na Tabela 18, pode-se concluir que esta meta não foi alcançada pois em 2016 , foram coletados seletivamente $1,62 \%$ do total de resíduos sólidos urbanos. Neste sentido, as políticas públicas de São Paulo ainda são incipientes, apesar da PNRS. 
Figura 59 Políticas públicas implantadas ao longo do tempo nos municípios estudados.

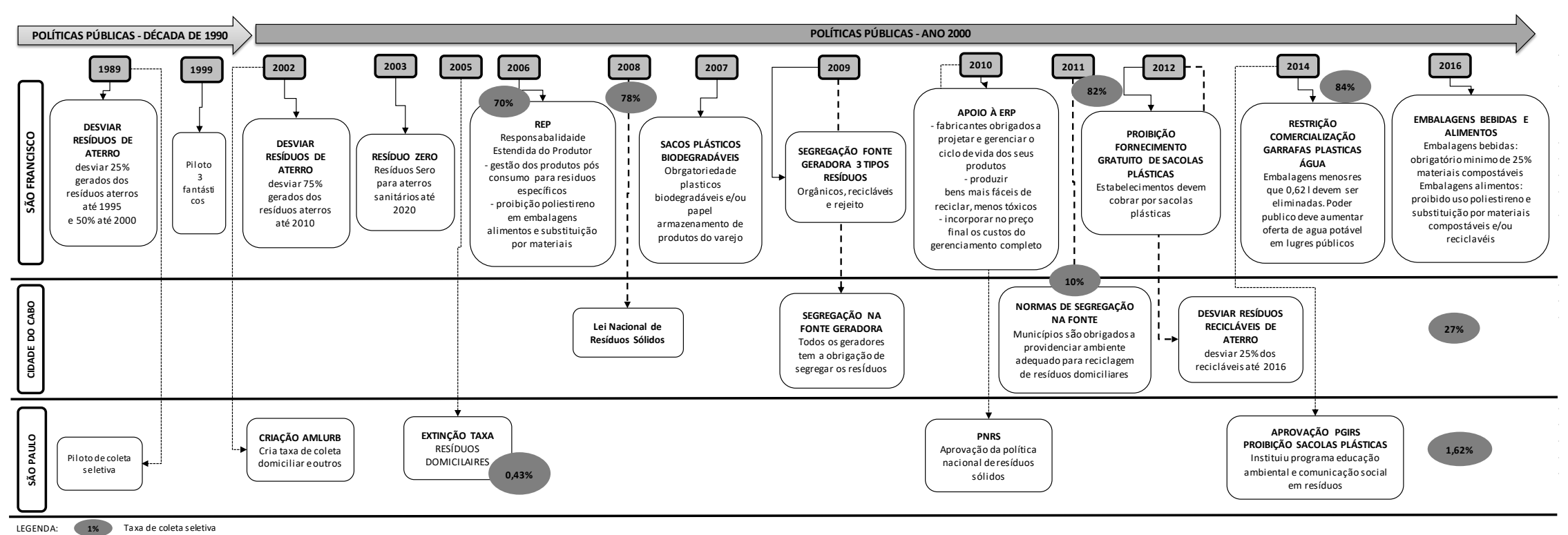

Elaboração: a autora 


\subsection{Resultados da Avaliação}

\section{Caracterização das Coletas nos Municípios Estudados}

Avaliar variáveis da coleta de resíduos sólidos com segregação da fonte geradora é um elemento importante para se buscar melhorias nos sistemas de gestão e gerenciamento dos resíduos sólidos urbanos. A Tabela 24 apresenta a avaliação aplicada para os três municípios estudados.

Esta avaliação baseou-se no critério de notas adotado como método para identificar maior ou menor proximidade a bons sistemas de gerenciamento de resíduos sólidos, apoiado em 5 variáveis selecionadas: abrangência, frequência, eficiência, potencializadora e incorporadora.

Tabela 24 Avaliação da coleta de resíduos sólidos urbanos com segregação na fonte geradora para os municípios estudados

Coleta de Resíduos Sólidos Urbanos com Segregação na Fonte e Envio para Reutilização e Reciclagem

\begin{tabular}{clccc}
$\begin{array}{c}\text { N.o da } \\
\text { Variável }\end{array}$ & \multicolumn{1}{c}{ Variável } & $\begin{array}{c}\text { São } \\
\text { Francisco }\end{array}$ & $\begin{array}{c}\text { Cidade do } \\
\text { Cabo }\end{array}$ & $\begin{array}{c}\text { São } \\
\text { Paulo }\end{array}$ \\
\hline $\mathbf{1}$ & Abrangência & 3 & 2 & 1 \\
\hline $\mathbf{2}$ & Frequência & 3 & 2 & 1 \\
\hline $\mathbf{3}$ & Eficiência & 3 & 2 & 1 \\
\hline $\mathbf{4}$ & Potencializadora & 3 & 2 & 1 \\
\hline $\mathbf{5}$ & Incorporadora & 1 & 3 & 2 \\
\hline & Nota Total & $\mathbf{1 3}$ & $\mathbf{1 1}$ & $\mathbf{6}$ \\
\hline
\end{tabular}

Elaboração: a autora

As notas atribuídas à avaliação das variáveis indicam que:

- São Francisco tem a melhor avaliação pois a coleta com segregação é universalizada, ou seja, está disponível para todo o território para três tipos de resíduos (orgânicos, recicláveis/secos e rejeitos). A frequência dos serviços é rigorosamente mantida, desde a criação do programa "Os Três Fantásticos". Em termos de eficiência, desde 2010, os programas implantados conseguem reaproveitar e reciclar $84 \%$ do total dos resíduos 
coletados, e ainda, potencializam os efeitos ambientais positivos da reciclagem em escalas regionais e nacionais;

- A Cidade do Cabo tem nota média, se comparada a São Francisco e São Paulo. A abrangência da coleta com segregação está disponível para parte do território, abrangendo diversas regiões e contempla dois tipos de resíduos (orgânicos e recicláveis/secos). A frequência dos serviços foi mantida desde a criação dos programas "Twink a Twice" e Segregação de Poda para compostagem, fato que reflete na eficiência média, onde são reciclados e processados resíduos recicláveis/secos e orgânicos. Em termos de potencialização dos impactos positivos na minimização da extração de recursos naturais, recebeu nota média, pois desvia do aterramento, $27 \%$ do total dos resíduos coletados. Recebeu nota máxima na variável potencializadora pois a coleta de resíduos com separação na fonte geradora é realizada por diversos atores sociais do terceiro setor (associações, cooperativas, ONGs, catadores independentes), empresas privadas de porte diversificado (pequeno, médio e grande). Todos estes serviços são geridos pelo poder público local, gerando mais oportunidades econômicas na cadeia de reaproveitamento e reciclagem;

- São Paulo obteve a menor nota de avaliação, quando comparada aos dois outros municípios estudados. A abrangência da coleta com segregação está disponível para parte do território, concentrada em algumas regiões e engloba somente um tipo de resíduos, deixando de lado, os orgânicos, que representam mais de $50 \%$ dos RSU coletados. A frequência dos serviços ainda não é constante em todo território. $A$ eficiência da coleta com segregação na fonte é reduzida, pois ainda são coletados somente recicláveis/secos. Também não é muito potencializadora pois segundo as estimativas apenas cerca de 1,62\% dos RSU coletados são encaminhados para processos de reutilização e reciclagem, sendo reduzidos, os efeitos ambientais positivos da coleta. A 
coleta é mais incorporadora do que São Francisco e menor do que a Cidade do Cabo, pois também é realizada por cooperativas e associações, embora em número reduzido, quando comparada à coleta de recicláveis realizada pelas concessionárias e, assim como, não incorpora empresas de pequeno porte neste tipo de serviço.

\section{Políticas públicas e instrumentos legais e de planejamento}

As políticas públicas e seus instrumentos legais de gestão de resíduos sólidos urbanos devem materializar, em nível local, os objetivos regionais e nacionais de minimização dos impactos do aquecimento global. A Tabela 25 apresenta a avaliação aplicada para os três municípios estudados.

Esta avaliação baseou-se no critério de notas adotado como método para identificar políticas sustentáveis e instrumentos viáveis, apoiado em cinco variáveis selecionadas: recuperação de custos, obrigatoriedade de segregação na fonte geradora, planos e programas claros com metas, programas complementares de reutilização e reciclagem e divulgação.

Tabela 25 Avaliação das políticas públicas de resíduos sólidos urbanos para os três municípios estudados

\begin{tabular}{ccccc}
\hline $\begin{array}{l}\text { Identificação das políticas públicas } \\
\text { e respectivos instrumentos legais } \\
\text { e de planejamento em vigor nos } \\
\text { municípios }\end{array}$ & \multicolumn{3}{c}{ Nota por Município } \\
$\begin{array}{c}\text { N.o da } \\
\text { Variável }\end{array}$ & $\quad$ Variável & $\begin{array}{c}\text { São } \\
\text { Francisco }\end{array}$ & $\begin{array}{c}\text { Cidade do } \\
\text { Cabo }\end{array}$ & $\begin{array}{c}\text { São } \\
\text { Paulo }\end{array}$ \\
\hline 7 & $\begin{array}{l}\text { Recuperação de custos } \\
8\end{array}$ & 3 & 2 & 1 \\
\hline $8 \quad \begin{array}{l}\text { Políticas públicas com } \\
\text { obrigatoriedade de } \\
\text { segregação na fonte } \\
\text { geradora }\end{array}$ & 3 & 2 & 1 \\
\hline 9 & $\begin{array}{l}\text { Planos e programas } \\
\text { claros com metas }\end{array}$ & 3 & 3 & 1 \\
\hline 10 & $\begin{array}{l}\text { Programas } \\
\text { complementares de } \\
\text { reutilização e } \\
\text { reciclagem }\end{array}$ & 3 & 2 & 1 \\
\hline
\end{tabular}




\begin{abstract}
Identificação das políticas públicas
e respectivos instrumentos legais

e de planejamento em vigor nos municípios
\end{abstract}

\begin{tabular}{ccccc}
$\begin{array}{c}\text { N.o da } \\
\text { Variável }\end{array}$ & Variável & $\begin{array}{c}\text { São } \\
\text { Francisco }\end{array}$ & $\begin{array}{c}\text { Cidade do } \\
\text { Cabo }\end{array}$ & $\begin{array}{c}\text { São } \\
\text { Paulo }\end{array}$ \\
\hline 11 & Divulgação & 3 & 3 & 1 \\
\hline & Nota Total & 15 & 12 & 5 \\
\hline
\end{tabular}

Elaboração: a autora

\section{Nota por Município}

As notas da avaliação das variáveis referentes as políticas públicas para a gestão dos RSU indicam que:

- São Francisco é a cidade mais eficiente em termos de políticas públicas pois a recuperação de custos é eficiente, permitindo que o gerador utilize os serviços em função das quantidades geradas, diretamente junto à empresa privada concessionária dos serviços. A separação na fonte geradora é obrigatória para todos os geradores, com fiscalização eficiente e abrangente, precedida de ações de educação e esclarecimentos quanto à forma correta de separação e acondicionamento dos resíduos em contentores. As metas estabelecidas nos planos e programas de resíduos sólidos são normalmente alcançadas, revisadas e realistas, estando à disposição da sociedade, as comprovações de seus cumprimentos assumidos em políticas e/ou instrumentos legais. Os programas de minimização de RSU são bem abrangentes, isto é, englobam uma gama variada de tipos de resíduos e estão disponibilizados à toda população que participa em diversos idiomas. Para a divulgação são utilizadas as mídias sociais, inclusive com disponibilidade de materiais didáticos digitais para acesso, sendo responsabilidade conjunta do Departamento de Meio Ambiente e empresa concessionária;

- A Cidade do Cabo recebeu nota média no quesito políticas públicas, quando comparada com São Francisco, porém, com nota bem próxima à 
São Francisco. Contribuem para isto fatores como: recuperação de custos dos serviços com cobrança direta ao gerador e obrigatoriedade de segregação dos resíduos na fonte geradora. Entretanto, no quesito abrangência da oferta dos serviços e fiscalização, ainda fica com nota menor que São Francisco. As metas são claramente definidas, exequíveis, sendo revisadas anualmente e possuem orçamento predeterminado. A divulgação da necessidade de segregação dos resíduos na fonte é realizada em diversos idiomas também, sendo responsabilidade do Departamento de Resíduos Sólidos;

- Na avaliação das políticas públicas, São Paulo permanece com a nota mais baixa, bem distante das outras duas cidades. O município necessita de melhorias significativas em termos de gestão e gerenciamento de RSU com vistas a aumentar a participação da população na segregação na fonte e, consequentemente, as taxas de reciclagem dos RSU. Não há cobrança de taxa específica de resíduos como nas demais cidades; as metas do plano atual de resíduos sólidos (PGIRS) foram muito audaciosas, sem estabelecer um plano de negócios para sua execução ou um planejamento executivo; não há obrigatoriedade de segregação de resíduos na fonte geradora e não existe padronização (contentor) para o armazenamento de resíduos, fato que contribui para que os grandes geradores (mais que $200 \mathrm{l} / \mathrm{dia}$ ) utilizem os serviços que devem ocorrer somente para os pequenos geradores (até $200 \mathrm{l} / \mathrm{dia}$ ); os programas complementares de segregação de resíduos são bem reduzidos, quando se compara aos demais municípios que geram quantidades diárias muito menores; apesar de existir instrumento legal que determina a divulgação da segregação dos resíduos na fonte geradora e a necessidade de divulgar e mobilizar a população para participar da coleta seletiva, não existe divulgação adequada em termos 
de frequência, abrangência e método e, ainda, esta responsabilidade foi repassada aos concessionários de serviços de limpeza urbana.

A avaliação final dos municípios estudados, a partir do conjunto das variáveis da coleta seletivas e das políticas públicas, apontou que São Francisco é o município mais sustentável em termos de gestão holística dos resíduos, quando se compara a aderência às políticas públicas gerais para combater ao aquecimento global associada, aos benefícios de saúde pública gerados pelo gerenciamento integrado de resíduos sólidos (Quadro 29).

Quadro 29 Resultado final da avaliação da coleta seletiva e políticas públicas para os municípios estudados

\begin{tabular}{lccc}
\hline Conjunto de variáveis & São Francisco & $\begin{array}{c}\text { Cidade do } \\
\text { Cabo }\end{array}$ & São Paulo \\
\hline Coleta & 13 & 11 & 6 \\
\hline Políticas Públicas & 15 & 12 & 5 \\
\hline Nota Final & $\mathbf{2 8}$ & $\mathbf{2 3}$ & $\mathbf{1 1}$ \\
\hline
\end{tabular}

Elaboração: a autora

Verificou-se que, em São Francisco, a adoção de um conjunto de políticas públicas para alcançar o conceito de Resíduos Zero foi evoluindo ao longo do período estudado, chegando a ser implantadas mais recentemente, determinações com restrições aos processos produtivos (exigência de embalagens biodegradáveis, proibição do uso de materiais com reduzido mercado para reciclagem) e ao consumo (proibição da comercialização de água engarrafada), o que propicia alcançar taxa de $100 \%$ do desvio de resíduos do aterramento. Desviar $100 \%$ de resíduos do aterramento requer políticas públicas e ações que alteram os processos de extração, produção, comercialização e consumo de produtos (ZAMAN, 2014). Neste sentido, São Francisco tem sido um caso mundial de sucesso.

A Cidade do Cabo, com a segunda melhor avaliação (Quadro 29) caminha em direção à sustentabilidade pois suas ações propiciam a minimização dos riscos associados às doenças causadas pelo gerenciamento inadequado de 
resíduos sólidos, potencializam a redução dos gases de efeito estufa e contribuem com o aumento da vida útil dos aterros sanitários. Porém, ainda precisa estabelecer novas ações para a redução da exploração dos recursos naturais, do consumo energia elétrica e do uso de combustíveis fósseis, potencializando a economia circular.

São Paulo obteve a menor nota, sendo o menos sustentável, pelos seguintes fatores: reduzida capacidade de reutilizar e reciclar os resíduos sólidos urbanos (1,62\% em 2016) decorrente da não universalização da coleta seletiva; método de disposição final predominante é o aterramento, na direção oposta do conceito Resíduo Zero; as políticas públicas de resíduos não têm caráter obrigatório. Consequentemente, na escala territorial do município, a minimização dos riscos associados às doenças causadas pelo gerenciamento inadequado de resíduos sólidos, a redução da exploração dos recursos naturais, a potencialização à economia circular, são insuficientemente tratadas pelas políticas públicas de resíduos sólidos.

Com base nos resultados obtidos, algumas considerações podem ser feitas:

- A existência de políticas públicas bem definidas, planejadas em nível executivo, com recursos financeiros, humanos e logísticos mapeados e integradas aos outros temas da gestão do município são essenciais para o sucesso da gestão integrada de resíduos sólidos com altas taxas de coleta seletiva ou Resíduos Zero. Este vem sendo um dos diferenciais de sucesso para alcance de taxas de coleta seletiva de São Francisco (mais de $80 \%$ ). Políticas públicas devem ser detalhadas até o nível de ações operacionais, sendo ajustadas conforme a evolução do projeto ou tema para que foi pensada, "sendo flexível para repensar decisões, testar alternativas e reavaliar programas" e ainda, "a falta de atenção aos detalhes é uma característica intrínseca aos gestores públicos que 
ignoram dimensões importantes de implantação na definição das políticas públicas" (DUFLO, 2017);

- Na Cidade do Cabo, apesar de poucas políticas públicas em vigor, as metas vêm sendo cumpridas, especialmente no quesito de atender a política nacional de resíduos sul-africana em relação ao desvio de resíduos do aterramento. Além disto, a continuidade das ações dos planos integrados de resíduos, independente das lideranças partidárias e a recuperação dos custos têm colaborado, em poucos anos, com o aumento da taxa de coleta seletiva;

- Em São Paulo, além de poucas políticas públicas focadas no aumento da taxa de coleta seletiva, a segregação dos resíduos na fonte geradora não é uma obrigatoriedade legal municipal e os munícipes não conhecem o custo dos serviços de limpeza pública, diferentemente de São Francisco e da Cidade do Cabo, onde são cobradas taxas específicas, que dependem do volume de resíduos. O valor pago pelos munícipes embutidos no IPTU para a limpeza urbana poderia ser desagregado, de forma que o gerador pudesse identificar o valor dos serviços que usa, estimulando a minimização dos resíduos. Apesar de não terem sido encontrados, durante a pesquisa bibliográfica e levantamento de campo, relatórios e documentos públicos sobre as campanhas de sensibilização e mobilização social da AMLURB e seus prestadores de serviço, verificou-se que a população tem contribuído, ainda que de modo tímido, com a segregação dos resíduos e envio para a coleta seletiva diferenciada realizada pelas concessionárias. Assim, se a divulgação prevista nas políticas públicas fosse mais agressiva em termos de divulgação na mídia, os números poderiam aumentar rapidamente. Conforme foi apresentado, já existem regiões da cidade de São Paulo cujas quantidades de resíduos coletados seletivamente são maiores. Partindo desta premissa, seria pertinente que a administração municipal 
implantasse um projeto piloto de integração entre as iniciativas privadas de recepção de resíduos (supermercados, lojas, centros comerciais e outros), as cooperativas e associações de catadores, a coleta seletiva diferenciada (concessionárias) com divulgação da necessidade de segregação dos resíduos, usando redes existentes para tal mobilização para multiplicação da mensagem (unidades de ensino, administradoras de condomínios, entidades religiosas, ONGs, associações profissionais e esportivas, dentre outros), de forma a atingir um público diversificado, gerando um efeito bola de neve.

- Verificou-se também, uma tendência mundial, de redes de varejo de várias cidades, inclusive na Cidade do Cabo, possuírem programas que estimulam a recompra de embalagens ${ }^{14}$ específicas, visando a logística reversa. Este tipo de iniciativa seria fundamental para ser implantada, exatamente nas regiões de São Paulo, próximas aos recursos hídricos, considerando que a coleta seletiva nestas regiões tem menor abrangência e eficiência, acarretando o carreamento de embalagens para os sistemas de macro e micro drenagens. Apesar do importante trabalho realizado pelas cooperativas e associações de catadores com a execução da coleta seletiva solidária, estes serviços precisam estar mais inseridos na gestão dos resíduos sólidos urbanos pela AMLURB. Poderia ser adequado, repensar abrangência (setorização), o tipo parceira, equipamentos envolvidos e distribuição geográfica das cooperativas e associações de catadores haja vista que, conforme foi verificado nos dados quantitativos de resíduos secos coletados (coleta solidária), a participação no total de resíduos coletados seletivamente é ainda reduzida. Magni (2011) apontou em sua pesquisa que “(...) existem fragilidades das parceiras existentes entre cooperativas de catadores e

\footnotetext{
14 Algumas destas iniciativas estão sendo implantadas em São Paulo (Retorna Machine da empresa
} Triciclo) 
as prefeituras municipais" e que estas fragilidades estão associadas ao "aspecto de vantagens efetivas trazidas aos cooperados" (MAGNI, 2011: 106). 


\section{CONCLUSÕES E RECOMENDAÇÕES}

Os resultados das pesquisas realizadas em São Francisco, Cidade do Cabo e São Paulo apontam que o sucesso de políticas públicas municipais específicas para a segregação na fonte geradora e coleta seletiva de resíduos sólidos urbanos depende de diversos fatores políticos, culturais, econômicos e não apenas das técnicas empregadas. Resultados demonstraram, outrossim, que um estudo de múltiplos casos foi adequado para destacar diferenças que ocorrem ao redor do mundo e que o sucesso de uma política pública não necessariamente está relacionado ao aporte de recursos financeiros. Há muito que uma cidade pode aprender com a experiência de outra, mesmo entre países de renda média, como foi o caso das duas cidades do BRICS. A Cidade do Cabo conseguiu eficiência maior que São Paulo, em menor período de tempo. Entretanto, São Paulo tem um potencial de indústria de reciclagem maior que Cidade do Cabo, bem menos industrializada que São Paulo e com problemas sociais semelhantes. Conclui-se, assim, que a escolha das cidades e do método foi apropriada para o objetivo proposto nesta tese e serviu para alcançar seus objetivos.

Concluiu-se, também, que cidades em países de renda média continuam a desperdiçar volumes de recursos naturais e econômicos, que são literalmente enterrados a custos elevadíssimos, sem que a população, em sua maioria, tenha consciência deste problema e possa se engajar de forma responsável para minimizá-lo.

A inserção socioprodutiva de catadores, importante para geração de emprego e renda para uma parcela desfavorecida da população no Brasil e na África, igualmente precisa evoluir para um possível modelo de pequenos negócios, como vem tentando a Cidade do Cabo. 
Urge, assim, uma vontade política maior para o estabelecimento de programas de Lixo Zero nas cidades do mundo, um dos compromissos assumidos com os Objetivos do Desenvolvimento Sustentável.

Assim, a partir da realidade encontrada nos três municípios, pode-se listar alguns dos fatores de sucesso para desviar os resíduos sólidos urbanos do aterramento e contribuir com a melhoria dos sistemas de coleta seletiva e reciclagem e, consequentemente, cooperar com a melhoria da saúde e com a minimização de impactos ambientais:

- Implantação de políticas públicas de gerenciamento de resíduos sólidos factíveis e em consonância com outros temas de gestão das administrações municipais;

- Criação e implementação de instrumentos legais que garantam a continuidade de programas de segregação de resíduos ao longo das diferentes vertentes políticas-administrativas dos municípios;

- Instituição da obrigatoriedade da segregação dos resíduos na fonte geradora;

- Regionalização das ações de segregação dos RSU em função das particularidades de regiões administrativas;

- Implantação da cobrança de taxa de coleta para garantir a manutenção e/ou a evolução da coleta seletiva/reciclagem;

- Execução de campanhas publicitárias em massa para divulgação da correta segregação dos resíduos, assim como, horários, locais de entrega de resíduos, existência de programas complementares - enfim, todos os esclarecimentos que devem ser dados à sociedade para garantir a participação e motivação ao longo do tempo;

No caso de São Paulo que foi o município com a menor nota na avaliação das variáveis analisadas, pode-se recomendar as seguintes ações, especificamente: 


\section{AMLURB:}

- Rever o PGIRS, sob a ótica de plano executivo, contendo, minimamente: revisão das metas de coleta seletiva; criação de indicadores factíveis de serem monitorados (compatibilidade dos limites dos circuitos de coleta versus limites das Prefeituras Regionais); fazer estudo de viabilidade econômica das ações definidas no Plano; elaborar cronograma executivo das ações e definir responsáveis pela execução; avaliar se existe a possibilidade da coleta seletiva solidaria ser ampliada ou se existem outras alternativas, dentre outros;

- Fortalecer a coleta seletiva nas Prefeituras Regionais que são as 10 maiores geradoras de resíduos domiciliárias, de forma a potencializar rapidamente o aumento da taxa de coleta seletiva e também, nas Prefeituras Regionais que estão inseridas nas áreas de proteção de mananciais (várzea do rio Tietê e represas Billings e Guarapiranga).

\section{ADMINISTRAÇÃO MUNICIPAL DE SÃO PAULO:}

- Criar instrumento legal municipal para a obrigatoriedade da segregação de resíduos na fonte geradora;

- Rever a forma de cobrança dos serviços de limpeza urbana que são contemplados no IPTU e avaliar a viabilidade da criação de taxa específica de coleta de resíduos;

- Regionalizar o território, com políticas públicas diferenciadas, associadas às especificidades de renda, população, quantidade de resíduos coletados, taxas de coleta seletiva, tipo de coleta seletiva (diferenciada ou solidária) e atributos socioambientais;

- Executar campanhas publicitárias para a divulgação dos horários e locais da coleta seletiva e forma correta de segregação dos resíduos sólidos urbanos. 


\section{REFERÊNCIAS}

ASSOCIAÇÃO BRASILEIRA DE NORMAS TÉCNICAS. NBR 10.004: Resíduos sólidos - Classificação. Segunda edição, 31.05.2004. Rio de Janeiro, p. 71.

BENSON, K; VANQA-MGIJIMA, N. Organizing on the Streets: A Study of Reclaimers in the Streets of Cape Town. International Labour Research \& Information Group (ILRIG), 2010. WIEGO Organizing Brief No. 4. Published by Women in Informal Employment: Globalizing and Organizing (WIEGO). Cambridge, MA, USA. Disponível em: http://www.wiego.org/sites/default/files/publications/files/Benson-VangaMgijima_WIEGO_OB4.pdf. Acessado em: 03/03/2017.

BESEN, G.R.; RIBEIRO, H.; GÜNTHER, W.M.R; JACOBI, P.R.. Coleta seletiva na Região Metropolitana de São Paulo: impactos da Política Nacional de Resíduos Sólidos. Ambiente e Sociedade. São Paulo, v. XVII, № 3, p 259-278, jul - set 2014.

BOCHNER, R. Acidentes Por Animais Peçonhentos: Aspectos Históricos, Epidemiológicos, Ambientais e Socioeconômicos. Tese apresentada a Escola Nacional de Saúde Pública Sérgio Arouca como requisito à obtenção do Título de Doutor em Saúde Pública. Rio de Janeiro, outubro de 2003. Disponível em: http://www.arca.fiocruz.br/bitstream/icict/4412/2/174.pdf. Acessado em: 15/08/2017.

BRAGA, A.F., RIBEIRO, H., GÜNTHER, W.M.R. Preliminary evaluation of the program goals for recycling solid waste in the São Paulo municipality, Brazil. Proceedings Sardinia 2017. Sixteenth International Waste Management and Landfill Symposium 2 - 6 October 2017. S. Margherita di Pula, Cagliari, Italy. CIBA Publisher, Italy

BRASIL. Constituição (1988). Constituição da República Federativa do Brasil. Brasília, DF: Senado Federal: Centro Gráfico, 1988. 292 p. Disponível em: http://www.planalto.gov.br/ccivil_03/constituicao/constituicaocompilado.htm. Acessado em 20/08/2017.

BRASIL. ITAMARATY, 2017. Informações sobre o BRICS. Disponível em: http://brics.itamaraty.gov.br/pt-br/sobre-o-brics/informacao-sobre-o-brics. Acessado em: 09/12/2016.

BRASIL. Lei 12.305, de 02 de agosto de 2010. Institui a Política Nacional de Resíduos Sólidos; altera a Lei no 9.605, de 12 de fevereiro de 1998; e dá outras providências. Diário Oficial da União, Brasília, DF, 03 ago.2010. 
BRASIL. MINISTÉRIO DAS CIDADES. Secretaria Nacional de Saneamento Ambiental. Sistema Nacional de Informações sobre Saneamento: diagnóstico do manejo de resíduos sólidos urbanos - 2014. - Brasília: MCIDADES.SNSA, 2016.

BRASIL. MINISTÉRIO DO MEIO AMBIENTE. CONSELHO NACIONAL DO MEIO AMBIENTE- Resolução CONAMA no 316, de 29 de outubro de 2002; dispõe sobre procedimentos e critérios para o funcionamento de sistemas de tratamento térmico de resíduos. Brasil, 2002.

BRASIL. MINISTÉRIO DO MEIO AMBIENTE. Logística Reversa. Disponível em: <http://www.mma.gov.br/cidades-sustentaveis/residuos-perigosos/logisticareversa>, 2014. Acessado em: 12/04/2017.

BRASIL. SINIR. Sistema Nacional de Informações sobre a Gestão de Resíduos Sólidos. Manual de diretrizes operacionais para implantação e operação do sistema de logística reversa. Brasília, DF: Ministério do Meio Ambiente, 2015.

BRINGHENTI, J.R.; GÜNTHER, W.M.R.. Participação social em programas de coleta seletiva de resíduos sólidos urbanos. Artigo Técnico. Revista de Engenharia Sanitária e Ambiental, v16 no4, out/dez 2011, p: 421-430

CALIFORNIA DEPARTMENT OF RESOURCES RECYCLING AND RECOVERY (CALRECYCLE). AB 341 Report to the Legislature. August, 2015a. Disponível em: < http://www.calrecycle.ca.gov/LGCentral/Reports/DRS/Destination/JurDspFa.asp x. Acessado em: 10/04/2015

CALIFORNIA DEPARTMENT OF RESOURCES RECYCLING AND RECOVERY (CALRECYCLE). State of Disposal in California. March 2015b. Disponível em: <http: http://www.calrecycle.ca.gov/LGCentral/Reports/DRS/Origin/WFOrginAnnual.as px _>. Acessado em: 10/04/2015

CALIFORNIA DEPARTMENT OF RESOURCES RECYCLING AND RECOVERY (CALRECYCLE). State of Disposal in California Updated 2016. February 2016. Disponível em: http://www.calrecycle.ca.gov/LGCentral/Reports/DRS/default.aspx. Acessado em: 10/04/2015.

CITY OF CAPE TOWN Integrated Waste Management By-law, 2009. Published in Province of Western Cape: Provincial Gazette no. 6651 on 21 August 2009. Disponível em: https://openbylaws.org.za/za-cpt/act/bylaw/2009/integrated-waste-management/. Acessado em: 19/03/2017

COMPOSTA SÃO PAULO. Disponível em: https://www.compostasaopaulo.eco.br/. Acessado em: 23/04/2017 
COUNTY AND CITY OF SAN FRANCISCO. Annual Report of The Department of The Environment, 2012a. San Francisco, USA. Disponível em: http://sfenvironment.org/sites/default/files/fliers/files/sfe_ou_annualreport_2012s m.pdf. Acessado em: 02/11/2016.

COUNTY AND CITY OF SAN FRANCISCO. Boarding of Supervisors. Ordinance 81-07, March 22, 2007. Amendment of the Whole. File n.․ 070085. Plastic Bag Reduction. Disponível em: https://sfbos.org/ordinances. Acessado em: 02/10/2016.

COUNTY AND CITY OF SAN FRANCISCO. Boarding of Supervisors. Reduction Ordinance 29506, November 14 2006a. Amendment of the Whole. File $n . .060944$. Ordinance for food service waste reduction. Disponível em: https://sfbos.org/ordinances. Acessado em: 02/10/2016.

COUNTY AND CITY OF SAN FRANCISCO. Boarding of Supervisors. Resolution 679-02, September 30, 2002. Amendment of the Whole. File $\mathrm{n}$. 021460. Resolution adopting a goal of $75 \%$ landfill diversion by the San Francisco Commission on the Environmental. Disponível em: https://sfbos.org/ordinances. Acessado em: 01/10/2016.

COUNTY AND CITY OF SAN FRANCISCO. Boarding of Supervisors. Resolution n. 0 002-03-COE, March 6, 2003. Resolution adopting a date of 2020 for San Francisco to achieve the goal of zero waste to landfill. Disponível em: https://sfbos.org/ordinances. Acessado em: 04/10/2016.

COUNTY AND CITY OF SAN FRANCISCO. Boarding of Supervisors. Resolution 100475. April 20 2010a. Amendment of the Whole. File n. 100475. Supporting Establishment of Stawide Extended Producer Responsibility System and Framework. Disponível em: https://sfbos.org/resolutions-2010. Acessado em: 04/10/2016.

COUNTY AND CITY OF SAN FRANCISCO. Bureau of Land Management, Esri, HERE, DeLorme, Intermap, USGS, NGA, EPA, USDA, NPS. 2012b. Disponível em: <https://sfgov.maps.arcgis.com/home/index.html>. Acessado em: 02/11/2016

COUNTY AND CITY OF SAN FRANCISCO. Department of Building Inspection. Administrative Bulletin 088-10. San Francisco Building Code. Collection and Storage of Trash, Recycling and Compostable Material. 2010a. Disponível em: https://sfenvironment.org/sites/default/files/fliers/files/sfe_zw_ab088_010114.pdf . Acessado em: 09/10/2016. 
COUNTY AND CITY OF SAN FRANCISCO. ORDINANCE n.ำ 140/16. FILE N. 웅 160383. AMENDED IN BOARD 7/12/2016. Environment Code - Food Service and Packaging Waste Reduction. Disponível em: https://sfenvironment.org/sites/default/files/fliers/files/sfe_zw_fsw_packing_wast ereduction_ordinance.pdf. Acessado em 07/05/2017

COUNTY AND CITY OF SAN FRANCISCO. ORDINANCE n. 33/12. FILE NO. 101055. 2012c. Environment Code - Checkout Bags; Checkout Bag Charge. Disponível em: https://sfenvironment.org/checkout-bag-ordinance. Acessado em 09/10/2016

COUNTY AND CITY OF SAN FRANCISCO. RESOLUTION NO. 217-16. FILE NO. 160564. Urging the State of California to Require a Minimum of $25 \%$ Post-Consumer Recycled Content in Plastic Beverage Containers. Disponível em: https://sfenvironment.org/sites/default/files/fliers/files/sfe_zw_bevcontainer_recy cledcontent_resolution.pdf. Acessado em 09/12/2016.

COUNTY AND CITY OF SAN FRANCISCO. Resolution. n. 28/14. Board of Supervisors and the Mayor. To restrict the sale or distribution on City property of drinking water. Disponível em: https://sfenvironment.org/policy/resolution-in-support-of-bottled-water-legislation. Acessado em 09/10/2016.

COUNTY AND CITY OF SAN FRANCISCO. SAN FRANCISCO ENVIRONMENTAL DEPARTMENT. The End of Trash. San Francisco Magazine. Disponível em: http://www.sfenvironment.org/news/the-end-of-trash. Acessado em 20/07/2015

COUNTY AND CITY OF SAN FRANCISCO. The Department of The Environment. San Francisco, USA: Waste Characterization Study. Final Report. March, 2006b. Disponível em: $<$ http://sfenvironment.org/sites/default/files/fliers/files/sfe_zw_waste_characteriz ation_study_2006.pdf>. Acessado em: 10/04/2015

DI PIETRO, M.S.Z. Direito Administrativo. 13ํㅡㄹição. São Paulo, Atlas, 2001.

DICIONÁRIO AURÉLIO. Versão on line. Disponível em: https://dicionariodoaurelio.com/reutilizar. Acessado: 07/08/2017. 
DRUMM, F.C., GERHARDT, A.E., FERNANDES, G. A., CHAGAS, P., SUCOLOTTI, M.S., KEMERICH, P.D.C.. Poluição atmosférica proveniente da queima de combustíveis derivados do petróleo em veículos automotores. Revista do Centro do Ciências Naturais e Exatas - UFSM, Santa Maria. Revista Eletrônica em Gestão, Educação e Tecnologia Ambiental REGET. V. 18 n. 1 Abr 2014, p. 66-78. Disponível em: < https://periodicos.ufsm.br/reget/article/download/10537/pdf>. Acessado em: 04/06/2017.

DUFLO, E.. The Economist as Plumber. MIT. Department of Economics Working Paper No. 17-03. 6 March 2017 Disponível em: https://papers.ssrn.com/sol3/papers.cfm?abstract_id=2927153. Acessado: 01/06/2018.

EUROPEAN COMMISSION. ENVIRONMENTAL. Waste. The EU's approach to waste management. Disponível em <http://ec.europa.eu/environment/waste/>. Acessado em: 15/01/2014.

EUROPEAN ENVIRONMENT AGENCY. Managing municipal solid waste a review of achievements in 32 European countries. EEA Report No 2/2013. Publications Office of the European Union. Copenhagen, 2013. Disponível em: file://D:/G_Recicling_2014/Managing\%20municipal\%20solid\%20waste.pdf. Acessado em: 14/10/2017.

EUROPEAN ENVIRONMENT AGENCY. Waste prevention in Europe: the status in 2013. No 9/2014. Publications Office of the European Union. Copenhagen, $2014 . \quad$ Disponível em: https://www.eea.europa.eu/themes/waste/municipal-waste. Acessado em: 23/07/2017.

EUROPEAN ENVIRONMENTAL AGENCY. Municipal waste management across European countries. Briefing Published 14 Nov 2016. Last modified 23 May 2017. Disponível em: https://www.eea.europa.eu/themes/waste/municipalwaste. Acessado em: 22/07/2017.

EUROPEAN ENVIRONMENTAL AGENCY. Well-being and the environment. Building a resource-efficient and circular economy in Europe. 1831-2772. Publications Office of the European Union. Copenhagen, 2014.

FERNANDES, I.F.A.L.; CARDOSO, L.F.P.B.. Revista Leviathan. Cadernos de Pesquisa Política N. 11 , pp. 121 - 144 , 2015121 A Política Externa Brasileira e 0 Grupo dos Brics. Disponível em: https://www.revistas.usp.br/leviathan/article/view/135212/131020. Acessado em: 09/12/2016. 
FORLIN, F.J.; FARIA, J.A.F. Considerações Sobre a Reciclagem de Embalagens Plásticas. Departamento de Tecnologia de Alimentos, FEA, UNICAMP. Polímeros: Ciência e Tecnologia, vol. 12, no 1, p. 1-10, 2002.

FORTES, P.A.C.; RIBEIRO, H.. Saúde Global em tempos de globalização. Revista Saúde e Sociedade. São Paulo, v.23, n.2, p.366-375, 2014. Disponível em: http://www.scielo.br/pdf/sausoc/v23n2/0104-1290-sausoc-23-2-0366.pdf. Acessado: 10/06/2018

FUNASA. Manual de Saneamento. 4ํe edição. Brasília, 2015. Disponível em: http://www.funasa.gov.br/biblioteca-eletronica/publicacoes/engenharia-desaude-publica/-/asset_publisher/ZM23z1KP6s6q/content/manual-desaneamento?inheritRedirect=false. Acessado em: 21/010/2016 GOUVEIA, N; PRADO, R.R. Riscos à saúde em áreas próximas a aterros de resíduos sólidos urbanos. Revista Saúde Pública, São Paulo, 44 (5): 859-66, 2010.

GÜNTHER, W.M.R. Resíduos sólidos no contexto da saúde ambiental. Texto de sistematização crítica de parte da obra da candidata apresentado ao Departamento de Saúde Ambiental da Faculdade de Saúde Pública da Universidade de São Paulo para obtenção do título de Professor Livre Docente. São Paulo, 2008.

HUTCHINSON, A. Is Recycling Worth It? PM Investigates its Economic and Environmental Impact. Nov. 2008. Disponível em: http://www.popularmechanics.com/science/environment/a3752/4291566/Nov 12, $2008 @$ 7:00 PM. Acessado em: 07/06/2015

ICF CONSULTING. Determination of the impact of waste management activities on greenhouse gas emissions: 2005 Update. Final Report. Contract No. K2216-04-0006. Submitted to: Environment Canada and Natural Resources Canada. Submitted by: ICF Consulting. October 31, 2005. Disponível em: http://www.rcbc.ca/files/u3/ICF-final-report.pdf. Acessado em: 22/07/2017.

INSTITUTO BUTANTÃ. Acidentes com animais peçonhentos. Ficha técnica. N.- 09 . Disponível em: http://www.saude.sp.gov.br/resources/ses/perfil/cidadao/temas-desaude/animais_peconhentos.pdf. Acessado em: 03/03/2016.

ISWA International Solid Waste Association. Solid Waste: Guidelines for successful planning. $2011 \quad$ (?). Disponível em: http://www.iswa.org/media/publications/knowledge-base/. Acessado em: 10/08/2016. 
JACOBI, P.R.; BESEN, G.R.. Política e accountability da gestão de resíduos sólidos no município de São Paulo. In: Diana María Cuadros De Vílchez. Mecanismos de accountability en la gestión de residuos sólidos en Colombia y Brasil. Bogotá, D.C. Los Libertadores. Fundacion Universitaria, 2017. p. 106 127.

KATZ, C. Putting San Francisco On the Road to Zero Waste by. Yale Environment 360. MAY 2014: Disponível em:http://e360.yale.edu/feature/interview_jack_macy_putting_san_francisco_on _the_road_to_zero_waste/2767/. Acessado em: 3/9/2016

LAKAN, C. Optimizing emissions targets for residential recycling programmes: Why 'more' is not necessarily better with respect to diversion. Waste Management \& Research 2016. Vol 34 [11] 1148-1156.

LIEBENBERG, C. J. Waste Recycling In Developing Countries In Africa: Barriers To Improving Reclamation Rates. Divisional Director, Environmental and Waste Management, Kwezi V3 Engineers, PO Box 36155, Menlo Park, 0102, South Africa. Proceedings Sardinia 2007, Eleventh International Waste Management and Landfill Symposium S. Margherita di Pula, Cagliari, Italy; 1 - 5 October 2007.

MABEE, W.. Circular Economies and Canada's Forest Sector. Presented at the Work in a Warming World (W3) Researchers' Workshop: "Greening Work in a Chilly Climate", Toronto, Canada, November, 2011. Disponível em: http://warming.apps01.yorku.ca/wp-content/uploads/WP_2011-

08_Mabee_Circular-Economies.pdf. Acessado em: 22/07/2017

MAGNI, A.A.C.. Cooperativas de catadores de resíduos sólidos urbanos: perspectivas de sustentabilidade. 2011. 116p. Dissertação (Mestrado em Saúde Pública) - Faculdade de Saúde Pública, Universidade de São Paulo, São Paulo.

MORAES, L.R.S.. Acondicionamento e coleta de resíduos sólidos domiciliares e impactos na saúde de crianças residentes em assentamentos periurbanos de Salvador. Caderno de Saúde Pública, Rio de Janeiro, 23 Sup. 4: S643-S649, 2007.

MORRIS, Jeffrey. Recycling versus incineration: an energy conservation analysis. Journal of Hazardous Material 47 (1996) 277 - 293. Disponível em: https://coordinamentorifiutienergia.noblogs.org/files/2013/02/IncenerimentoVSRi ciclaggio.pdf. Acessado em: 17/06/2017.

NAÇÕES UNIDAS. Objetivos de Desenvolvimento Sustentável. Transformando Nosso Mundo: A Agenda 2030 para o Desenvolvimento Sustentável. Setembro, $2015 . \quad$ Disponível em: https://nacoesunidas.org/pos2015/agenda2030/. Acessado em: 04/06/2017 
NATIONAL LEAGUE OF CITIES. Local US Governments. 2016. Disponível em: $\quad<\mathrm{ftp}: / /$ www.leginfo.ca.gov/pub/95-96/bill/asm/ab_27012750/ab_2706_cfa_960405_143918_asm_comm.html>. Acessado em: $02 / 11 / 2016$

O'NEILL, J.. Building better global economic BRICs. New York: Goldman Sachs. 2001.Disponível em: http://pro790512df.pic10.websiteonline.cn/upload/building-better-pdf_geEM.pdf. Acessado em: 09/12/2016.

ORDINANCE n. 33/12. FILE NO. 101055. Environment Code - Checkout Bags; Checkout Bag Charge.

POSSAMAI, F.P.; VIANA, E.; SCHULZ, H.E.; COSTA, M.M.; CASAGRANDE, E.. Lixões inativos na região carbonífera de Santa Catarina: analise dos riscos à saúde pública e ao meio ambiente. Revista Ciência e Saúde Coletiva, 12 (1): 171-179, Santa Catarina, 2007.

RECOLOGY ORGANICS WASTE ZERO. Facilities Jepson Prairie Organics. 2016d. Disponível em: <http://thecompoststore.com/index.php/compostfacilities-old/jepson-prairie-organics>. Acessado em: 02/11/2016.

RECOLOGY PENINSULA SERVICES. History Enterprise and Reinvention. A Proud Tradition of Service. 2016a. Disponível em: < http://recologypeninsulaservices.com/profile/history.htm>. Acessado em: 01/12/2016.

RECOLOGY SAN FRANCISCO. Our History and Team. Over 100 years of Service. 2016b. Disponível em: < https://recology.com/about-us/our-history/>. Acessado em: 01/12/2016.

RECOLOGY SAN FRANCISCO. Sunset Scavenger Golden Gate San Francisco. Programs and Services in San Francisco. 2016c. Disponível em: $<$ http://www.recologysf.com/index.php/recology-our-story/100-recologycommunity/569-services-to-san-francisco>. Acessado em: 02/11/2016.

REPUBLIC OF SOUTH AFRICA. Department of Environmental Affairs. National Domestic Waste Collection Standards, October 2010. Published in Government Gazette, 21 January 2011. Disponível em: https://www.environment.gov.za/sites/default/files/gazetted_notices/nemwa59of 2008_national_waste_domesticcollection_g33935_gn21.pdf. Acessado em: 20/10/2017.

REPUBLIC OF SOUTH AFRICA. DEPARTMENT OF ENVIRONMENTAL AFFAIRS. National Waste Information Baseline Report. Department of Environmental Affairs, Pretoria, South Africa, 2012. 
REPUBLIC OF SOUTH AFRICA. DEPARTMENT OF ENVIRONMENTAL AFFAIRS. South Africa Environment Outlook. Chapter 9: Waste Management Draft 2 version 3 April 2012. Disponível em: http://soer.deat.gov.za/dm_documents/Chapter_9_Waste_Management_wHOt 0.pdf. Acessado em: 10/10/2016.

REPUBLIC OF SOUTH AFRICA. National Environmental Management: Waste Act, 2008. $\quad N^{\circ}$. 59 of 2008. Disponível em: https://www.environment.gov.za/sites/default/files/legislations/nema_amendmen t_act59.pdf. Acessado em: 10/10/2017.

RIBEIRO, H. Relatório de Visita a Cape Town (n.p. circulação restrita). 2013.

RIBEIRO, H.; BESEN, G.R. Panorama da Coleta Seletiva no Brasil desafios e perspectivas a partir de três estudos de caso. In: Revista de Gestão Integrada em Saúde dos Trabalho e Meio Ambiente São Paulo, 2007. v. 2, no․ 4, artigo 1.. Agosto 2007.

SAMPAIO, M. A.. Justiça ambiental e saúde global: o caso do direito de acesso à coleta seletiva no Município de São Paulo. 2018. (n.p. circulação restrita). Tese de Doutorado. Faculdade de Saúde Pública, Universidade de São Paulo, São Paulo.

SÃO PAULO (Município). Decreto $\mathrm{n}^{\circ}$ 55.747, de 3/12/2014. Aprova o Programa de Educação Ambiental e Comunicação Social em Resíduos Sólidos do Município de São Paulo 2014/2033, bem como cria o Comitê Inter secretarial de Implementação do referido Programa. Disponível em: https://www.legisweb.com.br/legislacao/?id=278117. Acessado em: 19/03/2016

SÃO PAULO (Município). Decreto no 55.827, de 6/01/2015. Regulamenta a Lei no 15.374, de 18 de maio de 2011, que dispõe sobre a proibição da distribuição gratuita ou venda de sacolas plásticas a consumidores em todos os estabelecimentos comerciais do Município de São Paulo. Diário Oficial da Cidade de São Paulo, Ano 60, São Paulo, 07/01/2015, n.ํ03. Disponível em: http://www3.prefeitura.sp.gov.br/cadlem/secretarias/negocios_juridicos/cadlem/i ntegra.asp?alt=07012015D\%20558270000. Acessado em: 17/03/2016.

SÃO PAULO (Município). Empresa de Tecnologia da Informação e Comunicação do Município de São Paulo. PRODAM. Disponível em: http://www.prefeitura.sp.gov.br/cidade/secretarias/inovacao/prodam/noticias/?p= 201516. Acesso em: 10/04/2017.

SÃO PAULO (município). Lei Municipal 11.220, de 20/05/1992. Institui a divisão geográfica da área do município em distritos, revoga a lei no 10.932, de 15 de janeiro de 1991, e dá outras providências 
SÃO PAULO (município). Lei Municipal 13.478, de 30/12/2002.Dispõe sobre a organização do Sistema de Limpeza Urbana do Município de São Paulo; cria e estrutura seu órgão regulador; autoriza o Poder Público a delegar a execução dos serviços públicos mediante concessão ou permissão; institui a Taxa de Resíduos Sólidos Domiciliares - TRSD, a Taxa de Resíduos Sólidos de Serviços de Saúde - TRSS e a Taxa de Fiscalização dos Serviços de Limpeza Urbana - FISLURB; cria o Fundo Municipal de Limpeza Urbana - FMLU, e dá outras providências..

SÃO PAULO (Município). Plano de Gestão Integrada de Resíduos Sólidos PGIRS. São Paulo, $2014 . \quad$ Disponível em: http://www.prefeitura.sp.gov.br/cidade/secretarias/upload/servicos/arquivos/PGI RS-2014.pdf. Acessado em: 28/07/2015.

SÃO PAULO (Município). Resolução $n^{\circ}$ 109/AMLURB/2017. Reestrutura o Programa Socioambiental de Coleta Seletiva de Resíduos Recicláveis, e aprimora a Doação Social com Encargos para o Processamento de Resíduos Sólidos Domiciliares Secos provenientes do serviço público de coleta seletiva do Município de São Paulo. Disponível em: http://www.docidadesp.imprensaoficial.com.br/RenderizadorPDF.aspx?ClipID=8 80D5NC7CQ4NVe7J2K3L9OSKT30. Acessado em: 30/11/2017.

SÃO PAULO (Município). Secretaria de Serviços e Obras. Diretrizes para a destinação final dos resíduos sólidos no município de São Paulo. São Paulo, 1992.

SILVA, Angie \& Rosano, MICHELE \& STOCKER, LAURA \& GORISSEN, Leen. (2016). From waste to sustainable materials management: Three case studies of the transition journey. Waste Management. 61. 10.1016/j.wasman.2016.11.038. Acessado em: 10/02/2017.

SKINNER, John $\mathrm{H}$. The Road to Sustainable Solid Waste Management in North America. The Solid Waste Association of North America (SWANA).

STATE OF CALIFORNIA. DEPARTMENT OF RESOURCES RECYCLING AND RECOVERY. The Integrated Waste Management Act. AB 939, 1989. Disponível

em:

http://www.calrecycle.ca.gov/laws/legislation/calhist/1985to1989.htm. Acessado em: 18/10/2016.

TEIXEIRA, E. C; FELTES, S; SANTANA, E. R. R. Estudo das Emissões de Fontes Móveis na Região Metropolitana de Porto Alegre, Rio Grande do Sul. Química Nova, Vol. 31, pag. 244, 2008. Disponível em: http://www.scielo.br/scielo.php?script=sci_arttext\&pid=S010040422008000200010 . Acessado em: 04/06/2017. 
THE AFRICAN DEVELOPMENT BANK. Study on Solid Waste Management Options for Africa. July 2002.

THE SAN FRANCISCO PRESERVATION SOCIETY. A Brief History of San Francisco. 2016. Disponível em: <http://sfpsociety.org/sfhistory.html>. Acessado em: 03/12/2016

TISCHLER, J.. Alliances and Partnerships in Recycling in Cape Town, South Africa. The recycling system in Cape Town, working towards sustainability? Global Studies Working Papers. Institute of Geography. 09/2013. Eberhard Karls. Universitat Tubingen. Disponível em: https://publikationen.unituebingen.de/xmlui/bitstream/handle/10900/49883/pdf/GSWP_DA_Jeannine_Tis chler.pdf?sequence=1. Acessado em: 17/03/2018.

UNITED NATIONS HABITAT. Solid Waste Management in the World's Cities: Water and Sanitation in the World's Cities 2010. Disponível em: https://unhabitat.org/books/solid-waste-management-in-the-worlds-cities-waterand-sanitation-in-the-worlds-cities-2010-2/ Acessado em:03/07/2017.

UNITED NATIONS STATISTICS DIVISION. ENVIRONMENTAL INDICATORS (UNSTATS). Waste. Definitions \& Technical notes. 2011Disponível em: https://unstats.un.org/unsd/environment/wastetreatment.htm. Acessado: 07/07/2015

UNITED NATIONS. Industry. Municipal Solid Waste Action Statement and Plan. Provisional copy. Climate Summit 2014. UN Headquarters. New York, 23 September. Climate2014.

Disponível

em: http://www.un.org/climatechange/summit/wpcontent/uploads/sites/2/2014/07/INDUSTRY-Municipal-Solid-Waste-ActionStatement-and-Plan.pdf. Acessado em: 24/08/2017.

UNITED NATIONS. The World's Cities in 2016. Disponível em: http://www.un.org/en/development/desa/population/publications/pdf/urbanization /the_worlds_cities_in_2016_data_booklet.pdf. Acessado em: 02/04/2017

UNITED STATES CENSUS BUREAU. QuickFacts San Francisco County. California. $2016 . \quad$ Disponível em: http://www.census.gov/quickfacts/table/AGE115210/06075. Acessado em: 02/11/2016.

UNITED STATES ENVIRONMENTAL PROTECTION AGENCY (USEPA). Advancing Sustainable Materials Management: 2014 Fact Sheet Assessing Trends in Material Generation, Recycling, Composting, Combustion with Energy Recovery and Landfilling in the United States November. 2016. Disponível em: https://www.epa.gov/sites/production/files/201611/documents/2014_smmfactsheet_508.pdf. Acessado em: 10/01/2017. 
UNITED STATES ENVIRONMENTAL PROTECTION AGENCY (USEPA). Advancing Sustainable Materials Management: Facts and Figures 2013. Assessing Trends in Material Generation, Recycling and Disposal in the United States. June 2015. Disponível em: https://www.epa.gov/facts-and-figures-aboutmaterials-waste-and-recycling/advancing-sustainable-materials-management. Acessado em: 17/05/2017.

UNITED STATES ENVIRONMENTAL PROTECTION AGENCY (USEPA). Definition of Solid Waste and Hazardous Waste Recycling (40 CFR §§261.2 and 261.9). RCRA, Superfund \& EPCRA. October 2001. Disponível em: file:///D:/G_Recicling_2014/defsw_EPA.pdf. Acessado em: 14/10/2017.

UNITED STATES ENVIRONMENTAL PROTECTION AGENCY (USEPA). Managing and Transforming Waste Streams - A Tool for Communities. Zero Waste Case Study: San Francisco. 2018. Disponível em: https://www.epa.gov/transforming-waste-tool/zero-waste-case-study-sanfrancisco. Acessado em: 11/01/2018.

UNITED STATES ENVIRONMENTAL PROTECTION AGENCY (USEPA). The Resource Conservation and Recovery Act (RCRA), 1976. Disponível em: https://www.epa.gov/hw/criteria-definition-solid-waste-and-solid-and-hazardouswaste-exclusions\#solidwaste. Acessado em: 17/07/2017.
UNITED STATES. ENVIRONMENTAL PROTECTION AGENCY (USEPA).
Report on the Environment. 2017. file:///D:/G_Recicling_2014/MSW.pdf. Acessado em: 10/01/2017.

VAN KLUNDERT, A.; ANSCHÜTZ, J.. Integrated Sustainable Waste Management - the Concept is part of a set of five Tools for Decision-makers. The Netherlands, 2001. ISBN number of the series: 90-76639-02-7. Disponível em:

http://www.waste.nl/sites/waste.nl/files/product/files/tools_iswm_concept_eng1.p df. Acessado em: 15/06/2017.

WESTERN CAPE GOVERNMENTAL. Western Cape Integrated Waste Management Plan 2017 - 2022. March 2017. Disponível em: https://www.westerncape.gov.za/eadp/sites/eadp.westerncape.gov.za/files/yourresource-

library/Western\%20Cape\%20Integrated\%20Waste\%20Management\%20Plan\% 202017-2022.pdf. Acessado em: 01/03/2018.

WILSON, D.C; RODIC, L.; SCHEINERG, A.; VELIS, C.A.; ALABASTER, G. Comparative analysis of solid waste management in 20 cities. Waste Management \& Research, 2012 30: 237. DOI: 10.1177/0734242X12437569. Disponível em: http://wmr.sagepub.com/content/30/3/237. Acessado em: 19/07/2017. 
WORLD BANK. What a Waste. A Global Review of Solid Waste Management, 2012. Disponível em: http://www.ecobusiness.com/research/what-a-waste-a-global-review-of-solid-wastemanagement/. Acessado em: 21/011/2016.

YIN, R.K. Estudo de caso: planejamento e métodos. 3.ed. Porto Alegre: Bookman, 2005. 212p.

ZAMAN, A.U.. A comprehensive review of the development of zero waste management: lessons learned and guidelines. Journal of Cleaner Production, 2014. Disponível em: http://dx.doi.org/10.1016/j.jclepro.201412.013. Acessado em:11/04/2018 


\section{APÊNDICE}




\subsection{APÊNDICE 1: CONCEITOS DE RESÍDUOS SÓLIDOS}

\begin{tabular}{|c|c|c|}
\hline Localidade & Instrumento & Definição \\
\hline Brasil & $\begin{array}{l}\text { Resíduos Sólidos } \\
\text { Política Nacional de } \\
\text { Resíduos Sólidos do Brasil } \\
\text { (BRASIL, 2010) } \\
\text { Lei federal no 12.305/2010 }\end{array}$ & $\begin{array}{l}\text { Artigo } 3 \\
\text { XVI - resíduos sólidos: material, } \\
\text { substância, objeto ou bem } \\
\text { descartado resultante de } \\
\text { atividades humanas em } \\
\text { sociedade, a cuja destinação final } \\
\text { se procede, se propõe proceder } \\
\text { ou se está obrigado a proceder, } \\
\text { nos estados sólido ou semissólido, } \\
\text { bem como gases contidos em } \\
\text { recipientes e líquidos cujas } \\
\text { particularidades tornem inviável o } \\
\text { seu lançamento na rede pública } \\
\text { de esgotos ou em corpos d'água, } \\
\text { ou exijam para isso soluções } \\
\text { técnica ou economicamente } \\
\text { inviáveis em face da melhor } \\
\text { tecnologia disponível; }\end{array}$ \\
\hline Brasil & $\begin{array}{l}\text { Resíduos Sólidos } \\
\text { Associação Brasileira de } \\
\text { Normas Técnicas - ABNT } \\
\text { (NBR 10004, 2004) }\end{array}$ & $\begin{array}{l}3.1 \text { resíduos sólidos: Resíduos } \\
\text { nos estados sólido e semi-sólido, } \\
\text { que resultam de atividades de } \\
\text { origem industrial, doméstica, } \\
\text { hospitalar, comercial, agrícola, de } \\
\text { serviços e de varrição. Ficam } \\
\text { incluídos nesta definição os lodos } \\
\text { provenientes de sistemas de } \\
\text { tratamento de água, aqueles } \\
\text { gerados em equipamentos e } \\
\text { instalações de controle de } \\
\text { poluição, bem como determinados } \\
\text { líquidos cujas particularidades } \\
\text { tornem inviável o seu lançamento } \\
\text { na rede pública de esgotos ou } \\
\text { corpos de água, ou exijam para } \\
\text { isso soluções técnica e e } \\
\text { economicamente inviáveis em } \\
\text { face à melhor tecnologia } \\
\text { disponível. }\end{array}$ \\
\hline $\begin{array}{l}\text { África do } \\
\text { Sul }\end{array}$ & $\begin{array}{l}\text { Resíduos Sólidos } \\
\text { Waste Act, } 2008\end{array}$ & $\begin{array}{l}\text { Resíduos sólidos significam } \\
\text { qualquer substância, tenha ou não } \\
\text { essa substância, possibilidade de } \\
\text { ser reduzida, reutilizada, reciclada } \\
\text { ou recuperada. Ou seja, o } \\
\text { excedente, o não desejado, o } \\
\text { rejeitado, o descartado, o }\end{array}$ \\
\hline
\end{tabular}




\begin{tabular}{|c|c|c|}
\hline Localidade & Instrumento & Definição \\
\hline & & $\begin{array}{l}\text { abandonado ou descartado; que } \\
\text { não tem não tem mais uso para o } \\
\text { gerador ou para os propósitos de } \\
\text { produção; deve ser tratado ou } \\
\text { descartado; qualquer porção de } \\
\text { resíduo, uma vez reutilizado, } \\
\text { reciclado ou recuperado, deixa de } \\
\text { ser um resíduo }\end{array}$ \\
\hline $\begin{array}{l}\text { Estados } \\
\text { Unidos }\end{array}$ & $\begin{array}{l}\text { Resíduos Sólidos } \\
\text { USEPA, } 1976\end{array}$ & $\begin{array}{l}\text { Qualquer resíduo, refugo, lixo, } \\
\text { lodo de estação de tratamento de } \\
\text { águas residuais, água de planta } \\
\text { de tratamento de suprimento ou } \\
\text { instalação de controle de poluição } \\
\text { do ar e outros materiais } \\
\text { descartados, incluindo resíduos } \\
\text { sólido, líquido, semi sólido ou com } \\
\text { material gasoso, resultante de } \\
\text { atividades industrias, comerciais, } \\
\text { de mineração e de operações } \\
\text { agrícolas e de atividades } \\
\text { comunitárias. }\end{array}$ \\
\hline Brasil & $\begin{array}{l}\text { Resíduos Sólidos Urbanos } \\
\text { (RSU) } \\
\text { Política Nacional de } \\
\text { Resíduos Sólidos do Brasil } \\
\text { (BRASIL, 2010) } \\
\text { Lei federal no 12.305/2010 }\end{array}$ & $\begin{array}{l}\text { Artigo } 130 \\
\text { I- Quanto à origem: } \\
\text { a) resíduos domiciliares: os } \\
\text { originários de atividades } \\
\text { domésticas em residências } \\
\text { urbanas; } \\
\text { b) resíduos de limpeza urbana: os } \\
\text { originários da varrição, limpeza de } \\
\text { logradouros e vias públicas e } \\
\text { outros serviços de limpeza urbana; } \\
\text { c) resíduos sólidos urbanos: os } \\
\text { englobados nas alíneas "a" e "b" }\end{array}$ \\
\hline São Paulo & $\begin{array}{l}\text { Resíduos Sólidos Urbanos } \\
\text { (RSU) } \\
\text { Lei Municipal no } \\
\text { 13.478/2002 }\end{array}$ & $\begin{array}{l}\text { Artigo } 9 \\
\text { I - A coleta, transporte, tratamento } \\
\text { e destinação final de resíduos } \\
\text { sólidos de qualquer natureza; } \\
\text { II - A varrição e asseio de vias, } \\
\text { túneis, abrigos, monumentos, } \\
\text { sanitários, viadutos, elevados, } \\
\text { escadarias, passagens, vielas, } \\
\text { praças, mercados e demais } \\
\text { logradouros públicos; } \\
\text { III - A raspagem e remoção de }\end{array}$ \\
\hline
\end{tabular}




\begin{tabular}{|c|c|c|}
\hline Localidade & Instrumento & Definição \\
\hline & & $\begin{array}{l}\text { terra, areia e quaisquer materiais } \\
\text { carregados pelas águas pluviais } \\
\text { para as ruas e logradouros } \\
\text { públicos pavimentados; } \\
\text { IV - A desobstrução de bueiros, } \\
\text { bocas-de-lobo, poços de visita, } \\
\text { galerias pluviais e correlatos; } \\
\text { V - A implantação e operação de } \\
\text { transbordo e transferência, bem } \\
\text { como de unidades de } \\
\text { processamento, tratamento e } \\
\text { destinação final, necessárias à } \\
\text { execução dos serviços previstos } \\
\text { no inciso I; } \\
\text { VI - A limpeza de ruas e } \\
\text { logradouros públicos onde se } \\
\text { realizem feiras públicas e outros } \\
\text { eventos de acesso aberto ao } \\
\text { público; } \\
\text { VII - Os serviços de conservação } \\
\text { de áreas verdes de domínio } \\
\text { público; } \\
\text { VIII - A capinação, a raspagem, o } \\
\text { sacheamento e a roçada, bem } \\
\text { como o acondicionamento e coleta } \\
\text { dos resíduos provenientes dessas } \\
\text { atividades, visando à salubridade } \\
\text { ambiental e a promoção da } \\
\text { estética urbana do Município; } \\
\text { IX - A implantação e operação de } \\
\text { sistemas de triagem e separação } \\
\text { dos resíduos sólidos; } \\
\text { X - A limpeza de áreas e tanques } \\
\text { de contenção de enchentes. }\end{array}$ \\
\hline $\begin{array}{c}\text { África do } \\
\text { Sul }\end{array}$ & $\begin{array}{l}\text { Resíduos Sólidos urbanos } \\
\text { REPUBLIC OF SOUTH } \\
\text { AFRICA, } 2011\end{array}$ & $\begin{array}{l}\text { Os resíduos sólidos urbanos (ou } \\
\text { municipais) são aqueles que não } \\
\text { representam um risco imediato ou } \\
\text { ameaça para a saúde ou para o } \\
\text { meio ambiente e incluem resíduos } \\
\text { domésticos, resíduos de } \\
\text { construção e demolição, resíduos } \\
\text { comerciais e resíduos inertes. } \\
\text { (Waste Act, 2008). Os resíduos } \\
\text { domésticos são os "resíduos, } \\
\text { excluindo resíduos perigosos, que } \\
\text { emanam de instalações que são }\end{array}$ \\
\hline
\end{tabular}




\begin{tabular}{|c|c|c|}
\hline Localidade & Instrumento & Definição \\
\hline & & $\begin{array}{l}\text { usadas total ou principalmente } \\
\text { para fins residenciais, } \\
\text { educacionais, de saúde, esporte } \\
\text { ou recreação }\end{array}$ \\
\hline $\begin{array}{l}\text { Estados } \\
\text { Unidos }\end{array}$ & $\begin{array}{l}\text { Resíduos Sólidos Urbanos } \\
\text { USEPA, } 1976\end{array}$ & $\begin{array}{l}\text { Os resíduos sólidos urbanos } \\
\text { (também chamados de lixo) são } \\
\text { definidos em nível nacional como } \\
\text { resíduos consistindo em itens do } \\
\text { dia-a-dia, tais como embalagens } \\
\text { de produtos, restos de grama, } \\
\text { móveis, roupas, garrafas e latas, } \\
\text { restos de comida, jornais, } \\
\text { eletrodomésticos, eletrônicos de } \\
\text { consumo e baterias. São } \\
\text { originados em casas, instituições } \\
\text { como escolas e hospitais e fontes } \\
\text { comerciais como restaurantes e } \\
\text { pequenas empresas. } \\
\text { A definição da USEPA de resíduos } \\
\text { sólidos urbanos ou municipality } \\
\text { solid waste para o termo em inglês } \\
\text { (MSW) não inclui lodos de } \\
\text { tratamento de águas residuais } \\
\text { municipais, resíduos de processos } \\
\text { industriais, partes de automóveis, } \\
\text { cinzas de combustão ou detritos } \\
\text { de construção civil e demolição }\end{array}$ \\
\hline $\begin{array}{l}\text { União } \\
\text { Européia }\end{array}$ & $\begin{array}{l}\text { Resíduos Sólidos Urbanos } \\
\text { EEA, } 2013\end{array}$ & $\begin{array}{l}\text { os resíduos sólidos urbanos são } \\
\text { produzidos principalmente por } \\
\text { famílias, embora resíduos } \\
\text { similares gerados no comércio, } \\
\text { escritórios e instituições públicas } \\
\text { também estão incluídos }\end{array}$ \\
\hline
\end{tabular}




\subsection{APÊNDICE 2: CONTATOS REALIZADOS COM INSTITUIÇÕES DE RESÍDUOS SÓLIDOS NOS MUNICÍPIOS ESTUDADOS}

\begin{tabular}{|c|c|c|c|c|}
\hline Município & Data & Para & Solicitação & Resultado \\
\hline $\begin{array}{l}\text { São } \\
\text { Francisco }\end{array}$ & $29 / 01 / 17$ & $\begin{array}{l}\text { San Francisco } \\
\text { Environmental } \\
\text { Department }\end{array}$ & Visita técnica e entrevista & sem retorno \\
\hline $\begin{array}{l}\text { São } \\
\text { Francisco }\end{array}$ & $15 / 01 / 17$ & $\begin{array}{l}\text { San Francisco } \\
\text { Environmental } \\
\text { Department }\end{array}$ & Visita técnica e entrevista & sem retorno \\
\hline $\begin{array}{l}\text { São } \\
\text { Francisco }\end{array}$ & $25 / 03 / 18$ & Recology & $\begin{array}{l}\text { Dados quantitativos da } \\
\text { reciclagem }\end{array}$ & $\begin{array}{l}\text { informações } \\
\text { parcialmente } \\
\text { recebidas em } \\
26 / 03 / 18\end{array}$ \\
\hline $\begin{array}{l}\text { São } \\
\text { Francisco }\end{array}$ & $27 / 03 / 18$ & $\begin{array}{l}\text { San Francisco } \\
\text { Environmental } \\
\text { Department }\end{array}$ & $\begin{array}{l}\text { Dados quantitativos da } \\
\text { reciclagem }\end{array}$ & sem retorno \\
\hline São Paulo & $15 / 03 / 17$ & $\begin{array}{l}\text { AMLURB, } \\
\text { assessoria } \\
\text { imprensa }\end{array}$ & $\begin{array}{l}\text { Entrevista com } \\
\text { Departamento que } \\
\text { gerencia coleta seletiva } \\
\text { com cooperativas e } \\
\text { associações }\end{array}$ & $\begin{array}{l}\text { retorno em } \\
27 / 03 / 17, \\
\text { confirmando } \\
\text { agendamento }\end{array}$ \\
\hline São Paulo & $6 / 4 / 2017$ & $\begin{array}{l}\text { AMLURB, } \\
\text { Departamento } \\
\text { que gerencia } \\
\text { coleta seletiva } \\
\text { com } \\
\text { cooperativas e } \\
\text { associações }\end{array}$ & $\begin{array}{l}\text { Solicitação de dados: tipo } \\
\text { de apoio às cooperativas } \\
\text { e associações }\end{array}$ & $\begin{array}{l}\text { retorno em } \\
\text { 05/05/17, } \\
\text { informando que } \\
\text { ainda não tem as } \\
\text { informações } \\
\text { solicitadas }\end{array}$ \\
\hline São Paulo & $15 / 08 / 17$ & $\begin{array}{l}\text { AMLURB, } \\
\text { Departamento } \\
\text { que gerencia } \\
\text { coleta seletiva } \\
\text { com } \\
\text { cooperativas e } \\
\text { associações }\end{array}$ & $\begin{array}{l}\text { Nova solicitação para as } \\
\text { mesmas informações }\end{array}$ & $\begin{array}{l}\text { Em 24/08/17, } \\
\text { AMLURB } \\
\text { repassa a } \\
\text { solicitação das } \\
\text { informações mas } \\
\text { sem envio de } \\
\text { dados solicitados }\end{array}$ \\
\hline São Paulo & $22 / 03 / 18$ & $\begin{array}{l}\text { AMLURB, } \\
\text { Assessoria de } \\
\text { Imprensa }\end{array}$ & $\begin{array}{l}\text { Nova solicitação de } \\
\text { informações sobre as } \\
\text { quantiades de residuos } \\
\text { reciclaveis recebidas nas } \\
\text { coopertativas/associações } \\
\text { e CMTs }\end{array}$ & sem retorno \\
\hline $\begin{array}{l}\text { Cidade do } \\
\text { Cabo }\end{array}$ & $15 / 01 / 17$ & $\begin{array}{l}\text { Departamento } \\
\text { de Residuos } \\
\text { Sólidos }\end{array}$ & Visita técnica e entrevista & sem retorno \\
\hline $\begin{array}{l}\text { Cidade do } \\
\text { Cabo }\end{array}$ & $24 / 01 / 17$ & $\begin{array}{l}\text { Solicitação no } \\
\text { site da } \\
\text { Prefeitura da }\end{array}$ & $\begin{array}{l}\text { Novo envio de solicitação } \\
\text { para visita técnica e } \\
\text { entrevista }\end{array}$ & sem retorno \\
\hline
\end{tabular}




\begin{tabular}{|c|c|c|c|c|}
\hline Município & Data & Para & Solicitação & Resultado \\
\hline & & $\begin{array}{l}\text { Cidade do } \\
\text { Cabo }\end{array}$ & & \\
\hline $\begin{array}{l}\text { Cidade do } \\
\text { Cabo }\end{array}$ & $25 / 01 / 17$ & $\begin{array}{l}\text { Solicitação } \\
\text { para outro } \\
\text { responsável } \\
\text { pelo } \\
\text { Departamento } \\
\text { de Resíduos } \\
\text { Sólidos }\end{array}$ & $\begin{array}{l}\text { Novo envio de solicitação } \\
\text { para visita técnica e } \\
\text { entrevista }\end{array}$ & sem retorno \\
\hline $\begin{array}{l}\text { Cidade do } \\
\text { Cabo }\end{array}$ & $27 / 01 / 17$ & $\begin{array}{l}\text { Solicitação no } \\
\text { site da } \\
\text { Prefeitura da } \\
\text { Cidade do } \\
\text { Cabo }\end{array}$ & $\begin{array}{l}\text { Novo envio de solicitação } \\
\text { para visita técnica e } \\
\text { entrevista }\end{array}$ & $\begin{array}{l}\text { Solicitação } \\
\text { repassada para } \\
\text { outros } \\
\text { responsáveis em } \\
30 / 01 / 17\end{array}$ \\
\hline $\begin{array}{l}\text { Cidade do } \\
\text { Cabo }\end{array}$ & $27 / 01 / 18$ & REGENIZE & Entrevista & $\begin{array}{l}\text { Entrevista } \\
\text { realizada } \\
05 / 03 / 18\end{array}$ \\
\hline $\begin{array}{l}\text { Cidade do } \\
\text { Cabo }\end{array}$ & $27 / 01 / 18$ & MrRecycle & Entrevista & $\begin{array}{l}\text { Respondeu em } \\
27 / 01 / 18 \text { mas } \\
\text { não esteve } \\
\text { disponível para } \\
\text { entrevista }\end{array}$ \\
\hline $\begin{array}{l}\text { Cidade do } \\
\text { Cabo }\end{array}$ & $27 / 01 / 18$ & Green Cape & Entrevista & $\begin{array}{l}\text { Entrevista } \\
\text { realizada } \\
07 / 03 / 18\end{array}$ \\
\hline $\begin{array}{l}\text { Cidade do } \\
\text { Cabo }\end{array}$ & $27 / 01 / 18$ & $\begin{array}{l}\text { Pesquisador } \\
\text { na } \\
\text { Universidade } \\
\text { de Cape Town }\end{array}$ & Entrevista & $\begin{array}{l}\text { Não esteve } \\
\text { disponível no } \\
\text { período }\end{array}$ \\
\hline $\begin{array}{l}\text { Cidade do } \\
\text { Cabo }\end{array}$ & $27 / 01 / 18$ & $\begin{array}{l}\text { Nova } \\
\text { solicitação } \\
\text { para o } \\
\text { Departamento } \\
\text { de Resíduos } \\
\text { Sólidos da } \\
\text { Cidade do } \\
\text { Cabo }\end{array}$ & Visita técnica e entrevista & $\begin{array}{l}\text { Solicitação } \\
\text { repassada para } \\
\text { outros } \\
\text { responsáveis em } \\
29 / 01 / 18 \text {. } \\
\text { Resposta em } \\
29 / 01 / 18 \\
\text { informando que } \\
\text { solicitou } \\
\text { autorização do } \\
\text { Diretor do } \\
\text { Departamento } \\
\text { para as visitas e } \\
\text { entrevistas }\end{array}$ \\
\hline $\begin{array}{l}\text { Cidade do } \\
\text { Cabo }\end{array}$ & $12 / 1 / 2018$ & -- & -- & $\begin{array}{l}\text { Confirmada as } \\
\text { visitas técnicas e } \\
\text { entrevistas }\end{array}$ \\
\hline
\end{tabular}




\begin{tabular}{|l|c|l|l|l|}
\hline Município & Data & \multicolumn{1}{|c|}{ Para } & Solicitação & Resultado \\
\hline $\begin{array}{l}\text { Cidade do } \\
\text { Cabo }\end{array}$ & $\begin{array}{l}\text { Nova } \\
\text { solicitação } \\
\text { para o } \\
\text { Departamento } \\
\text { de Resíduos } \\
\text { Sólidos }\end{array}$ & dados quantitativos & sem retorno \\
\hline
\end{tabular}




\subsection{APÊNDICE 3: ROTEIRO DE ENTREVISTAS}

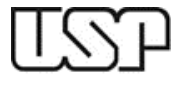

Waste Recycling Public Polities:

a comparative study of San Francisco, USA, São Paulo, Brazil and Cape Town, South

Africa

\section{APÊNDICE - ROTEIRO DE PESQUISA}

DATA

MUNICIPIO

NONE DO DEPARTAMENTO/INSTITUICAO

\section{ENTREVISTADO}

NOME

EMAIL E TELEFONE

\begin{tabular}{|c|c|}
\hline \multirow[t]{8}{*}{1} & $\begin{array}{l}\text { Quais são os resíduos que compõem os Resíduos Sólidos Urbanos - } \\
\text { RSU para a cidade? (assinale com "x". Pode ser assinalada mais de } \\
\text { uma resposta) }\end{array}$ \\
\hline & $\begin{array}{l}\text { Domiciliar: restos de comida, embalagens, objetos inteiros } \\
\text { descartados, pedaços de objetivos, papel higiênico, poda de jardins, } \\
\text { etc. }\end{array}$ \\
\hline & Varrição das ruas e limpeza de espaços públicos \\
\hline & Limpeza e desobstrução de sistemas de drenagem \\
\hline & $\begin{array}{l}\text { Entulho de reformas de domicílios e pequenos comércios de pequenos } \\
\text { geradores }\end{array}$ \\
\hline & Material de podas das áreas verdes \\
\hline & Limpeza de mercados e feiras livres \\
\hline & $\begin{array}{l}\text { Resíduos de estabelecimentos comerciais e serviços de pequenos } \\
\text { geradores }\end{array}$ \\
\hline & Outro. Por favor, especificar: \\
\hline \multirow[t]{3}{*}{2} & $\begin{array}{l}\text { Quais são os resíduos que compõem os Resíduos Sólidos } \\
\text { Domiciliares - RSD para a cidade? (assinale com " } x \text { ". Pode ser } \\
\text { assinalada mais de uma resposta) }\end{array}$ \\
\hline & Orgânicos: restos de comida, cascas de frutas, pó café, etc. \\
\hline & Orgânicos: poda de jardins \\
\hline
\end{tabular}




\begin{tabular}{|c|c|c|}
\hline & \multicolumn{2}{|c|}{$\begin{array}{l}\text { Embalagens em geral: caixas, latas, películas plásticas, embalagens } \\
\text { PETs, etc. }\end{array}$} \\
\hline & \multicolumn{2}{|l|}{ Papel higiênico } \\
\hline & \multicolumn{2}{|l|}{ Fralda descartável } \\
\hline & \multicolumn{2}{|l|}{ Remédios } \\
\hline & \multicolumn{2}{|c|}{ Restos de produtos limpeza e suas embalagens } \\
\hline & \multicolumn{2}{|l|}{ Pilhas e baterias } \\
\hline & \multicolumn{2}{|c|}{ Objetos em desuso ou partes, sem utilidade para o usuário } \\
\hline & \multicolumn{2}{|c|}{ Móveis ou parte de móveis, sem utilidade pelo usuário } \\
\hline & \multirow{2}{*}{\multicolumn{2}{|c|}{$\begin{array}{l}\text { Eletroeletrônicos: TVs, aparelho celular, computadores, radio, } \\
\text { geladeira, microondas, etc. } \\
\text { Outro. Por favor, especificar: }\end{array}$}} \\
\hline & & \\
\hline 3 & \multicolumn{2}{|c|}{$\begin{array}{l}\text { Pode disponibilizar algum relatório e/ou estudo que contenha a } \\
\text { composição gravimétrica dos RSU e RSD? }\end{array}$} \\
\hline 4 & \multicolumn{2}{|c|}{$\begin{array}{l}\text { A coleta de RSD segregado abrange todo território da cidade? (assinale } \\
\text { com "x") }\end{array}$} \\
\hline & \multicolumn{2}{|c|}{$\begin{array}{l}\text { Sim } \\
\text { OBS: os contratos de concessões das concessionárias que executam a } \\
\text { CS são obrigados a universalizar os serviços, ENTRETANTO, a adesão } \\
\text { da população é reduzida }\end{array}$} \\
\hline & \multicolumn{2}{|c|}{ Não. Se não, qual o percentual (\%)?___ (área ou quantidade) } \\
\hline \multirow[t]{8}{*}{5} & \multicolumn{2}{|c|}{$\begin{array}{l}\text { Quem faz a coleta de RSD na cidade? (assinale com " } x " \text {. Pode assinalar } \\
\text { mais de uma opção) }\end{array}$} \\
\hline & EXECUTOR & BAIRRO/DISTRITO/SETOR \\
\hline & Empresa privada contratada & Sem informação \\
\hline & Empresa pública & \\
\hline & ONGs & \\
\hline & Catadores autônomos & \\
\hline & $\begin{array}{l}\text { Cooperativas e/ou associações de } \\
\text { catadores }\end{array}$ & Sem informação \\
\hline & Outro. Por favor, especificar: & \\
\hline 6 & \multicolumn{2}{|c|}{$\begin{array}{l}\text { Qual a quantidade (toneladas) total de RSU e de RSD que foi coletada } \\
\text { nos últimos } 10 \text { anos para a cidade, por ano? }\end{array}$} \\
\hline ANO & \multicolumn{2}{|l|}{ RSU } \\
\hline
\end{tabular}




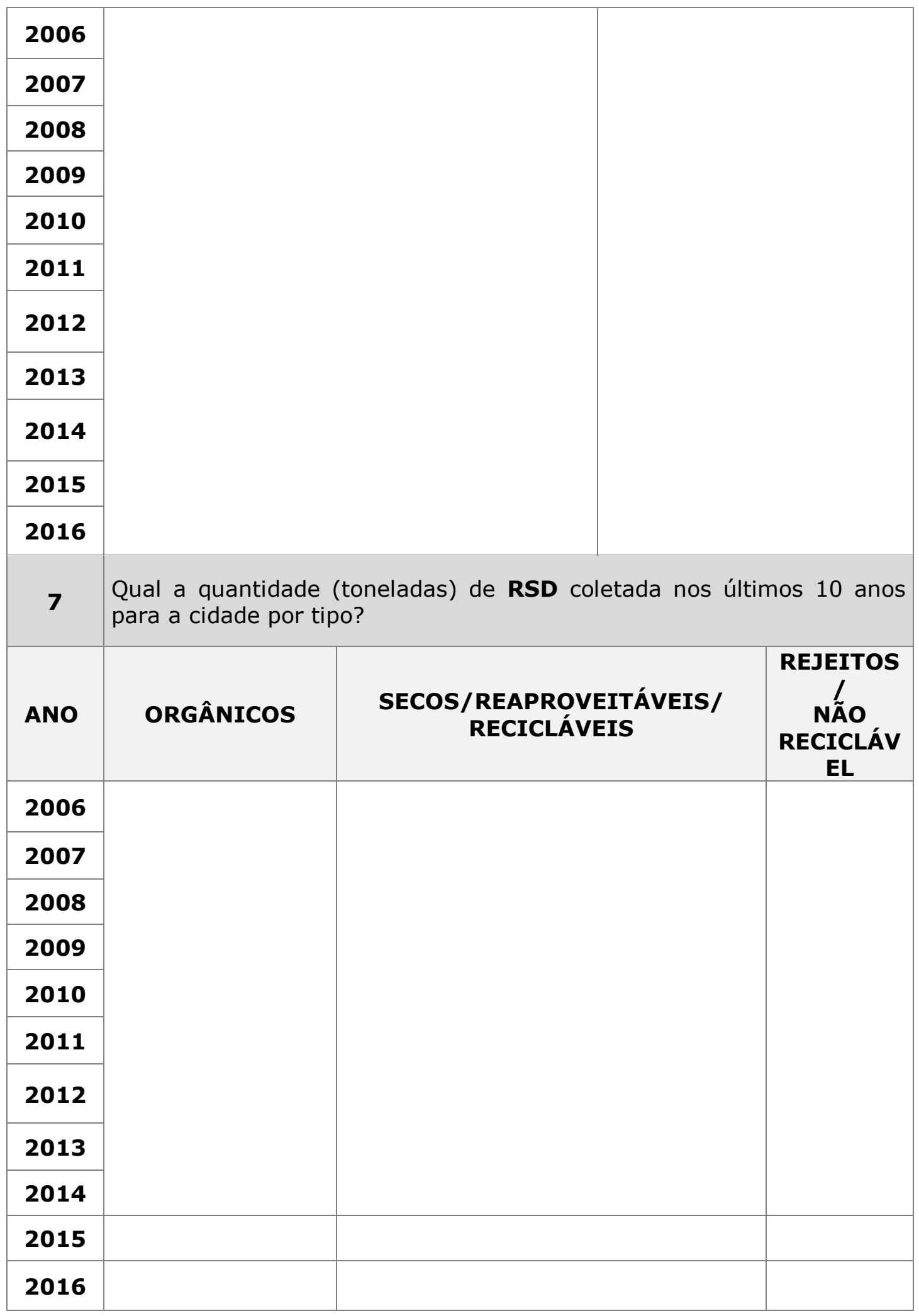




\begin{tabular}{|c|c|c|c|c|c|c|}
\hline 8 & \multicolumn{6}{|c|}{ Como é feita a coleta de RSD na cidade? (assinale com "x") } \\
\hline & \multicolumn{6}{|c|}{ Não há separação dos resíduos sólidos domiciliares } \\
\hline & \multicolumn{6}{|c|}{$\begin{array}{l}\text { São coletados } 2 \text { tipos de resíduos: orgânicos e } \\
\text { secos/reaproveitáveis/recicláveis. } \\
\text { O caminhão do lixo coleta os resíduos domiciliares orgânicos num dia e } \\
\text { em outro dia, os secos/reaproveitáveis/recicláveis }\end{array}$} \\
\hline & \multicolumn{6}{|c|}{$\begin{array}{l}\text { São coletados } 2 \text { tipos de resíduos. orgânicos e } \\
\text { secos/reaproveitáveis/recicláveis. } \\
\text { Os recipientes de acondicionamento de lixo são diferentes: um para } \\
\text { orgânicos, outro para materiais secos/reaproveitáveis/recicláveis } \\
\text { O caminhão do lixo coleta ambos resíduos, mas tem compartimento na } \\
\text { caçamba que permite separar os tipos de resíduos }\end{array}$} \\
\hline & \multicolumn{6}{|c|}{$\begin{array}{l}\text { São coletados } 3 \text { tipos de resíduos: orgânicos, } \\
\text { secos/reaproveitáveis/recicláveis, rejeitos/não recicláveis } \\
\text { Existe um caminhão de lixo que coleta cada tipo de resíduos em dias } \\
\text { diferentes }\end{array}$} \\
\hline & \multicolumn{6}{|c|}{$\begin{array}{l}\text { São coletados } 3 \text { tipos de resíduos: orgânicos, } \\
\text { secos/reaproveitáveis/recicláveis, rejeitos/não recicláveis } \\
\text { O caminhão do lixo coleta todos os resíduos, mas tem compartimento } \\
\text { na caçamba que permite armazenar separadamente os } 3 \text { tipos de } \\
\text { resíduos }\end{array}$} \\
\hline & \multicolumn{6}{|c|}{$\begin{array}{l}\text { Outro. Por favor, especificar: } \\
\text { São coletados } 2 \text { tipos de resíduos: secos/reaproveitáveis/recicláveis e } \\
\text { os demais resíduos que são enviados para aterros sanitários. Os } \\
\text { recicláveis são enviados para CMTs ou cooperativas }\end{array}$} \\
\hline 9 & \multicolumn{6}{|c|}{$\begin{array}{l}\text { Descreva suscintamente a evolução da coleta de RSD segregados em: } \\
\text { orgânicos e secos/reaproveitáveis/recicláveis, rejeitos/não recicláveis } \\
\text { na cidade }\end{array}$} \\
\hline 10 & \multicolumn{6}{|c|}{$\begin{array}{l}\text { Qual foi o tratamento e/ou disposição final dos resíduos sólidos } \\
\text { domiciliares nos últimos anos? }\end{array}$} \\
\hline ANO & TOTAL & $\begin{array}{c}\text { Aterro } \\
\text { Sanitário }\end{array}$ & $\begin{array}{l}\text { Central de } \\
\text { Triagem }\end{array}$ & $\begin{array}{l}\text { Industria } \\
\text { Recicladora }\end{array}$ & Exportação & Outro \\
\hline \multicolumn{7}{|l|}{2006} \\
\hline 2007 & & & & & & \\
\hline
\end{tabular}




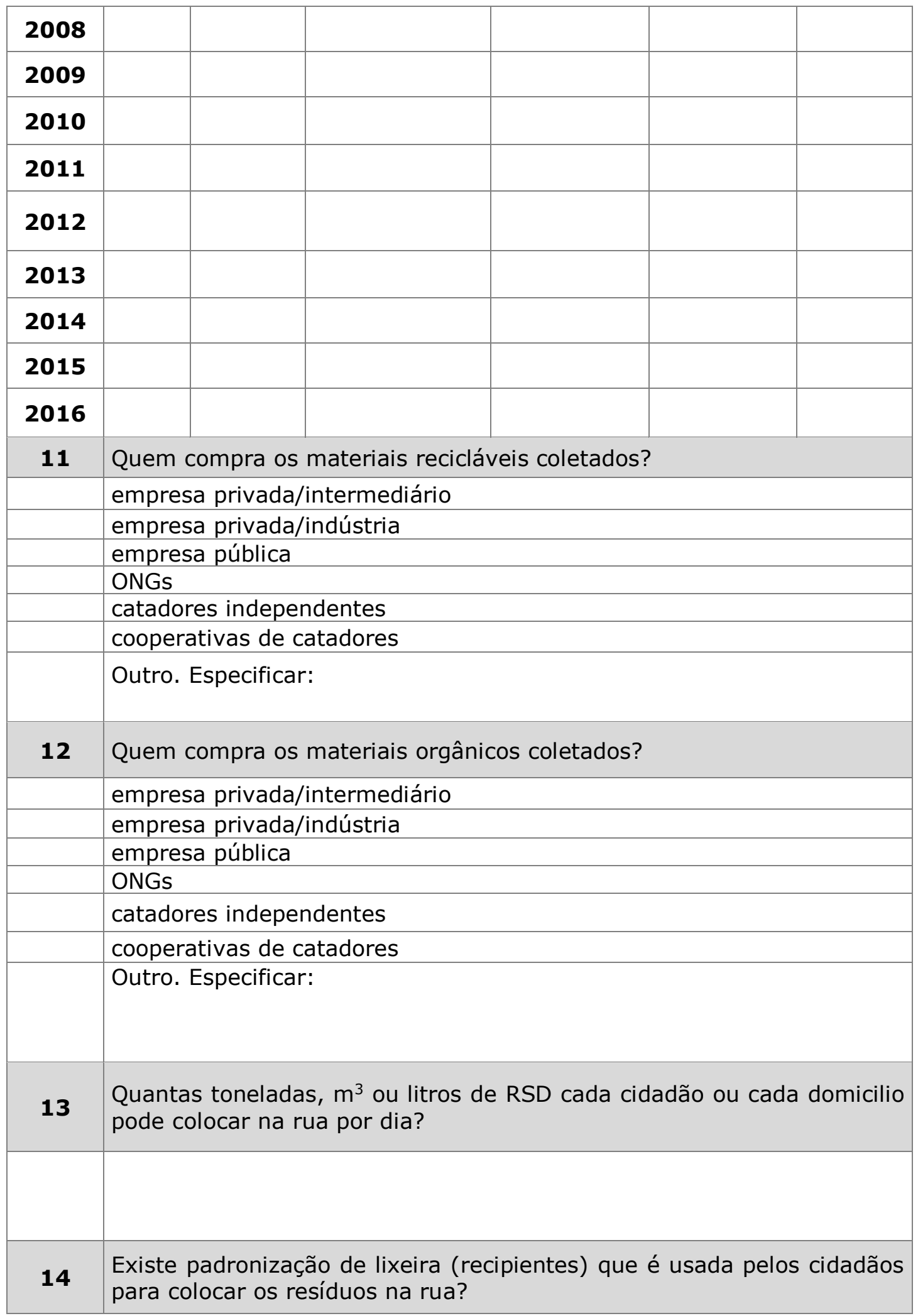




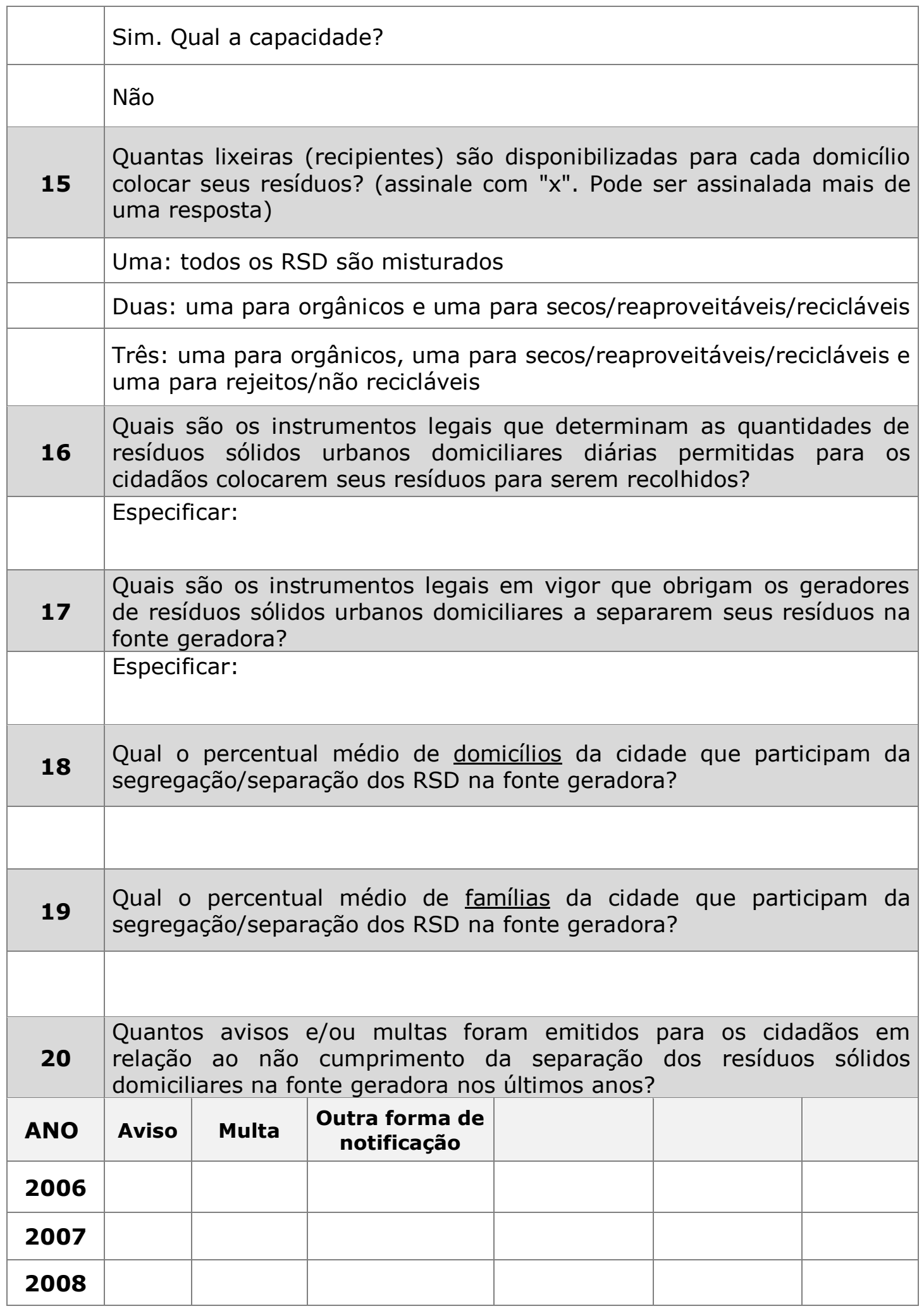




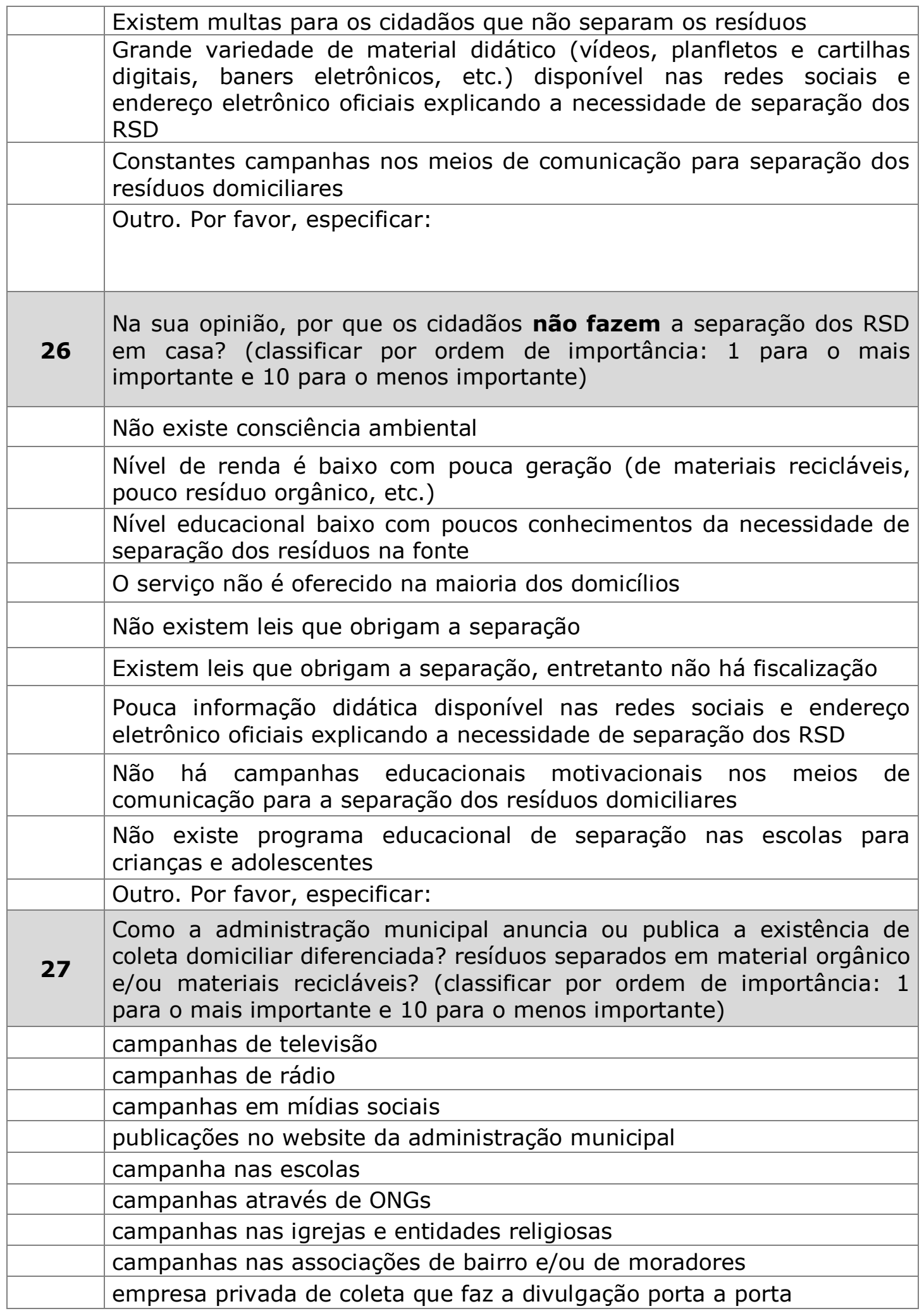




\begin{tabular}{|c|c|c|c|}
\hline & \multicolumn{3}{|l|}{ Outro. Por favor, especificar: } \\
\hline \multirow[t]{2}{*}{28} & \multicolumn{3}{|c|}{$\begin{array}{l}\text { Quais distritos ou bairros são mais participativos na separação materia } \\
\text { orgânico e/ou materiais recicláveis? }\end{array}$} \\
\hline & \multicolumn{3}{|l|}{ Por favor, especificar: } \\
\hline \multirow[t]{13}{*}{29} & \multicolumn{3}{|c|}{$\begin{array}{l}\text { Quais as razões para os distritos ou bairros serem mais participativos } \\
\text { na separação dos resíduos domiciliares? }\end{array}$} \\
\hline & \multicolumn{3}{|c|}{$\begin{array}{l}\text { Grande quantidade de materiais recicláveis e orgânicos na casa dos } \\
\text { cidadãos }\end{array}$} \\
\hline & \multirow{2}{*}{\multicolumn{3}{|c|}{$\begin{array}{l}\text { pouca quantidade de materiais recicláveis e orgânicos na casa dos } \\
\text { cidadãos } \\
\text { alta renda familiar }\end{array}$}} \\
\hline & & & \\
\hline & \multicolumn{3}{|l|}{ baixa renda familiar } \\
\hline & \multicolumn{3}{|c|}{ alto nível de escolaridade dos cidadãos } \\
\hline & \multicolumn{3}{|c|}{ baixo nível de escolaridade dos cidadãos } \\
\hline & \multicolumn{3}{|c|}{ mais caminhões de lixo e mais lixeiros nesta região } \\
\hline & \multicolumn{3}{|c|}{ menos caminhões de lixo e mais lixeiros nesta região } \\
\hline & \multicolumn{3}{|c|}{ fácil acesso para os caminhões de lixo } \\
\hline & \multicolumn{3}{|c|}{ difícil acesso para os caminhões de lixo } \\
\hline & \multicolumn{3}{|c|}{ ONGs fazem a coleta de materiais recicláveis } \\
\hline & \multicolumn{3}{|c|}{ catadores fazem a coleta de materiais recicláveis } \\
\hline \multirow[t]{3}{*}{30} & \multicolumn{3}{|c|}{$\begin{array}{l}\text { Como a administração municipal remunera as empresas e outros que } \\
\text { fazem a coleta seletiva de resíduos sólidos urbanos domiciliares? }\end{array}$} \\
\hline & \multirow[b]{2}{*}{ Executor } & \multicolumn{2}{|c|}{ Forma de Pagamento } \\
\hline & & Kg/tonelada & $\begin{array}{l}\text { Outro } \\
\text { (Especificar } \\
\text { ) }\end{array}$ \\
\hline \multirow[t]{6}{*}{$x$} & \multicolumn{3}{|l|}{ Empresa privada contratada } \\
\hline & \multicolumn{3}{|l|}{ Empresa pública } \\
\hline & \multicolumn{3}{|l|}{ ONGs } \\
\hline & \multicolumn{3}{|l|}{ Catadores independentes } \\
\hline & \multicolumn{3}{|l|}{ Cooperativas de catadores } \\
\hline & \multicolumn{3}{|l|}{ Outros. Especificar: } \\
\hline \multirow[t]{2}{*}{31} & \multicolumn{3}{|c|}{$\begin{array}{l}\text { Existe uma taxa específica para os serviços de resíduos sólidos } \\
\text { urbanos? }\end{array}$} \\
\hline & \multicolumn{3}{|l|}{ Sim } \\
\hline $\mathrm{x}$ & \multicolumn{3}{|l|}{ Não } \\
\hline 32 & $\begin{array}{l}\text { Se você respondeu sim para a } \\
\text { cobrado nesta taxa? }\end{array}$ & pergunta anterior, que & tipo de serviço é \\
\hline & Coleta de resíduos domiciliares & & \\
\hline
\end{tabular}




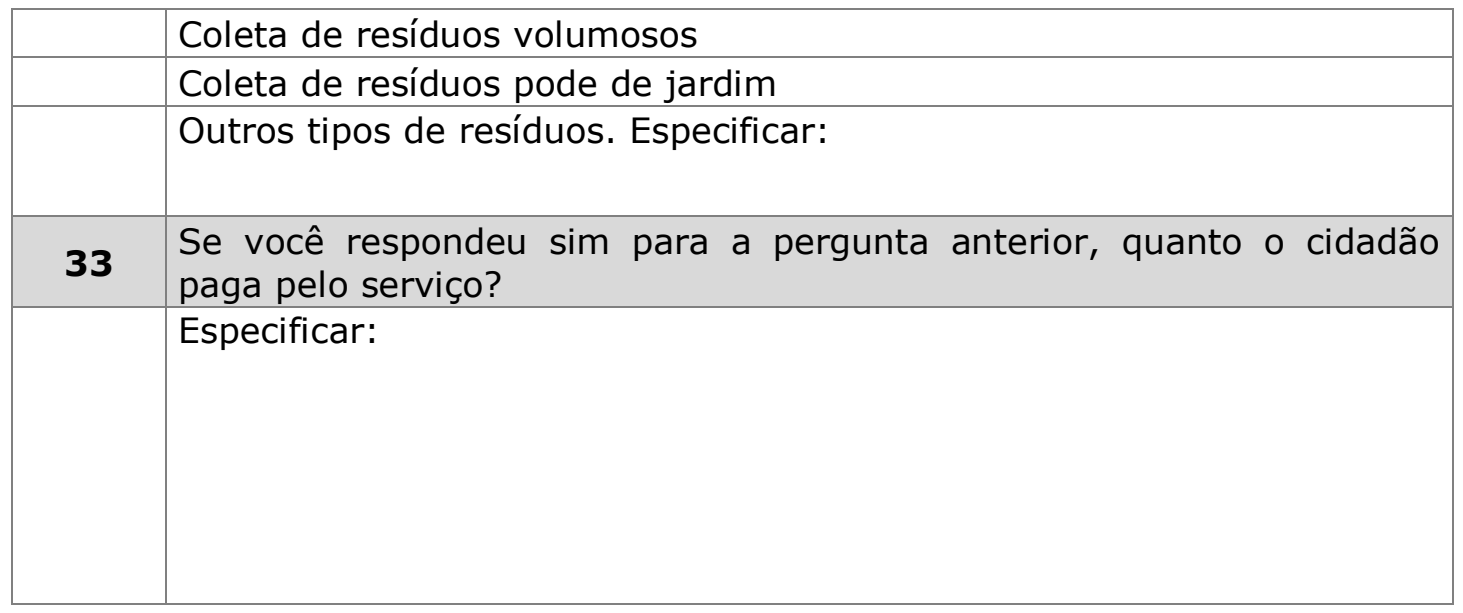

Outras informações que julgar relevante comentar: 


\subsection{APÊNDICE 4: DATAS DOS LEVANTAMENTOS DE CAMPO POR MUNICÍPIO}

\begin{tabular}{|c|c|c|c|}
\hline Município & Data & $\begin{array}{c}\text { Tipo de } \\
\text { Levantamento }\end{array}$ & Local e Instituição \\
\hline $\begin{array}{l}\text { São } \\
\text { Francisco }\end{array}$ & $09 / 07 / 14$ & Visita técnica & $\begin{array}{l}\text { Recology. Recycle Central at Pier } \\
96, \text { central de triagem de resíduos } \\
\text { sólidos urbanos recicláveis/secos }\end{array}$ \\
\hline $\begin{array}{l}\text { São } \\
\text { Francisco }\end{array}$ & $09 / 07 / 14$ & Visita técnica & $\begin{array}{l}\text { Recology. Recycle Central at Pier } \\
96, \text { central de recepção de resíduos } \\
\text { orgânicos }\end{array}$ \\
\hline $\begin{array}{l}\text { Cidade do } \\
\text { Cabo }\end{array}$ & $27 / 02 / 18$ & Visita técnica & $\begin{array}{l}\text { Coastal Park Landifill, aterro } \\
\text { sanitário }\end{array}$ \\
\hline $\begin{array}{l}\text { Cidade do } \\
\text { Cabo }\end{array}$ & $27 / 02 / 18$ & Visita técnica & $\begin{array}{l}\text { Kraainfontein Waste Managment, } \\
\text { central de triagem de resíduos } \\
\text { sólidos urbanos recicláveis/secos }\end{array}$ \\
\hline $\begin{array}{l}\text { Cidade do } \\
\text { Cabo }\end{array}$ & $27 / 02 / 18$ & Visita técnica & $\begin{array}{l}\text { Kraaifontein Drop Off, ponto de } \\
\text { entrega voluntária de resíduos } \\
\text { sólidos }\end{array}$ \\
\hline $\begin{array}{l}\text { Cidade do } \\
\text { Cabo }\end{array}$ & $28 / 02 / 18$ & Visita técnica & $\begin{array}{l}\text { Muizenberg Drop Off, ponto de } \\
\text { entrega voluntária de resíduos } \\
\text { sólidos }\end{array}$ \\
\hline $\begin{array}{l}\text { Cidade do } \\
\text { Cabo }\end{array}$ & $28 / 02 / 18$ & Visita técnica & $\begin{array}{l}\text { Reliance Muizenberg, ponto de } \\
\text { recepção de resíduos orgânicos de } \\
\text { poda para trituração e posterior } \\
\text { envio para compostagem }\end{array}$ \\
\hline $\begin{array}{l}\text { Cidade do } \\
\text { Cabo }\end{array}$ & 02/03/18 & Entrevista & $\begin{array}{l}\text { Solid Waste Department. City of } \\
\text { Cape Town, Setor de minimização } \\
\text { de resíduos }\end{array}$ \\
\hline $\begin{array}{l}\text { Cidade do } \\
\text { Cabo }\end{array}$ & $05 / 03 / 18$ & Entrevista & $\begin{array}{l}\text { Regenize, empresa de pequeno } \\
\text { porte que executa coleta de } \\
\text { resíduos sólidos recicláveis/secos }\end{array}$ \\
\hline $\begin{array}{l}\text { Cidade do } \\
\text { Cabo }\end{array}$ & $07 / 03 / 18$ & Entrevista & $\begin{array}{l}\text { Green Cape, Waste Sector Desk. } \\
\text { Organização Não Governamental } \\
\text { (ONG) que promove negócios } \\
\text { ecológicos para toda a província de } \\
\text { Western Cape }\end{array}$ \\
\hline São Paulo & $01 / 09 / 17$ & Visita técnica & $\begin{array}{l}\text { COOPERE - Cooperativa de } \\
\text { Catadores (Ponte Pequena) }\end{array}$ \\
\hline São Paulo & $27 / 04 / 17$ & Visita técnica & $\begin{array}{l}\text { Central Mecanizada de Triagem } \\
\text { Ponte Pequena, operada pela } \\
\text { LOGA }\end{array}$ \\
\hline São Paulo & $25 / 02 / 17$ & Visita técnica & $\begin{array}{l}\text { Central Mecanizada de Triagem } \\
\text { Carolina Maria de Jesus, operada } \\
\text { pela ECOURBIS }\end{array}$ \\
\hline São Paulo & $01 / 02 / 17$ & Entrevista & $\begin{array}{l}\text { AMLURB, Diretoria de Gestão e } \\
\text { Serviços, obtenção de dados } \\
\text { quantitativos }\end{array}$ \\
\hline São Paulo & $02 / 02 / 17$ & Entrevista & $\begin{array}{l}\text { AMLURB, Diretoria de Planejamento } \\
\text { e Desenvolvimento, coleta seletiva }\end{array}$ \\
\hline
\end{tabular}




\begin{tabular}{|l|c|c|c|}
\hline Município & Data & $\begin{array}{c}\text { Tipo de } \\
\text { Levantamento }\end{array}$ & \multicolumn{1}{|c|}{ Local e Instituição } \\
\hline São Paulo & $03 / 02 / 17$ & Entrevista & $\begin{array}{l}\text { cooperativas } \\
\text { AMLURB, Diretoria de Gestão e } \\
\text { Serviços, coleta seletiva formal }\end{array}$ \\
\hline São Paulo & $03 / 02 / 17$ & Entrevista & $\begin{array}{l}\text { AMLURB, Diretoria de Gestão e } \\
\text { Serviços, experiência compostagem }\end{array}$ \\
\hline São Paulo & $30 / 03 / 17$ & Entrevista & $\begin{array}{l}\text { AMLURB, Diretoria de Planejamento } \\
\text { e Desenvolvimento, coleta seletiva } \\
\text { cooperativas }\end{array}$ \\
\hline
\end{tabular}


10.5 APÊNDICE 5: TRABALHO PUBLICADO EM CONGRESSO INTERNACIONAL DE RESÍDUOS SÓLIDOS 


\title{
PRELIMINARY EVALUATION OF THE PROGRAM GOALS FOR RECYCLED SOLID WASTE IN THE SÃO PAULO MUNICIPALITY, BRAZIL
}

\author{
A. F. BRAGA*, H. RIBEIRO**, WMR. GUNTHER $\cdots$. \\ * Global Health and Sustainability Program, School of Public Health, Environmental \\ Health Department, São Paulo University, Av. Dr. Arnaldo, 715, Säo Paulo, Brazil \\ ** School of Public Health, Environmental Health Department, São Paulo University, Av. \\ Dr. Amaldo, 715, São Paulo, Brazil \\ *** School of Public Health, Environmental Health Department, São Paulo University, \\ Av. Dr. Amaldo, 715, São Paulo, Brazil
}

Abstract: Sao Paulo city produced 5.2 million tons per year of solid waste in 2016 and only $2.38 \%$ were sent to the recycling circuit. This percentage of waste recycling did not meet the goal set by the Municipal Solid Waste Integrated Plan (MSWP) that stated for 2016 a recycling mark of $1,569,500.00$ ton/day and it also fell short of universalizing the selective waste collection in the whole Sao Paulo jurisdiction.

\section{INTRODUCTION}

The recycling of municipal solid waste in developing countries, such as Brazil, is fundamental to minimize the socio-environmental impacts generated by management waste systems and to promote positive impacts such as: contributing to the minimization and generation of the methane gas which is highly polluting and greenhouse gas generated in landfills and dumps; reducing damage to untapped areas in order to extract natural resources; reducing the risk of water and soil resorurces contamination caused by hazardous waste and leachate; improving the socioeconomic position of the waste pickers from the informal sector to have more access to their raw material and provide better working conditions with less risk of exposure; changing consumption habits by buying products that are more durable, and which can be repaired and recycled (UN HABITAT, 2010).

The Municipal Authority Urban Clearing (MAUC) of São Paulo understands recycling as one of the actions to be met for the National Solid Waste Policy and the National Policy of Climate Change and has been working to increase recycling rates, as published in the Municipal Solid Waste Integrated Plan (MSWP).

Therefore, the objective of this paper is to evaluate the achievements of the MAUC goals for recycled solid waste and identify the regions of the municipality that most contribute to the selective collection of this tipe of waste.| 


\section{METHODOLOGY}

\subsection{References Review}

The Municipality Solid Waste Integrated Plan (MSMP) was analyzed to extract the targets for the collection and recycling of municipal solid waste (MSW).

Per capita income data by the Regional City Hall (RCH) was obtained from the SEADE Foundation website, a state entity that produces socioeconomic surveys. The data were available by Municipal Districts (MD) that are smaller territorial units and can be organized in groups that form RCH because their geographical limits are coincident. Thus, it was possible to group the MD's in RCH and obtain the per capita income average value (in Reais - R\$) for the year 2010 from the last Brazilian demographic census taken.

The ArcGis software was used to produce the map showing the amount of recyled solid waste by RCH. The layers of the RCH were obtained on Sa Paulo's City Hall website.

\subsection{Data Collection}

The data collection was obtained from MAUC through an official request in September 2015 and January 2017. The total quantities of municipal solid waste were obtained for 2006 until 2016 by the RCH. The MAUC is responsible for managing the following types of solid waste: household (residential) waste, foods overdue, debris, animals, leatreche, miscellaneous, refuse, trash, waste from transfer station, pruning of trees and gardens, drop-off, urban drainage and streams cleaning activities, cleaning of the waste basin of rainwater cushioning. selective household collection, sweeping of streets, waste from water treatment plants and health service.

The solid waste investigated and tabulated for the purposes of this paper was waste from household and selective collection.

The amount of waste generated per month and year and by MCH was obtained by the Municipal Solid Waste Control System (MSWCS) that is received in the control center, in real time, and all the quantities of municipal solid waste per truck. One hundred and twenty tables of monthly MSW were tabulated to extract the quantities of household solid waste and selective waste collection by RCH per year. This data permitted the identification of the areas that have the best RCH recycling rates in Sảo Paulo area.

The $\mathrm{RCH}$ are formed by smaller planning units and the entire control system of the collection routes for each truck is limited by the RCH boundaries. Thus, it is not possible to establish quantitative data by MD - only by RCH. This incompatibility of boundaries makes it difficult to assess the fulfillment of the targets establishment at MSMP that have been defined by MD.

\section{MUNICIPALITY SOLID WASTE IN SÄO PAULO}

\subsection{Overview}

In 2015, the National Sanitation Information System (NSIS) estimated a generation of 62.5 million tons of municipal solid waste for the Brazil where more than $10 \%$ is sent to open dumps and about $4.7 \%$ is collected selectively for the recycling process. (NSIS, 2015)

Sabo Paulo is the largest city in Latin America (with an estimated population of 12.038 .175 inhabitants in 2016 (IBGE, 2017) and 5.2 millinns tons per year of solid waste ( $8 \%$ of Brazillian 
MSW total), out of which $68 \%$ is of household origin (Figure 1) and where more than $90 \%$ of this waste is sent to landfills and $2.36 \%$ is collected selectively for recycled material recovery.

The municipal solid waste management in São Paulo is done by MAUC and the urban cleaning services cover $98 \%$ of the entire municipal territory.

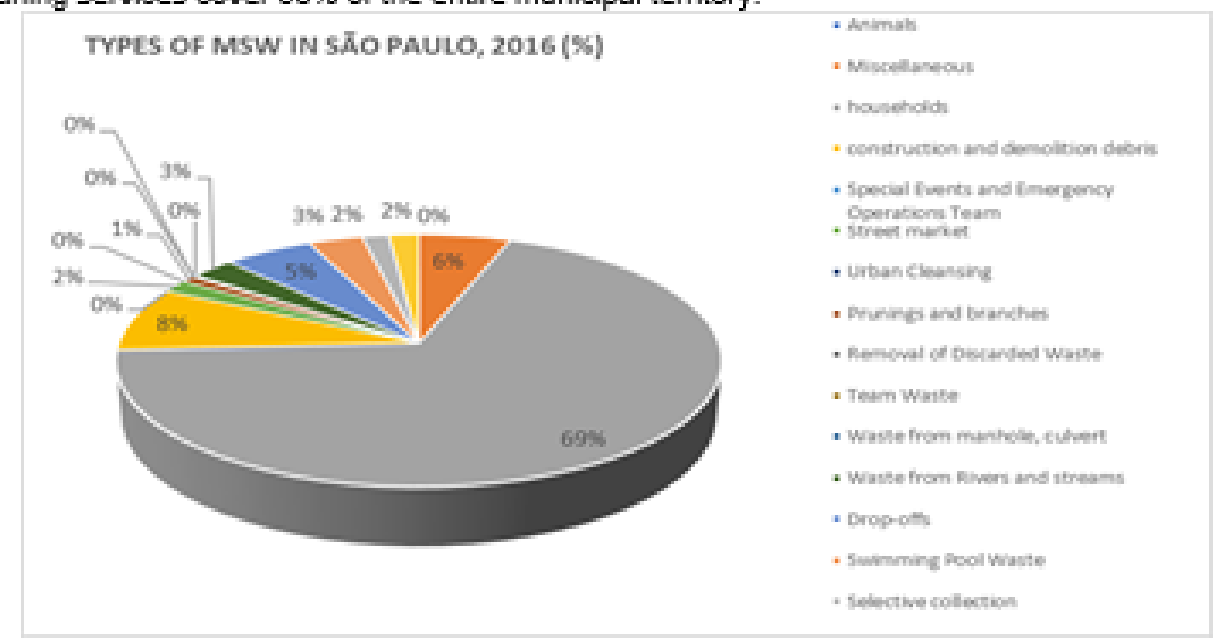

Figure 1. Percentage of municipality solid waste by type in Säo Paulo en 2016.

The public selective waste collection for recycled residential solid waste (papers, plastics, glasses and metals) is executed by: (i) two outsourced firms that collect the waste door to door; (i) 21 sorting centers operated by cooperatives and associations of waste pickers who have an agreement with the MAUC and 20 cooperatives and associations of waste pickers without an agreement with MAUC.

The selective collection of recycled waste in São Paulo is carried out separately from the regular collection and does not cover all households, as in most Brazilian municipalities.

The treatment and final disposal units installed in Săo Paulo are: 2 waste transhipment stations, 2 mechanized waste sorting plants and 41 cooperatives and associations of waste pickers plus 2 sanitary landfills. There is a composting expenimental patio that processes organic solid waste from open market prunings and branches.

No specific law mandates the citizens to separate their waste in the generation places and the expenses with the cleaning service are computed into the urban property and territorial tax.

There is an extended responsibility of manufacturers (extended producer responsibility) under a Federal agreement issued by the Environment Ministry that has provisions for some products: eg. plastic packaging of lubricating oils, batteries, tires, used or contaminated lubricating oil, and agrochemical packaging. There are new agreements that are in progress for: plastic containers of lubricating oil, fluorescent sodium and mercury and mixed-light fluorescent lamps, general packaging, electronic components and their components and medicines.

\subsection{The Goals for recycling at the Municipality Solid Waste Integrated Plan}

In 2014, Săo Paulo City Hall published the Municipal Solid Waste Integrated Plan (MSWP) that defined the goals for management of municipal solid waste until 2032, in order to add to the Solid Waste National Policy $\left(0^{\circ} 12,305 / 2010\right)$ and the goals to reduce the emissions of greenhouse gases as stipulated by the National Policy on Climate Change (n. $\left.{ }^{\circ} 12,187 / 2009\right)$. 
The MSWP had an inclusive approach regarding the National Waste Pickers movement and set ambitious goals for the municipality in order for the selective collection. The targets were:

A. 3,000 tons/day (1,085,000.00 tons/year) for recycled waste from sellective collection and 1,300 tons/day ( $474,500.00$ tons/year) from new units of Biological Mechanical Treatment for organics waste until 2016 (MSMP, 2014: 16).

B. Universalize $100 \%$ of selective collection of dry waste for all Sao Paulo terntory, preceded by campaigns, from 2014 until the end of 2016 (MSWP, 2014: 17).

\section{RESULTS AND DISCUSSION}

The results demonstrated that Sảo Paulo did not reach the MSMP goal A, as showed in Table 1. The initial recycled goal for 2016 was to reach 1,085,000.00 ton of total recycling MSW but only $84,652.56$ tons $(2.36 \%$ ) was in fact collected. Also, the biological treatment units were not installed as planned.

Table 1 Total of household and recycled solid waste collected for Săo Paulo, 2006-2016

\begin{tabular}{|c|r|r|r|r|r|r|}
\hline \multirow{2}{*}{ YEAR } & \multicolumn{7}{|c|}{ MSW PER YEAR (t) } \\
\cline { 2 - 7 } & TOTAL MSW $(t)$ & $\%$ & $\begin{array}{c}\text { HOUSEHOLD } \\
(t)\end{array}$ & $\%$ & $\begin{array}{c}\text { RECYCLED } \\
\text { SOLID WASTE } \\
\text { COLLECTED (t) }\end{array}$ & $\begin{array}{c}\% \text { OF } \\
\text { TOTAL } \\
\text { MSW }\end{array}$ \\
\hline 2006 & $5,312,902.56$ & $100 \%$ & $3,345,506.77$ & $63 \%$ & $22,901.74$ & $0.43 \%$ \\
\hline 2007 & $5,599,850.77$ & $100 \%$ & $3,315,734.46$ & $59 \%$ & $30,120.97$ & $0.54 \%$ \\
\hline 2008 & $5,905,153.66$ & $100 \%$ & $3,454,312.34$ & $59 \%$ & $40,965.37$ & $0.69 \%$ \\
\hline 2009 & $6,403,564.51$ & $100 \%$ & $3,627,798.35$ & $57 \%$ & $34,263.85$ & $0.54 \%$ \\
\hline 2010 & $5,930,517.29$ & $100 \%$ & $3,417,969.63$ & $59 \%$ & $33,076.73$ & $0.56 \%$ \\
\hline 2011 & $5,622,013.69$ & $100 \%$ & $3,479,114.43$ & $62 \%$ & $44,590.56$ & $0.79 \%$ \\
\hline 2012 & $6,429,261.64$ & $100 \%$ & $3,799,597.14$ & $59 \%$ & $56,918.08$ & $0.89 \%$ \\
\hline 2013 & $6,009,028.04$ & $100 \%$ & $3,831,455.19$ & $64 \%$ & $66,439.39$ & $1.11 \%$ \\
\hline 2014 & $5,234,411.31$ & $100 \%$ & $3,495,732.17$ & $67 \%$ & $60,586.50$ & $1.73 \%$ \\
\hline 2015 & $5,527,293.96$ & $100 \%$ & $3,800,496.39$ & $69 \%$ & $86,843.25$ & $2.29 \%$ \\
\hline 2016 & $5,230,713.63$ & $100 \%$ & $3,595,560.03$ & $69 \%$ & $84,652.56$ & $2.36 \%$ \\
\hline AVERAGE & $5,745,881.90$ & $100 \%$ & $3,559,389.72$ & $62 \%$ & $51,032.64$ & $1.08 \%$ \\
\hline
\end{tabular}

As shown in Table 1, from 2014 to 2016, the total amount of MSW decreased probably due to the Brazilian economic crisis. However, the amount of recycled materials in 2014 (60,586 ton) increased almost $70 \%$ in 2015 ( 86,843 ton). This increase is probably associated with the launching of two mechanized sorting plants. Perhaps, Săo Paulo is still far from achieving good recycling rates for its 9,823 tons of household waste produced daily.

The Goal B of universalizing $100 \%$ of selective collection for household recycled waste for the whole territory was not fulfilled as shown in Table 2 and Figure 1. The maximum value of the recycled solid waste recovery was $10 \%$ for the $\mathrm{RCH}$ of Vila Mariana that also has the highest family income (SEADE, 2017), when compared to another RCH.

In the peripheric areas of Sao Paulo, the percentages of household recyclable solid waste recovery are low; additionally, in lower income areas, few streets are served by the selective collection services. The Figure 1 shows all of Säo Paulo's RCH and the percentage of recycled waste collected in 2016 where the highest percentage is in the central that are more urbanized areas with better service and infrastructure and a higher family income. 
Sardinia 2017 / Sithenth International Waste Management and Londil Symposium \& 2 - 6 October 2017

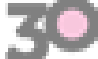

Table 2 Percentage of recycled solid waste from total of household solid waste by RCH in São Paulo, 2006-2016

\begin{tabular}{|c|c|c|c|c|c|c|c|c|c|c|c|}
\hline \multirow{2}{*}{ REGIONAL CITY HALL } & \multicolumn{11}{|c|}{$\%$ RECYCLED SOLID WASTEMUNICIPAL SOLID WASTE } \\
\hline & 2006 & 2007 & 2006 & 2009 & 2010 & 2011 & 2012 & 2013 & 2014 & 2015 & 2016 \\
\hline Aricanduva/Formosa & 0.38 & 0.47 & 0.61 & 0.60 & 0.77 & 0.95 & 1.10 & 1.05 & 4.71 & 1.44 & 1.25 \\
\hline Butanta & 0.72 & 0.94 & 1.07 & 0.74 & 0.61 & 0.86 & 1.23 & 2.18 & 1.95 & 2.05 & 2.28 \\
\hline Campo Limpo & 0.41 & 0.32 & 0.36 & 0.29 & 0.26 & 0.36 & 0.37 & 0.44 & 0.61 & 1.90 & 2.25 \\
\hline Capela Do Socorro & 0.55 & 0.97 & 1.70 & 1.89 & 1.81 & 1.78 & 2.04 & 2.26 & 2.18 & 4.23 & 3.60 \\
\hline Casa Verde & 0.32 & 0.51 & 0.67 & 0.51 & 0.29 & 0.61 & 0.86 & 1.07 & 1.03 & 1.07 & 0.79 \\
\hline Cidade Adernar & 0.25 & 0.41 & 0.48 & 0.42 & 0.53 & 0.63 & 0.67 & 0.69 & 0.78 & 1.62 & 1.90 \\
\hline Cidade Tiradentes & 0.00 & 0.00 & 0.09 & 0.28 & 0.38 & 0.53 & 0.59 & 0.36 & 0.59 & 0.47 & 0.37 \\
\hline Ermelino Matarazzo & 0.00 & 0.00 & 0.00 & 0.00 & 0.00 & 0.00 & 0.31 & 0.30 & 0.37 & 2.51 & 2.93 \\
\hline Freguesia/Brasilandia & 0.51 & 0.47 & 0.62 & 0.53 & 0.34 & 0.51 & 0.62 & 0.66 & 0.68 & 0.83 & 0.81 \\
\hline Guaianases & 0.00 & 0.00 & 0.00 & 0.00 & 0.00 & 0.00 & 0.00 & 0.00 & 0.00 & 0.00 & 0.36 \\
\hline Ipiranga & 0.44 & 0.63 & 1.09 & 1.30 & 1.47 & 2.05 & 2.43 & 2.66 & 2.79 & 3.44 & 3.53 \\
\hline ltaim Paulista & 0.66 & 1.55 & 2.60 & 2.40 & 1.61 & 0.64 & 0.97 & 1.10 & 0.74 & 0.11 & 0.36 \\
\hline liaquera & 0.45 & 0.63 & 0.89 & 0.43 & 0.43 & 0.49 & 0.54 & 0.67 & 0.72 & 0.80 & 0.85 \\
\hline Jabaquara & 0.82 & 1.09 & 1.43 & 1.33 & 1.11 & 1.64 & 1.75 & 2.21 & 2.28 & 3.52 & 3.80 \\
\hline Jacana/Tremembe & 0.28 & 0.45 & 0.56 & 0.30 & 0.50 & 0.42 & 1.04 & 1.28 & 0.32 & 0.62 & 0.58 \\
\hline Lapa & 1.52 & 2.48 & 2.53 & 1.34 & 1.28 & 2.55 & 3.69 & 4.26 & 4.26 & 6.14 & 5.91 \\
\hline Maria/Guiherme & 0.70 & 0.89 & 0.83 & 0.59 & 0.51 & 0.87 & 0.84 & 0.73 & 1.02 & 0.96 & 0.84 \\
\hline Mboi Mirim & 0.00 & 0.00 & 0.00 & 0.00 & 0.00 & 0.00 & 0.00 & 0.00 & 0.05 & 0.0 & 0.18 \\
\hline Mooca & 0.63 & 0.83 & 1.06 & 1.04 & 0.83 & 0.83 & 1.05 & 1.30 & 1.26 & 1.70 & 2.14 \\
\hline Parelheiros & 0.00 & 0.00 & 0.00 & 0.00 & 0.00 & 0.00 & 0.00 & 0.00 & 0.00 & 0.00 & 0.01 \\
\hline Pentha & 0.47 & 0.71 & 1.15 & 0.42 & 0.29 & 0.41 & 0.82 & 0.98 & 0.75 & 1.13 & 1.07 \\
\hline Perus & 0.00 & 0.01 & 0.04 & 0.00 & 0.00 & 0.00 & 0.03 & 0.07 & 0.24 & 0.0 & 0.05 \\
\hline Pinheiros & 1.83 & 2.31 & 2.40 & 2.44 & 2.51 & 3.97 & 4.73 & 5.20 & 5.18 & 6.50 & 5.84 \\
\hline Pirituba/Jaragua & 0.30 & 0.55 & 0.58 & 0.63 & 0.81 & 0.72 & 0.65 & 0.96 & 1.45 & 1.20 & 1.31 \\
\hline Santana/Tucuruvi & 0.78 & 1.12 & 1.68 & 1.31 & 0.88 & 1.57 & 1.57 & 1.50 & 1.47 & 2.35 & 2.91 \\
\hline Santo Amaro & 2.99 & 2.28 & 3.16 & 2.23 & 3.05 & 4.24 & 4.34 & 4.63 & 4.61 & 4.65 & 5.21 \\
\hline Sao Mateus & 0.18 & 0.10 & 0.50 & 0.21 & 0.36 & 0.06 & 0.31 & 0.76 & 0.99 & 0.53 & 1.12 \\
\hline Sao Miguel Paulista & 0.00 & 0.00 & 0.00 & 0.00 & 0.00 & 0.00 & 0.00 & 0.00 & 0.07 & 0.00 & 0.45 \\
\hline Sapopemba & - & $\cdot$ & - & $=$ & $=$ & $=$ & $=$ & 0.74 & 0.76 & 0.92 & 0.88 \\
\hline Se & 1.11 & 1.51 & 2.02 & 2.07 & 2.14 & 2.74 & 2.94 & 3.46 & 3.14 & 3.68 & 3.51 \\
\hline Vila Mariana & 1.87 & 2.67 & 3.77 & 1.82 & 2.79 & 4.96 & 5.32 & 6.74 & 7.11 & 9.69 & 10.06 \\
\hline Vila Prudente & 0.30 & 0.38 & 0.41 & 0.57 & 1.11 & 1.15 & 1.32 & 1.42 & 2.89 & 2.40 & 2.58 \\
\hline
\end{tabular}




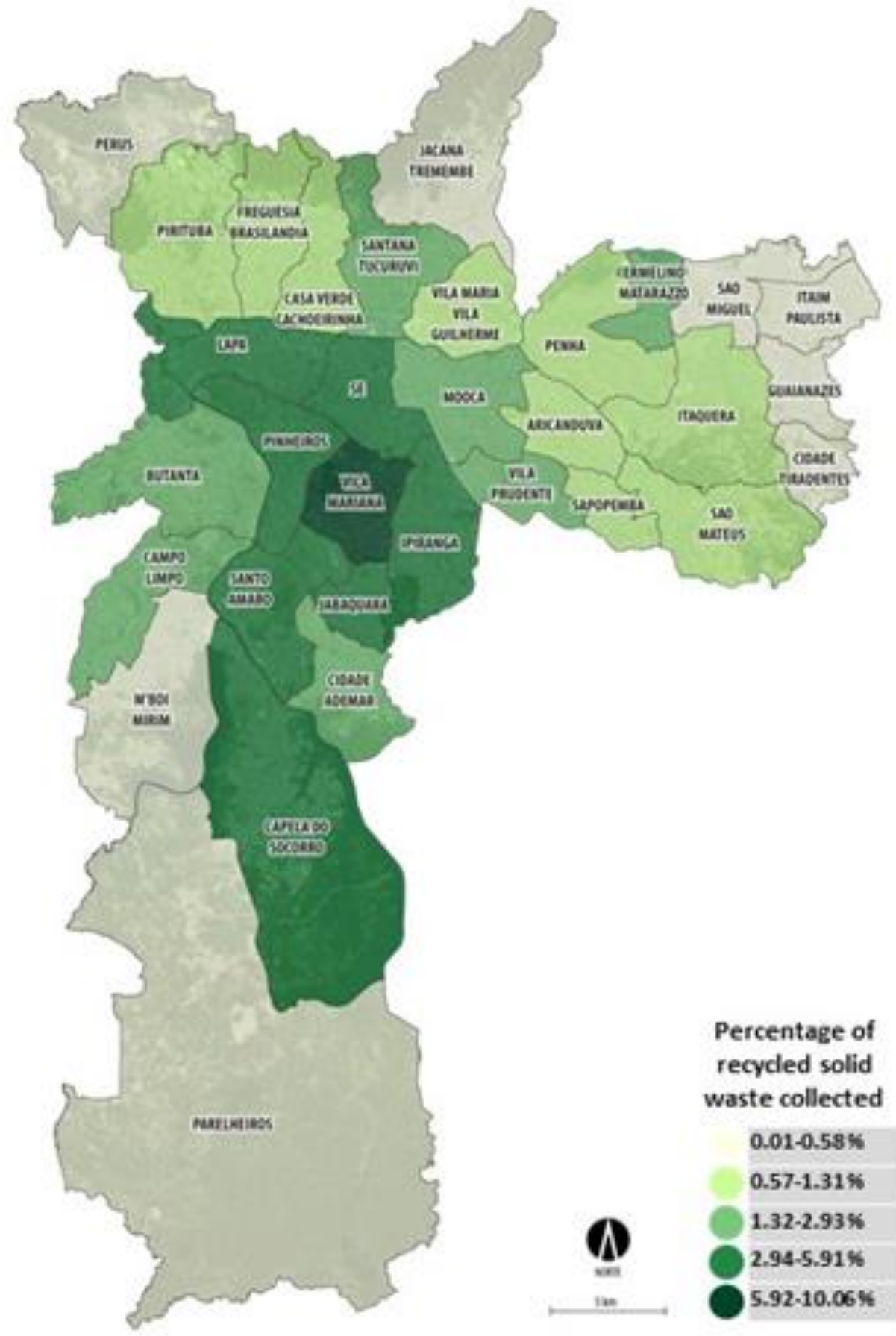

Figure 1 Percentage of recycled solid waste collected in relation to the total collection of household waste by RCH for Säo Paulo in 2016 
The results for RCH show that regions with greater generation of household waste were not necessarily the regions where they have the most significant recycling rates, as presented in Table 3. Therefore, the actions for improving the recycling rates of household dry waste could be: (1) to prioritize the top $10 \mathrm{RCH}$ that generate more recycled household waste to achieve part of the goals of the MSMP and (ii) under the socio-environmental perspective, to carry out actions in the peripheral areas of the city inhabited by families with lower income and areas of environmental protection that are more vulnerable to the impacts of inadequate management of solid wastes.

Table 3 Raking of household waste per RCH, percentage of recycled and income per capita for Sảo Paulo in 2016

\begin{tabular}{|c|c|c|c|c|}
\hline $\begin{array}{l}\text { RANKING } \\
\text { HOUSEHOLD } \\
\text { WASTE }\end{array}$ & $\begin{array}{l}\text { REGIONAL CITY HULL } \\
\text { (RCH) }\end{array}$ & $\begin{array}{c}\text { HOUSEHOLD } \\
2016(t)\end{array}$ & $\begin{array}{l}\% \text { RECYCLED } / \\
\text { HOUSEHOLD }\end{array}$ & $\begin{array}{c}\text { PER CAFITA } \\
\text { INCOME } \\
\text { (BRAZILI/NN } \\
\text { MONEY, } \\
\text { DEMOGRAFIC } \\
\text { CENSUS } \\
2010)\end{array}$ \\
\hline $1^{\circ}$ & SE & $182,152.97$ & $3.51 \%$ & $1,970.05$ \\
\hline $2^{\circ}$ & CAMPO LIMPO & $179,294.39$ & $2.25 \%$ & $1,074.49$ \\
\hline $3^{\circ}$ & CAPELA DO SOCORRO & $173,736.58$ & $3.60 \%$ & $1,001.96$ \\
\hline $4^{\circ}$ & MBOI MIRIM & $159,783.63$ & $0.18 \%$ & 513.30 \\
\hline $5^{\circ}$ & BUTANTA & $157,497.64$ & $2.28 \%$ & $2,018.12$ \\
\hline $6^{\circ}$ & $\mathrm{MOOCA}$ & $152,384.30$ & $2.14 \%$ & $1,442.82$ \\
\hline $7^{\circ}$ & ITAQUERA & $146,374.60$ & $0.85 \%$ & 638.51 \\
\hline $8^{\circ}$ & PENHA & $145,636.97$ & $1.07 \%$ & 861.58 \\
\hline $9^{\circ}$ & IPIRANGA & $143,680.09$ & $3.53 \%$ & $1,309.22$ \\
\hline $10^{\circ}$ & PIRITUBA / JARAGUA & $136,428.00$ & $1.31 \%$ & 818.14 \\
\hline $11^{\circ}$ & PINHEIROS & $134,866.64$ & $5.84 \%$ & $4,138.16$ \\
\hline $12^{\circ}$ & CIDADE ADEMAR & $125,744.80$ & $1.90 \%$ & 586.22 \\
\hline $13^{\circ}$ & FREGUESIAJRASILANDIA & $125,601.50$ & $0.81 \%$ & 739.07 \\
\hline $14^{\circ}$ & SAO MATEUS & $121,900.29$ & $1.12 \%$ & 495.35 \\
\hline $15^{\circ}$ & LAPA & $121,345.01$ & $5.91 \%$ & $2,266.02$ \\
\hline $16^{\circ}$ & VILA MMRIANA & $116,996.51$ & $10.06 \%$ & $3,765.02$ \\
\hline $17^{\circ}$ & MARIA / GUILHERME & $112,868.28$ & $0.84 \%$ & 919.30 \\
\hline $18^{\circ}$ & SANTANA / TUCURUMI & $108,125.06$ & $2.91 \%$ & $1,523.21$ \\
\hline $19^{\circ}$ & CASA VERDE & $103,552.25$ & $0.79 \%$ & 924.84 \\
\hline $20^{\circ}$ & SAO MIGUEL PAULISTA & $98,593.18$ & $0.45 \%$ & 518.81 \\
\hline $21^{\circ}$ & SANTO AMARO & $94,236.07$ & $5.21 \%$ & $2,678.10$ \\
\hline $22^{\circ}$ & ITAIM PAULISTA & $92,125.48$ & $0.36 \%$ & 469.22 \\
\hline $23^{\circ}$ & ARICANDUNAFORMOSA & $90,615.09$ & $1.25 \%$ & $1,248.10$ \\
\hline $24^{\circ}$ & JACANA/TREMEMBE & $89,002.53$ & $0.58 \%$ & 714.05 \\
\hline $25^{\circ}$ & SAPOPEMBA & $81,059.81$ & $0.88 \%$ & Nat available \\
\hline $26^{\circ}$ & VILA PRUDENTE & $71,906.82$ & $2.58 \%$ & 871.17 \\
\hline $27^{\circ}$ & GUAIANASES & $68,505.41$ & $0.36 \%$ & 463.98 \\
\hline $28^{\circ}$ & JABAQUARA & $66,831.84$ & $3.80 \%$ & $1,233.39$ \\
\hline
\end{tabular}




\begin{tabular}{|c|l|l|l|c|}
\hline $\begin{array}{c}\text { RANKING } \\
\text { HOUSEHOLD } \\
\text { WASTE }\end{array}$ & $\begin{array}{c}\text { REGIONAL CITY HALL } \\
\text { (RCH) }\end{array}$ & $\begin{array}{c}\text { HOUSEHOLD } \\
2016(t)\end{array}$ & $\begin{array}{c}\text { PER CAPITA } \\
\text { INCOME RECYCLED / } \\
\text { HOUSEHOLD } \\
\text { (BRAZILI/N } \\
\text { MONEY, } \\
\text { DEMOGRAFIC } \\
\text { CENSUS } \\
2010)\end{array}$ \\
\hline $29^{\circ}$ & ERMELINO MATARMZZO & $61,524.49$ & $2.93 \%$ & 703.39 \\
\hline $30^{\circ}$ & PERUS & $44,617.21$ & $0.05 \%$ & 500.67 \\
\hline $31^{\circ}$ & CIDADE TIRMDENTES & $43,307.12$ & $0.37 \%$ & 407.03 \\
\hline $32^{\circ}$ & PARELHEIROS & $36,187.40$ & $0.01 \%$ & 375.78 \\
\hline
\end{tabular}

\section{CONCLUSIONS}

To conclude, these first results show that São Paulo's City Hall has not reached the goals of the Municipal Solid Waste Integrated Plan (MSWP) to collect and process 3,000 tons/day of dry waste and 1,300 tons/day for organic. The selective collection for dry waste isn't available for the whole territory.

To achieve recycling targets, it will be necessary to focus on the actions of social mobilization for the segregation of waste at the source in the regions that produce the higher volumes of household waste (top 10 regional city hall from Table 3 ) and peripheral regions that include areas of environmental protection. Also, it will be necessary to strengthen the associations and cooperatives of waste pickers and implan more central mechanized waste, as planned.

\section{ACNOWLEDGEMENTS}

Acknowledgments to: The Municipal Authority Urban Clearing (MAUC) of São Paulo that provided the quantitative data of solid residues and The Global Health and Sustainability Program of Faculty of Public Health from Sao Paulo University (USP) for the opportunity of conducting this research.

\section{REFERENCES}

Instituto Brasileiro de Geografia e Estatística. IBGE. Cidades. Available in: < http://cidades.ibge.gov.br/xtras/perfil.php?codmun=355030>. Accessed: 01/01/2017

Prefeitura Municipal de Sảo Paulo. AMLURB. Plano de Gestăo Integrada de Resíduos Sólidos da Cidade de Sảo Paulo. Säo Paulo, 2014.

Fundaçảo Sistema Estadual de Análise de Dados. SEADE. Informaçōes dos Municípios Paulistas para 2010. Available in:shttp://www.imp.seade.gov.brifrontend/\#tabelas》. Accessed: 02/22/17

Ministério das Cidades/Secretaria Nacional de Saneamento Ambiental. Diagnóstico do Manejo de Residuos Sólidos Urbanos - 2015. Sistema Nacional de Informaçŏes sobre Saneamento - SNIS. Available in: «http://www.snis.gov.br/diagnostico-residuos-solidos> Aocessed: 04/30/17

UN HABITAT. Solid Waste management in the wordls's cities. Water and Sanitation in the 
Sardinia 2017 / Stateenth Inbernational Waste Management and Londil Symposlum / 2 - 6 October 2017

World's cities 2010. Available in < https:/unhabitat.org/books/solid-waste-management-inthe-worlds-cities-water-and-sanitation-in-the-worlds-cities-2010-2/> Acessed: Accessed: $02 / 15 / 17$

FOR JOURNAL TITLE ABBREVIATIONS SEE:

hatp://www.efm.leeds.ac.ulv/markisiabbriA abrvithtml 
11 ANEXOS 
11.1 CARACTERIZAÇÃO GRAVIMÉTRICA DOS RESÍDUOS EM SÃO PAULO 
CARACTERIZAÇÃO DOS RESÍDUOS SÓLIDOS DOMICILIARES DO MUNICÍPIO DE SÃO PAULO. AGRUPAMENTO SUDESTE. PRIMEIRO QUADRIMESTRE 2015.

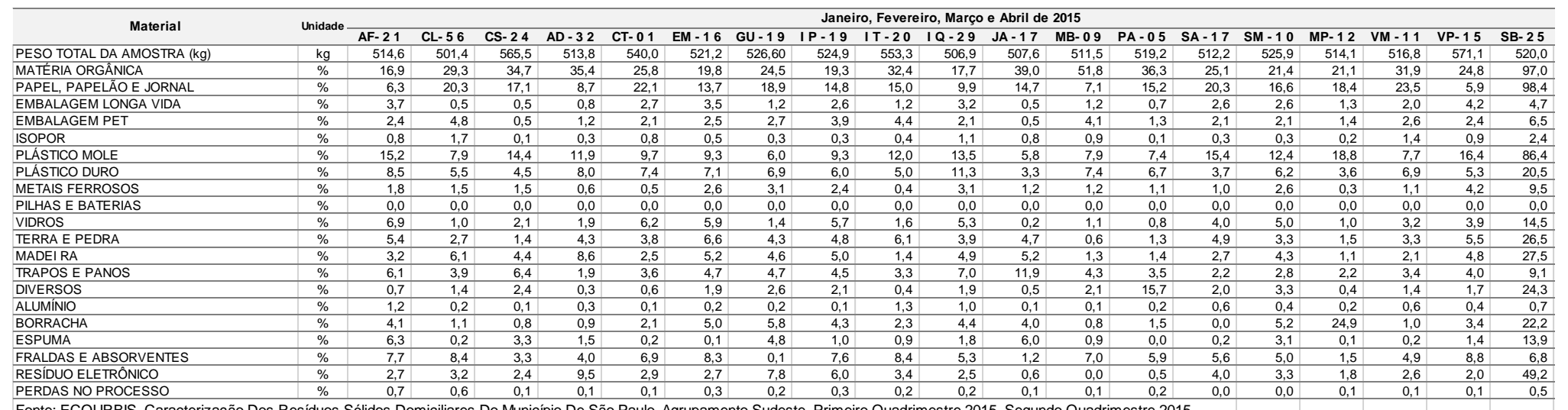

Fonte: ECOURBIS. Caracterização Dos Resíduos Sólidos Domicilires Do Município De São Paulo. Agrupamento Sudeste. Primeiro Qudrimestre 2015 Segundo Quadrimestre 2015

Adaptado

\begin{tabular}{|l|c|l|c|}
\hline Prefeitura Regional & Sigla Amostra & Prefeitura Regional & Sigla Amostra \\
\hline Aricanduva/Formosa & AF-21 & Jabaquara & JA-03 \\
\hline Campo Limpo & CL-42 & M Boi Mirim & MB-53 \\
\hline Socorro & CS-43 & Parelheiros & PA-17 \\
\hline Cidade Ademar & AD-13 & Santo Amaro & SA-04 \\
\hline Cidade Tirandentes & CT-15 & São Mateus & SM-40 \\
\hline Ermelino Matarazzo & EM-04 & São Miguel & MP-29 \\
\hline Guaianazes & GU-21 & Vila Mariana & VM-15 \\
\hline Ipiranga & IP-29 & Vila Prudente & VP-08 \\
\hline Ittaim Paulista & T-12 & Sapopemba & SB-14 \\
\hline thaquera & IQ-32 & &
\end{tabular}


CARACTERIZAÇÃO DOS RESÍDUOS SÓLIDOS DOMICILIARES DO MUNICÍPIO DE SÃO PAULO. AGRUPAMENTO SUDESTE. SEGUNDO QUADRIMESTRE 2015

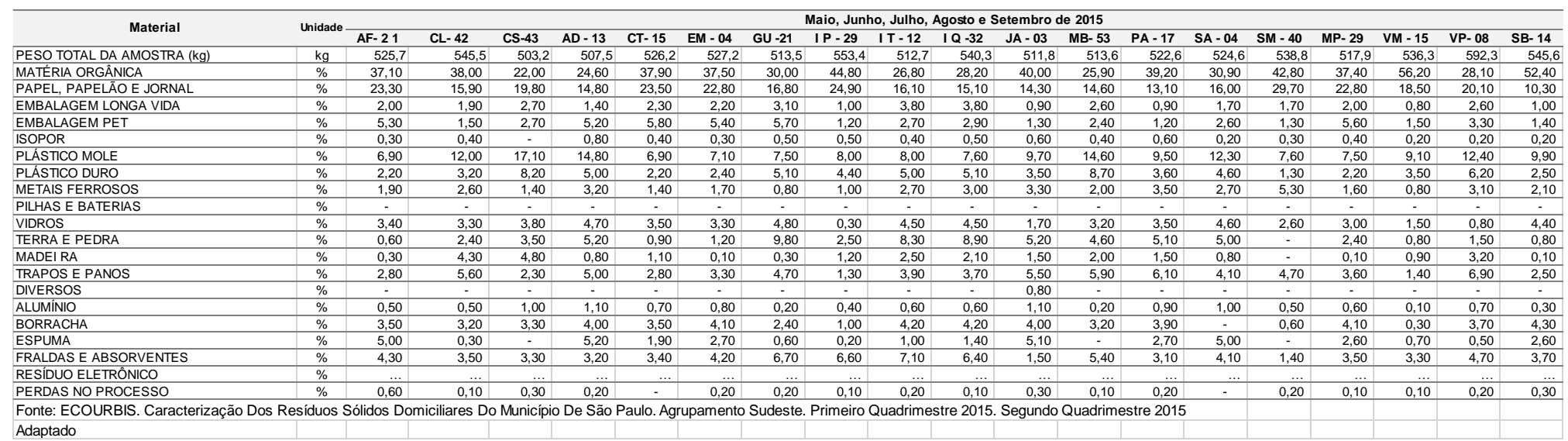

\begin{tabular}{|l|c|l|c|}
\hline Prefeitura Regional & Sigla Amostra & Prefeitura Regional & Sigla Amostra \\
\hline Aricanduva/Formosa & AF-21 & Jabaquara & JA-03 \\
\hline Campo Limpo & CL-42 & M' Boi Mirim & MB-53 \\
\hline Socorro & CS-43 & Parelheiros & PA-17 \\
\hline Cidade Ademar & AD-13 & Santo Amaro & SA-04 \\
\hline Cidade Tirandentes & CT-15 & São Mateus & SM-40 \\
\hline Ermelino Matarazzo & EM-04 & São Miguel & MP-29 \\
\hline Guaianazes & GU-21 & Vila Mariana & VM-15 \\
\hline Ipiranga & IP-29 & Vila Prudente & VP-08 \\
\hline Itaim Paulista & ח-12 & Sapopemba & SB-14 \\
\hline Itaquera & QQ-32 & & \\
\end{tabular}


CARACTERIZAÇÃO DOS RESÍDUOS SÓLIDOS DOMICILIARES DO MUNICÍPIO DE SÃO PAULO. AGRUPAMENTO NOROESTE. MARCO A JUNHO DE 2015.

\begin{tabular}{|c|c|c|c|c|c|c|c|c|c|c|c|c|c|c|}
\hline \multirow{2}{*}{ Material } & \multirow{2}{*}{ Unidade } & \multicolumn{13}{|c|}{ Março, Abril, Maio e Junho 2015} \\
\hline & & BT 19 & CV 13 & FB 12 & JT 23 & LA 01 & MG 29 & MO 32 & PE 17 & PI 08 & PJ 28 & PR 06 & SE 23 & ST 24 \\
\hline total de amostra & $\%$ & 100,00 & 100,00 & 100,00 & 100,00 & 100,00 & 100,00 & 100,00 & 100,00 & 100,00 & 100,00 & 100,00 & 100,00 & 100,00 \\
\hline Matéria Orgânica & $\%$ & 52,62 & 50,25 & 46,04 & 46,85 & 53,39 & 51,27 & 48,37 & 45,95 & 51,53 & 49,06 & 48,32 & 48,26 & 50,11 \\
\hline Papel, Papelão e Jornal & $\%$ & 10,49 & 13,86 & 14,40 & 13,32 & 11,66 & 2,89 & 10,65 & 11,80 & 7,72 & 9,31 & 10,19 & 12,46 & 13,78 \\
\hline Embalagem longa vida & $\%$ & 0,99 & 0,90 & 0,59 & 0,27 & 0,63 & 0,41 & 0,63 & 0,45 & 0,18 & 0,31 & 0,82 & 0,14 & 0,59 \\
\hline Embalagem Pet & $\%$ & 1,34 & 0,58 & 0,81 & 0,99 & 0,45 & 0,45 & 0,27 & 0,36 & 0,22 & 0,36 & 0,91 & 1,04 & 0,41 \\
\hline Isopor \% & $\%$ & 0,27 & 0,13 & 0,14 & 0,32 & 0,54 & 0,14 & 0,23 & 0,09 & 0,40 & 0,18 & 0,23 & 0,14 & 0,14 \\
\hline Plástico Mole & $\%$ & 8,65 & 10,39 & 8,64 & 11,84 & 10,17 & 8,00 & 14,19 & 12,03 & 10,41 & 10,61 & 15,53 & 8,44 & 13,60 \\
\hline Plástico Duro & $\%$ & 1,34 & 1,62 & 1,85 & 2,12 & 6,83 & 1,67 & 4,08 & 0,63 & 0,94 & 3,73 & 3,26 & 0,81 & 1,49 \\
\hline Metais ferrosos & $\%$ & - & 0,49 & 0,77 & 3,24 & - & 0,95 & - & 1,17 & 2,47 & 1,03 & 1,68 & 0,23 & 1,04 \\
\hline Pilhas e Baterias & $\%$ & - & - & - & - & - & - & - & - & - & - & - & - & - \\
\hline Vidros & $\%$ & - & 1,44 & 4,01 & 2,88 & 3,30 & 3,53 & 5,71 & 3,78 & 3,01 & 2,16 & 0,82 & 2,57 & 1,76 \\
\hline Terra e Pedra & $\%$ & - & - & 1,67 & 5,49 & - & - & - & - & - & - & - & 2,17 & - \\
\hline Madeira & $\%$ & 4,12 & - & 0,86 & - & - & - & - & - & 0,99 & - & - & - & 2,34 \\
\hline Trapos e panos & $\%$ & 1,48 & 2,20 & 7,65 & 3,33 & 2,40 & 14,69 & 0,59 & - & 3,73 & 1,71 & 2,36 & 8,08 & 1,71 \\
\hline Diversos & $\%$ & 6,86 & 3,10 & 1,35 & 2,93 & - & - & - & 5,00 & 4,80 & 7,69 & - & - & 1,40 \\
\hline Alumínio & $\%$ & 0,40 & 0,49 & 0,27 & - & 0,27 & 0,14 & 0,18 & 0,18 & 0,36 & 0,27 & - & 0,27 & 0,36 \\
\hline Borracha & $\%$ & - & - & - & - & - & - & - & 2,61 & - & - & - & - & - \\
\hline Fraldas/Papel Higiênico & $\%$ & 10,80 & 14,13 & 10,40 & 6,17 & 9,76 & 13,16 & 14,55 & 15,32 & 12,61 & 9,44 & 15,22 & 12,78 & 9,50 \\
\hline Espuma & $\%$ & - & - & - & - & - & 2,12 & - & - & - & 3,64 & - & 1,99 & - \\
\hline Lixo Eletrônico & $\%$ & - & - & - & - & - & - & - & - & - & - & 0,18 & - & 1,22 \\
\hline Perdas no Processo & $\%$ & 0,63 & 0,40 & 0,59 & 0,27 & 0,59 & 0,59 & 0,54 & 0,63 & 0,63 & 0,49 & 0,50 & 0,63 & 0,59 \\
\hline
\end{tabular}

Fonte: LOGA. Relatório De Caracterização Dos Resíduos Sólidos Domiciliares Do Município De São Paulo. Agrupamento Noroeste.

Adaptado

\begin{tabular}{|l|c|l|c|}
\hline Prefeitura Regional & Sigla & Prefeitura Regional & Sigla \\
\hline Butantä & $\mathrm{BT}$ & Perus & $\mathrm{PR}$ \\
\hline Casa Verde/Cachoeirinha & $\mathrm{CV}$ & Pinheiros & $\mathrm{PI}$ \\
\hline Freguesia/Brasilândia & $\mathrm{FB}$ & Pirituba & $\mathrm{PJ}$ \\
\hline Jaçană/Tremembé & JT & Santaca/Tucuruvi & $\mathrm{ST}$ \\
\hline Lapa & LA & Sé & SE \\
\hline Mooca & MO & Vila Maria/Vila Guilherme & MG \\
\hline Penha & $\mathrm{PE}$ & & \\
\hline
\end{tabular}


CARACTERIZAÇÃO DOS RESÍDUOS SÓLIDOS DOMICILIARES DO MUNICÍPIO DE SÃO PAULO. AGRUPAMENTO NOROESTE. JULHO A OUTUBRO DE 2015.

\begin{tabular}{|c|c|c|c|c|c|c|c|c|c|c|c|c|c|c|}
\hline \multirow{2}{*}{ Material } & \multirow{2}{*}{ Unidade } & \multicolumn{13}{|c|}{ Julho, Agosto, Setembro e Outurbro 2015} \\
\hline & & BT 32 & CV 16 & FB 29 & JT 28 & LA 21 & MG07 & MO 17 & PE 10 & PI11 & PJ 17 & PR 11 & SE 11 & ST 29 \\
\hline total de amostra & $\%$ & 100,00 & 100,00 & 100,00 & 100,00 & 100,00 & 100,00 & 100,00 & 100,00 & 100,00 & 100,00 & 100,00 & 100,00 & 100,00 \\
\hline Matéria Orgânica & $\%$ & 47,38 & 47,30 & 44,30 & 43,91 & 50,11 & 45,75 & 53,94 & 49,77 & 46,69 & 46,35 & 49,32 & 47,94 & 45,96 \\
\hline Papel, Papelão e Jornal & $\%$ & 12,92 & 6,24 & 12,01 & 11,86 & 11,77 & 12,22 & 8,69 & 8,11 & 10,58 & 7,40 & 7,01 & 14,93 & 10,87 \\
\hline Embalagem longa vida & $\%$ & 1,22 & 1,03 & 0,54 & 0,72 & 0,68 & 0,36 & 0,41 & 0,41 & 0,77 & 0,59 & 0,59 & 0,36 & 0,55 \\
\hline Embalagem Pet & $\%$ & 0,50 & 0,67 & 0,22 & 0,14 & 1,27 & 0,22 & 0,50 & 0,45 & 0,41 & 0,46 & 0,59 & 0,36 & 0,55 \\
\hline Isopor \% & $\%$ & 0,14 & 0,04 & 0,18 & 0,18 & 0,54 & 0,13 & 0,36 & 0,23 & 0,09 & 0,41 & 0,14 & 0,27 & 0,18 \\
\hline Plástico Mole & $\%$ & 10,30 & 12,58 & 12,68 & 14,65 & 10,86 & 13,93 & 11,00 & 9,64 & 12,88 & 12,01 & 16,06 & 11,99 & 11,65 \\
\hline Plástico Duro & $\%$ & 2,12 & 0,54 & 1,71 & 2,21 & 1,49 & 1,98 & 4,71 & 5,63 & 3,42 & 5,02 & 3,59 & 2,71 & 1,51 \\
\hline Metais ferrosos & $\%$ & 1,36 & - & 0,63 & 0,68 & 0,77 & 0,54 & - & 3,06 & - & 2,10 & - & 1,00 & 0,50 \\
\hline Pilhas e Baterias & $\%$ & - & - & - & - & - & - & - & - & - & - & - & - & - \\
\hline Vidros & $\%$ & 1,81 & 1,93 & 5,17 & 1,40 & 4,62 & 4,36 & 0,41 & - & 2,66 & 0,18 & 2,00 & 0,95 & 1,83 \\
\hline Terra e Pedra & $\%$ & - & - & 1,08 & - & - & - & - & - & - & - & - & - & 2,79 \\
\hline Madeira & $\%$ & - & - & 2,88 & 1,04 & 1,36 & - & - & - & 2,93 & - & - & - & - \\
\hline Trapos e panos & $\%$ & - & 15,00 & 9,08 & 10,96 & 2,44 & 0,94 & 4,93 & 3,92 & - & 5,57 & 6,19 & 2,40 & 6,62 \\
\hline Diversos & $\%$ & 10,03 & - & 4,54 & - & 0,86 & 3,87 & 1,13 & 5,09 & 9,05 & 2,28 & 0,23 & - & 2,56 \\
\hline Alumínio & $\%$ & 0,14 & - & 0,18 & 0,23 & 0,68 & 0,13 & 0,86 & 0,32 & - & 0,14 & - & 0,14 & 0,59 \\
\hline Borracha & $\%$ & - & - & - & 1,58 & - & - & - & - & - & - & - & - & - \\
\hline Fraldas/Papel Higiênico & $\%$ & 11,61 & 13,88 & 4,09 & 8,93 & 11,95 & 14,56 & 12,49 & 11,98 & 8,73 & 14,16 & 13,65 & 16,33 & 9,68 \\
\hline Espuma & $\%$ & - & - & - & - & - & - & - & 0,68 & 1,13 & 2,83 & - & - & 1,55 \\
\hline Lixo Eletrônico & $\%$ & - & - & - & 0,99 & - & - & - & - & - & - & - & - & 2,15 \\
\hline Perdas no Processo & $\%$ & 0,50 & 0,76 & 0,70 & 0,54 & 0,59 & 0,99 & 0,59 & 0,72 & 0,68 & 0,50 & 0,64 & 0,63 & 0,46 \\
\hline
\end{tabular}

Fonte: LOGA. Relatório De Caracterização Dos Resíduos Sólidos Domiciliares Do Município De São Paulo. Agrupamento Noroeste.

Adaptado

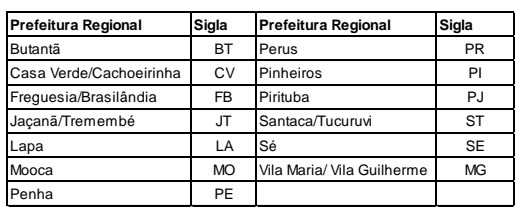




\subsection{CURRÍCULO LATTES}




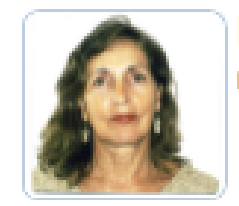

\section{Helena Ribeiro}

Bolsista de Produtividade em Pesquisa do CNPq - Nivel $1 \mathrm{~A}$

Endereg para scessar este CV: http://attes.cnpq.tr/3725809744997200

Última atualizaço do curriculo em 27/04/2018

bachelor's at Geography from Pontificia Universidade Católica de São Paulo (1972), master's at Geography from University of California Berkeley (1981) and doctorate at Physical Geography from Universidade de Säo Paulo (1988). Has experience in Geosciences, focusing on Geographical Climatology, acting on the following subjects: environmental health. urban health, medical geography, air pollution, climate changes and environmental education. Professor of the Environmental Health Department of the School of Public Health of the University of São Paulo. Former professor of Pontificia Universidade Católica de São Paulo. Former Environmental advisor to the Mayor of São Paulo Former Member of the Executive Commitee of ICLEI - International Council for Local Environmental Initiatives. (Texto informado pelo autor)

Identificação

\begin{tabular}{ll}
\hline Nome & Helena Rbeiro \\
Nome em citaçöes bibliogrăficas & RIBEIRO, H.;Ribeiro, Helena
\end{tabular}

Endereço

Endereço Profissional Universidade de Sł̆o Paulo, Facullade de Saúde Púbíca, Departamento de Saúde Ambiental Av. Dr. Arnaldo, 715

Cerqueira César

01246904 - Säo Paulo, SP - Brasil

Telefone: (11) 30667712

Ramal: 218

Fax: (11) 30667732

URL da Homepage: www.fsp. usp.br

Formação acadêmica/titulação

1984 - 1988 Doutorado em Gecgrafla (Geografla Fisica) (Concelto CAPES 5).

Universidade de S\$o Paulo, USP, Brasil.

Thulo: Poluicho do ar e doenças respiratúrias en criança da Grande Sşo Paulo: um estudo de geografla médica, Ano de obtençăo: 1988.

Orientador: José Roberto Tarfa.

$1977-1981$

Bolsista do(a): Cocrdenaçăo de Aperfelçamento de Pesscal de Nivel Superior, CAPES, Brasi. Mestrado en Geografia.

University of Calfornia Berkeley, UCB, Estados Unidos.

Thulo: Sequent land use and envirommental lssues in a subtropical milleu: the case of Stro

Simaro, in the State of Ş̄o paulo, Brazil,Ano de Outençăo: 1981.

Orientador: Higard OReily Sternberg.

Palavras-chave: agricutura sustentável; Cobertura Vegetal; Degradacao Ambiental.

$1969-1972$

Grande área: Clềncias Humanas

Graduaçăo em Geografla.

Pontificla Universidade Católica de Säo Paula, PUC/SP, Brasi.

Pós-doutorado e Livre-docência

1996

$1994-1994$
Livre-docência.

Universidade de Säo Paulo, USP, Brasil.

Thulo: Itha de calor na cidade de Säo Paulo: sua dinâmica e efeltos na saúde đa populaçăo, Ano de obtença: 1996.

Palavras-chave: poluiçơo térmica saúde sło paulo calor.

Grande área: Clências Humanas 